\title{
Investigation of Sand Boils near Ware, IL, Middle Mississippi River, Preston Levee District
}

Julie R. Kelley, Kevin B. Parkman, Ryan C. Strange,

July 2019

Benjamin R. Breland, Joseph B. Dunbar,

and Maureen K. Corcoran

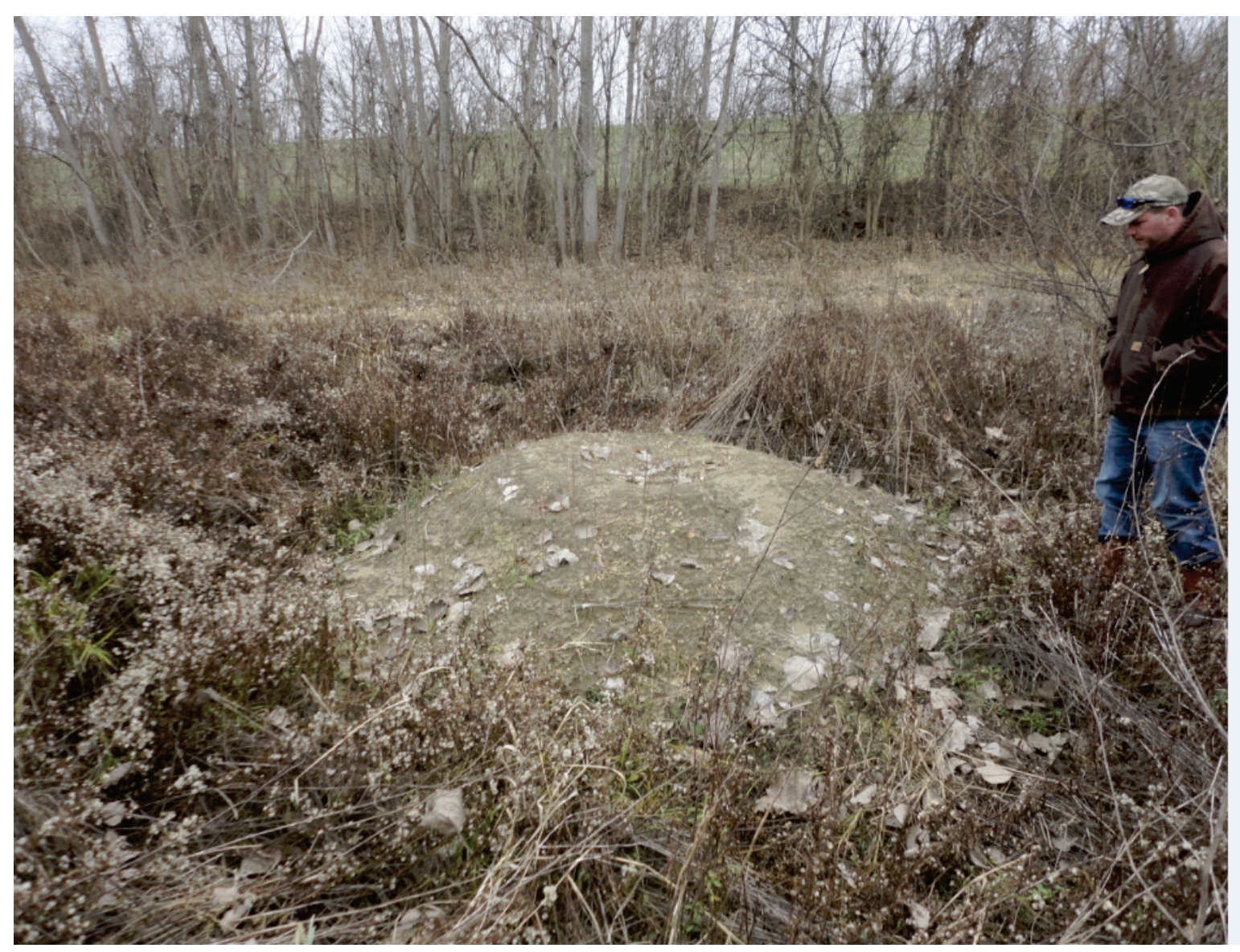


The U.S. Army Engineer Research and Development Center (ERDC) solves the nation's toughest engineering and environmental challenges. ERDC develops innovative solutions in civil and military engineering, geospatial sciences, water resources, and environmental sciences for the Army, the Department of Defense, civilian agencies, and our nation's public good. Find out more at www.erdc.usace.army.mil.

To search for other technical reports published by ERDC, visit the ERDC online library at http://acwc.sdp.sirsi.net/client/default. 


\section{Investigation of Sand Boils near Ware, IL, Middle Mississippi River, Preston Levee District}

Julie R. Kelley, Kevin B. Parkman, Ryan C. Strange, Benjamin R. Breland, Joseph B. Dunbar, and Maureen K. Corcoran

Geotechnical and Structures Laboratory

U.S. Army Engineer Research and Development Center 3909 Halls Ferry Road

Vicksburg, MS 39180-6199

Final report

Approved for public release; distribution is unlimited.

Prepared for U.S. Army Corps of Engineers

Washington, DC 20314-1000

Under Flood and Coastal Storm Damage Reduction Program, Work Unit 4J213B 


\section{Abstract}

During flooding in 2011, 2013, and 2016 on the Middle Mississippi River between St. Louis and Cape Girardeau, MO, high-energy sand boils developed at the land side levee toe. These recent floods varied from moderate to major events but were well below the design flow line for the levees. This report documents a case study of internal erosion at a levee site in southern Illinois near the town of Ware, which is located in the Preston Drainage and Levee District. Site specific geotechnical data from the Ware site were used to identify parameters, such as top stratum thickness, Unified Soil Classification System (USCS) soil types, engineering properties, geologic depositional environments, stratigraphy, and hydraulic gradients, that influence seepage and poor levee performance. An underlying assumption for this study was that sand boils discovered at the Ware site after the flooding in 2013 were formed during a single flood event. However, sand boils are typically associated with chronic seepage related to underlying site geology, levee orientation with the geology, and blocked exit conditions. Thus, seepage problems tend to progress over time in terms of their severity and response to medium to large flood events.

DISCLAIMER: The contents of this report are not to be used for advertising, publication, or promotional purposes. Citation of trade names does not constitute an official endorsement or approval of the use of such commercial products. All product names and trademarks cited are the property of their respective owners. The findings of this report are not to be construed as an official Department of the Army position unless so designated by other authorized documents. 


\section{Contents}

Abstract................................................................................................................................... ii

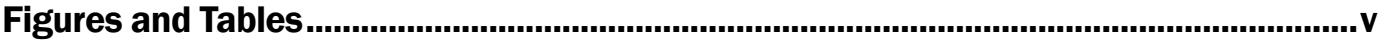

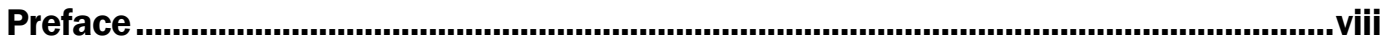

Unit Conversion Factors....................................................................................... ix

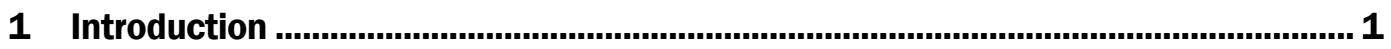

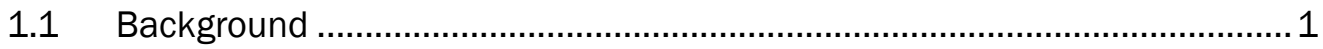

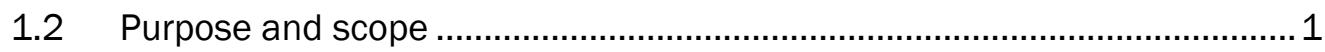

1.3 Preston study site near Ware, IL ....................................................... 2

1.4 General mechanics of sand boils......................................................... 4

1.5 Focus of case history studies .............................................................. 6

1.6 Units of measures used in this report .................................................. 6

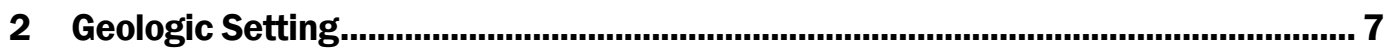

2.1 Previous geologic studies ..................................................................... 7

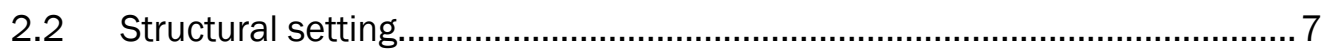

2.3 Holocene depositional environments ................................................. 8

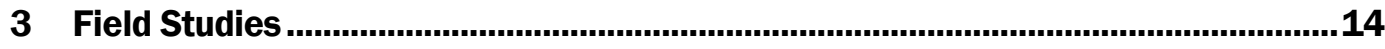

3.1 Approach .......................................................................................... 14

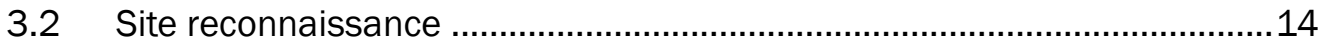

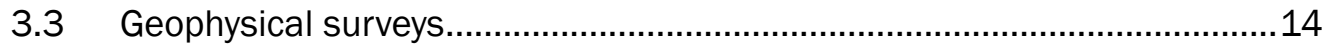

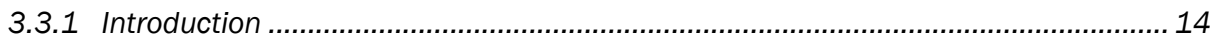

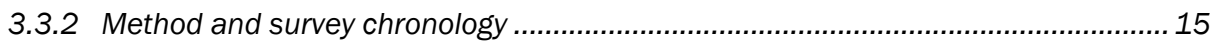

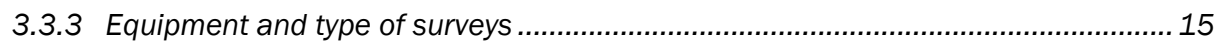

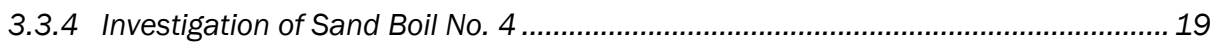

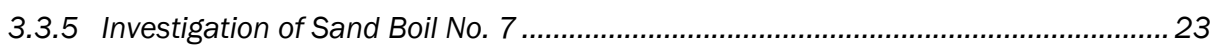

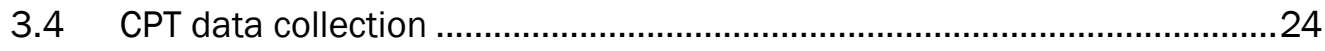

S.5 Sand boil properties.......................................................................... 25

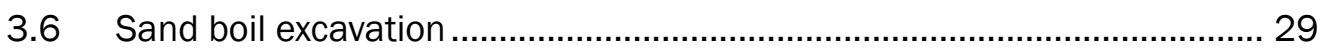

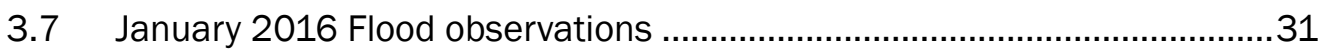

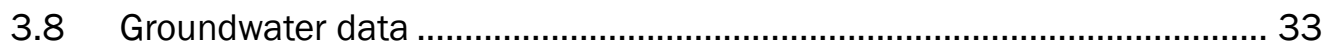

3.9 Comparison of the 2016 and 1993 floods......................................... 34

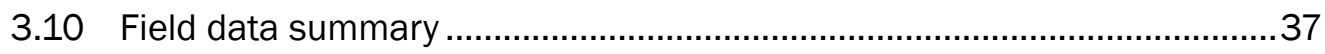

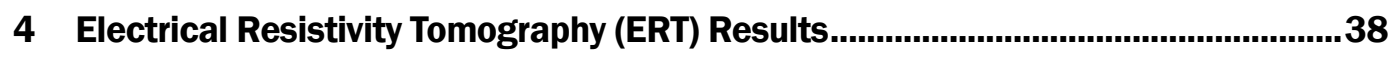

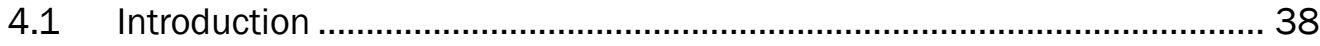

4.2 ERT modeling software and results .................................................. 38

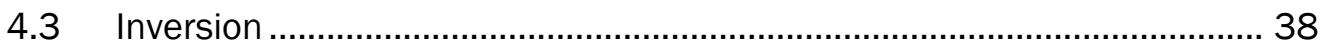

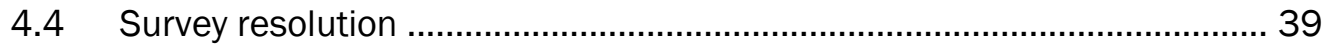

4.5 Depth penetration ...................................................................... 39 
4.6 ERT data and presentation of resistivity sections................................... 40

4.7 Sand Boil No. 4 ................................................................................ 42

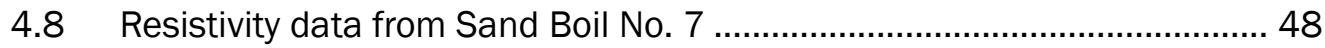

4.9 Summary ................................................................................... 50

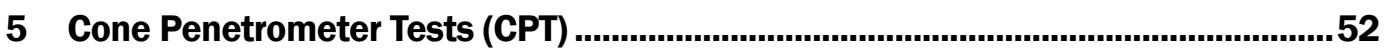

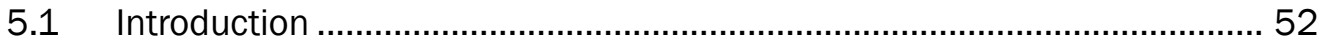

5.2 Blanket thickness and top stratum elevation ...................................... 52

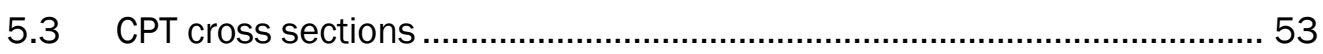

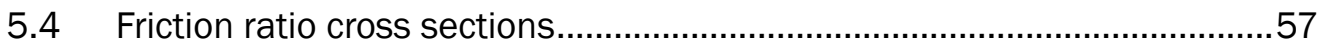

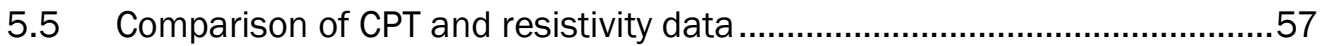

5.6 Laboratory classification of sand boil ejecta and blanket.......................... 62

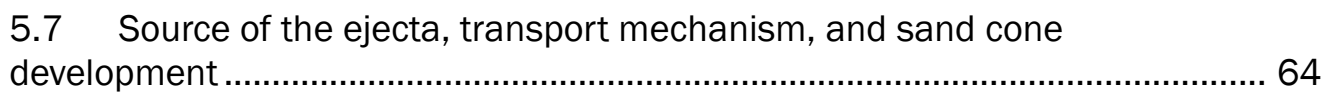

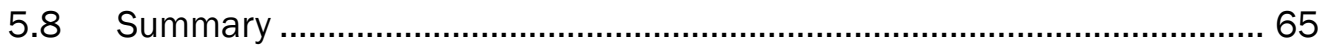

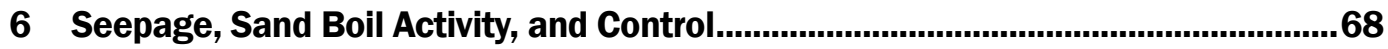

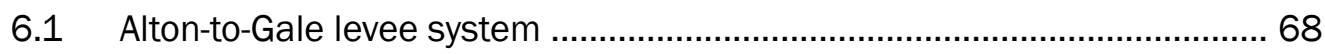

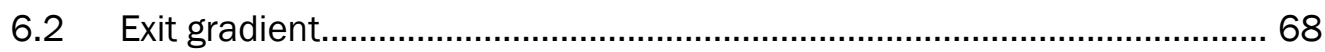

6.3 Exit gradient and critical gradient related to sand boil activity ..................69 69

6.4 USACE seepage criteria ................................................................... 70

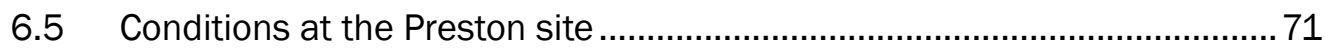

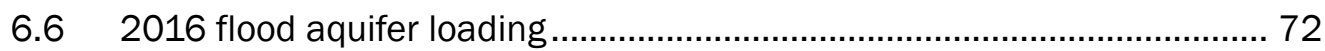

6.72016 exit gradient at Preston .................................................................. 73

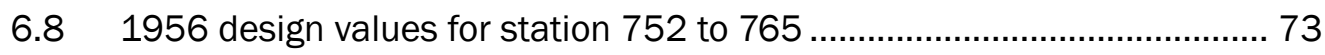

6.92013 exit gradient conditions ................................................................. 74

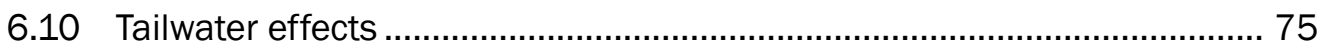

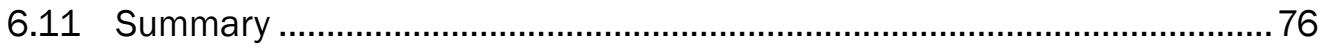

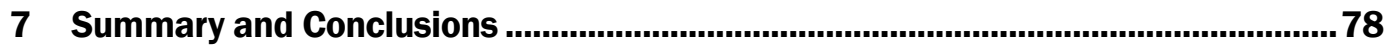

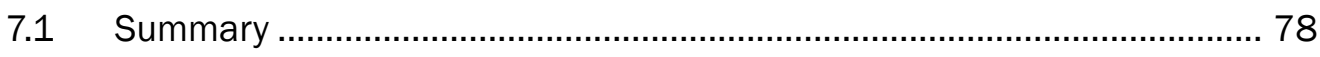

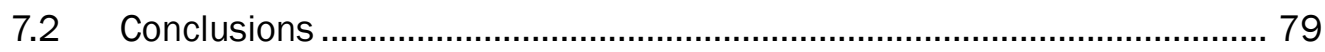

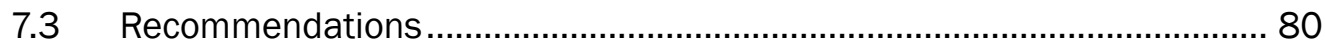

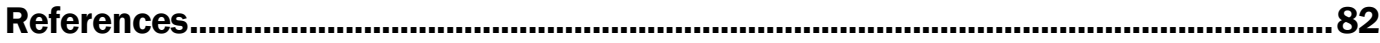

Appendix A: Soil Curves from Ejecta Samples from Sand Boil Cones ...........................84

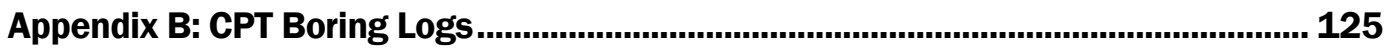

Appendix C: Boring Logs for Split Spoon Samples ................................................. 150

Appendix D: Soil Curves from Split Spoon Samples ................................................ 155

Report Documentation Page 


\section{Figures and Tables}

\section{Figures}

Figure 1. Location of study site in southern Illinois........................................................... 1

Figure 2. Location of the Preston site............................................................................ 3

Figure 3. Ejecta cone observed by a large sand boil in 2014 at Preston study

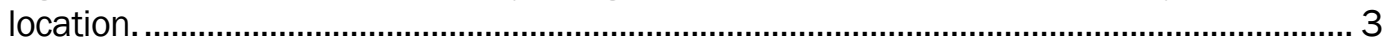

Figure 4. Big Five Levee System protecting the east bank of the Mississippi River. ........... 5

Figure 5. Location of Preston in relation to regional structural features (after Frankie et al. 2008).............................................................................................................. 8

Figure 6. Surface geology map of the Preston levee area showing depositional environments (Woerner et al. 2003).

Figure 7. Geologic cross section from the Preston Levee District reach.............................. 10

Figure 8. Topographic profile across the Preston sand boil area derived from a 5-m Digital Elevation Model (DEM).

Figure 9. Abrupt horizontal changes in particle size at boundaries of swales can concentrate underseepage in the aquifer and promote formation of sand boils. Open borrow pits or presence of deep channels on riverside of levee shorten the seepage path and increase the gradient (USACE 1956a, 1956b).................................... 12

Figure 10. Locations of eight flagged sand boils at Preston............................................. 15

Figure 11. Select sand boil locations at the Preston site. Stars denote the location of sand boils.

Figure 12. View looking northeast. AGI SuperSting system in operation over SB07 at Preston site. Electrode spacing of $0.8 \mathrm{~m}$. ................................................................ 17

Figure 13. View of AGI SuperSting power source, command box, and switch box............ 17

Figure 14. View of ERT survey set up crossing SB-04.................................................... 18

Figure 15. Location of different ERT surveys performed at the Preston site. ..................... 19

Figure 16. Close-up view of fine survey grid conducted over SB-04. ................................. 20

Figure 17. View of 66.4-m- (217.8-ft-) long survey perpendicular to and centered on SB-04.

Figure 18. View of parallel survey with electrode spacing of $0.3 \mathrm{~m}(1 \mathrm{ft})$ and survey length of $29.4 \mathrm{~m}(81.7 \mathrm{ft})$ on SB-04.

Figure 19. View of survey with electrode spacing of $0.8 \mathrm{~m}(2.6 \mathrm{ft})$ and survey length of $66.4 \mathrm{~m}$ (217.8 ft) for SB-04.

Figure 20. Additional oblique survey (white line) conducted within the grid fine (0.3-m [1-ft] electrode spacing) area and across the sand boil.

Figure 21. View of short survey (shown in white) over SB7. Electrode spacing of

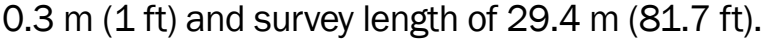

Figure 22. Two long surveys (shown in white) conducted over SB-07, each using an electrode spacing of $0.8 \mathrm{~m}$, resulting in a survey length of $66.4 \mathrm{~m}(217.8 \mathrm{ft})$...

Figure 23. CPT locations (red), ERT lines (blue) and sand boil locations (yellow)...............26

Figure 24. Researchers grouted all boreholes before leaving the study site. 
Figure 25. Sand boils in the sampling area.

Figure 26. SB-01 was excavated to reveal two "necks" where sand had erupted through the dark wetland soil below.

Figure 27. Irregular masses formed in the subsurface as the sand moved upward.

Figure 28. Soil in the trench wall of the sand boil is laminated.

Figure 29. View of low-lying sand boil area behind the levee during the January 2016 Flood.

Figure 30. Pumping of water to the Preston sand boil area to raise the tailwater (see Figure 29)

Figure 31. Piezometer at levee crest with automated water level recorder that measured groundwater levels during the 2016 Flood.

Figure 32. Graph of river stage and groundwater levels from November 2014 through the January 2016 Flood. (Piezometer data courtesy of Jeremy Eck, USACE St. Louis District, Dam and Levee Section).

Figure 33. Comparison of the 2016 Flood to past floods and design flood (USACE 1994).

Figure 34b. Long ERT survey over SB-04

Figure 35. September 2014 location of short-line surveys (0.3-m [1-ft] electrode spacing) at SB-04. Line 1 is farthest to the right (southeast) and line 5 is farthest to the left (northwest)

Figure 36. September 2014 short-line middle resistivity section crossing SB-04 in Figure 35

Figure 37. September 2014 northwestern-most short-line ERT section, adjacent to SB-04 in Figure 35.

Figure 38. March 2015 short-line resistivity section across SB-04 perpendicular to levee and at same location as Figure 36.

Figure 39. March 2015 short-line resistivity section parallel to levee and across SB-04.

Figure 40. April 2015 long-line survey across SB-04 line perpendicular to levee (file 15033102).

Figure 41. April 2015 short-line survey semi-parallel to levee crossing SB-07................... 49

Figure 42. April 2015 long-line survey semi-parallel to levee and crossing SB-07. ........... 49

Figure 43. April 2015 long-line survey crossing SB-07, approximately

perpendicular to levee, southwest-northwest. 50

Figure 44. Location of sand boils, CPTs, and selected resistivity sections.........................53

Figure 45. Blanket thickness contour map in feet. Sand boil locations in yellow...............54

Figure 46. Elevation to the top of substratum sands (ft msl) .........................................55

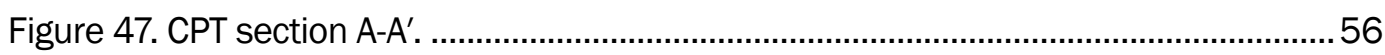

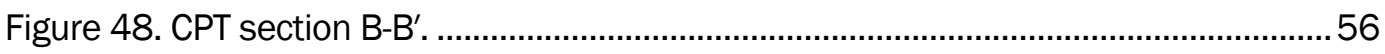

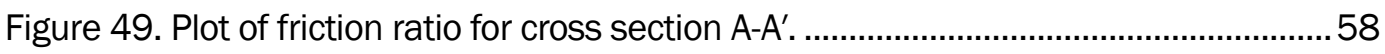

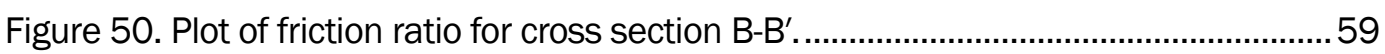

Figure 51. Comparison of CPT and resistivity data for cross section A-A'.........................60 
Figure 52. Comparison of CPT and resistivity data for cross section B-B' ....................... 61

Figure 53. Resistivity values as a function of earth materials (Palacky 1988)..................62

Figure 54. Primary variables for exit gradient calculations. ...................................................6 69

Figure 55. Relationship between exit gradient and severity of seepage and

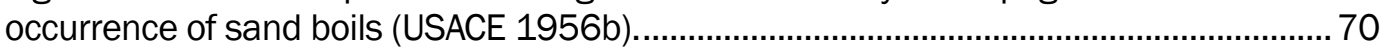

Figure 56. Design data for exit gradient values (USACE 1956b)....................................... 74

\section{Tables}

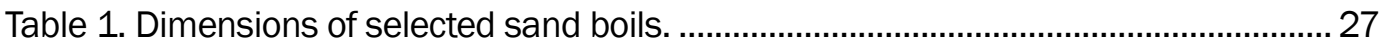

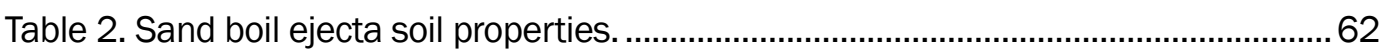

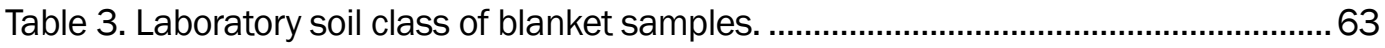




\section{Preface}

This study was conducted for the Flood and Coastal Storm Damage Reduction Program (FCSDRP) under the Project Resilient Infrastructure work unit for the "Empirical Study of Internal Erosion on Levees." Dr. Julie Rosati was the Technical Director of FCSDRP. The technical monitor for this work unit was Dr. Michael K. Sharp, Technical Director, Water Resources Infrastructure, Geotechnical and Structures Laboratory (GSL), U.S. Army Engineer Research and Development Center (ERDC).

The work was performed by the Geotechnical Engineering and Geosciences Branch (GEGB) and the Structural Engineering Branch (StEB). At the time of publication, Mr. Christopher G. Price was Chief, GEGB; and Ms. Anna M. Jordan was Acting Chief, StEB. Mr. James L. Davis was Chief, Geosciences and Structures Division (GSD). The Deputy Director of ERDC-GSL was Mr. Charles W. Ertle, and Mr. Bartley P. Durst was the Director.

COL Ivan P. Beckman was the Commander of ERDC, and Dr. David W. Pittman was the Director. 


\section{Unit Conversion Factors}

\begin{tabular}{|l|c|l|}
\hline Multiply & \multicolumn{1}{l|}{ By } & To Obtain \\
\hline feet & 0.3048 & meters \\
\hline inch & 0.0254 & meters \\
\hline miles (US statute) & $1,609.347$ & meters \\
\hline miles per hour & 0.44704 & meters per second \\
\hline mils & 0.0254 & millimeters \\
\hline ounces (mass) & 0.02834952 & kilograms \\
\hline pounds (mass) & 0.45359237 & kilograms \\
\hline pounds (mass) per cubic foot & 16.01846 & kilograms per cubic meter \\
\hline pounds (mass) per cubic inch & $2.757990 \mathrm{E}+04$ & kilograms per cubic meter \\
\hline pounds (mass) per square foot & 4.882428 & kilograms per square meter \\
\hline square foot & 0.09290304 & square meters \\
\hline square inch & $6.4516 \mathrm{E}-04$ & square meters \\
\hline square miles & $2.589998 \mathrm{E}+06$ & square meters \\
\hline square yards & 0.8361274 & square meters \\
\hline yards & 0.9144 & meters \\
\hline
\end{tabular}




\section{Introduction}

\subsection{Background}

Levee performance incidents occurred during flooding in 2011, 2013, and 2016 in the reach of the Middle Mississippi River between St. Louis and Cape Girardeau, MO. Levee performance incidents in this reach included severe underseepage and several large, high-energy sand boils at the land side levee toe. These recent floods varied from moderate to major events; however, water levels were well below the design flood the levees had been built to withstand. This report documents a case history study into the causes of underseepage at a levee site (Preston) in southern Illinois near the town of Ware, which is located in the Preston Drainage and Levee District (Figure 1).

Figure 1. Location of study site in southern Illinois.

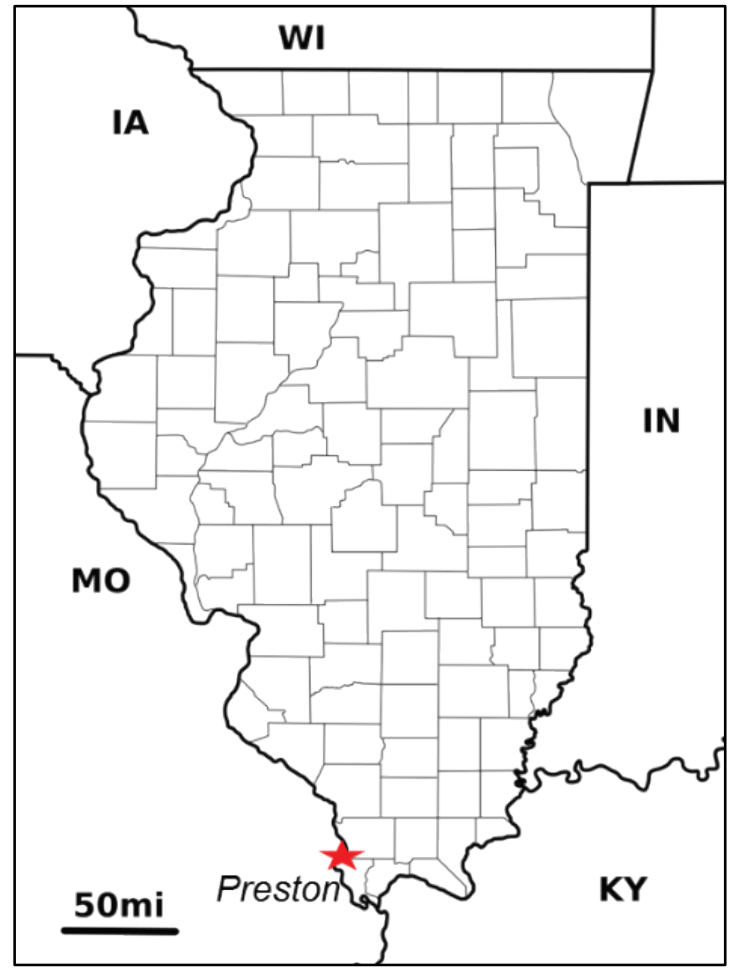

\subsection{Purpose and scope}

The purpose of this report is to examine several large sand boils near Ware, IL, to understand the factors involved in the underseepage that 
caused the boils at this location. Activities performed during the course of this study included a historical literature review, geologic mapping, field investigations, cone-penetrometer testing (CPT) to determine the underlying site stratigraphy, laboratory soils testing of sand boil ejecta from splitspoon samples, geophysical exploration, data analyses and reduction, and report preparation.

Site specific geotechnical data from the study area were used to identify parameters that contributed to underseepage conditions and poor levee performance. Factors, such as top stratum, or blanket thickness, Unified Soil Classification System (USCS) soil types, engineering soil properties, geologic depositional environments, stratigraphic context, and hydraulic gradients, can all influence levee underseepage. Results from this investigation will be used in other research efforts at the U.S. Army Engineer Research and Development Center (ERDC) to develop better predictive models and tools to evaluate levee performance and to improve current analytical solutions used by geotechnical engineers.

\subsection{Preston study site near Ware, IL}

The study area is located approximately 2.65 miles west of Ware, IL, on the east bank of the Mississippi River at river mile 071, based on the U.S. Army Corps of Engineers' Upper Mississippi River Navigation Maps, which has the confluence of the Mississippi and Ohio rivers near Cairo, IL (Figure 2), at mile zero. This site will be referred to as the Preston site in this study, after the Preston Levee and Drainage District where the sand boils occur. Several large-diameter, high-volume sand boils were identified after the 2013 Flood at the edge of a farm field in a designated Wetlands Reserve Program area at approximate levee station $765^{+00 .}$

Dr. Michael Navin, geotechnical engineer, U.S. Army Corps of Engineers (USACE), St. Louis Engineer District, Geotechnical Branch, led ERDC investigators to this field study site in 2014 as a case history site for underseepage research. Multiple sand boils had been discovered by a hunter in the fall of 2014 at the toe of the levee (Figure 3). The sand boils had not been previously disturbed, nor had they undergone flood fighting remediation. The sand boils dried after the 2013 Flood had receded. Cone heights of the sand boils were over $24 \mathrm{in} .(66 \mathrm{~cm})$ and some had diameters of over $5 \mathrm{ft}(3.6 \mathrm{~m})$. The affected area spanned a region as far as $150 \mathrm{ft}$ from the levee toe and involved a zone approximately $200 \mathrm{ft}$ in length parallel to the river. 
Figure 2. Location of the Preston site.

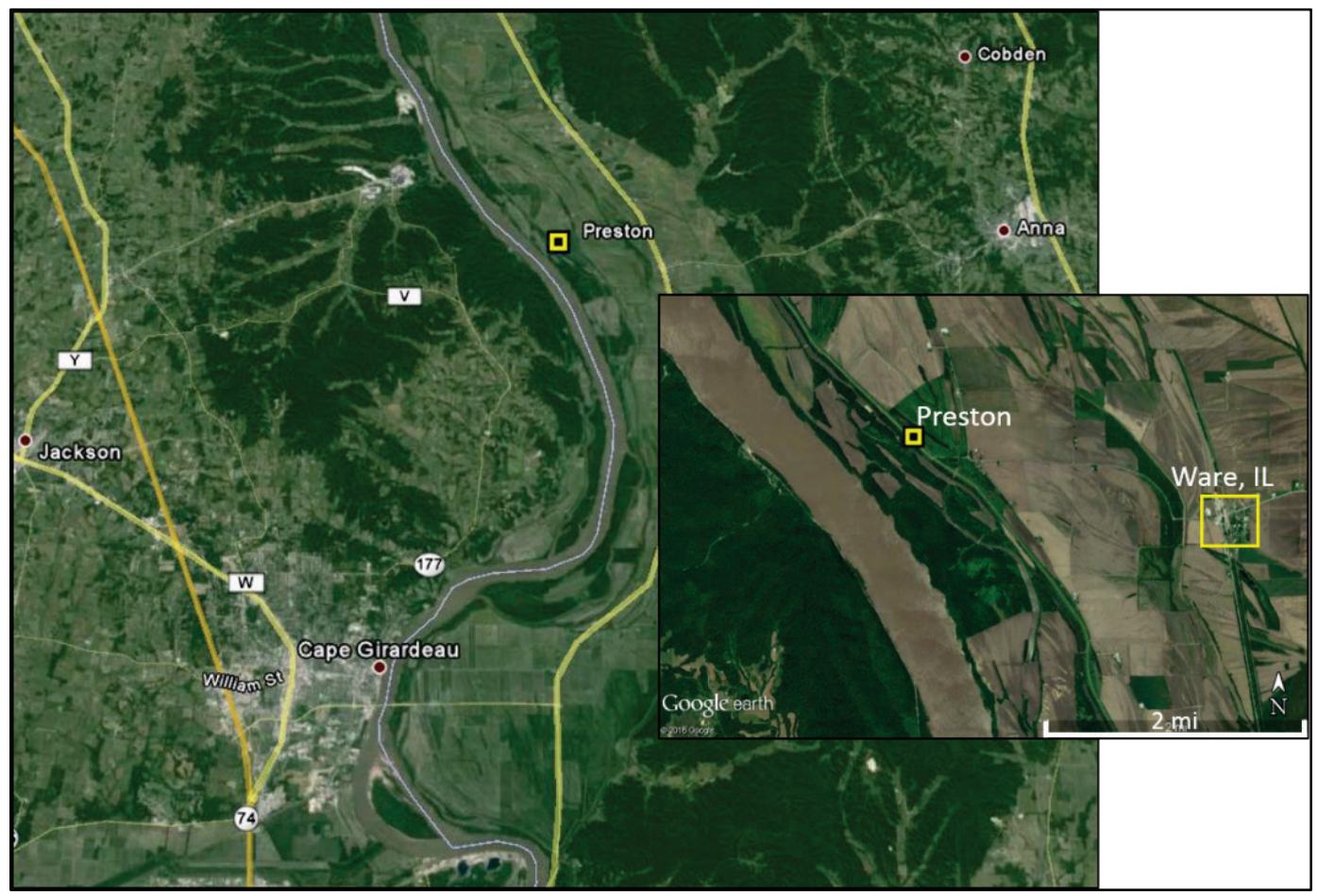

Figure 3. Ejecta cone observed by a large sand boil in 2014 at Preston study location.

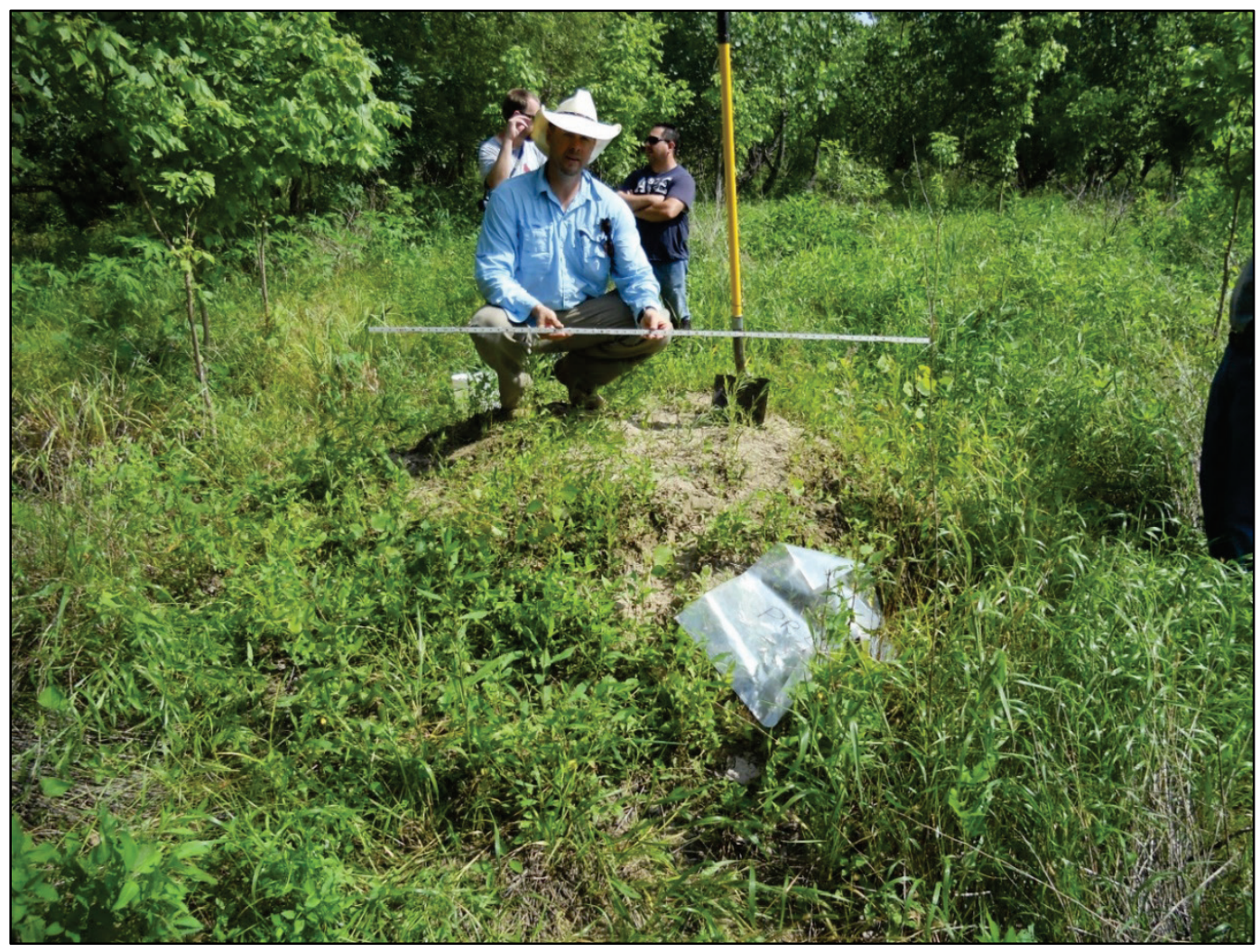


The Preston site in the Preston Levee and Drainage District is part of 14.9 miles $(24 \mathrm{~km})$ of levee in this district and is located in Union County, IL. This levee district is part of the Big Five Levee System, comprising 54.6 miles $(87.9 \mathrm{~km})$ of levee on the east bank of the Mississippi River (Figure 4). Federal-sponsored flood protection was authorized by the Flood Control Acts of 1936 and 1938. The Preston area is part of the larger Alton-to-Gale levee system in the Middle Mississippi River that was studied earlier by USACE (1956b) to effectively control levee underseepage.

\subsection{General mechanics of sand boils}

The development of sand boils and internal erosion (piping) is considered to be a major concern for the failure of levees. Turnbull and Mansur (1961) summarized the dynamics of sand boil development beneath levees undergoing flood-induced seepage:

If the hydrostatic pressure force in the pervious substratum (alluvial aquifer) landward of the levee becomes greater than the submerged weight of the overlying strata, the excess pressure may cause heaving of the upper soil layers and rupture at weak spots with a resulting concentration of seepage flow. Flow from these weakened locations may increase to form sand boils.

Problems with the levee foundation begin to occur once fine particles erode and are carried along as the seepage flow moves through the subsurface and eventually breaks the surface. An open channel results with a cone of sandy material on the landward side of the levee. This opening and ejecta cone are referred to as a sand boil. Many corrective measures including sand bagging around the boil, relief wells, seepage berms to add weight and to extend the seepage path, constructing cutoff walls through the foundation, and constructing sublevees to permit a tailwater to form behind the land side (USACE 1956a, 1956b), have been designed to relieve the hydrostatic pressure and to decrease and/or stop this process.

Some sand boil activity, including the type discovered at the Preston site, occurs during lower level floods. A common thought among many USACE levee engineers is that in chronic seepage areas, sand boil activity can form at lower levels of flooding because of the accumulated effects of internal erosion at these locations. 
Figure 4. Big Five Levee System protecting the east bank of the Mississippi River.

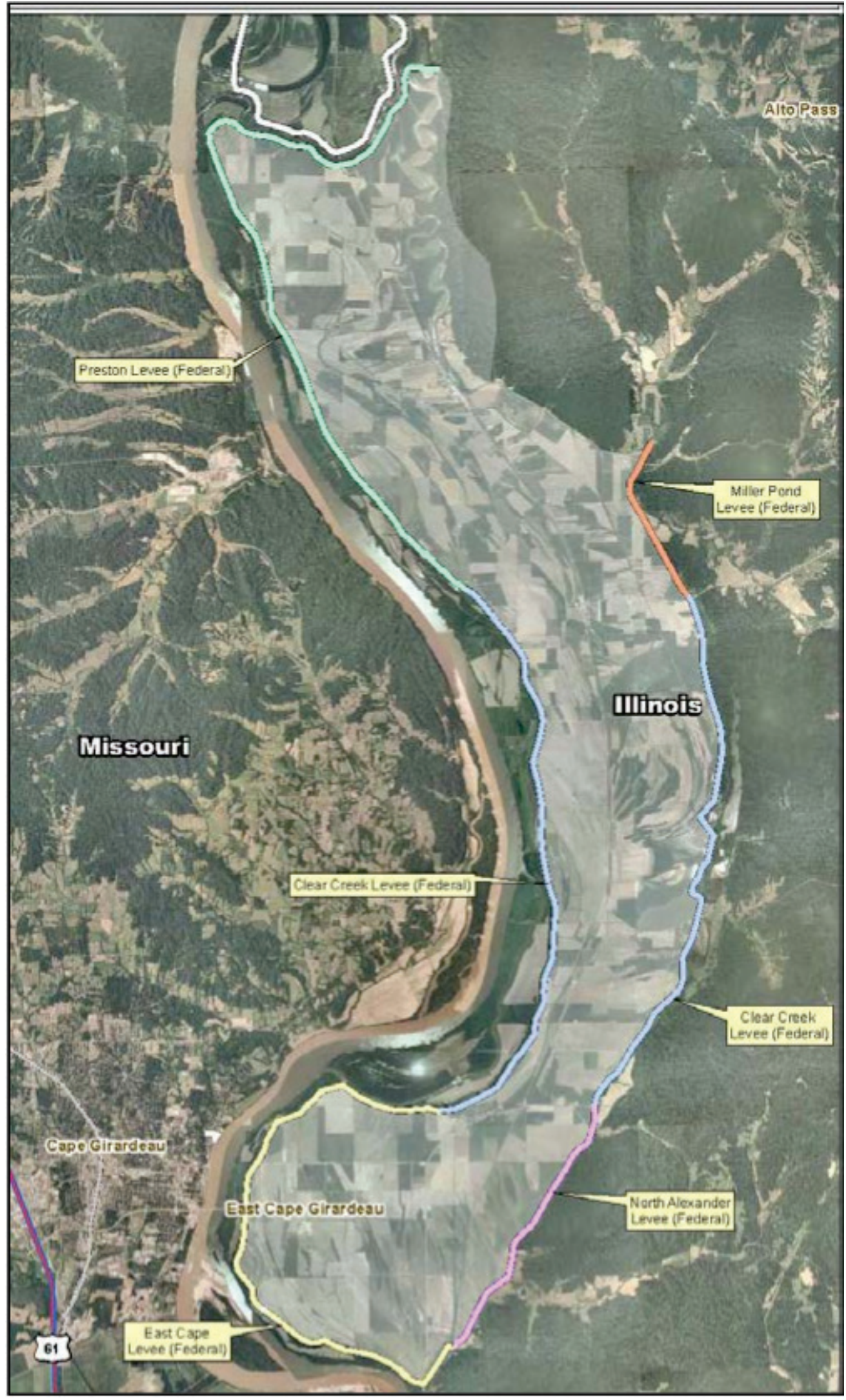




\subsection{Focus of case history studies}

Answers to questions about internal erosion that have historically not been addressed in earlier studies of underseepage (USACE 1956a, 1956b) are made possible from the current field study involving data collection and measured observations afforded by the Preston site. Important questions involving internal erosion to be examined during this investigation are as follows:

1. What are the engineering and geologic properties of the sand boil ejecta?

2. Where is the source of the ejecta in the stratigraphic column?

3. What are the contributing factors in terms of the geology and associated engineering properties?

4. Is it possible to image active sand boil areas with geophysical methods and identify characteristic signatures?

5. Can geophysical methods be used as a predictive tool for levee vulnerability?

\subsection{Units of measures used in this report}

Units of measure reported throughout this report include both English and metric values. Legacy USACE documents and district convention reports are in English measurements for project description, distance, elevation, river stage, and boring depth. Geophysical data by convention use metric values for measurement of ground resistivity and reporting of survey data. The assimilation of data used in this report incorporated both types of units of measure and their presentation. Thus, data reported herein use the corresponding system representative of their source. 


\section{Geologic Setting}

\subsection{Previous geologic studies}

Previous studies of the Preston area geology include 7-1/2 min quadrangle maps by the Illinois Geologic Survey (IGS) (Devera 1993) and ERDC 15-min scale surface geologic maps of Holocene-age (less than 10,000 yr) depositional environments in the Middle Mississippi Alluvial Valley (Woerner et al. 2003). IGS mapping by Devera (1993) identifies the surrounding bedrock chronostratigraphy but does not differentiate the Quaternary alluvium in the Ware Quadrangle. Mapping by Woerner et al. (2003) separates the Quaternary alluvium into distinct depositional environments and provides engineering context to these environments.

Additionally, USACE (1956b) conducted a systematic study of the subsurface stratigraphy and derived engineering properties for these soils for seepage control measures for the Alton-to-Gale levee system. Soil profiles in Volume II (1956b) were developed from the widely spaced engineering borings taken for the various levee reaches and separated into generalized depositional environments for characterization of the respective levee reaches. However, systematic valley-wide geologic mapping of depositional environments along the Mississippi River was not typically performed by USACE until the 1960s for the Lower Mississippi Valley (LMV) and the late 1980s for the Middle Mississippi Valley (MMV). Results of this system-wide geologic mapping effort are presented at the USACE LMV geologic mapping website (Imvmapping@erdc.usace.army.mil).

\subsection{Structural setting}

The Preston study area is located on the southern flank of the sinking Illinois Basin (Figure 5), with the rising Ozark Dome to the southeast (Seid 2013). During geologic time, the Mississippi River carved a fairly deep and narrow alluvial valley between 5 to 12 miles ( 8 to $19 \mathrm{~km}$ ) wide into the Illinois Basin sedimentary rocks. Underlying the Preston study area are Quaternary age (less than 2 million years) Mississippi River alluvial deposits and Silurian to Devonian age (416 to 443 million years ago) limestone bedrock (Devera 1993; Woerner et al. 2003). 
Figure 5. Location of Preston in relation to regional structural features (after Frankie et al. 2008).

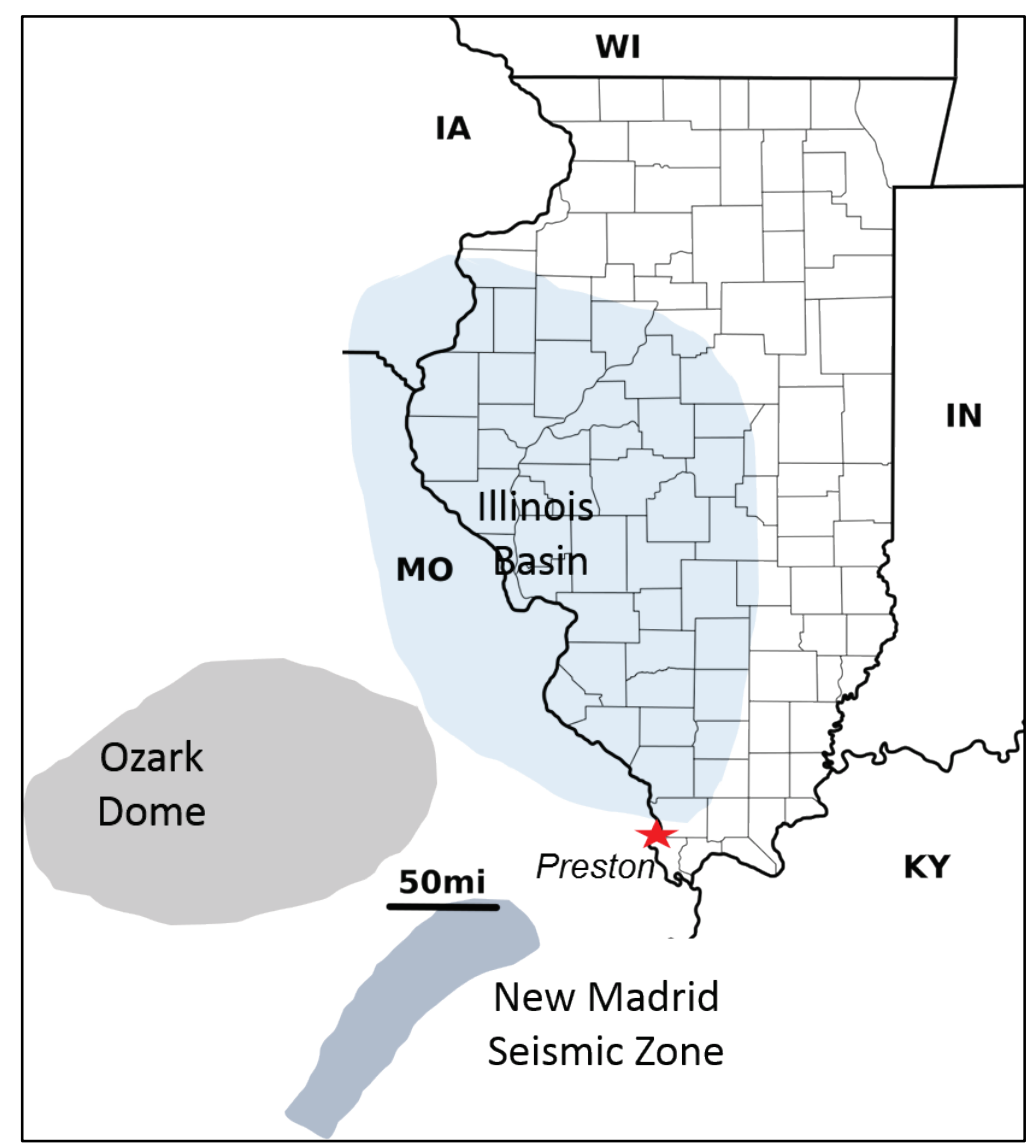

\subsection{Holocene depositional environments}

Mapping of depositional environments by Woerner et al. (2003) in the Preston reach indicates that the Mississippi River shifted courses across its narrow alluvial valley many times during the Holocene. The river through this reach has been a conduit for glacial meltwaters during the Pleistocene (10,000 to 2 million years). Primary depositional environments in the Preston levee reach include chutes and bars and point bar deposits (Figure 6).

The major difference between these two depositional environments involves the thickness and character of the top stratum sediments (Woerner et al. 2003). Chutes and bars tend to be much thinner and are typically more apt to be reworked by significant flood events and scouring from overbank flood flows. The development of historic flood control measures (dikes, revetments, levees) in the MMV has confined the river to a permanent channel and has prevented rapid channel evolution and 
migration that was characteristic of this system in the past. Descriptions of the different depositional environments are presented in more detail by Woerner et al. (2003). This report can be downloaded from the USACE website (Imvmapping.erdc.usace.army.mil).

Figure 6. Surface geology map of the Preston levee area showing depositional environments (Woerner et al. 2003).

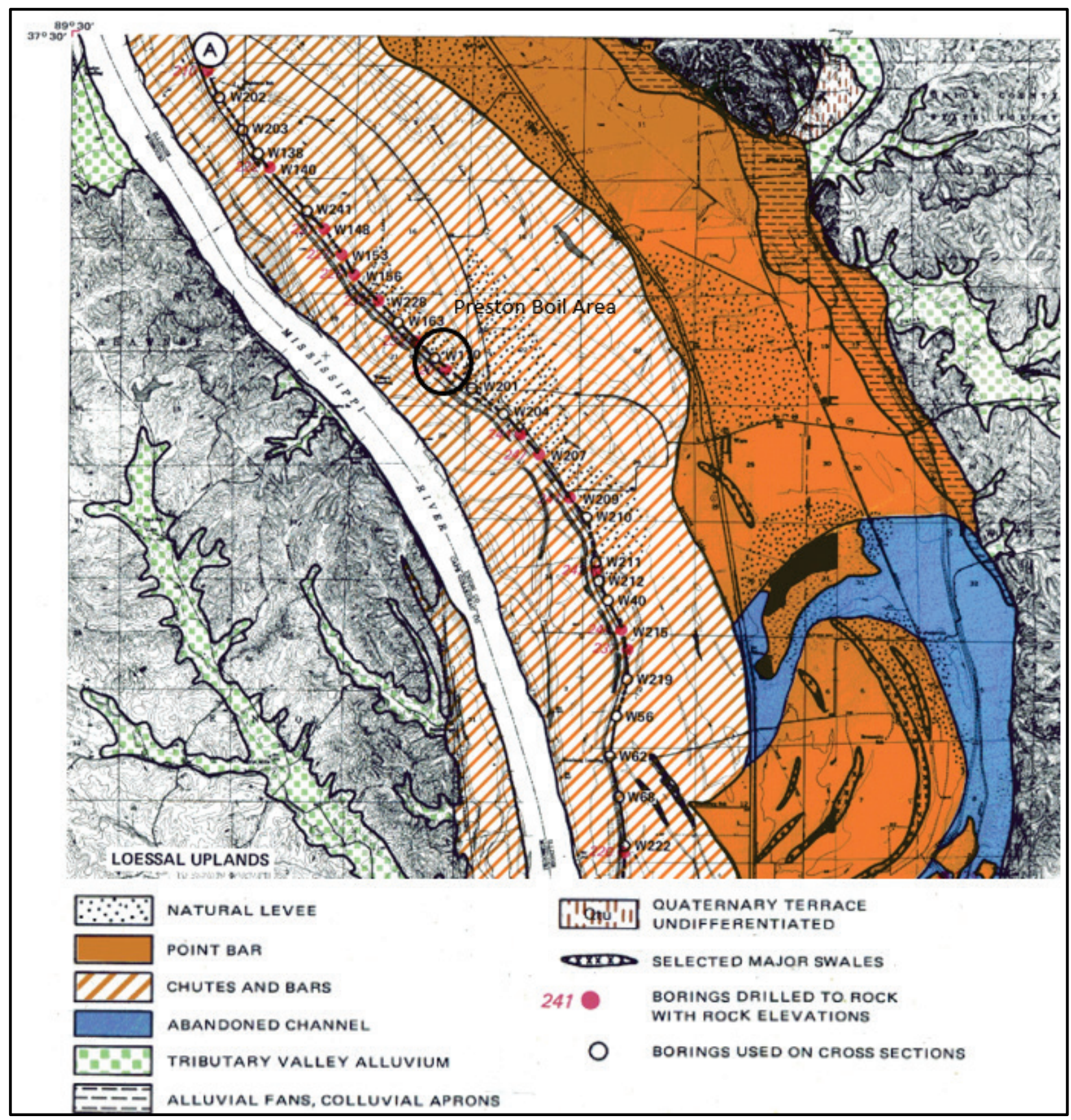


A generalized cross section of the Preston Levee reach is presented in Figure 7, showing the distribution of the alluvial deposits in the subsurface, based on the widely spaced borings in USACE (1956b). Alluvium in the Preston reach consists of both glacial and Mississippi River fluvial transported sediments covering the limestone bedrock, with combined thicknesses from 100 to $130 \mathrm{ft}$ ( 30.5 to $39.6 \mathrm{~m}$ ). The finegrained top stratum consists of clay, silt, and silty sand and ranges from less than 5 to $30 \mathrm{ft}$ ( 1.5 to $1.9 \mathrm{~m}$ ) in thickness. Pervious sand and gravel beneath the top stratum comprise the substratum or alluvial aquifer. The pervious aquifer is more than $100 \mathrm{ft}(30.5 \mathrm{~m})$ in thickness (USACE 1956b; Woerner et al. 2003).

Figure 7. Geologic cross section from the Preston Levee District reach.

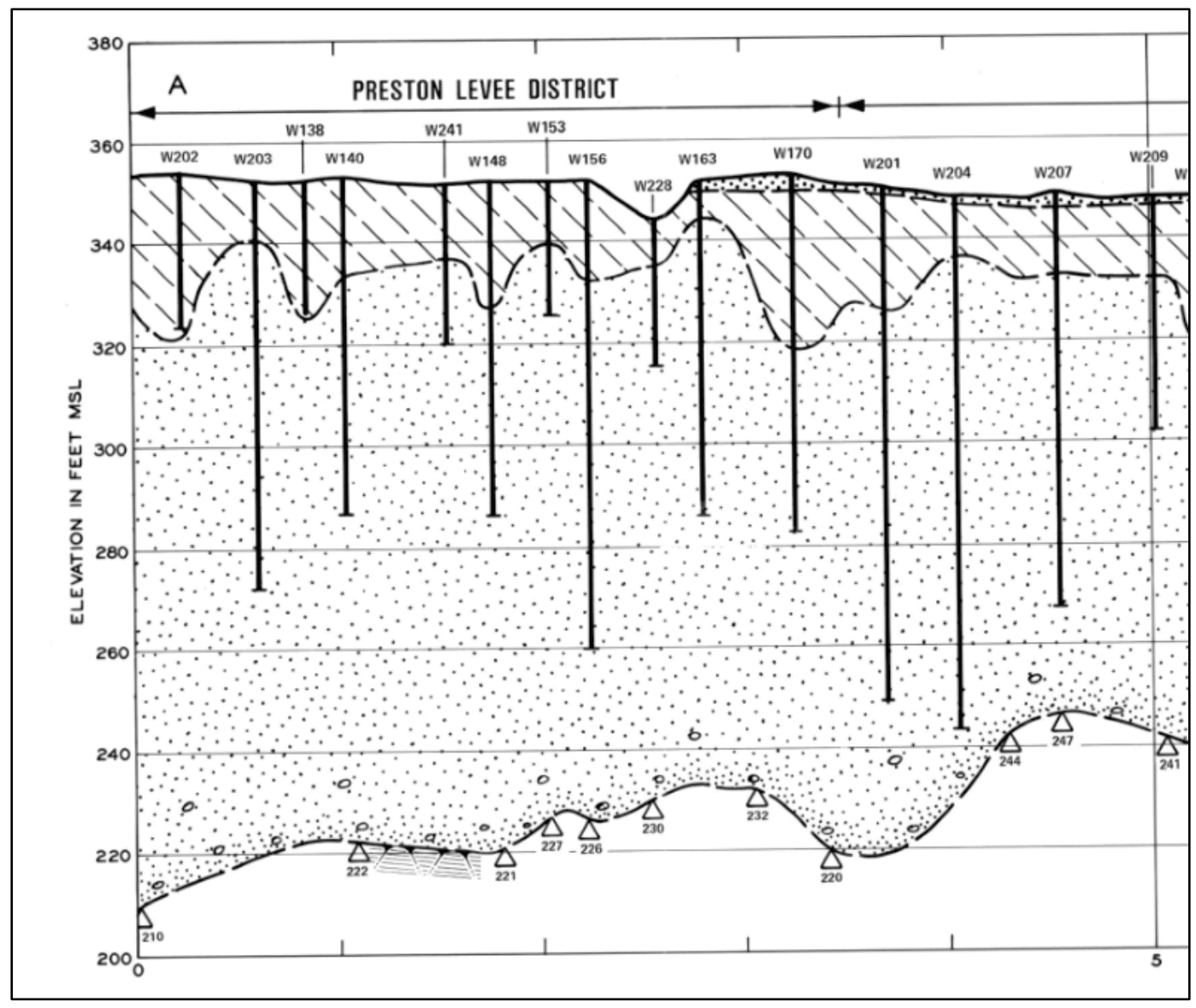

The focus of this study is a better understanding of recent sand boil activity in the vicinity of boring W170 (Figure 7). The top stratum at this location is much thinner than shown by Figure 7 based on topographic information. High resolution LiDAR (Light Detection And Ranging) data in Figure 8 show the character of the ridge (sandbars) and swale (chutes) 
Figure 8. Topographic profile across the Preston sand boil area derived from a 5-m Digital Elevation Model (DEM).
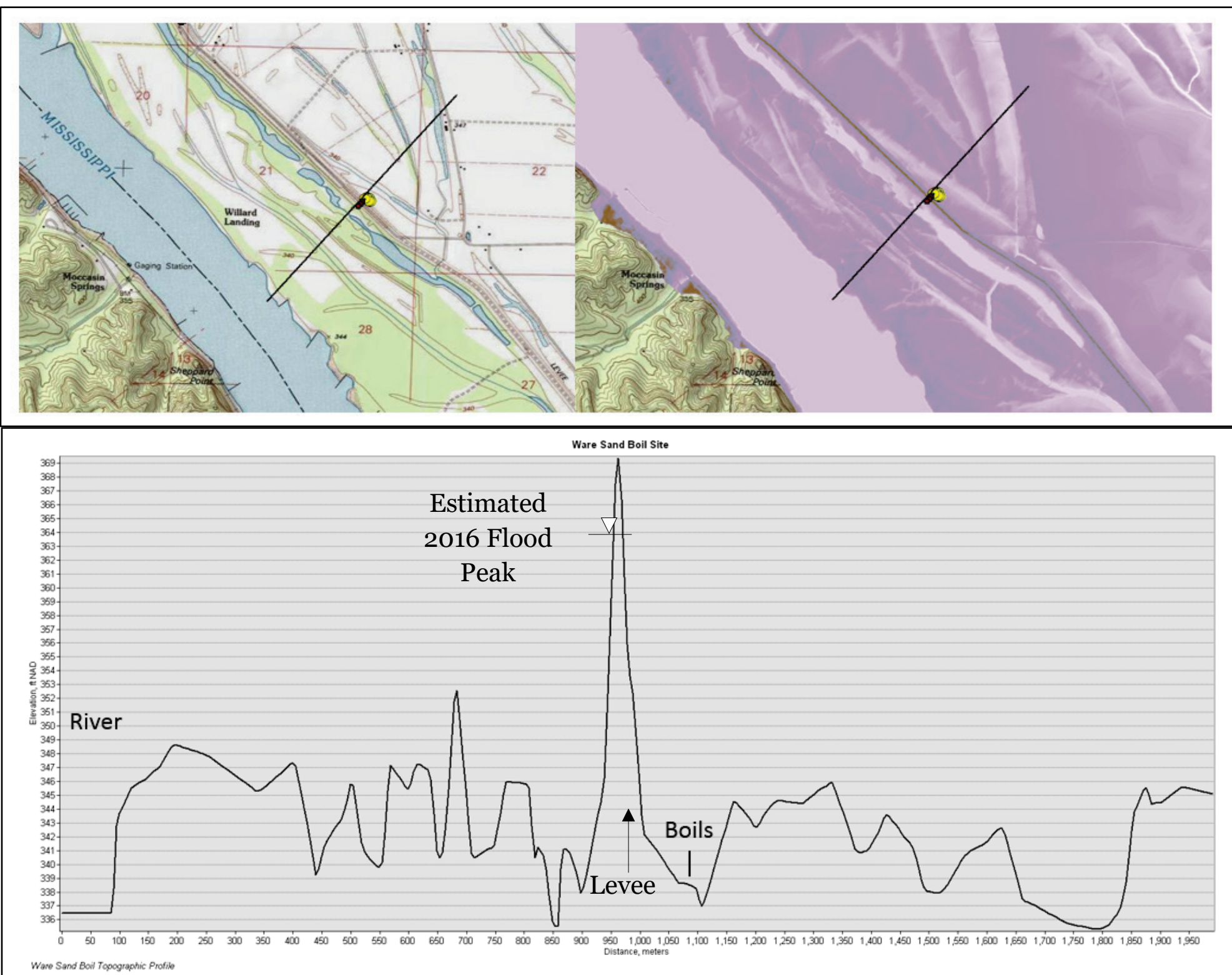
topography visible in the elevation profile. Low-lying areas in the topographic profile are locations of abandoned swales/chutes. The topographic profile in Figure 8 illustrates the variable nature of the local topography across this area. The area where large sand boil activity occurred is shown on the topographic profile.

Because of map scale, the surface geologic map in Figure 6 does not show the large swale that was prominent in this area, but it is clearly evident by the high resolution LiDAR data. The abrupt change in the depositional environments to a fine-grained chute/swale can have a significant influence on hydraulic pressure in the alluvial aquifer by creating a blocked exit condition locally (USACE 1956a, 1956b). The presence of blocked exits (horizontal and vertical flow direction) can concentrate seepage pressures and contribute to sand boil activity. This concept is shown by Figure 9. Contributing to the seepage and sand boil potential is the presence of deep borrow pits or open and partially sediment-filled channels at the riverside levee toe that extend into the alluvial aquifer.

Figure 9. Abrupt horizontal changes in particle size at boundaries of swales can concentrate underseepage in the aquifer and promote formation of sand boils. Open borrow pits or presence of deep channels on riverside of levee shorten the seepage path and increase the gradient (USACE 1956a, 1956b).

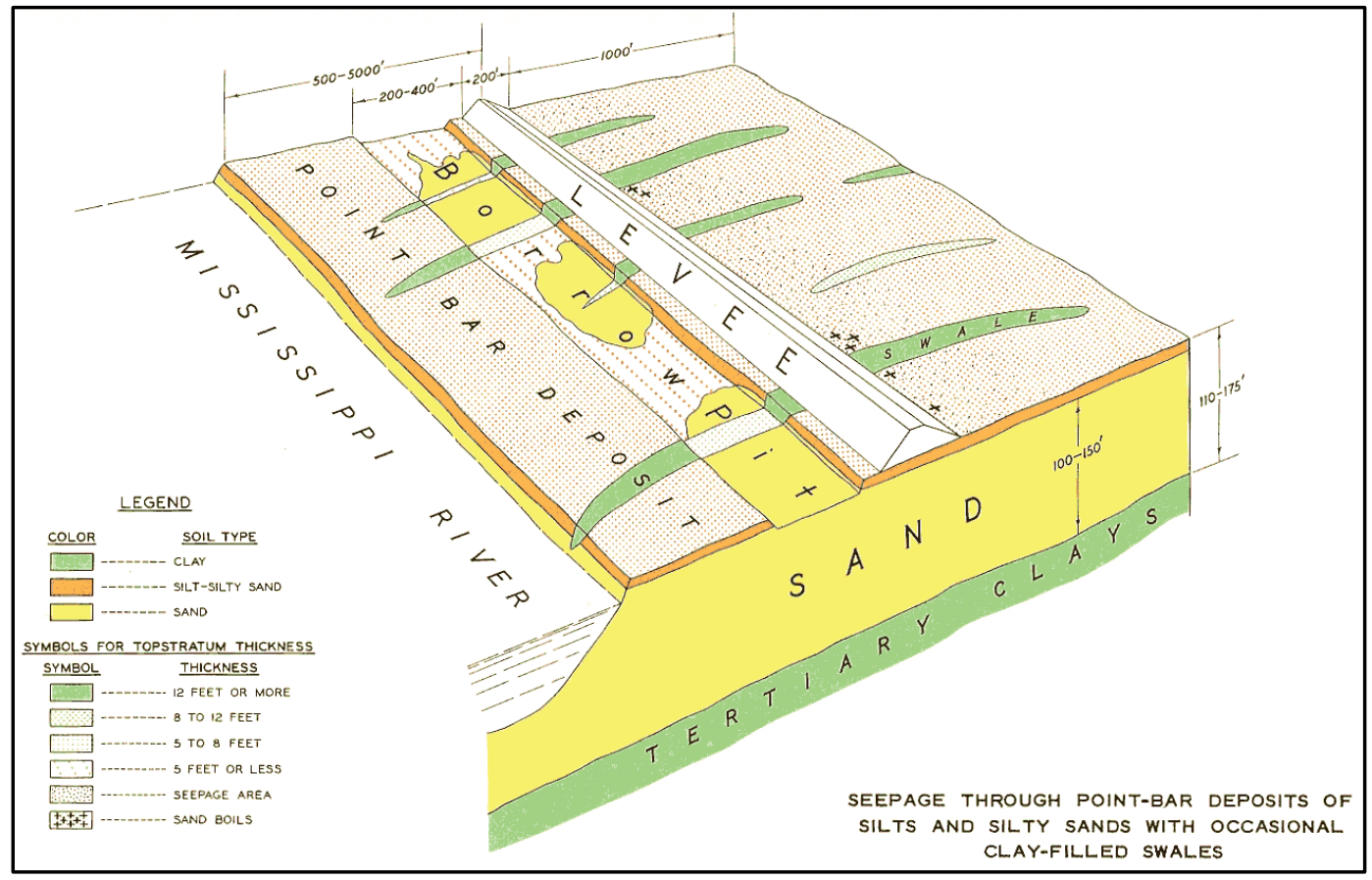


As shown by the LiDAR profile in Figure 8, both the riverside and land side toes of the levee sections contain fairly low elevations in comparison to the surrounding area. The deep channel at the riverside levee toe probably extends into the pervious aquifer, locally increasing the hydraulic gradient at this location, while the ground elevation at the land side levee toe is also fairly low in comparison to adjacent surface areas. Thus, during flood stage, the hydraulic head at this location would be fairly high because of the riverside entry point and the low-lying ground surface in the land side area. Local gradients vary due to topography, namely elevation differences between the flood and land side, blanket thickness, flood stage, and levee orientation with respect to the ridge and swale topography of the floodplain. 


\section{Field Studies}

\subsection{Approach}

The field investigation phases, in order of occurrence, involved a site reconnaissance during both dry and flood stage conditions. Next, geophysical surveys of the site were performed with a focus on characterizing the underlying stratigraphy and imaging selected large sand boils. CPT characterization of the site on selected sand boils was performed to determine specific soil types comprising geophysical signatures and the underlying stratigraphy. Finally, detailed mapping and trenching of a large sand boil were performed to examine the pathways through the blanket. Additionally, as part of the CPT site characterization and trenching, laboratory soil testing of ejecta on selected soil samples was performed to derive grain-size properties. Field activities are presented in this section in their general order of occurrence to this study.

\subsection{Site reconnaissance}

An initial inspection of the Preston site was conducted in June 2014. Eight sand boils were located and flagged for later study (Figure 10). The large sand boil previously shown in Figure 3 corresponds to SB 7 in Figure 10. These boils were discovered by local hunters in 2013 and were reported to the local levee district personnel.

Ejecta samples were collected from five of the sand boil cones during the initial site inspection. Grain-size classification of the ejecta samples was conducted in the laboratory. These data are presented in Appendix A.

\subsection{Geophysical surveys}

\subsubsection{Introduction}

Geophysical surveys were performed to image the subsurface to determine basic stratigraphic properties of the site, to identify any anomalous geophysical signatures that exist, and to characterize the stratigraphy and soils comprising selected large sand boils. Non-invasive methods were chosen prior to any site disturbance. Thus, CPTs were not initially performed for signature verification because of site disturbance issues involving fairly wet surface soils. 
Figure 10. Locations of eight flagged sand boils at Preston.

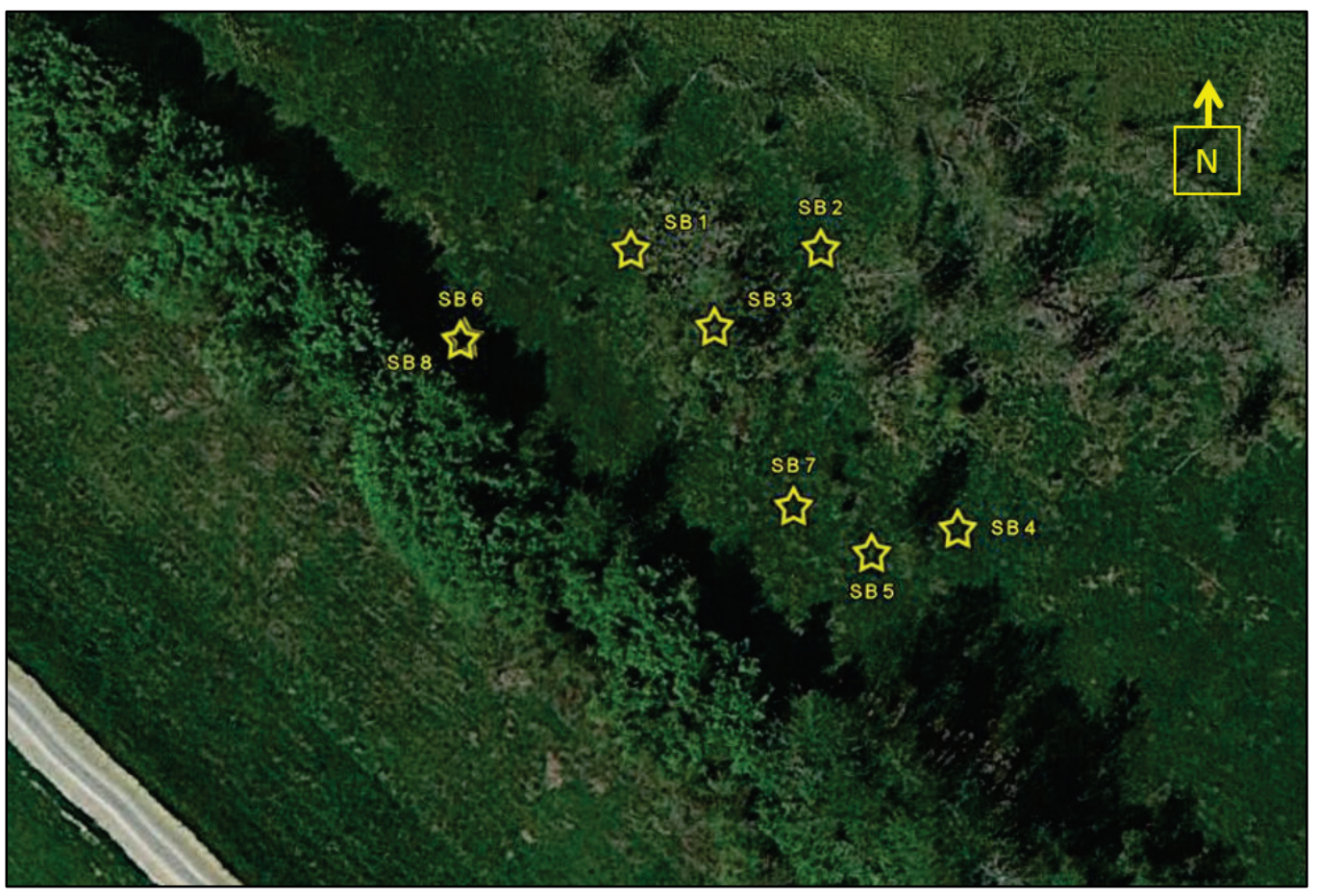

\subsubsection{Method and survey chronology}

Electrical Resistivity Tomography (ERT) was used to image the subsurface in the immediate vicinity of the sand boils at the Preston site. Resistivity surveys measure the resistance to electrical current flow through the earth, which is a function of the electrical properties of the disparate soils and stratigraphy located in the subsurface. The objective of these surveys was to provide an initial two-dimensional (2-D) view of the stratigraphy and to investigate which zones are impacted in the subsurface by sand movement prior to performing invasive CPT collection methods. Surveys were performed on two separate occasions: 23-25 September 2014 and 31 March to 01 April 2015. Sand boils number 4 (SB-04) and 7 (SB-07), shown in Figure 11, were selected for detailed evaluation and inspection using ERT methods.

\subsubsection{Equipment and type of surveys}

Twelve ERT surveys were conducted by using a SuperSting R8 electrical resistivity imaging system, manufactured by Advanced Geosciences, Inc. (Figures 11 through 15). All 12 surveys were conducted by using a dipoledipole array using 84 electrodes, spaced at one of two electrode spacings: $0.3 \mathrm{~m}(1.0 \mathrm{ft})$ or $0.8 \mathrm{~m}(2.6 \mathrm{ft})$. Geophysical data by convention are 
presented using the metric system. Surveys that used an electrode spacing of $0.3 \mathrm{~m}(1.0 \mathrm{ft})$ were $24.9 \mathrm{~m}(81.7 \mathrm{ft})$ in length at the ground surface and are referred to in this report as short surveys, while surveys that used an electrode spacing of $0.8 \mathrm{~m}(2.6 \mathrm{ft})$ were $66.4 \mathrm{~m}(217.8 \mathrm{ft})$ long at the ground surface and are referred to in this report as long surveys.

Figure 11. Select sand boil locations at the Preston site. Stars denote the location of sand boils.

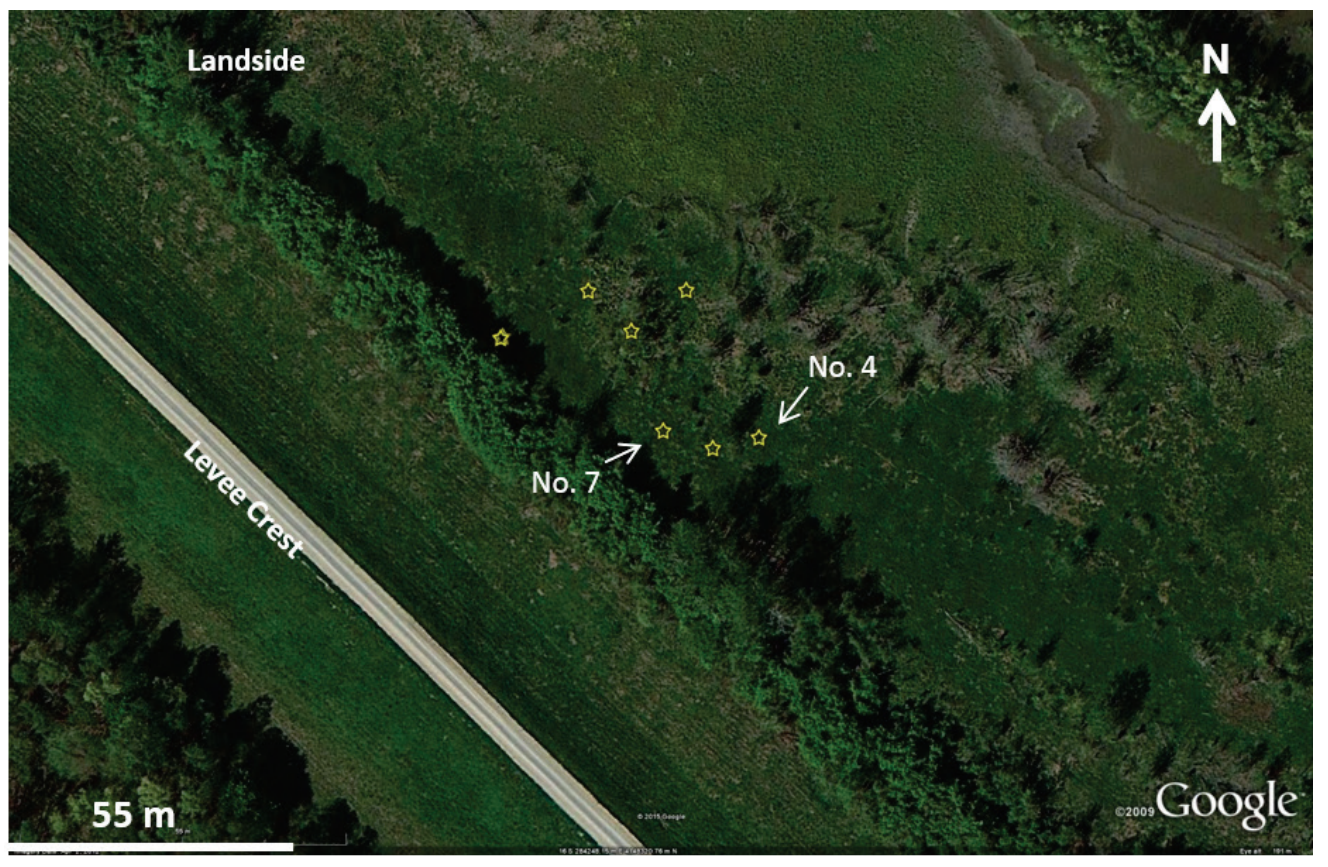


Figure 12. View looking northeast. AGI SuperSting system in operation over SB-07 at Preston site.

Electrode spacing of $0.8 \mathrm{~m}$.

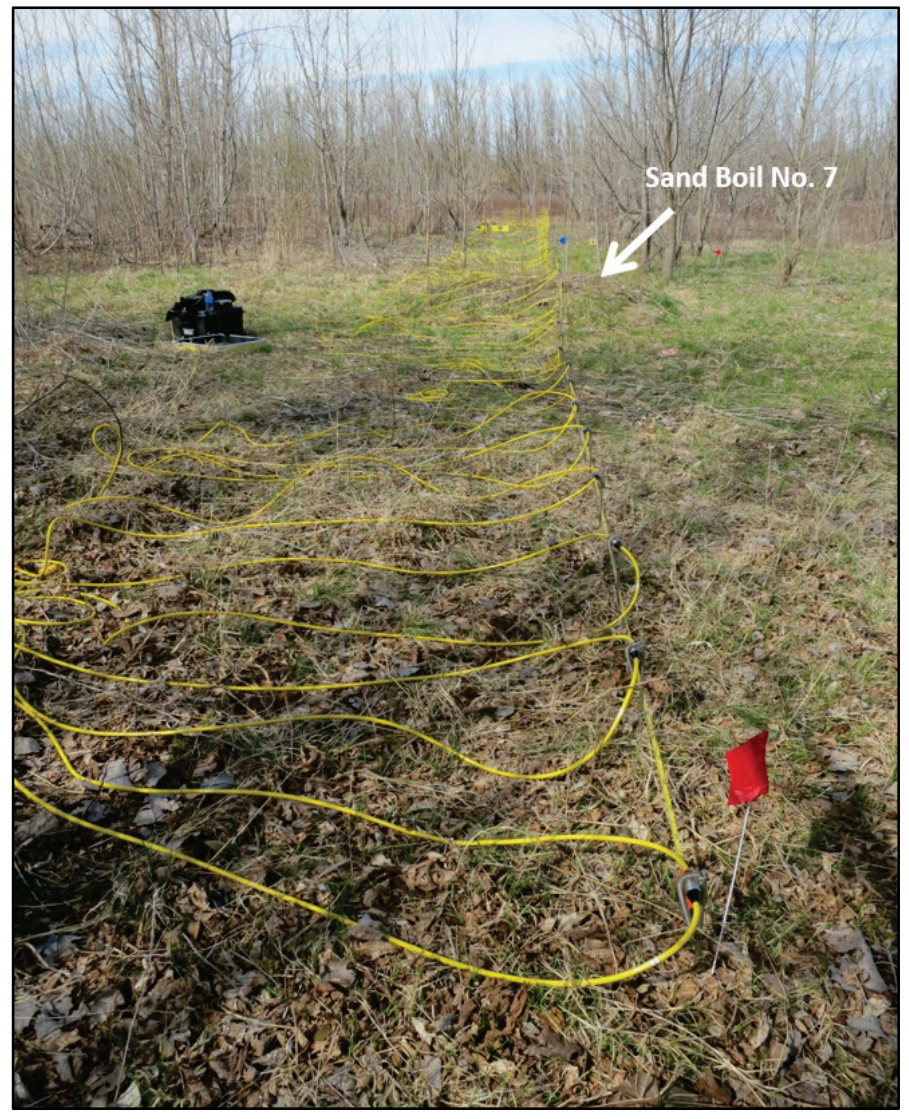

Figure 13. View of AGI SuperSting power source, command box, and switch box.

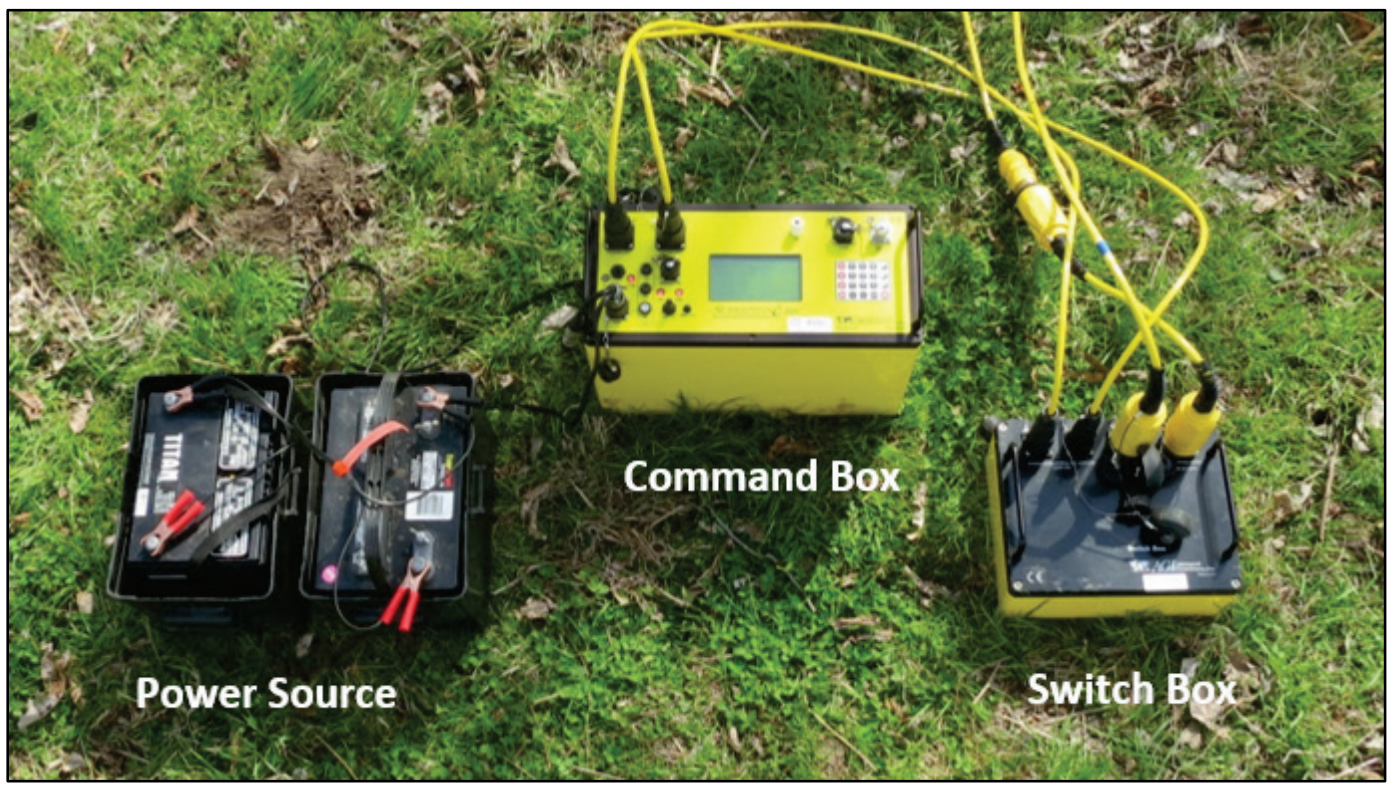


Figure 14. View of ERT survey set up crossing SB-04.

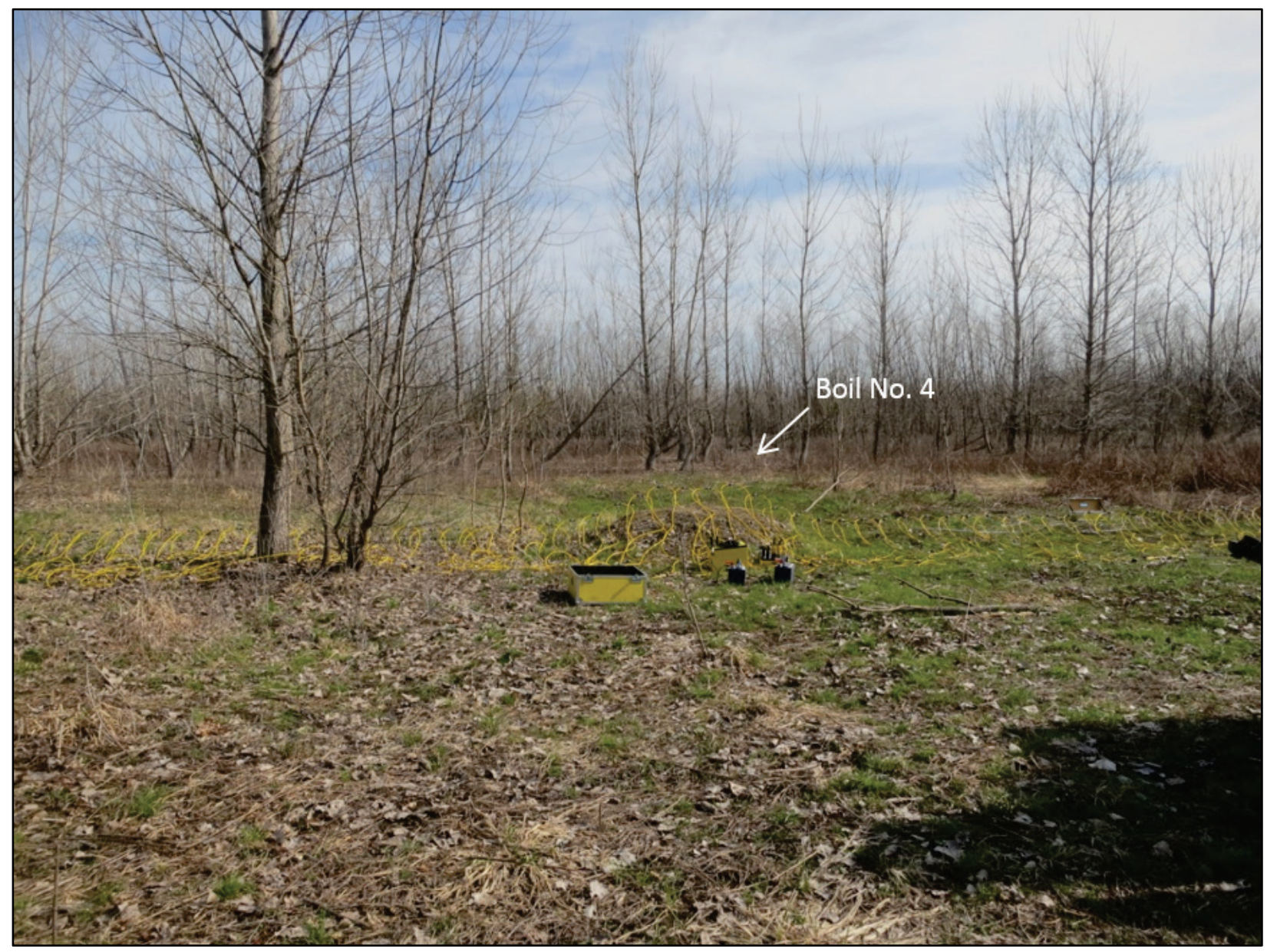


Figure 15. Location of different ERT surveys performed at the Preston site.

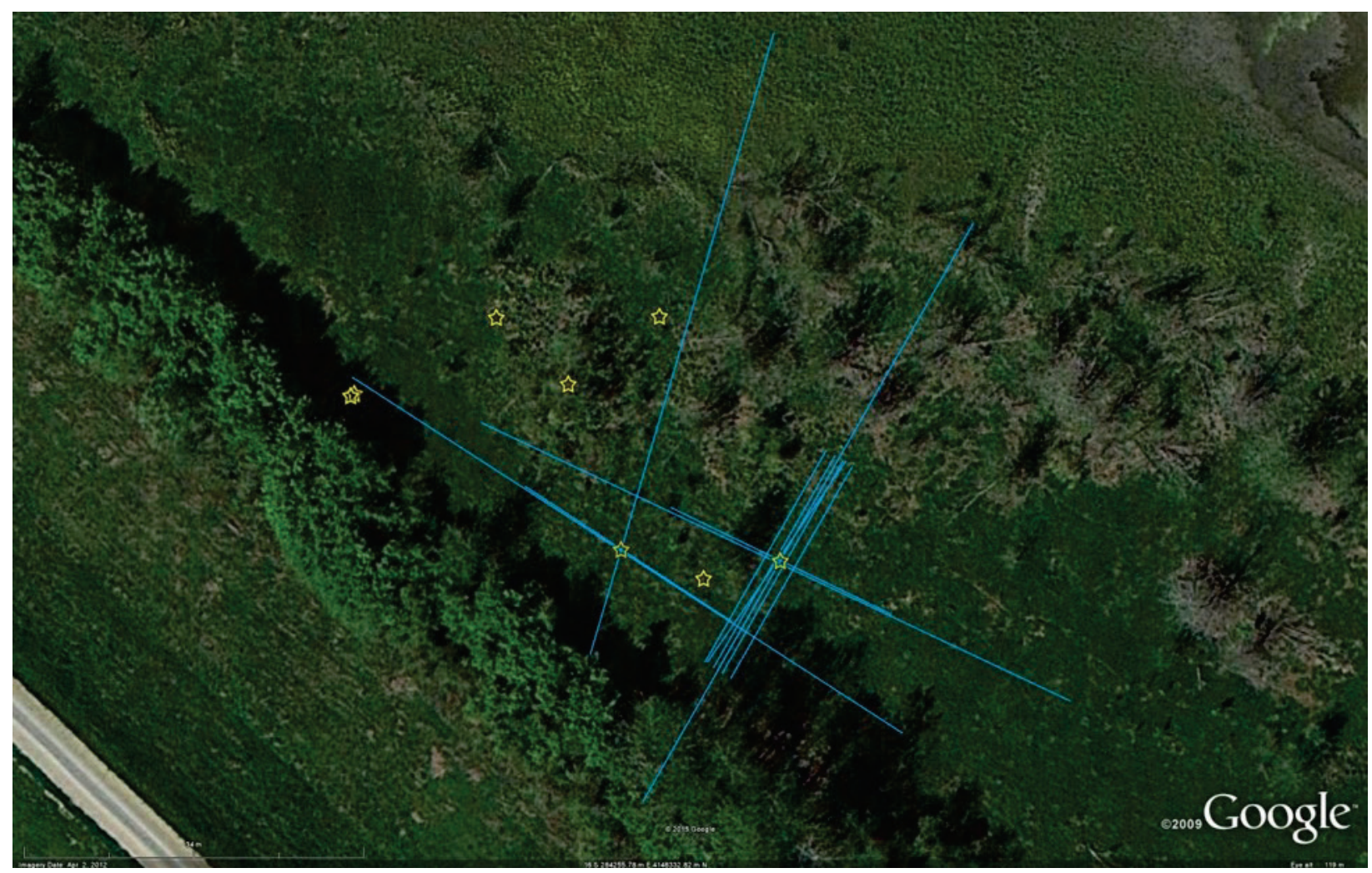

The choice of two different electrode spacings permitted high resolution imaging of the near surface with the short survey versus deeper penetration of the blanket and upper aquifer by the longer surveys. Additionally, the ERT surveys were focused on two of the sand boils. SB-04 and SB-O7 (Figure 11) were selected for the ERT surveys because of their accessibility and their size. Some of the other boils at the site were smaller and, in turn, deemed of less interest, and some were located among trees and woody vegetation, hindering the ability to set up linear ERT surveys across the boil. ERT surveys were performed both parallel and perpendicular to levee orientation while bisecting the selected sand boils.

\subsubsection{Investigation of Sand Boil No. 4}

In September 2014, six ERT surveys were conducted in the vicinity of SB-04 (five short surveys and one long survey). Five of these surveys formed a fine grid centered on SB-04 (Figure 16). Each of these surveys was $24.9 \mathrm{~m}(81.7 \mathrm{ft})$ long and used a uniform electrode spacing of $0.3 \mathrm{~m}$ $(1 \mathrm{ft})$. 
Figure 16. Close-up view of fine survey grid conducted over SB-04.

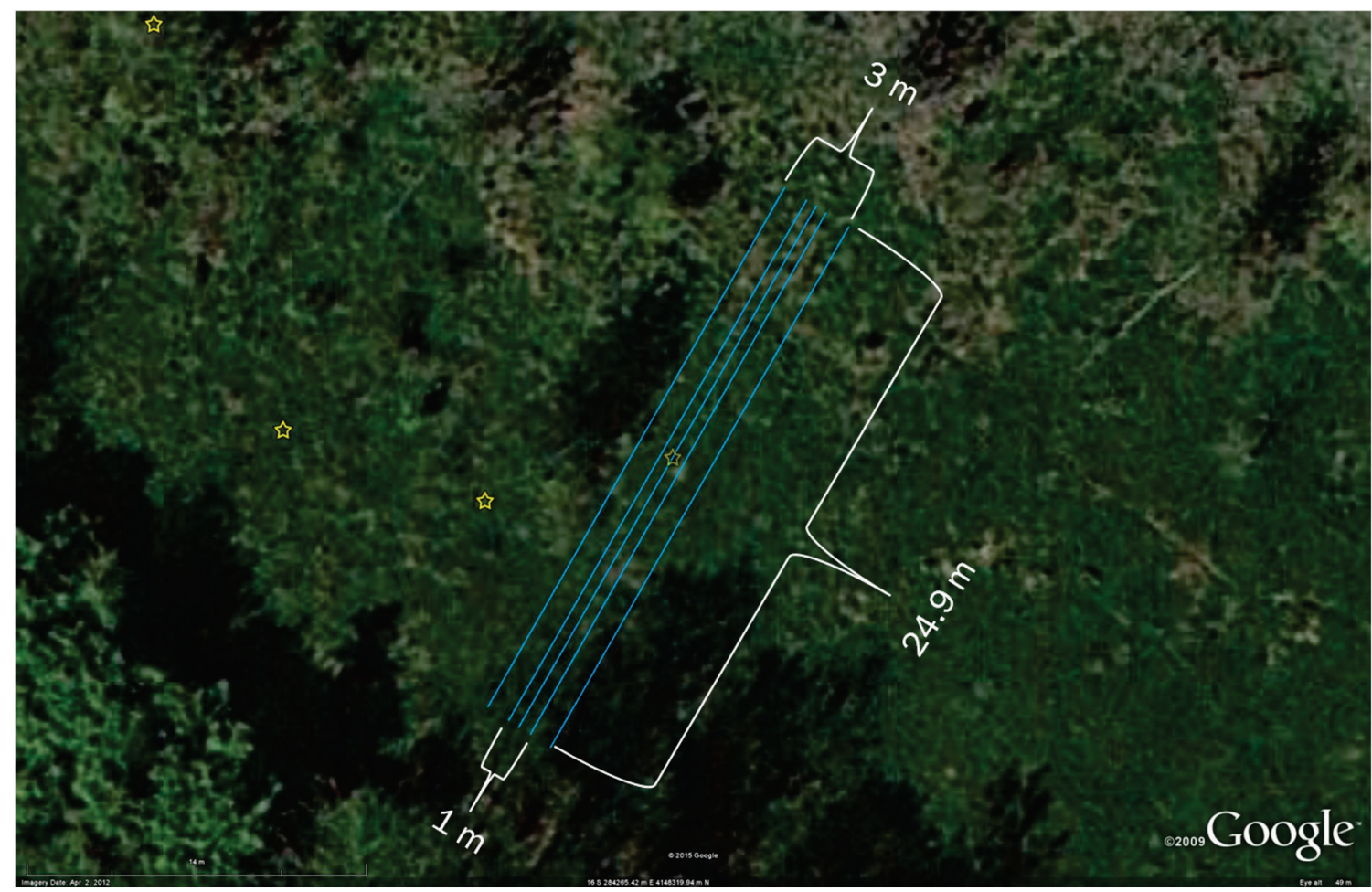

The inner three surveys had an interline spacing of $0.5 \mathrm{~m}(1.6 \mathrm{ft})$, while the two outer surveys were offset by $1 \mathrm{~m}$ (3.2 ft) to the northwest and southeast (Figure 16). The sixth and final survey, conducted September 2014, used a larger electrode spacing of $0.8 \mathrm{~m}$ (2.6 ft), providing longer survey length and a greater depth of investigation than the previous five surveys that composed the fine grid (Figure 17). This sixth survey was conducted along the same survey path as the central survey line of the fine grid; however, due to the greater electrode spacing, the sixth survey extended farther in distance to the southwest and northeast than the fine grid (Figure 17).

On 31 March 2015, three additional ERT surveys were conducted crossing SB-04. The first survey was a short survey centered on SB-04 and oriented perpendicular to the previously collected fine ERT grid (Figure 18). The second survey was a long survey centered on this sand boil and also oriented perpendicular to the previously collected fine ERT survey (Figure 19). The third and final survey collected on 31 March was centered on SB-04 and located entirely within the confines of the area previously surveyed by the fine ERT grid (Figure 20). 
Figure 17. View of $66.4-\mathrm{m}$ - (217.8-ft-) long survey perpendicular to and centered on SB-04.

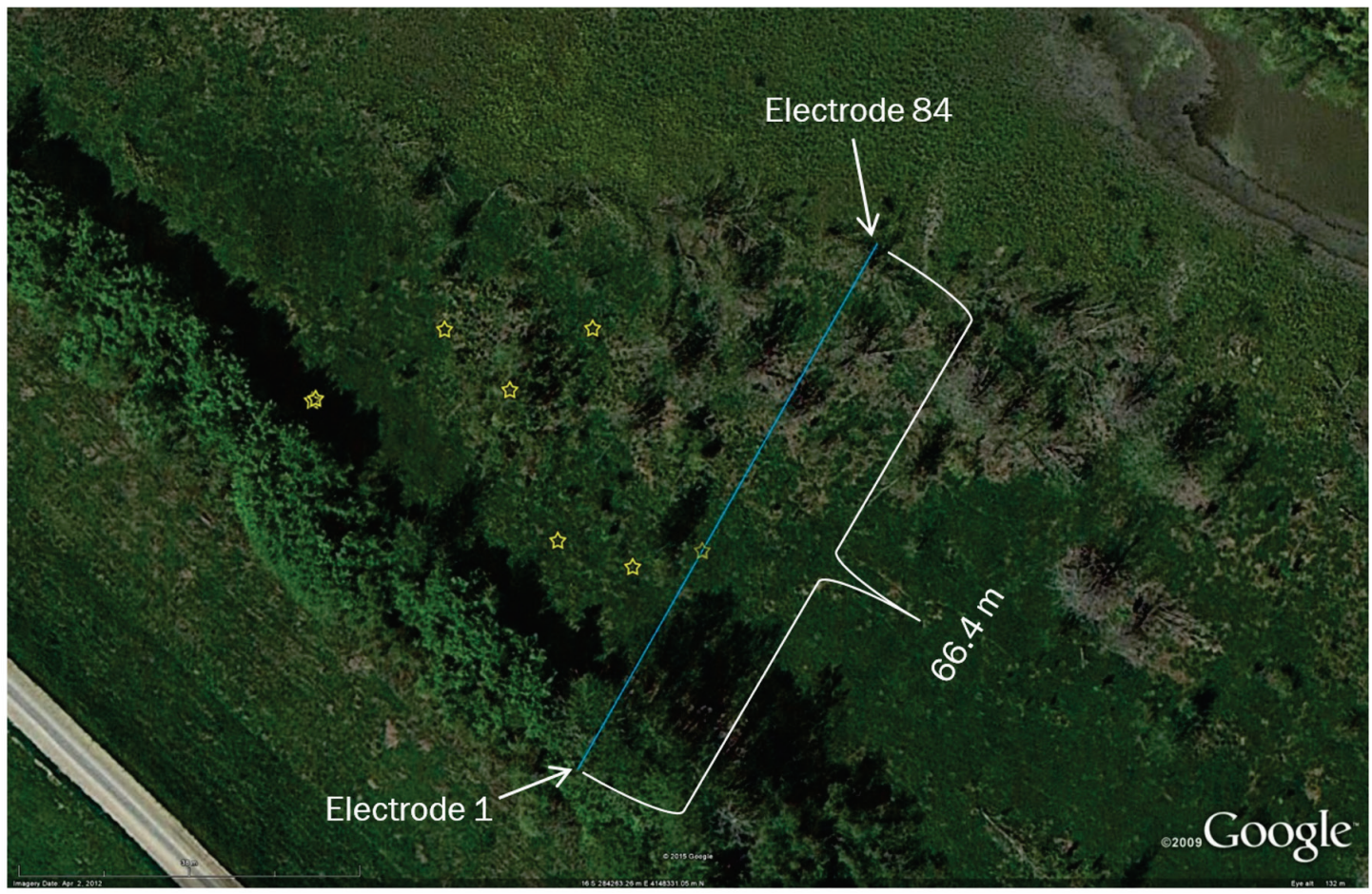

Figure 18. View of parallel survey with electrode spacing of $0.3 \mathrm{~m} \mathrm{(1 \textrm {ft } )}$ and survey length of $29.4 \mathrm{~m}(81.7 \mathrm{ft})$ on SB-04.

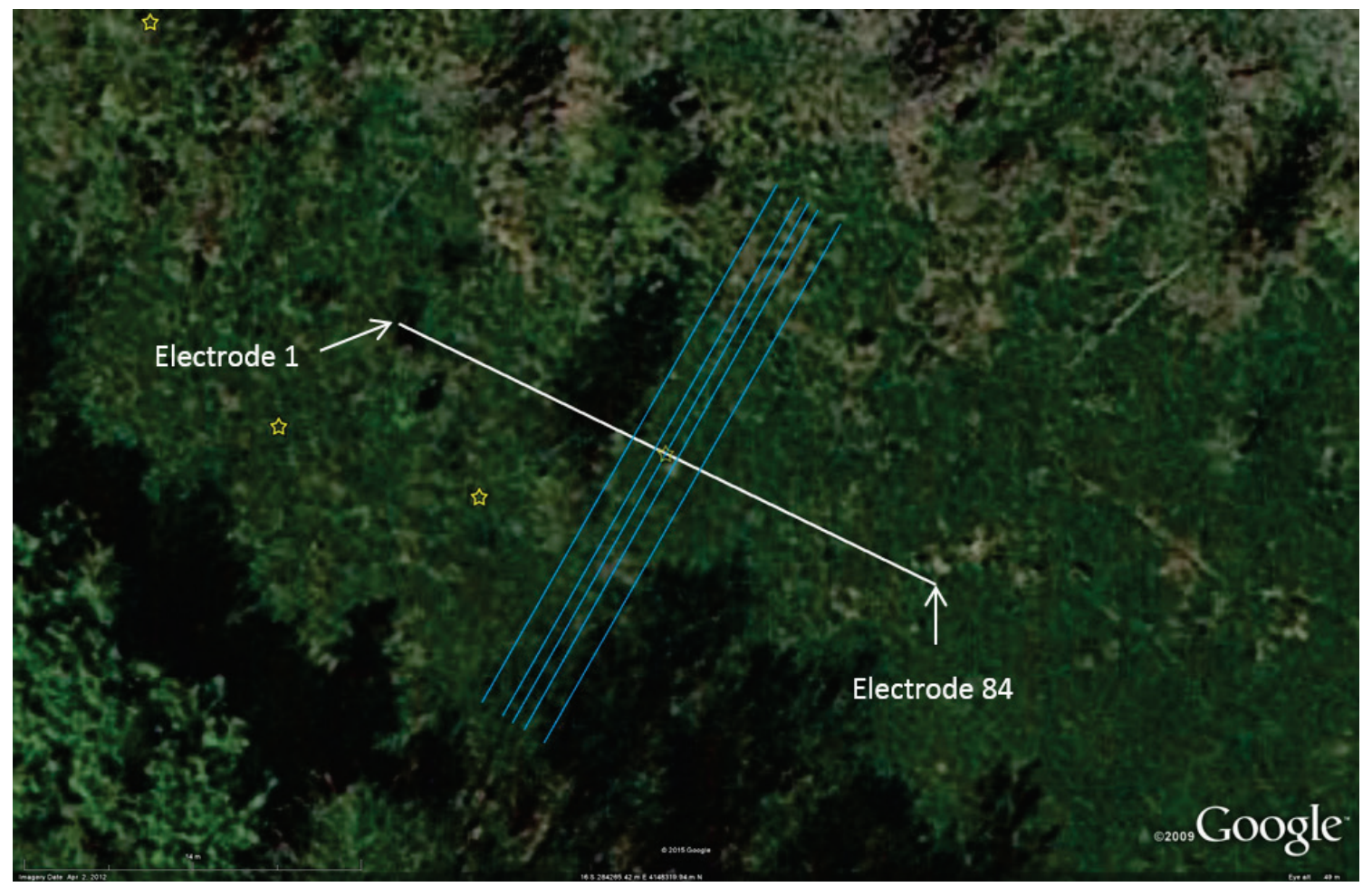


Figure 19. View of survey with electrode spacing of $0.8 \mathrm{~m}(2.6 \mathrm{ft})$ and survey length of $66.4 \mathrm{~m}(217.8 \mathrm{ft})$ for SB-04.

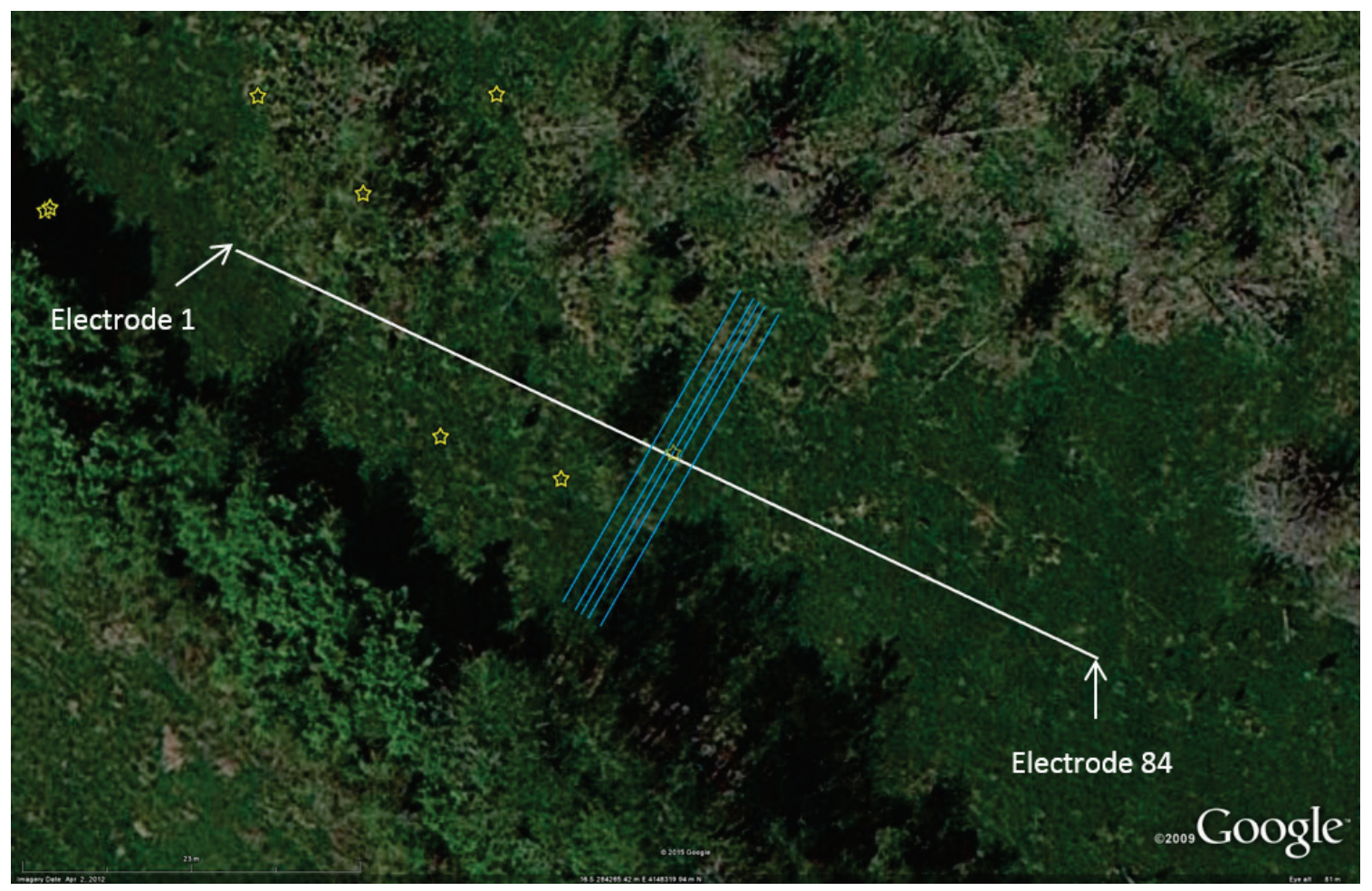

Figure 20. Additional oblique survey (white line) conducted within the grid fine (0.3-m [1-ft] electrode spacing) area and across the sand boil.

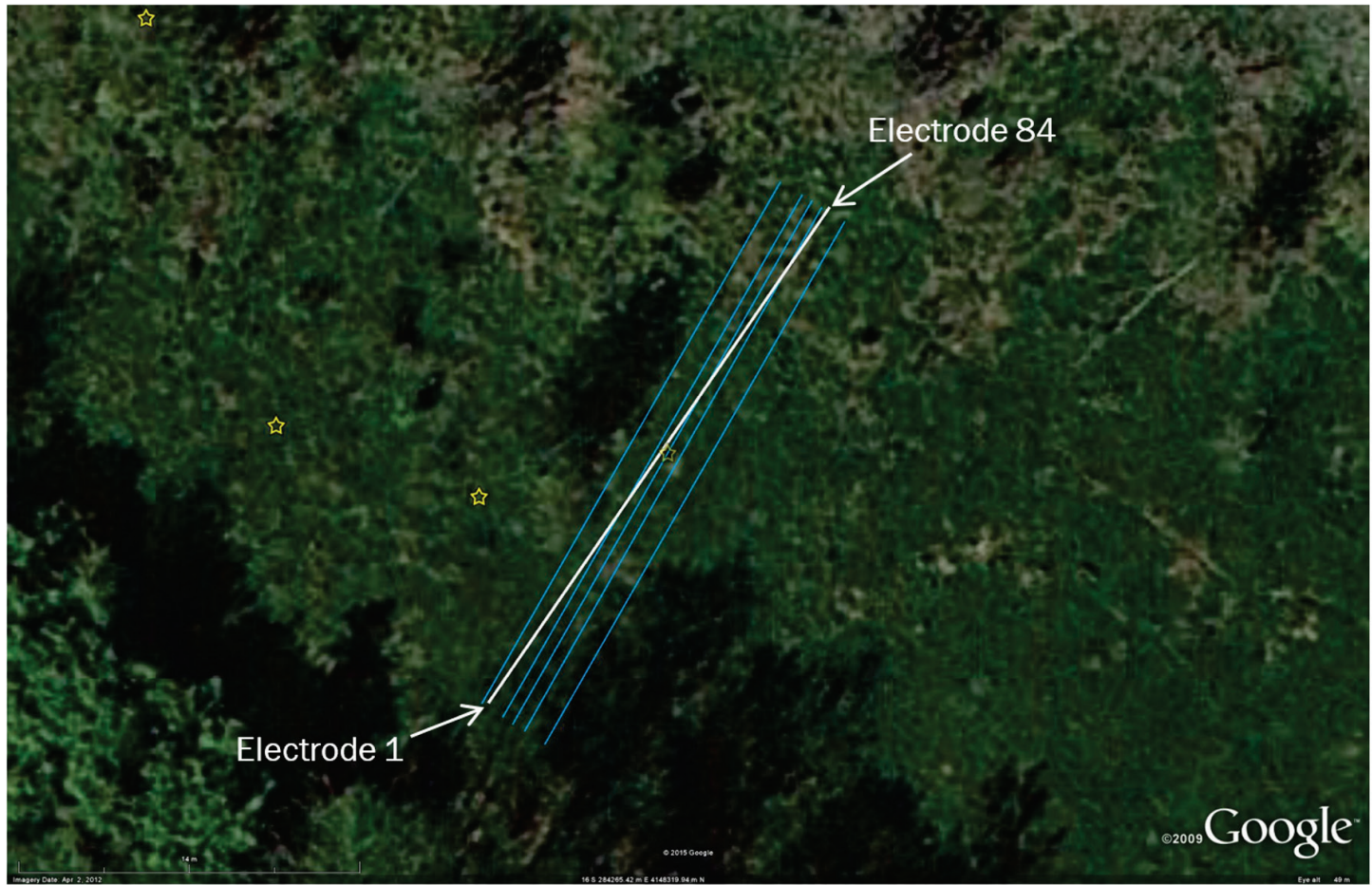




\subsubsection{Investigation of Sand Boil No. 7}

Three ERT surveys that crossed SB-07 were conducted on April 2. The first survey was a short survey centered on the sand boil and oriented semiparallel to the levee (Figure 21). The second survey was a long survey that was also centered on the sand boil and oriented semi-parallel to the levee (Figure 22). The third and final survey was a long survey that was conducted crossing the sand boil but was not centered on the boil (Figure 22). Instead, the survey was oriented southwest-northeast and was centered to the northwest of SB-04 and SB-07, providing additional background coverage for the site.

Figure 21. View of short survey (shown in white) over SB7. Electrode

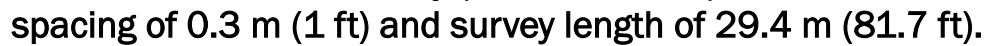

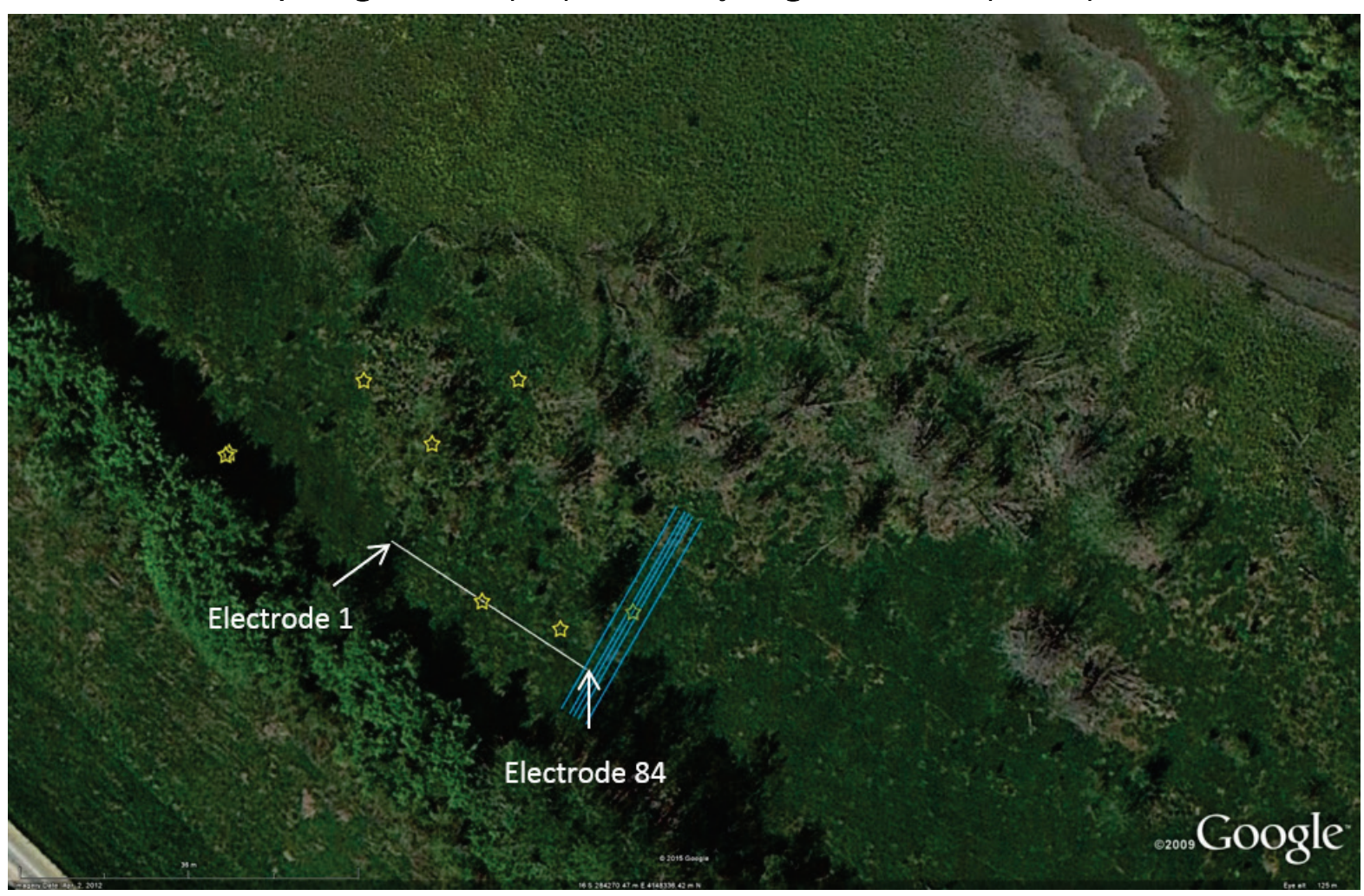


Figure 22. Two long surveys (shown in white) conducted over SB-07, each using an electrode spacing of $0.8 \mathrm{~m}$, resulting in a survey length of $66.4 \mathrm{~m}(217.8 \mathrm{ft})$.

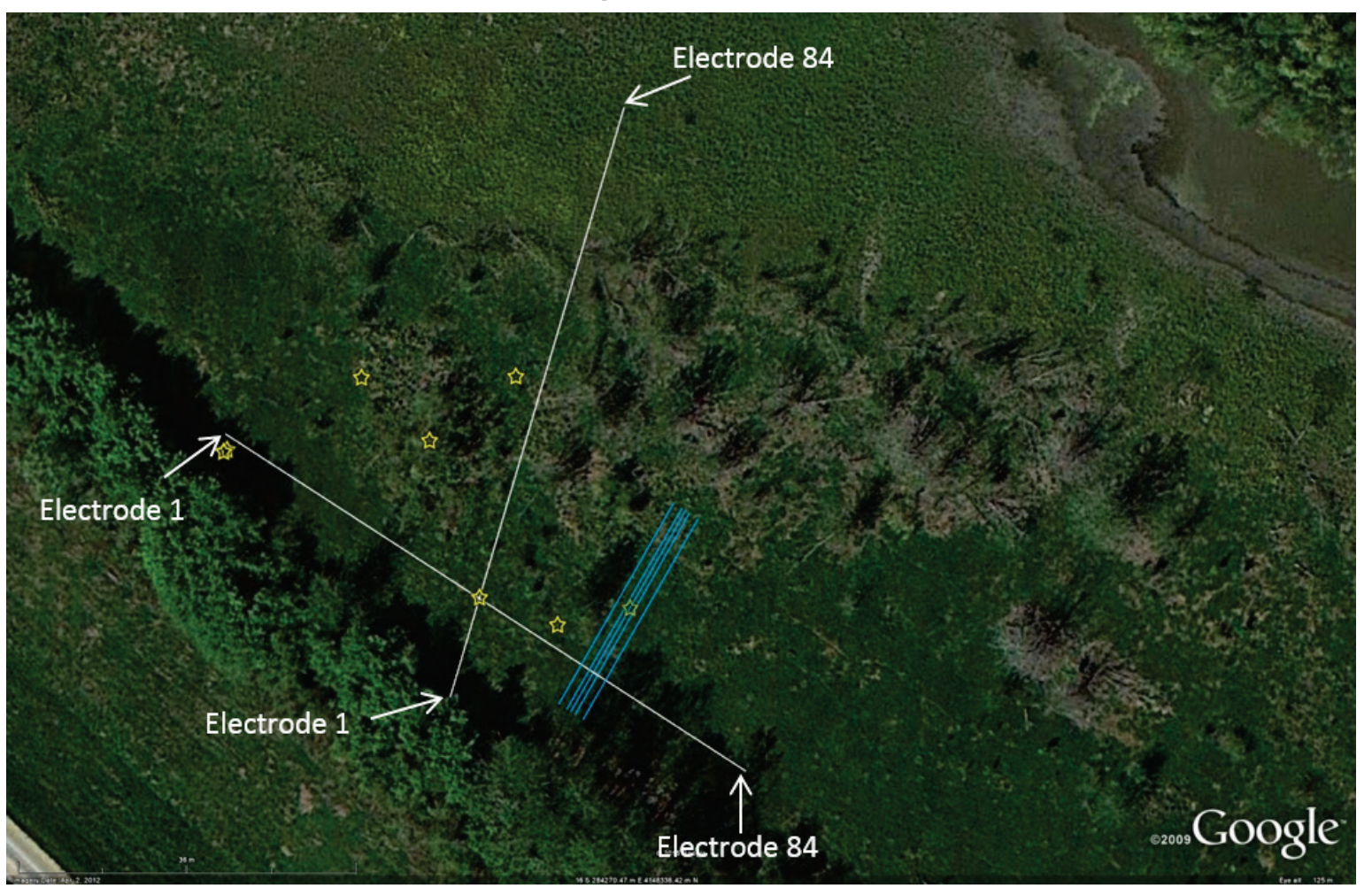

\subsection{CPT data collection}

CPTs were pushed following the ERT surveys to characterize the site and investigate/corroborate anomalous geophysical signatures. Additionally, selected split spoon soil samples were obtained by using CPT to verify soil types and to obtain grain-size data from selected horizons. CPT data collection began on 28 April 2015 and was completed on 2 May 2015. CPT collection was performed by the USACE Vicksburg District and ERDC personnel (Rusty Penley and Chris Collins, USACE Vicksburg District, and Julie Kelley, ERDC-Geotechnical and Structures Laboratory). The CPT truck that was used was a 15-ton Hogentoggler system.

Twenty-four CPTs were pushed (Figure 23). CPT logs are presented in Appendix B. The truck was unable to sample some areas due to limited site access. All CPTs were grouted after completion (Figure 24). CPT locations were selected to investigate the subsurface stratigraphy between the levee and the sand boil area as well as directly beneath two of the sand boils. Eight deep CPTs were pushed to depths of $38 \mathrm{ft}(11.6 \mathrm{~m})$ to $50 \mathrm{ft}(15.2 \mathrm{~m})$ to determine both blanket and aquifer characteristics. Eight CPTs were 
pushed in the sand boil area on 29 April 2016 to determine sand boil properties. Figure 23 shows the locations of all CPTs that were pushed in relationship to the ERT lines and the sand boils.

\subsection{Sand boil properties}

Dimensions of the larger sand boils studied at the Preston site are presented in Table 1 and shown in Figure 25. The larger sand boils were consistently between $50 \mathrm{~cm}$ (19.7 in.) to $60 \mathrm{~cm}$ (23.6 in.) in height, but their diameters varied, as shown by Table 1 . These large sand boils were on top of a natural clay wetland soil. Sand that had moved from the aquifer to form the boils contrasted in color and texture to the black clay wetland soil. This color and texture contrast provided an excellent opportunity to study subsurface erosion and basic sand boil geometry. Subsequent sampling of sand boil soils was accomplished in their dry state.

Surface soils in the sampling area are classified under the U.S. Department of Agriculture (USDA) soil taxonomy as being wetland soils and by the Web Soil Survey (USDA 2015) as the Medway silty clay loam (CL in the USCS), with an average thickness of $80 \mathrm{in}$. (203 cm). A typical profile has an upper layer of silty clay loam (CL) that is generally 25 in. $(63.5 \mathrm{~cm})$ in thickness and transitions to stratified loamy fine sand (SM) with depth. The natural soil was dark brown to black in color, and most areas were covered with grass and small willow trees. 
Figure 23. CPT locations (red), ERT lines (blue) and sand boil locations (yellow).

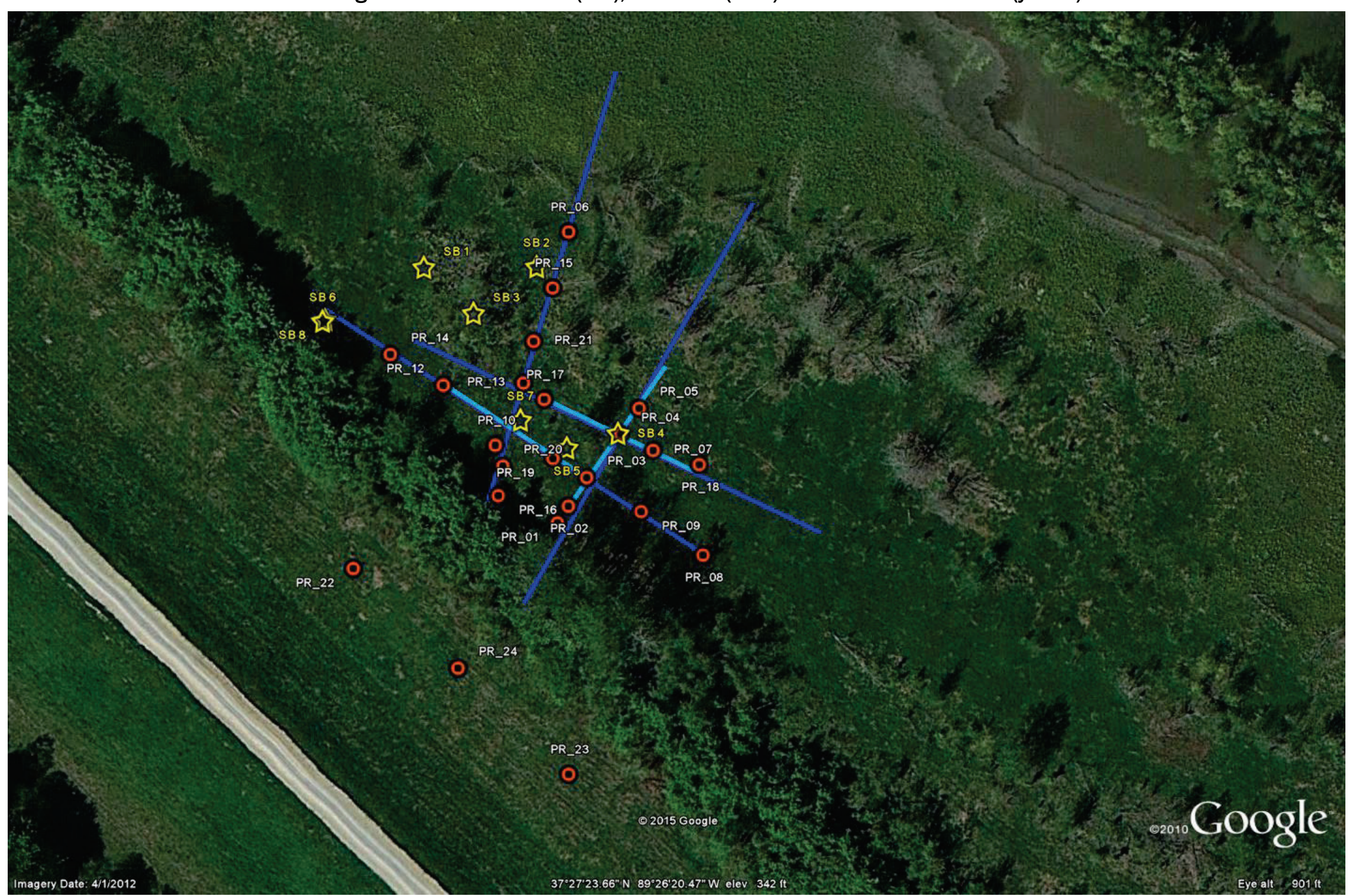


Figure 24. Researchers grouted all boreholes before leaving the study site.

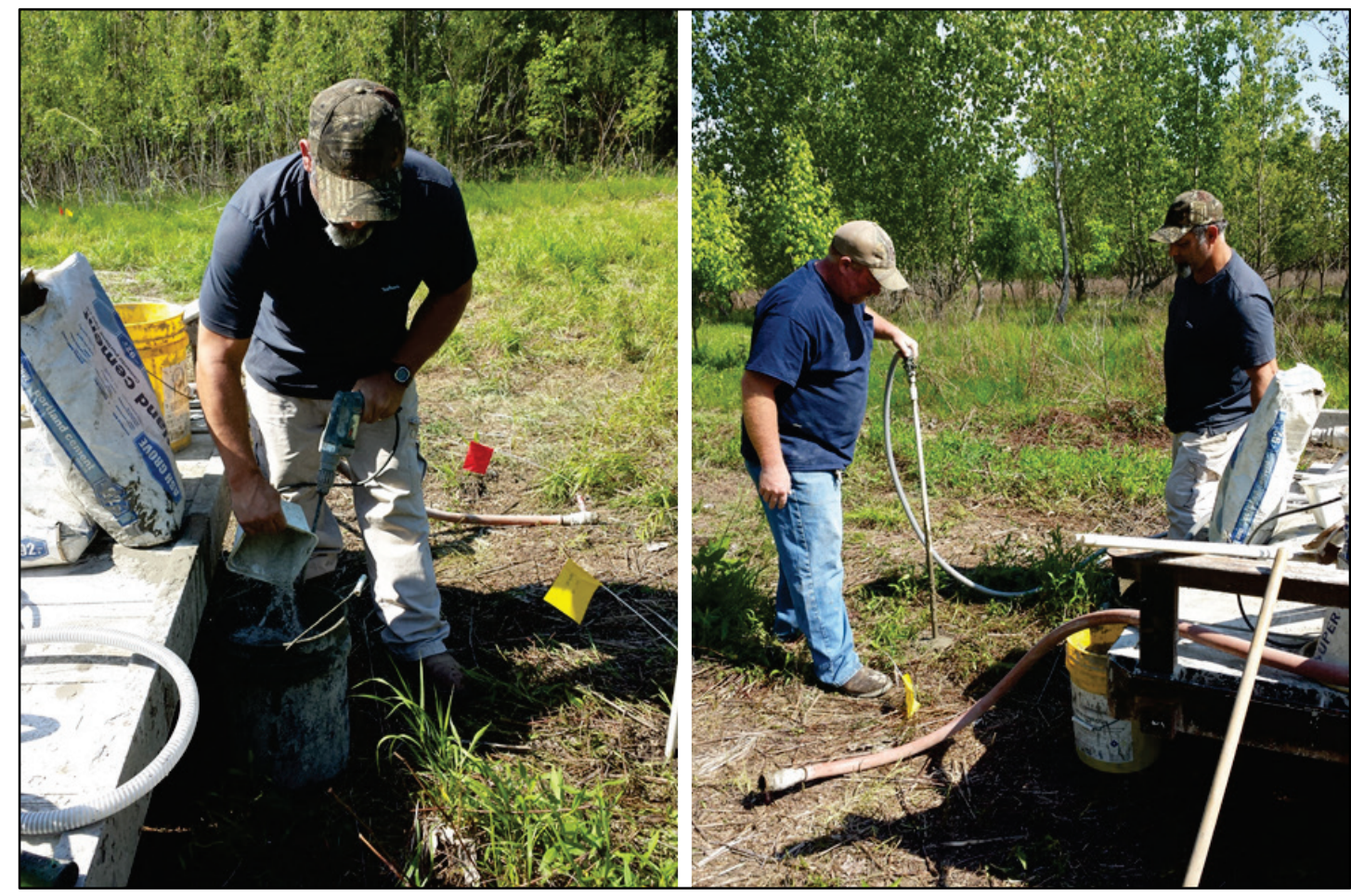

Table 1. Dimensions of selected sand boils.

\begin{tabular}{|c|c|c|c|}
\hline \multicolumn{4}{|c|}{ Preston (PR) Sand Boils } \\
\hline Name & $\begin{array}{l}\text { Diameter, } \\
\mathrm{m}(\mathrm{ft})\end{array}$ & $\begin{array}{l}\text { Height, } \\
\text { cm (in.) }\end{array}$ & Comments \\
\hline SB-01 & $5.9(19.4)$ & $55(21.6)$ & $\begin{array}{l}\text { Double sand boil, with larger boil to the } \\
\text { west. Excavated by hand. }\end{array}$ \\
\hline SB-04 & $3.7(12.1)$ & $60(23.6)$ & $\begin{array}{l}\text { Sampled with split spoon } \\
\text { (Mississippi Valley No. PR-15-04) }\end{array}$ \\
\hline SB-05 & $2.3(7.5)$ & $30(11.8)$ & \\
\hline SB-07 & $3.8(12.5)$ & $50(19.7)$ & $\begin{array}{l}\text { Sampled with split spoon } \\
\text { (MVN-PR-15-19) }\end{array}$ \\
\hline
\end{tabular}


Figure 25. Sand boils in the sampling area.

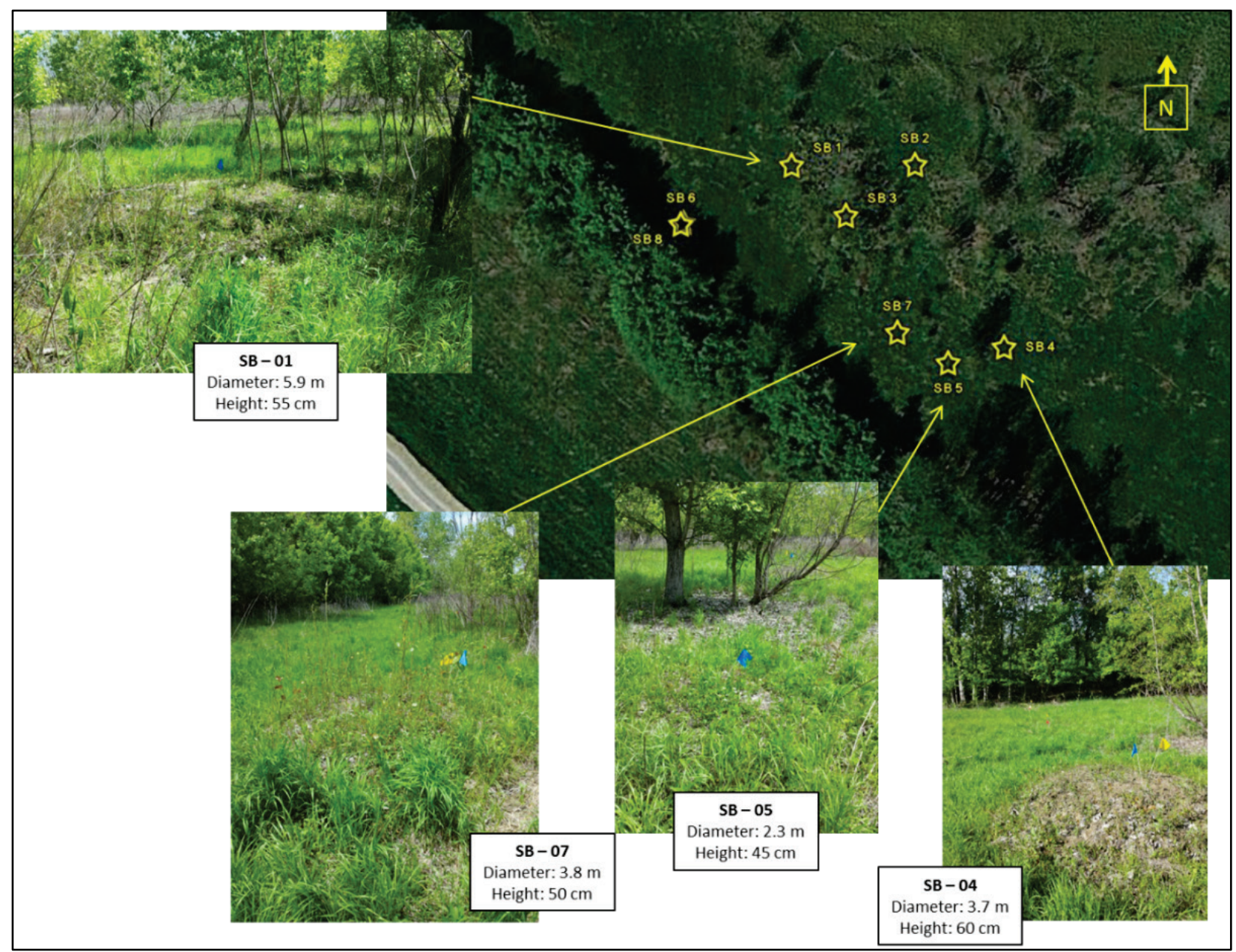

The clay blanket in the sand boil area is about 10 to $12 \mathrm{ft}$ ( 3 to $4 \mathrm{~m}$ ) thick and transitions into a sand or silty sand; however, the blanket at the levee toe was not as thick, about 7 to $10 \mathrm{ft}(2.1$ to $3.0 \mathrm{~m})$ in thickness. Most CPTs were able to penetrate to $50 \mathrm{ft}(15 \mathrm{~m})$ before refusal. A few of the CPTs showed a weakened, weathered layer at the blanket/substratum interface. Split-spoon samples were taken from the weathered zone in CPT borings No. 4 (in SB-04), No. 5 (behind SB-04), No. 24 (in the levee toe), and No. 19 (between SB-07 and levee). Mica was noticeably present in some of the split-spoon soil samples (SB-04 at 6-ft [1.8-m] depth) and also present in the excavated sand boil (SB-01) in some layers. Logs from split spoon samples are presented in Appendix C, and laboratory grain-size data are presented in Appendix D. 


\subsection{Sand boil excavation}

A trench was excavated through the center of SB-O1 to the original wetland surface to characterize its internal structure. A "neck" was identified where the sand had erupted through the wetland clay soil (Figure 26). Further excavation of the neck revealed the sand below was not in a conduit form but instead was in lobes (Figure 27). Two areas were revealed where sand had come through the darker colored wetland soil, representing two seepage pathways forming the sand boil. Deeper excavation below the wetland soil surface revealed that these necks were not positioned as a single vertical conduit. The sand moved upward through the subsurface, following the path of least resistance and leaving irregular masses of sand connected by narrow channels (Figure 27).

Figure 26. SB-01 was excavated to reveal two "necks" where sand had erupted through the dark wetland soil below.

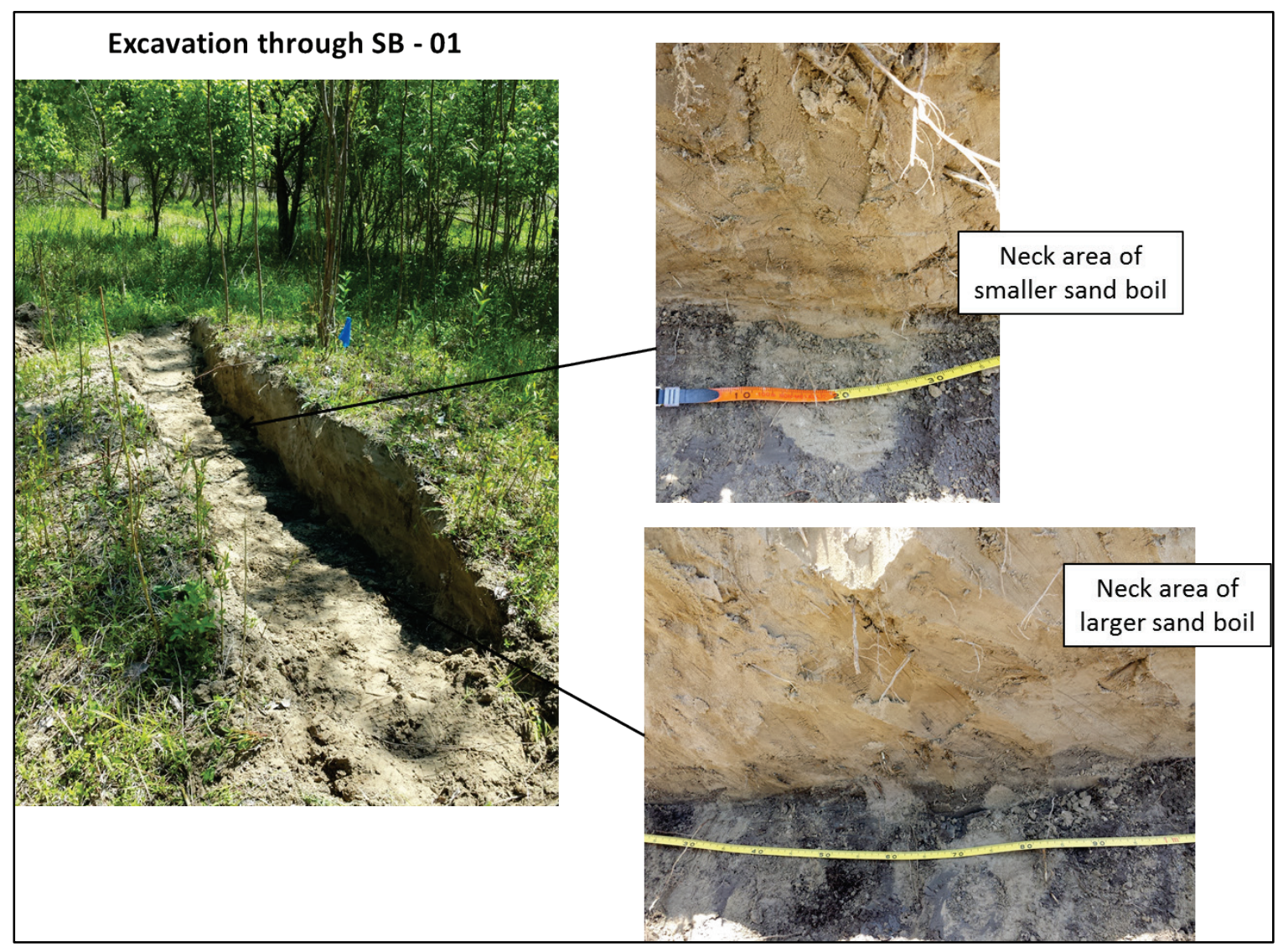


Figure 27. Irregular masses formed in the subsurface as the sand moved upward.

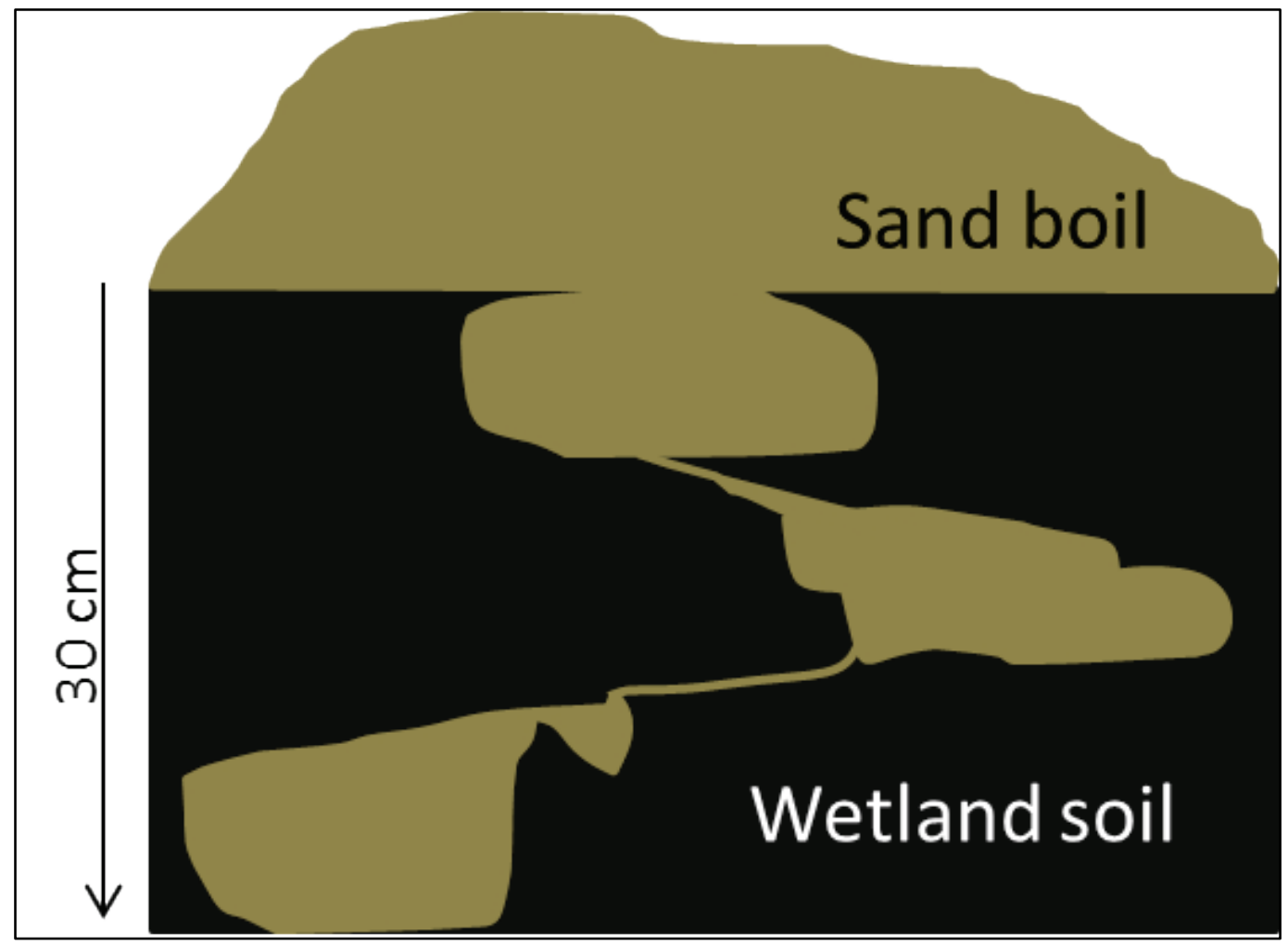

Sandy soil in the trench wall was laminated, as shown by Figure 28. Layers vary from coarser-grained sand with iron staining to finer-grained silt and sand. Mica is visible in some layers in the trench but not in others. The presence of iron staining and laminations indicates periodic submergence by seepage and episodic sand boil development. This particular boil has been active for several years as reflected by the fine sand that was present throughout this area at the surface. 
Figure 28. Soil in the trench wall of the sand boil is laminated.

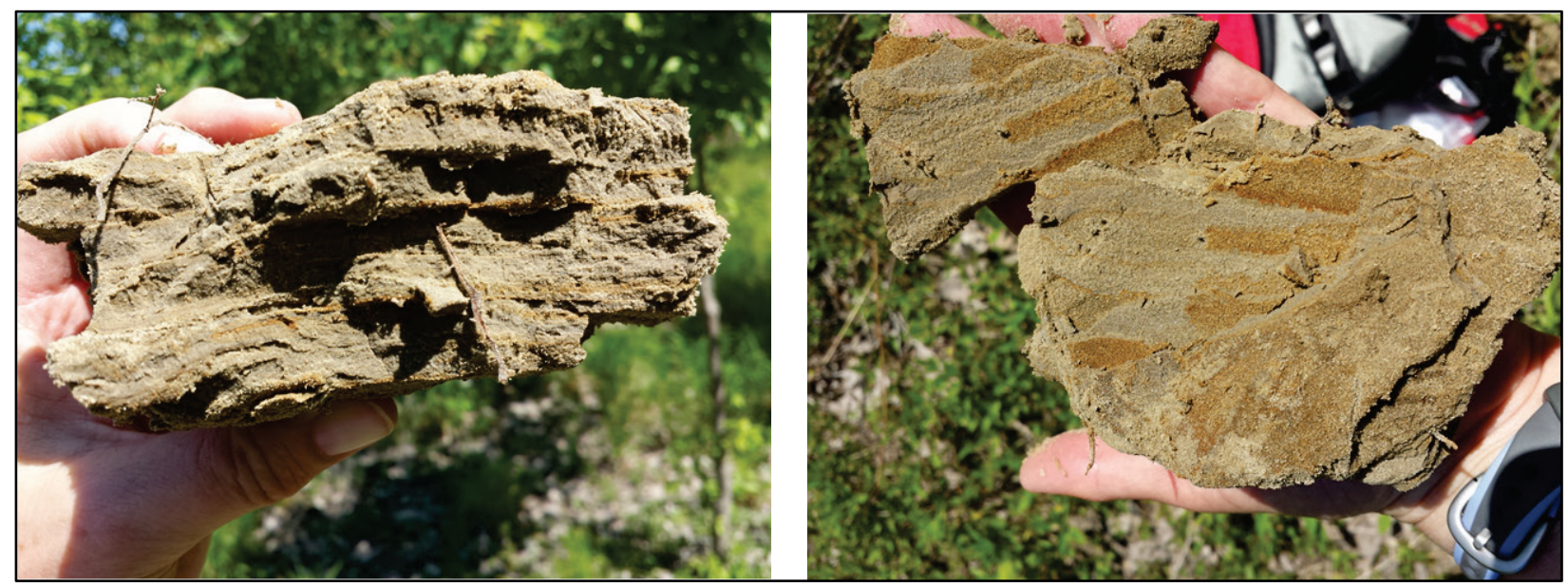

\subsection{January 2016 Flood observations}

A return visit to the Preston boil site was made on the morning of 3 January 2016 near the peak of the January 2016 Flood crest. The levee district had raised the tailwater in this area through use of a portable pump to lessen the hydraulic gradient acting in this reach (Figures 29 and 30). The presence of standing water in this low-lying area due to underseepage and emergency pumping highlights active processes that are involved in sand boil development. These features often form under submerged conditions with cone height at the level of the maximum water depth. Thus, the large boil that is shown in Figure 3 was likely formed under submerged conditions with the tailwater level near this elevation. 
Figure 29. View of low-lying sand boil area behind the levee during the January 2016 Flood.

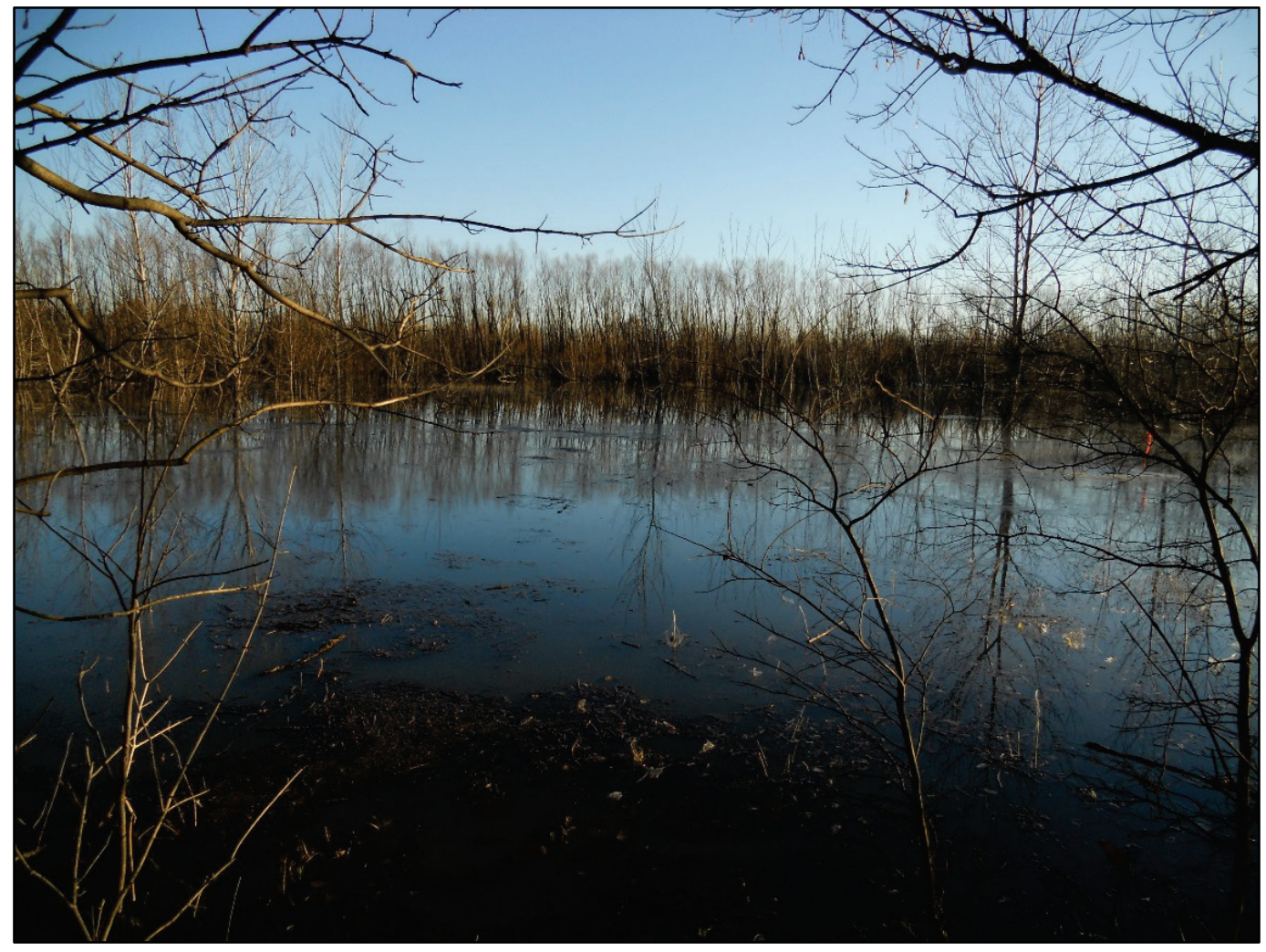


Figure 30. Pumping of water to the Preston sand boil area to raise the tailwater (see Figure 29).

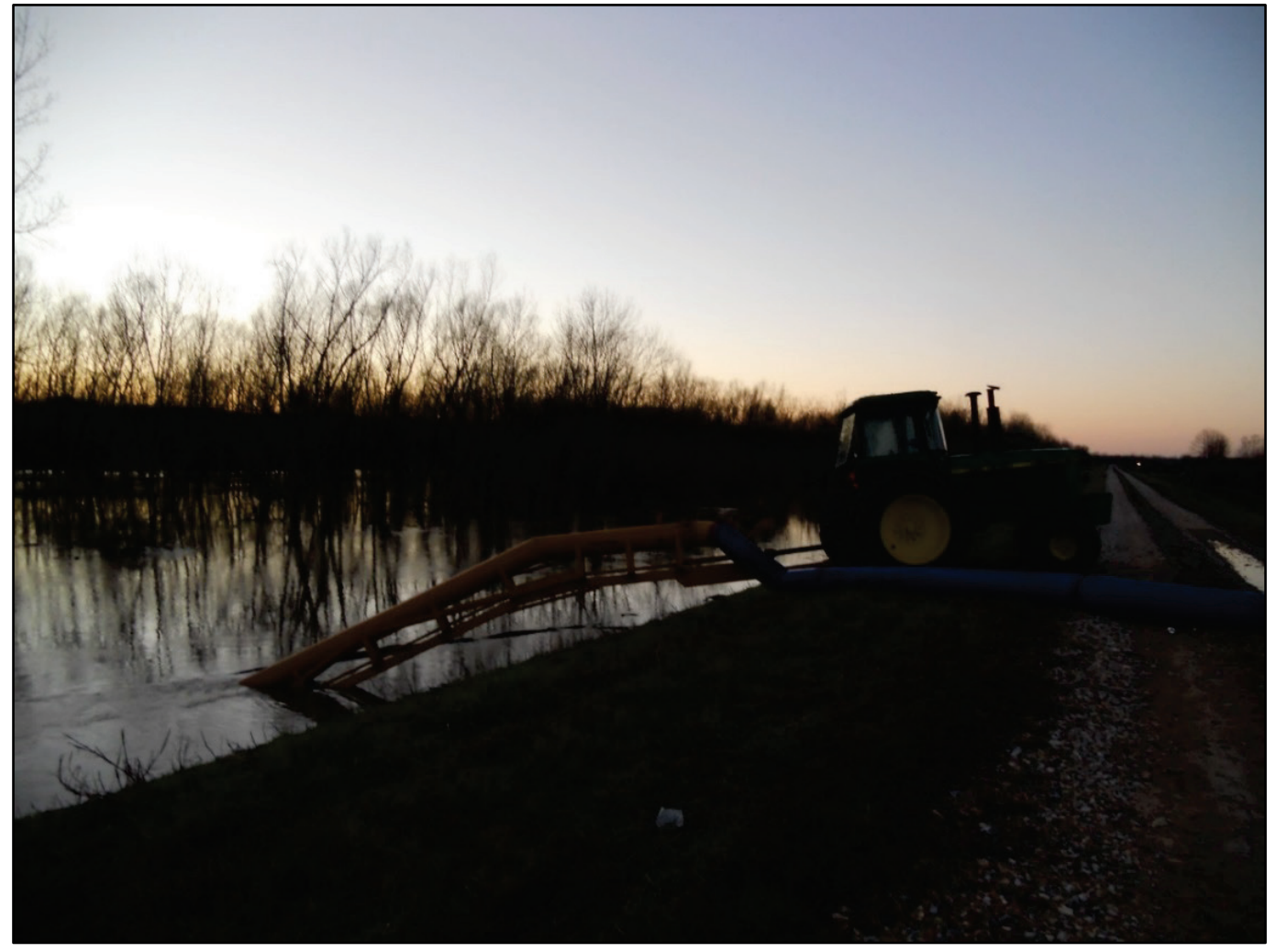

\subsection{Groundwater data}

Specific groundwater elevations in the alluvial aquifer from the Preston site and the onset of sand boil formation in 2013 at this location can only be inferred after the fact, as no piezometers were present in this reach prior to 2014 to monitor groundwater elevation. The USACE St. Louis District installed three piezometers at the Preston site in 2014 for the purpose of obtaining continuous groundwater data at this site. Three piezometers were installed in the alluvial aquifer at the floodside and land side toe of the levee and in the crest (Figure 31). Each of these piezometers contained automated pressure transducers to measure hourly changes in groundwater elevation during a flood cycle. From the piezometer data at this location, it is possible to estimate historic groundwater conditions in relationship to river stage and better understand past sand boil activity. A plot of river stage and groundwater values from November 2014 to March 2016 is presented in Figure 32 (USACE MVS data, courtesy of Jeremy Eck, Dam and Levee Safety Section). 
Figure 31. Piezometer at levee crest with automated water level recorder that measured groundwater levels during the 2016 Flood.

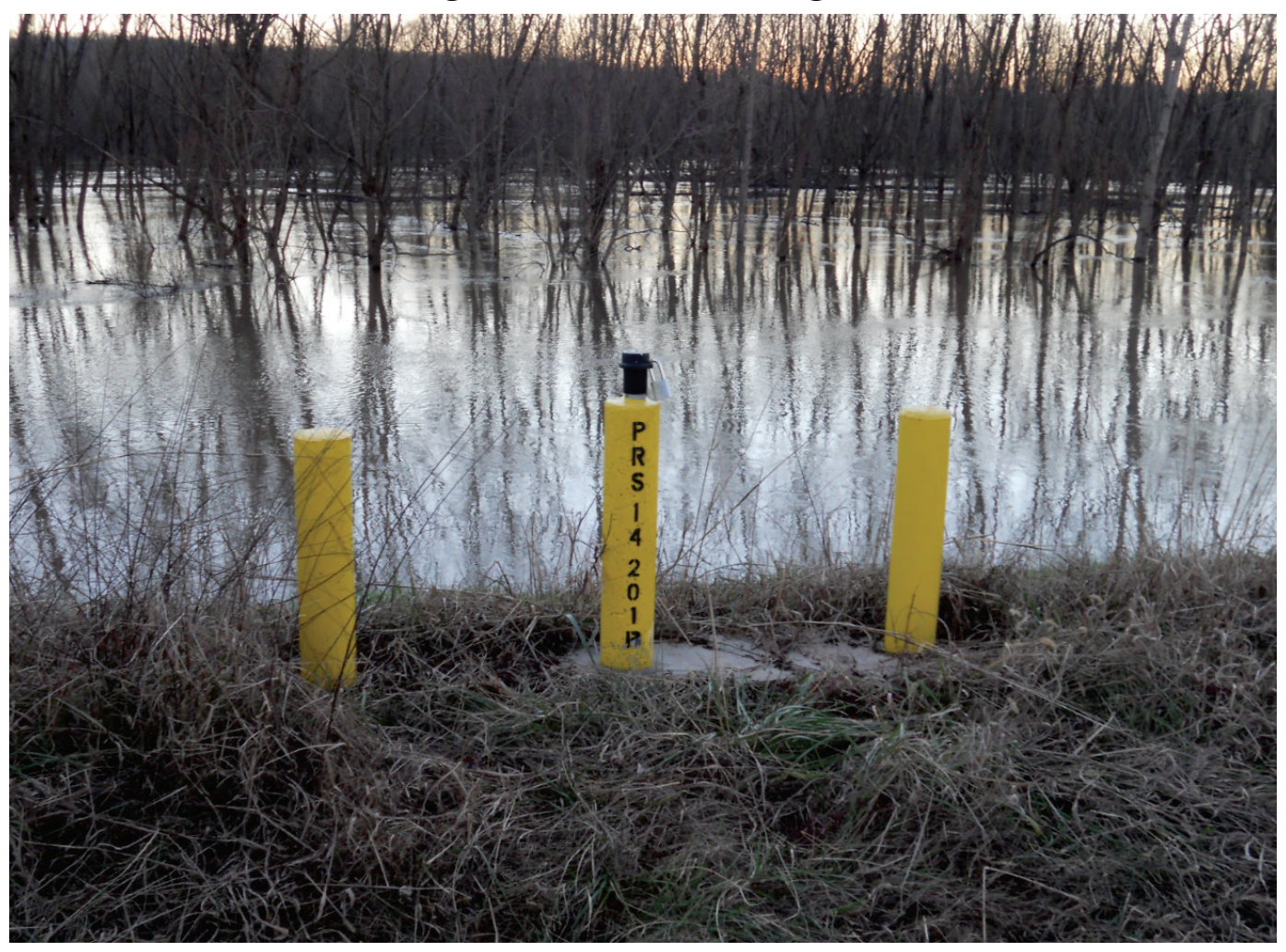

Based on the graph in Figure 32, it is possible to reconstruct past river stage and groundwater levels shown in Figures 29 to 31. For this example, the peak flood stage occurred on 1 January 2016 at $0100 \mathrm{hr}$, with a reading at $372.38 \mathrm{ft}(113.5 \mathrm{~m})$, according to the Grand Tower gage. Flood photos shown in Figures 29 to 31 were taken two days after the flood peak. Thus, the river stage and groundwater levels for the three piezometers at this time are easily reconstructed from instrumented data.

\subsection{Comparison of the 2016 and 1993 floods}

A comparison of the January 2016 Flood to the 1993 Flood is presented in Figure 33 for the Grand Tower to Cape Girardeau reach. The January 2016 Flood ranks comparable to the 1993 Flood, but it was still below the design flood event the levees had been built to withstand. As shown by the height of the river in Figure 31, the water level was near the peak for this flood. The study site is near river mile 66 with estimated peak at $364 \mathrm{ft}$ during the 2016 Flood (Figures 8 and 32). 
Figure 32. Graph of river stage and groundwater levels from November 2014 through the January 2016 Flood. (Piezometer data courtesy of Jeremy Eck, USACE St. Louis District, Dam and Levee Section).
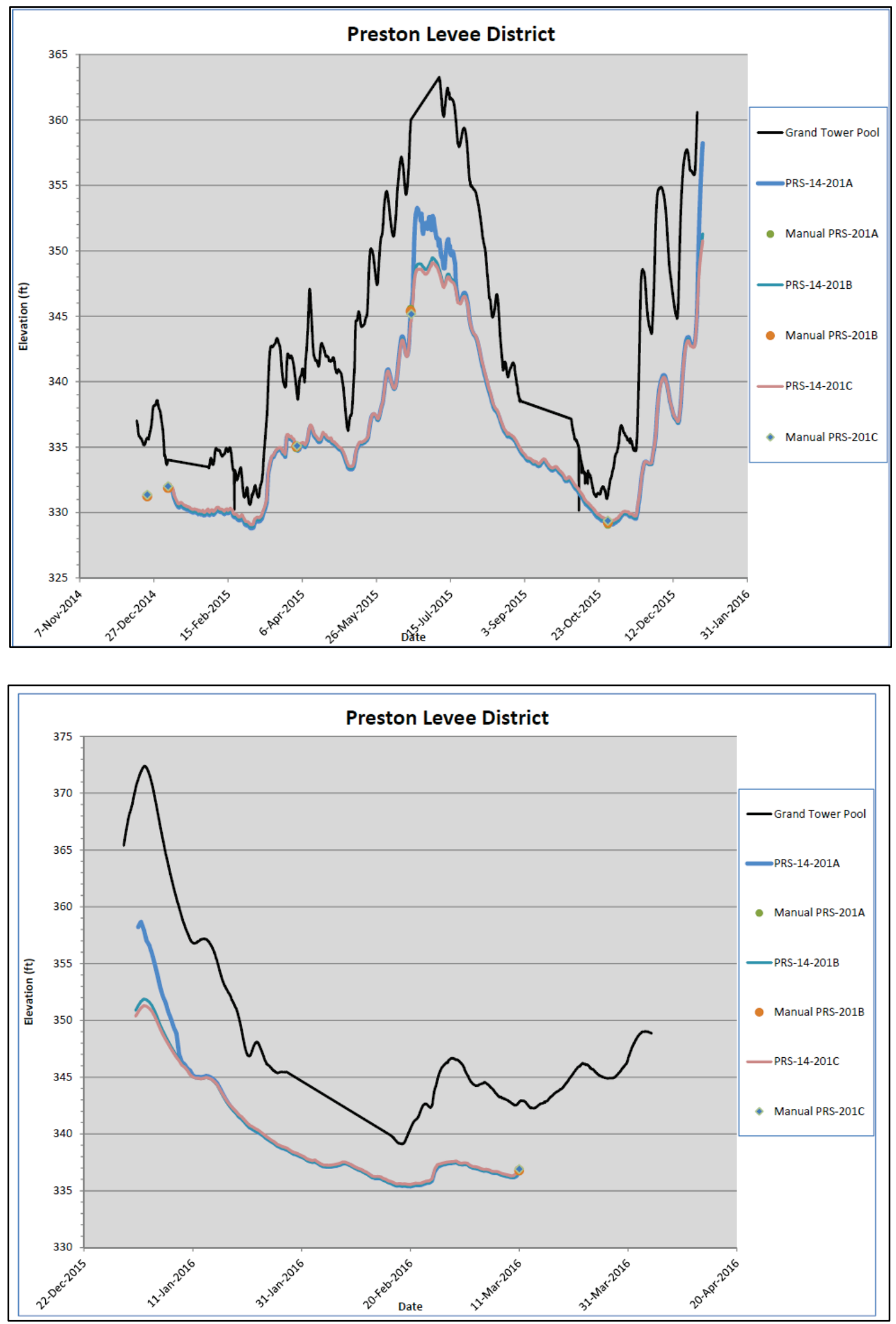
Figure 33. Comparison of the 2016 Flood to past floods and design flood (USACE 1994).

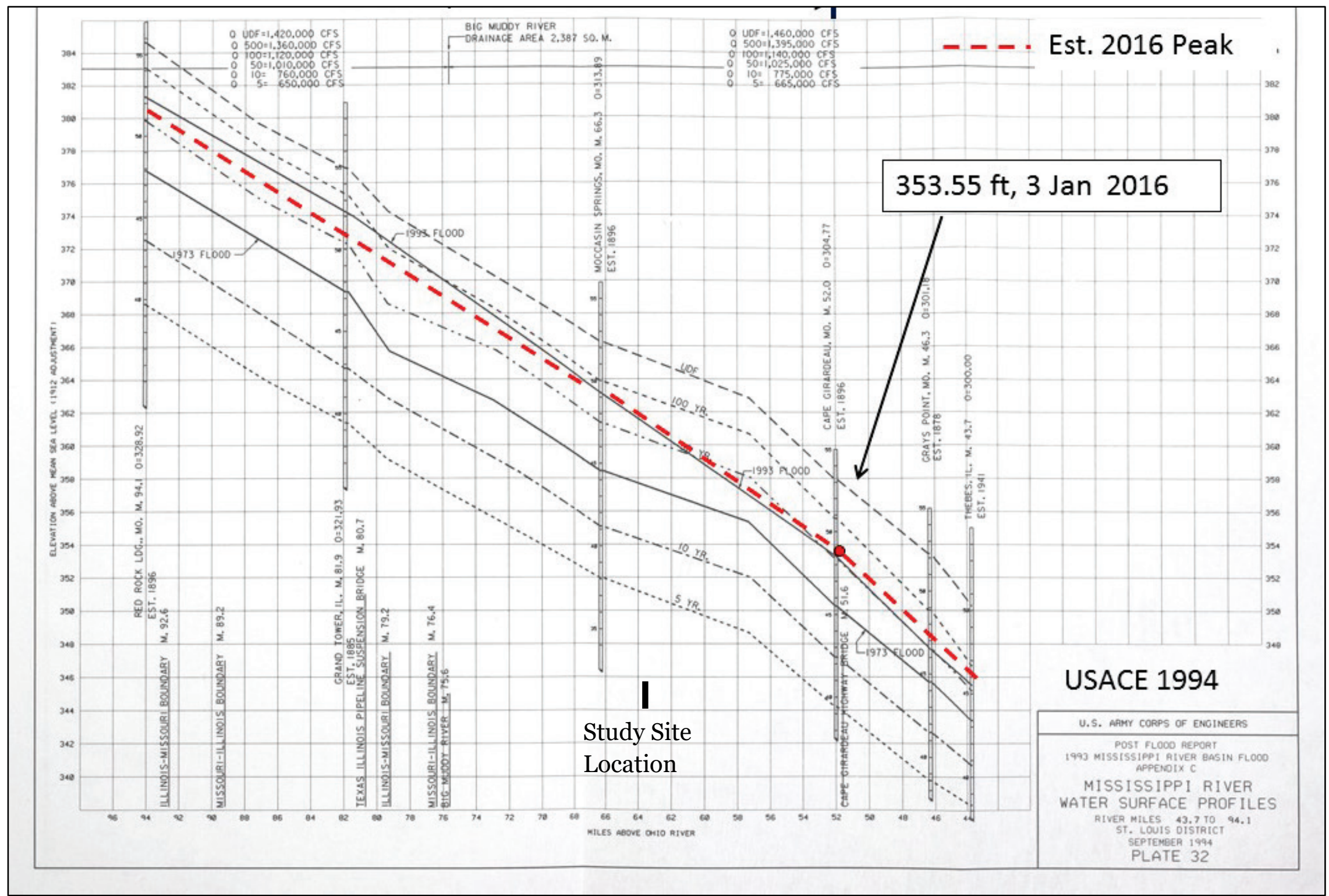




\subsection{Field data summary}

This chapter has presented an overview of the site conditions at the Preston site and the field data that were collected to address the nature of sand boil activity at this site. The next chapters of this report will provide detailed discussion of the geology and hydraulic conditions to evaluate the sand boil development and address the research objectives previously identified in Chapter 1. 


\section{Electrical Resistivity Tomography (ERT) Results}

\subsection{Introduction}

This chapter presents the results of the ERT data that were collected from the Preston site. The focus for the data collection was to characterize the underlying stratigraphy of the site and the larger sand boil locations. Important to this effort was an understanding of the soils that comprise the stratigraphy, the thickness of these different units, their lateral extent, and their engineering properties. ERT data are described and presented first because these data were collected before any site disturbance occurred. Signatures identified by ERT surveys were then investigated with CPTs, and selected soil sampling was performed to investigate/corroborate the ERT results.

\subsection{ERT modeling software and results}

ERT surveys were made on two separate occasions at the Preston site: 23-25 September 2014 and 31 March to 01 April 2015. RES2DINV inverse modeling software by Geotomo Software was used to process all the resistivity data. The software inversion process uses the individual resistivity measurements collected during a survey to produce a 2-D resistivity profile or inverse model resistivity section of the subsurface. Resistivity surveys by convention are typically performed by using metric or the International System of Units (SI) units, with measurements reported in ohm-m. Consequently, the discussion that follows will incorporate both SI and corresponding English units.

\subsection{Inversion}

An inversion represents a nonunique mathematical model or solution from the resistivity measurements that were made. The model attempts to estimate the limits of the underlying electrical current flow, which is related to inherent properties of the soil, mainly texture, mineralogy, and moisture in the pore spaces. Electrical current flow in soils involves movement of electrons by direct contact (conduction) and ionic charges (ionic conduction) in the aqueous fluids. The inversion process divides the earth into a discrete number of cells by a gridding process with the possibility of more cells than actual (unique) data values being measured. Hence, the 
profile that is produced is described as being an inverse model resistivity section and represents a best estimate, mathematic model or solution to the half-space measurements made during the survey. The inverse model resistivity section (from here on referred to simply as a resistivity section) is often viewed as being an approximation of a stratigraphic or geologic model for the resistance to current flow in the underlying earth. This model generally relates to the soils and stratigraphy present.

\subsection{Survey resolution}

Each of the survey lines collected at the Preston site was individually processed, resulting in 2-D resistivity sections. The purpose for closely spaced survey lines was to observe the subtle changes that occur between the different survey lines and between the individual electrodes themselves. An important concept for geophysical data sets involves target resolution and the number of measurement points needed to discriminate a target of interest from the background media.

An analogous concept in resolution occurs in image processing and the idea of pixel resolution involving imagery to resolve features of interest. Ideally, multiple measurements of the target of interest are required from the measurement field to discriminate features and subtle characteristics about the target. For imaging sand boils, being able to discriminate the size, shape, direction, and orientation of the underlying stratigraphy is of interest to this study.

\subsection{Depth penetration}

High-resolution ERT imaging requires closely spaced electrodes $(30-\mathrm{cm}$ (11.8-in.) spacing at Preston) and closely spaced interline surveys $(0.5 \mathrm{~m}$, (1.6 ft)) used to characterize subsurface features in any detail; however, one of the limitations of high-resolution surveys is the shallow depth of penetration. For the short survey lines (30-cm (11.8-in.) electrode spacing), the depth of penetration is on the order of 5 to $6 \mathrm{~m}$ ( 16 to $19 \mathrm{ft}$ ). To overcome the shallow depth of investigation, wider electrode spacing is used to image deeper into the subsurface (long surveys). Hence, both short and long surveys were performed at the Preston site.

Long surveys at Preston incorporated a $0.8-\mathrm{m}$ (2.6-ft) electrode spacing to image to a greater depth. The depth of investigation for long surveys performed at the Preston site is on the order of 15 to $16 \mathrm{~m}$ ( 49 to $5^{2} \mathrm{ft}$ ), 
which permits imaging through the blanket and into the upper alluvial aquifer. Deeper surveys would need to incorporate an electrode spacing of 2 to $3 \mathrm{~m}$ (6.5 to $9.8 \mathrm{ft}$ ) in order to image to the top of rock (Figure 7); however, deep surveys to rock were not performed at Preston because the primary focus of this study was characterization of sand boils in the blanket and upper aquifer.

\subsection{ERT data and presentation of resistivity sections}

Before presentation and discussion of individual ERT resistivity sections, it is first appropriate to list the geologic parameters of interest to this study. These include the blanket or top stratum thickness, its lateral extent, characteristics of blanket and aquifer soils, extent of the vertical and horizontal stratigraphy, and the presence of abrupt discontinuities due to local changes in depositional environment, defects in the blanket, and/or disturbances caused by sand boil activity, which would locally affect the blanket resistivity values.

The resistivity section for the long survey (o.8-m (2.6-ft) electrode spacing) conducted over SB-04 in September 2014 is presented as Figure 34a. This section extends perpendicular to the levee from the land side toe, as shown by the accompanying photograph in Figure 34b. Specific characteristics about the resistivity section are described first to familiarize the reader with fundamental display properties, before any technical discussion occurs on the individual survey results. This background information is appropriate to all the sections presented in this discussion and ensures basic understanding of the ERT section and the results.

Electrodes in an ERT survey are individually numbered, with electrode position no. 1 at the left edge of each section. Electrode 1 is located at the levee toe in Figure 34b, and electrode 84 is farthest from the levee. Specific locations in the section are referenced throughout the ERT discussion regarding soil texture and stratigraphic characteristics based on their position in meters relative to electrode 1 . The distance scale is presented at the top of each section from the survey origin (electrode 1).

The northeast trending section has a logarithmic color scale, and the values are in ohm-m. Because of the logarithmic color scale that was used for display, the range in values is nonlinear. Thus, the range in values and associated color bins for resistivity in the section in Figure 34a are not 
equal in terms of their distribution and the classification of the resistivity interval; however, the different resistivity sections that are presented throughout this discussion all use a consistent color table for illustration of the resistivity contrast. By convention, low resistivity (high conductivity) values are usually represented by dark blue to blue colors, while higher resistivity (low conductivity) values are typically displayed as being orange to red in color.

Figure 34a. September 2014 long-line resistivity section over SB-04.

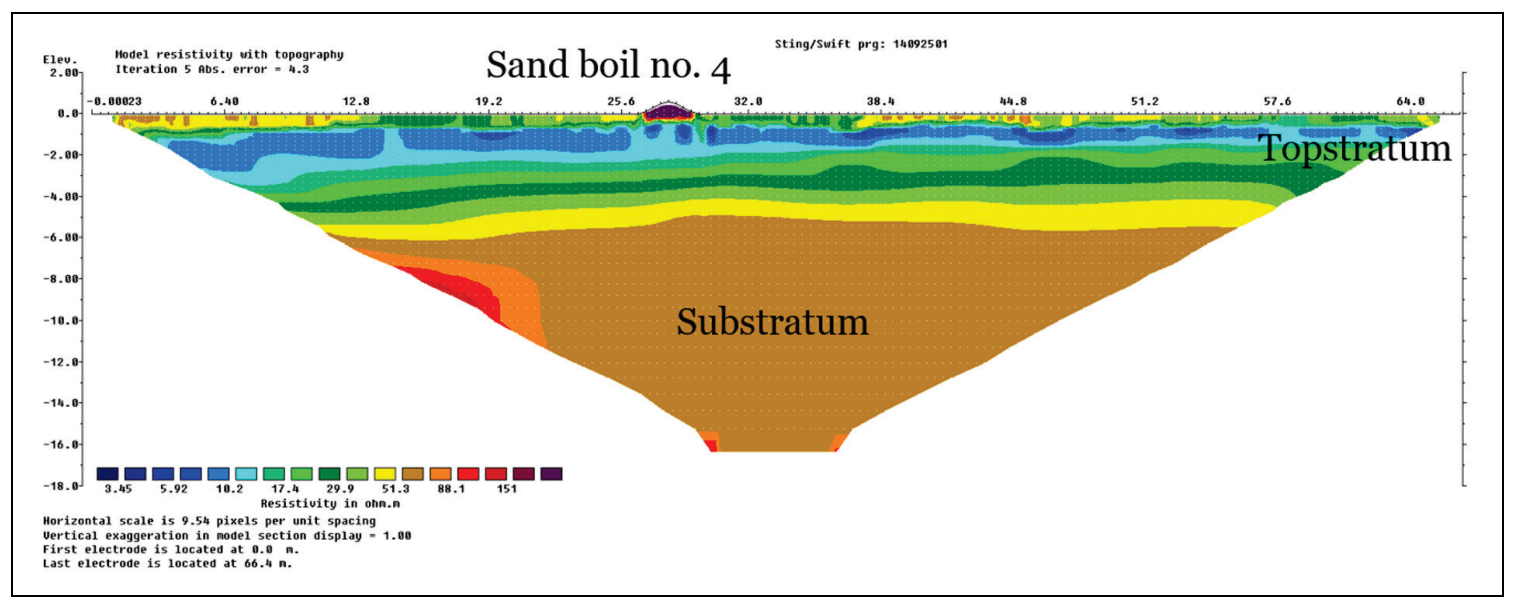

Figure 34b. Long ERT survey over SB-04.

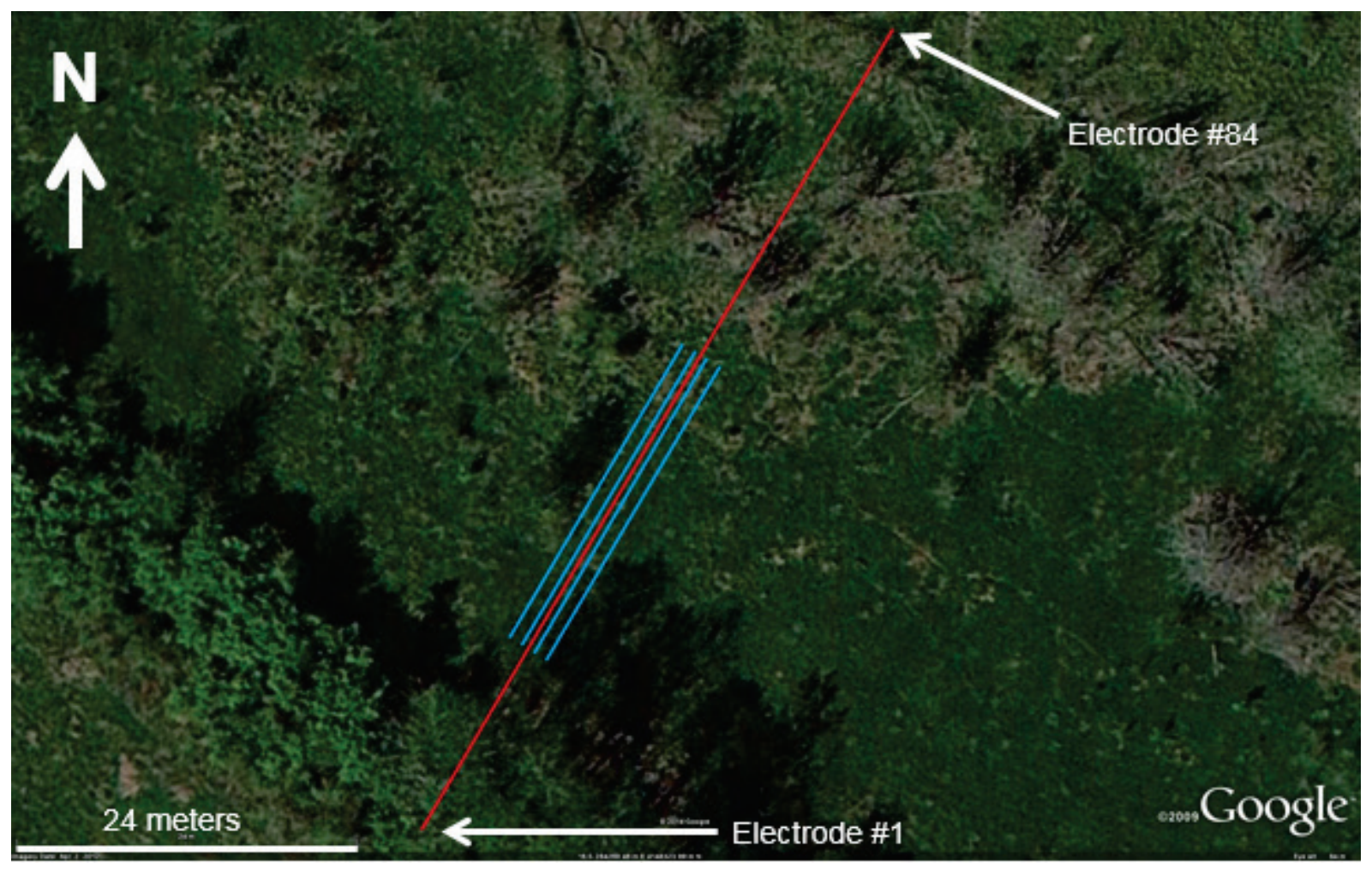


This interpretive color scheme has been used as a proxy for soil type based on long-term empirical experience gained by using this method. Thus, fine-grained, clay-rich soils are normally conductive (blue), while coarsegrained sands and gravels are normally highly resistive (red). The middle range in resistivity values (green, orange, and yellow) generally favors a mix of different soil texture (silts, sandy silts, silty sands) that are intermediate between the fine- and coarse-grained end members. Additionally, groundwater chemistry and soil moisture can significantly affect the typical response, especially for fine-grained soils that are dry and desiccated, which can display a highly-resistive signature due to effects of extreme moisture loss.

\subsection{Sand Boil No. 4}

The resistivity section in Figure 34a across SB-04 extends to a maximum depth of investigation of $\sim 16.5 \mathrm{~m}$ ( $54 \mathrm{ft}$ ). The long section identifies a welldefined top stratum and the presence of a deeper, resistive substratum. The blanket is 4 to $5 \mathrm{~m}$ ( 13 to $16 \mathrm{ft}$ ) thick in this section. The top stratum and substratum interface is in close agreement with the geologic data that were presented in Figure 7.

Horizontal current flow (layering) in the top stratum contains measurable discontinuities in the resistivity values directly below the boil area, which extends to a depth of $\sim 2.25 \mathrm{~m}(7.4 \mathrm{ft})$. The large boil at this location has clearly caused a disruption to the apparent horizontal layering that is present in this area. However, boil activity is not readily observed below

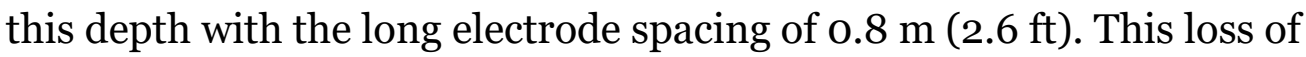
resolution may be the result of the larger volume that is being integrated for modeling of the deeper subsurface with the coarse electrode spacing. However, resolution of pipes or chimneys through the blanket would be better resolved with the use of shorter survey lines, which are described next. Thus, smaller electrode spacing permits higher resolution of the shallow blanket as previously described.

Features of note in the long-line survey in Figure 34a involve the resistive surface layer (green and yellow) located to both sides of the boil and the prominent lower resistive layer (light to dark blue) below this surface layer. The resistive surface layer indicates either sandy and/or dry desiccated finegrained soils present. Visual observation during the reconnaissance and trenching phase of this study favors the presence of sandy soils due to coalescing sand boil ejecta and transported substratum soils into this area. 
This viewpoint is supported by the appearance of vertical "pipes" (light blue) at positions 14,25 to 29 , and possibly 57 to 60 from the resistivity section origin. Seepage pipes or pathways were observed by trenching as previously described (see Figures 26 to 28). The lower resistive layer (i.e., top stratum) thins with increased distance from the levee toe.

Locations and numbering of the closely spaced short-line surveys at SB-04 are presented in Figure 35. The resistivity section for the center short-line survey (line 3) is presented in Figure 36. This section clearly shows anomalous resistivity values below the sand boil consistent with the presence of fairly disturbed stratigraphy. This section shows the presence of high resistivity values (possible shallow substratum sands) between electrode positions 13 to 16 . These high values would indicate that pervious sands are relatively close to the ground surface, between 2 and $3 \mathrm{~m} \mathrm{(6.5}$ to $9.8 \mathrm{ft}$ ) deep. If these are sands, either they were transported by the large hydraulic gradients developed during previous flood event(s), or they correspond to a shallow sandbar that was formed by river migration. A third possible explanation is the high values at this location correspond to noisy data and data dropout, not sands. This last explanation is discussed further, following examination of the other two mechanisms presented.

The high resistivity signature interpreted as substratum sand close to the surface is similar on three lines: 2, 3, and 4, respectively (see Appendix E for all resistivity sections). The large substratum anomaly does not occur on the remaining two short-line surveys, lines 5 and 1 located just $1 \mathrm{~m}$ to the northwest and southeast of Figure 36 (center section). The two end surveys, however, still contain a high resistivity feature in the blanket between positions 12 and 13 (although less pronounced than on the central surveys 2, 3, and 4) consistent with a seepage pathway extending to the surface (Figure 37).

The localized anomaly identified by the three closely spaced surveys supports the interpretation of flood- and aquifer-related sand displacement as a mechanism, rather than the result of sand being formed naturally by lateral river migration processes and sandbar formation. The orientation of this feature in the three short-line profiles would likely be transverse to Mississippi River current flow, which lends support to an aquifer pressure transport model involving hydraulic fracturing of the blanket by seepage forces and the movement of substratum sand locally toward the surface under artesian pressure. 
Figure 35. September 2014 location of short-line surveys (0.3-m [1-ft] electrode spacing) at SB-04. Line 1 is farthest to the right (southeast) and line 5 is farthest to the left (northwest).

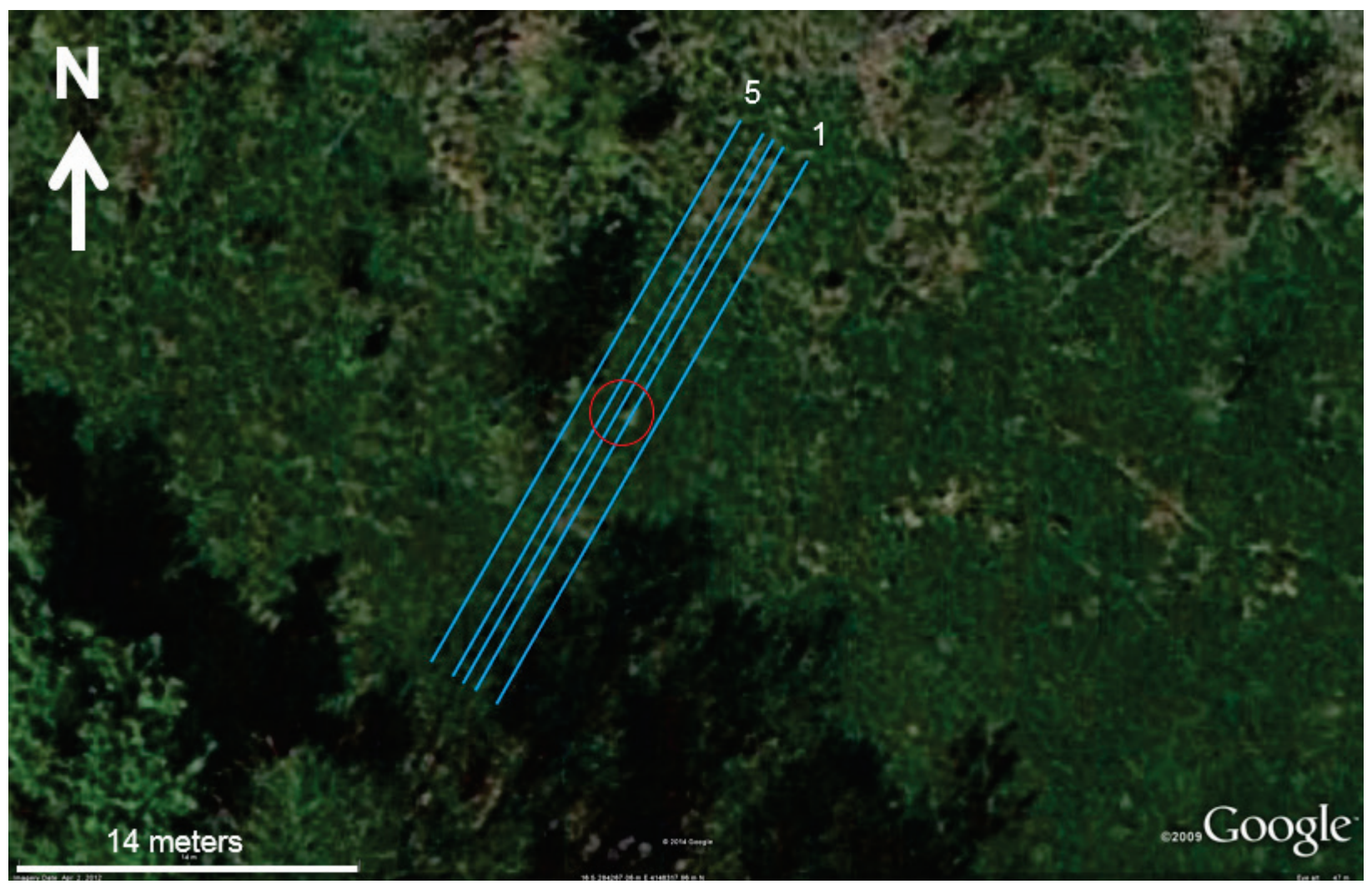

Figure 36. September 2014 short-line middle resistivity section crossing SB-04 in Figure 35.

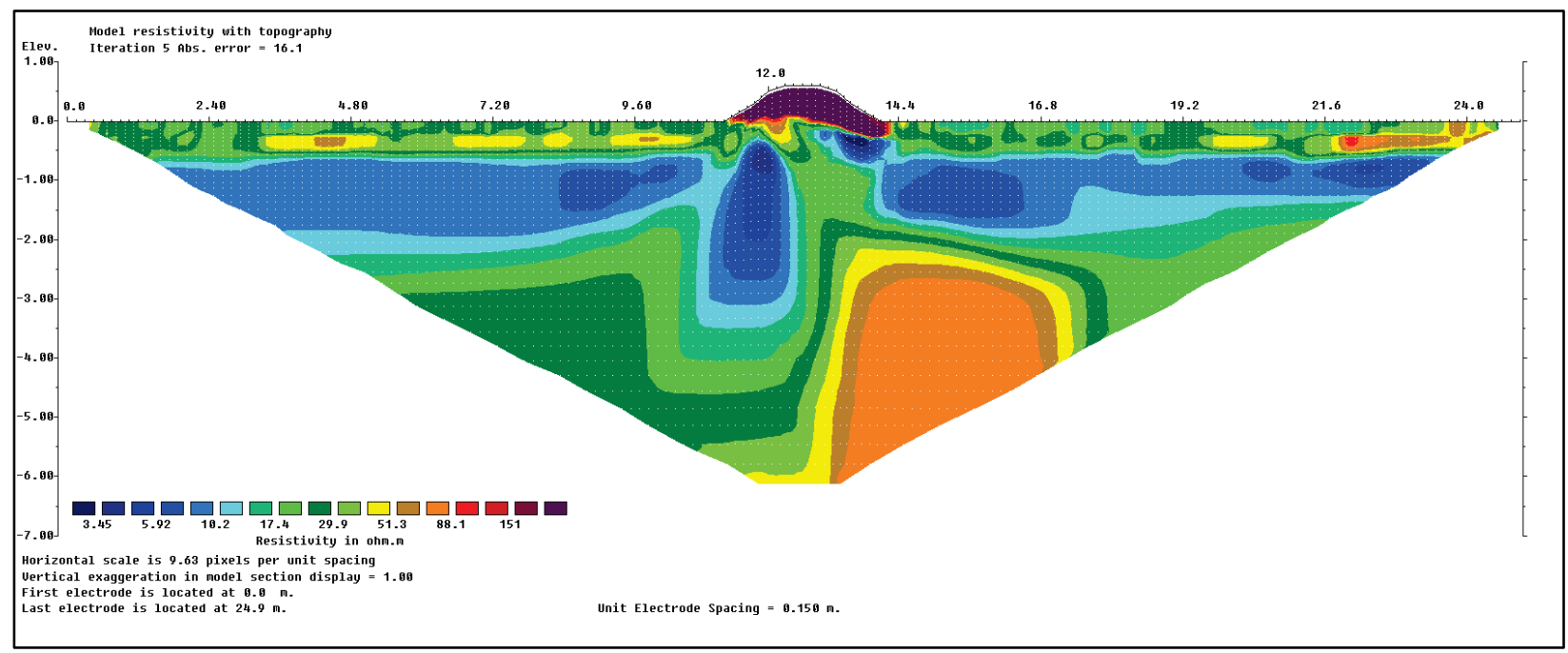


Supporting the aquifer pressure transport model is the presence of a resistive layer near the ground surface in Figure 37. This section is $29.4 \mathrm{~m}$ $(96.5 \mathrm{ft})$ in length and displays a well-defined resistive layer between a weakly developed conductive layer at surface and a thicker lower conductive layer. This resistive layer contains the presence of multiple high resistivity contrasts throughout this layer, signifying possible multiple sand pathways (pipes) being present. Additionally, and more definitively, there is a noticeable increase in resistivity values near the vicinity of SB-04 (positions 12 and 13) but not the large anomaly features that were observed in Figure 36.

A third explanation is briefly described here to account for the high resistivity contrast with the three short survey profiles over SB-04. This explanation involves data dropout from poor electrode coupling during the survey, which could produce high resistivity anomalies. However, this explanation would explain a single survey line but is considered rather unlikely with the coincidence of three closely spaced adjacent survey lines containing this same resistivity feature and signature. Additionally, the end survey lines contain a measureable contrast in resistivity in the blanket as shown by Figure 37, near the same position as SB-04, which would suggest disturbance with the blanket and/or the presence of a seepage pathway at this location from changes in soil moisture and/or texture. Thus, the third explanation due to data dropout is discounted here because this feature is present on multiple survey lines.

Repeat surveys were conducted at the end of March 2015 at the Preston site over SB-04. Two short-line resistivity sections are presented as Figures 38 and 39 (perpendicular to the levee at the same location as Figure 36 and parallel to the levee and across SB-04). Short-line surveys in March 2015 identify a measurable disruption in the blanket layering. However, the maximum contrast in resistivity shown by the March 2015 surveys in Figures 38 and 39 is much less than the September 2014 surveys previously shown in Figures 36 and 37. 
Figure 37. September 2014 northwestern-most short-line ERT section, adjacent to SB-04 in Figure 35.

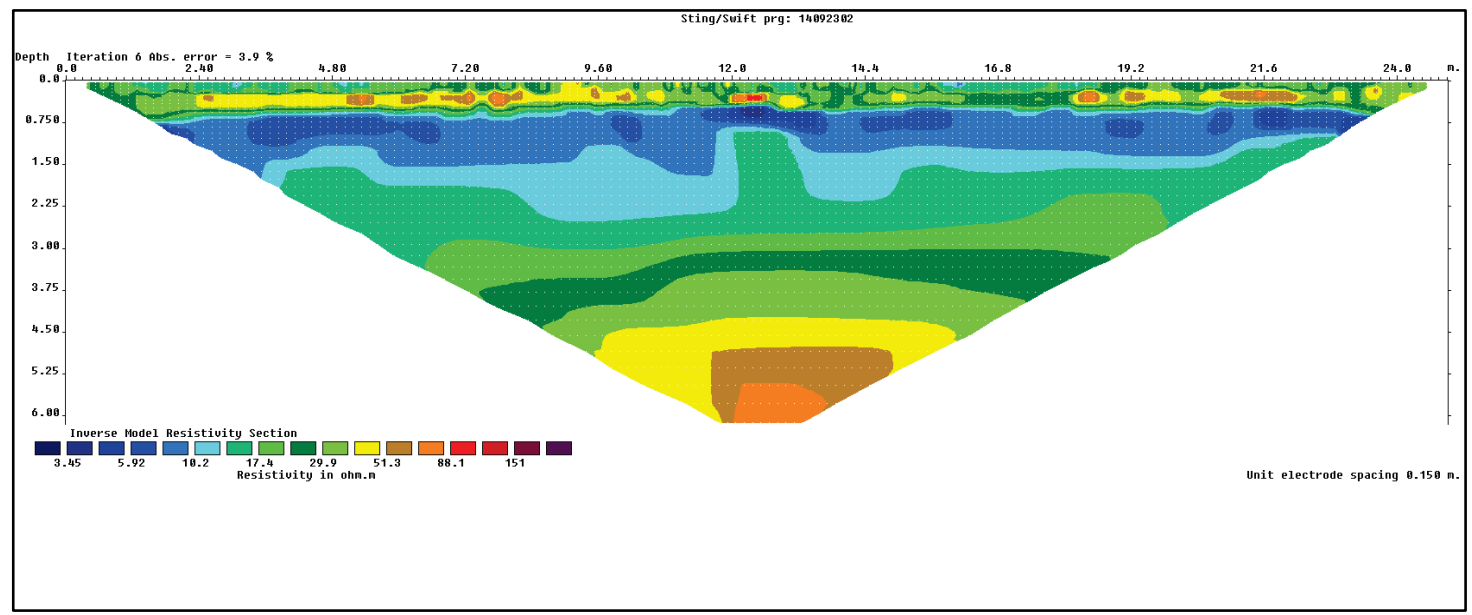

Figure 38. March 2015 short-line resistivity section across SB-04 perpendicular to levee and at same location as Figure 36.

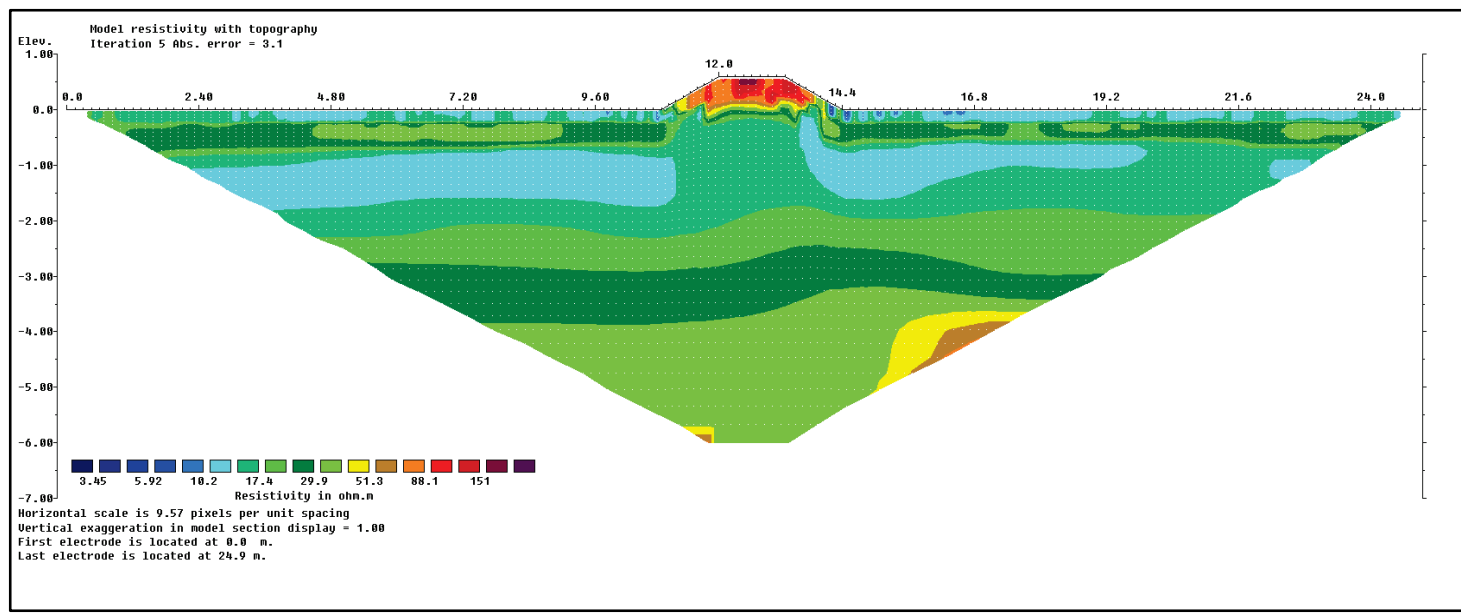

Figure 39. March 2015 short-line resistivity section parallel to levee and across SB-04.

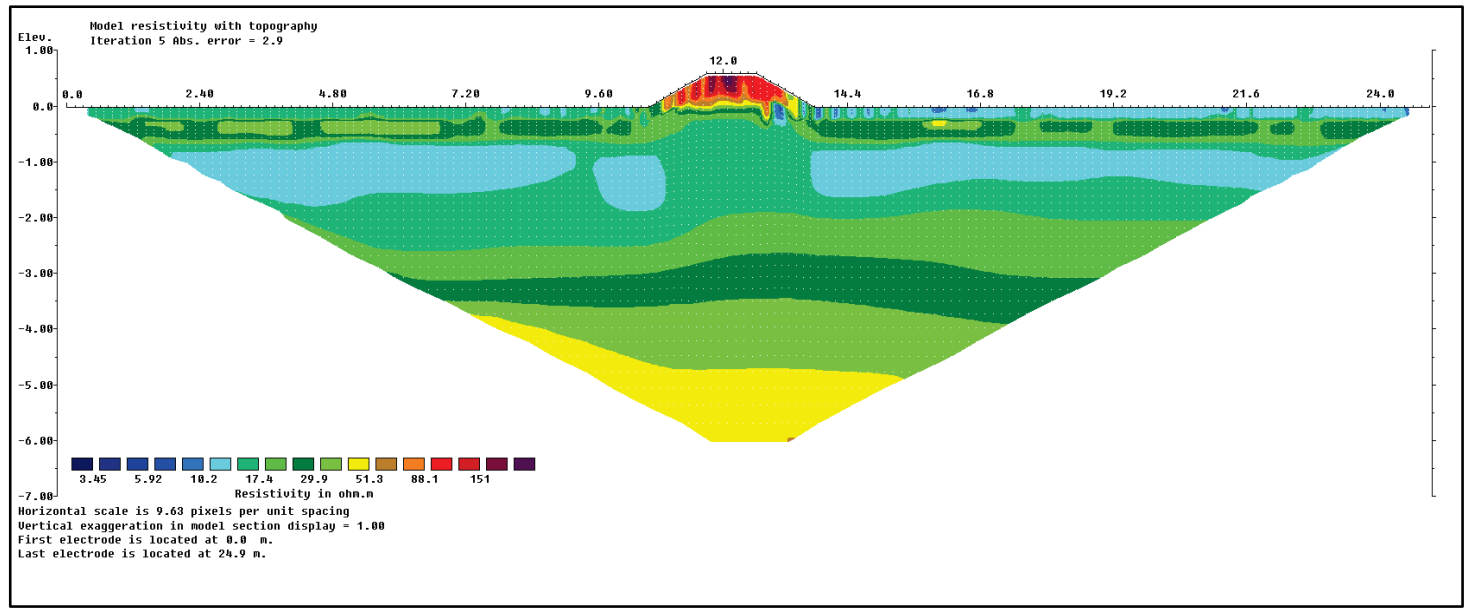


Reasons to account for this resistivity difference between the two surveys involve either a difference in soil moisture in the blanket and/or the degree of aquifer saturation between the fall and spring ERT surveys. Both factors are assessed here. Precipitation data are examined first using the Cape Girardeau, MO, weather station (USWoooo3935). Precipitation for September 2014 was 2.05 in., while precipitation for March 2015 was 8.80 in. (Appendix F). Thus, the fall and spring surveys likely had different soil moisture conditions, which could account for the difference in contrast between the two survey periods.

Groundwater conditions in the alluvial aquifer are assessed by using the Grand Tower river gage (river mile 81.9; $\mathrm{km} \mathrm{138.4)}$ ) and the piezometers from the Preston levee site (river mile $71 ; \mathrm{km} \mathrm{120}$ ). Degree of aquifer (substratum) saturation may be a parameter equally important to soil moisture to account for measured resistivity values, especially where groundwater levels are above the base of the blanket but just below the ground surface. Reference is made to the river stage and piezometer data previously presented in Figure 32. Unfortunately, the record in Figure 32 does not contain measurements for the September 2014 survey period. The Preston site piezometers were installed after the September 2014 surveys were performed. However, a record of river stage data for Grand Tower is available with corresponding piezometer data at Preston that have a record of groundwater levels for similar river stages of interest. Thus, it is possible to estimate the groundwater levels between the two survey periods by using the Grand Tower river gage and piezometer data.

River stages at Grand Tower during the late March to early April 2015 survey period varied from 339.61 to $341.41 \mathrm{ft}$ (103.51 to $104.06 \mathrm{~m}$ ). The corresponding groundwater elevation for the levee toe piezometer for this survey period was at about $335 \mathrm{ft}(102 \mathrm{~m})$, a difference of 4.6 to $6.4 \mathrm{ft}$ ( 1.4 to $2.0 \mathrm{~m}$ ) below river stage. During the late September 2014 survey period, the Grand Tower river gage varied from 344.86 to $347.71 \mathrm{ft}$ (105 to $106 \mathrm{~m}$ ), with a river stage that was approximately $5 \mathrm{ft}(1.5 \mathrm{~m})$ higher than that of the March 2015 time period. The corresponding groundwater level at the levee toe piezometer for this equivalent river stage varies from 332 to $335 \mathrm{ft}$ (101.2 to $102.1 \mathrm{~m}$ ) on the rising limb of the hydrograph (transient seepage conditions) and from 335 to $338 \mathrm{ft}$ (101.2 to 103.0 $\mathrm{m}$ ) on the falling limb of the hydrograph (steady-state seepage conditions) for the plot of river stage versus groundwater levels from data presented in Figure 32. 
The September 2014 survey period probably involved an alluvial aquifer that was not yet fully saturated, with groundwater elevations below $335 \mathrm{ft}$ (101.2 $\mathrm{m}$ ) based on the proxy data presented in Figure 32. The estimated groundwater level would have been at least 5 to $8 \mathrm{ft}$ (1.5 to $2.4 \mathrm{~m}$ ) below the ground surface in the vicinity of SB-04. Thus, it is rather likely the aquifer was at an unsaturated state for the September 2014 surveys. If this viewpoint is correct, then aquifer saturation probably had a negligible effect on the measured resistivity values, and soil moisture was the dominant factor affecting the change in resistivity conditions between the two surveys.

Long-line survey results from the April 2015 that are across SB-04 are presented in Figure 40. This section is at the same location and orientation as the September 2014 long-line section presented earlier in Figure 34 to display properties of resistivity sections and basic geologic layering of alluvial valley sections. The April 2015 ERT section identifies a welldefined $29 \mathrm{ohm}-\mathrm{m}$ resistivity anomaly (denoted by green color) beneath the sand boil, which infers a well-defined seepage pathway through the blanket. Resolution of this feature, in terms of the resistivity values as a function of soil texture, is described in the next chapter examining the CPT data and their results.

Figure 40. April 2015 long-line survey across SB-04 line perpendicular to levee (file 15033102).

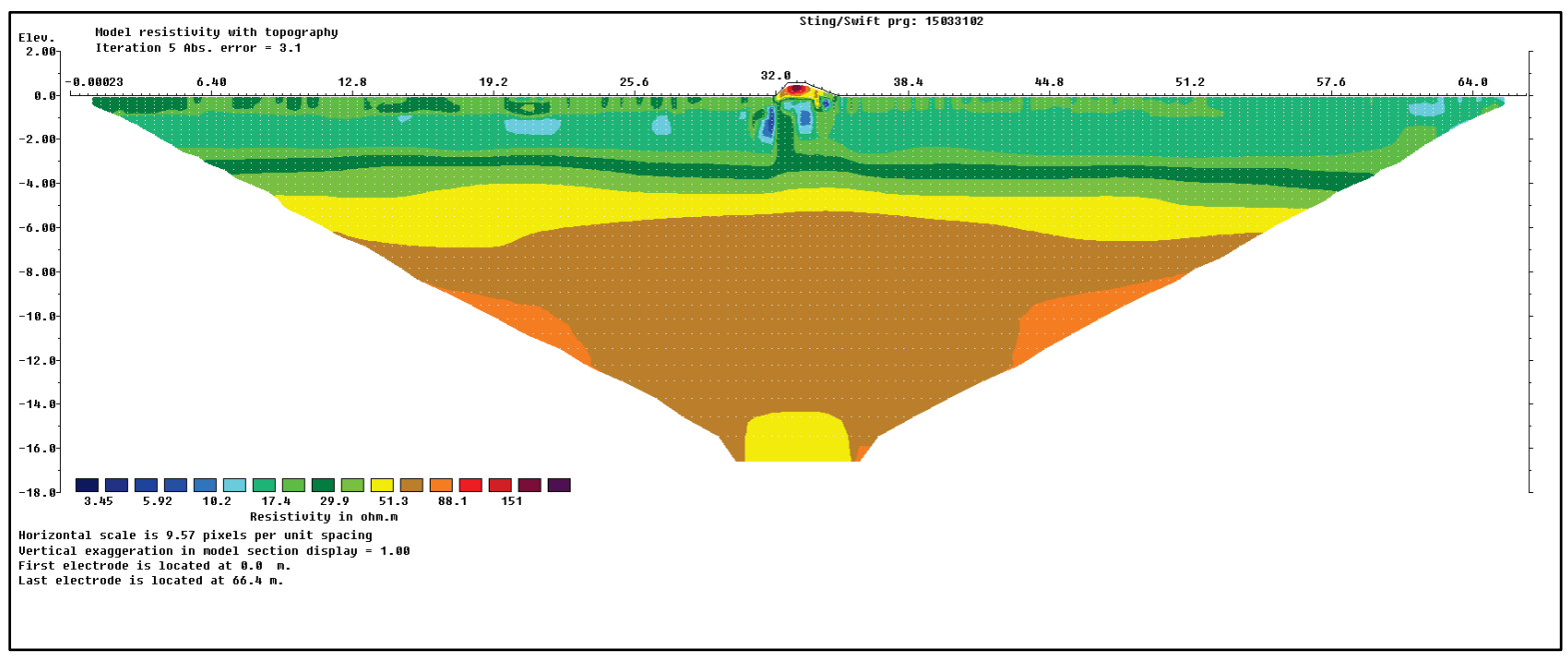

\subsection{Resistivity data from Sand Boil No. 7}

One short-line and two long-line surveys were collected across SB-07 (see Figures 10 to 12 for location and view of sand boil). Individual resistivity sections are presented in Figures 41 to 43 and Appendix E. These 
sections all identify the blanket as being 3 to $4 \mathrm{~m}$ ( 9.8 to $13.2 \mathrm{ft}$ ) thick and underlain by pervious aquifer sands. A resistive layer is present near the surface, which corresponds to transported ejecta from the shallow aquifer. These surveys all identify anomalous discontinuities in the layering that is below the boil, as shown by Figures 41 to 43 . However, the discontinuities in the long-line surveys (Figures 42 and 43) appear more subdued, likely due to the lower resolution caused by the greater electrode spacing. The images obtained from this sand boil are similar to those for SB-O4.

Figure 41. April 2015 short-line survey semi-parallel to levee crossing SB-07.

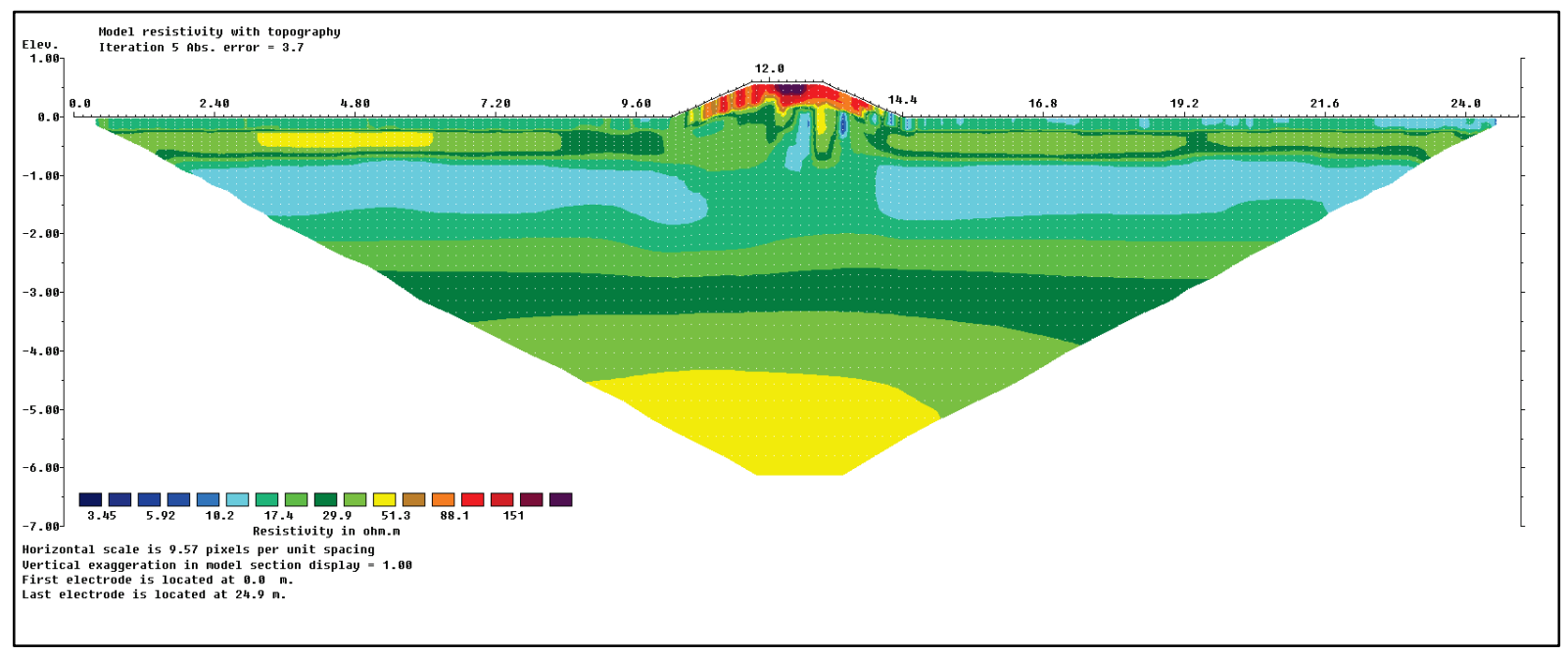

Figure 42. April 2015 long-line survey semi-parallel to levee and crossing SB-07.

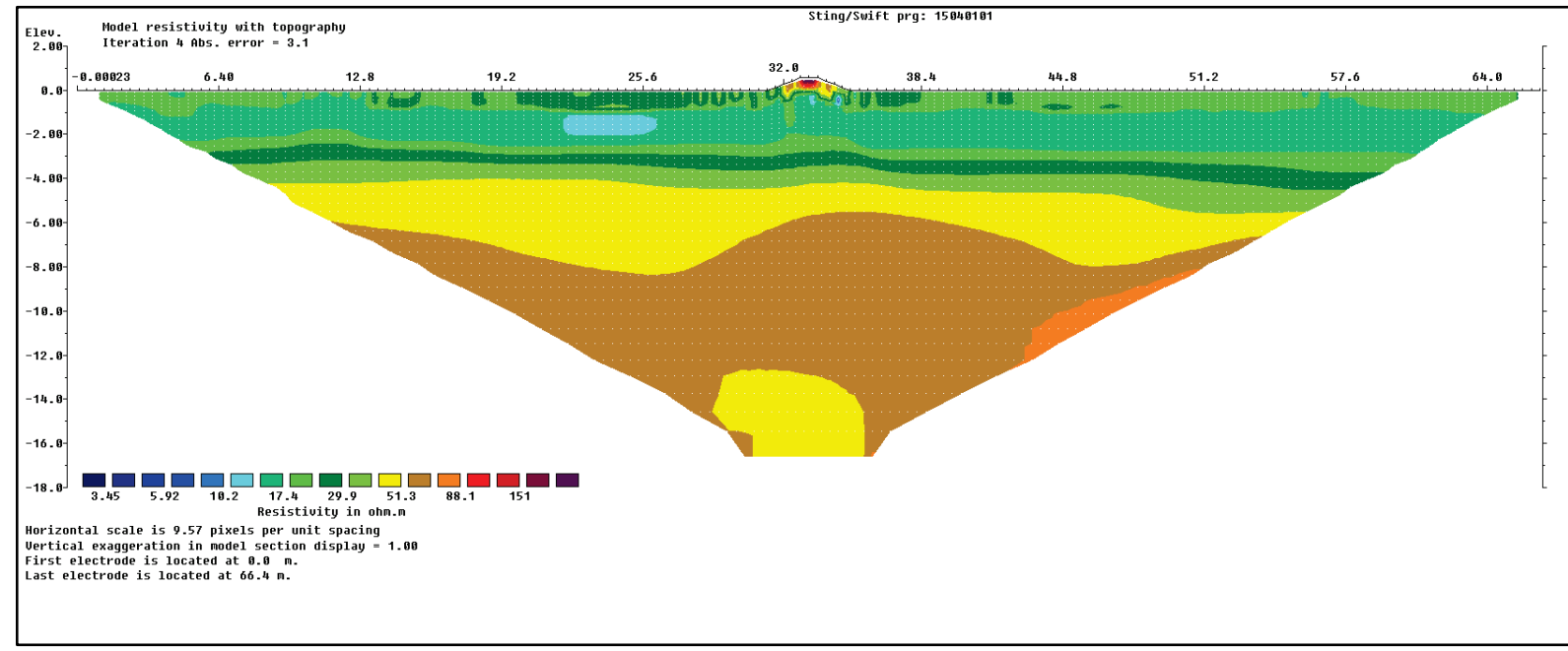


Figure 43. April 2015 long-line survey crossing SB-07, approximately perpendicular to levee, southwest-northwest.

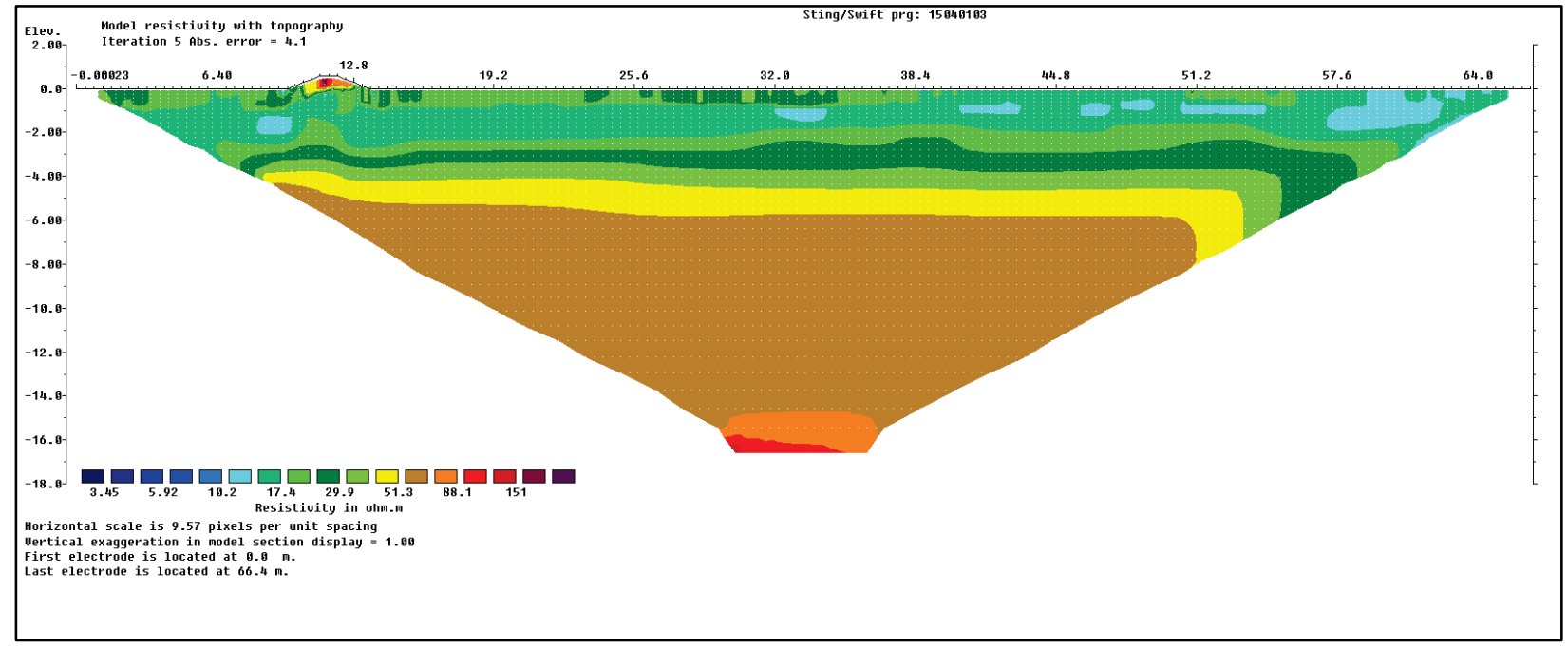

\subsection{Summary}

ERT data collected for this study are all consistent with previous largescale geologic mapping efforts of the alluvial valley in this reach (Woerner et al. 2003). Results of multiple ERT surveys performed in this study in 2014 and 2015 clearly identify a fine-grained top stratum, or blanket, and a lower, pervious alluvial aquifer. The focus for ERT surveys performed in this study was to image the blanket and its interface with the underlying alluvial aquifer and perform time comparisons of selected reaches.

Sand boils imaged by ERT methods for this study identify prominent disruption of the blanket stratigraphy beneath the large sand boils and identify well-defined seepage pathways in the blanket. Trenching through a large sand boil during the field phase of this study was used to identify the presence in the blanket of localized vertical pipes or conduits that are filled with sand. These ejecta have been transported from the underlying alluvial aquifer. Thus, high-resolution ERT imaging of large sand boils at the Preston site was successful and identifies the presence of vertical seepage pathways extending through the blanket and containing measureable differences in resistivity signatures attributed to the movement of pervious soils from the aquifer to the surface. These seepage pathways were corroborated by trenching of a large boil during the field investigation phase of this study. 
The height of the sand cones at the Preston site is governed by tailwater conditions, and the sand cones attain the height of the maximum water level elevation during impounding of underseepage flow in low-lying areas during flood-related events. The presence of sheet sands in the immediate vicinity of the larger sand boils at the Preston site is further direct evidence for movement of sand boil ejecta under submerged conditions from the presence of multiple sand boils in this area.

Repeat resistivity surveys in terms of location and orientation were performed across selected sand boils during Fall 2014 and Spring 2015. Lower resistivity values were obtained during the 2015 survey period from identical locations previously surveyed in 2014. These differences are likely attributed to higher monthly rainfall totals in 2015 and corresponding increase in soil moisture conditions in the shallow blanket. Thus, higher resistivity values obtained during Fall 2014 surveys were likely caused by the presence of coarse-textured soils present in the shallow blanket. The sharper contrast in resistivity values was likely aided by the lower moisture conditions present at this time in the blanket soils.

An interpretation of multiple, closely spaced ERT surveys measured a similar sand boil signature and identified a local defect and/or hydraulic fracture in the blanket at this location. The presence of sheet sands, sand cones at the surface, and anomalous high contrast resistivity signatures below the sand boils are the products of sand moving to the surface from the underlying aquifer. This condition occurs because of large hydraulic gradients developed at the land side toe of the levee in the alluvial aquifer and a blanket unable to contain the artesian pressures that develop.

Corroboration of resistivity data in terms of soil texture previously described was verified by CPTs and selected soil sampling of different stratigraphic horizons. These data are presented in more detail in the next chapter of this report. 


\section{Cone Penetrometer Tests (CPT)}

\subsection{Introduction}

CPT data were collected during the period from 28 April 2015 to 2 May 2015. Twenty-four CPTs were pushed at the Preston site (Figures 23 and 44). CPT soundings ranged from less than $10 \mathrm{ft}(3 \mathrm{~m})$ up to $70 \mathrm{ft}(21.3 \mathrm{~m})$ in depth. CPT logs are presented in Appendix B. The soil type identified on each $\log$ is based on empirical relationships developed by Robertson et al. (1986) for cone-tip resistance and sleeve friction. Locations of sand boils, CPTs, CPT cross sections, and resistivity survey lines important to this discussion are shown in Figure 44.

\subsection{Blanket thickness and top stratum elevation}

Contour maps were compiled from the CPT data to identify blanket thickness and elevation to the top of the substratum. The blanket thickness in the vicinity of the large diameter sand boil varies from 9 to $13 \mathrm{ft}(2.7$ to 4.0 m), as shown by Figure 45. Closer to the levee, the blanket is overlain by fill and forms the narrow berm. Maximum thickness ranges from 16 to $20 \mathrm{ft}$ ( 4.9 to $6.1 \mathrm{~m}$ ) (corresponds to the green-to-brown color interval). Blanket thickness generally decreases with increasing distance from the levee toe. Additionally, there is a noticeable west-to-east trend in thickness that is highlighted by the maroon color interval.

An elevation map for the top of the substratum deposits (alluvial aquifer) using CPT data is presented in Figure 46. For comparison purposes, ground surface elevations in the vicinity of the sand boil area are typically at $340 \mathrm{ft}(103.6 \mathrm{~m}) \mathrm{msl}$ (Figure 8). The contour map shows two elevation highs separated by a broad west-east trending low at 326 to $327 \mathrm{ft}$ (99.4 to $99.7 \mathrm{~m}$ ). This elevation low corresponds to a zone containing fine-grained blanket deposits and is directly responsible for the concentration of sand boil activity north of this low area. The low probably represents a blocked exit condition illustrated earlier in Figure 8 (USACE 1956a). Thus, sand boil activity at the Preston site occurs where the substratum deposits are above elevation $328 \mathrm{ft}(100 \mathrm{~m}) \mathrm{msl}$, and there is an abrupt change in hydraulic conductivity in the shallow surface due to this feature. This blocked exit condition locally is likely due to a swale or chute formed by past Mississippi River migration. 
Figure 44. Location of sand boils, CPTs, and selected resistivity sections.

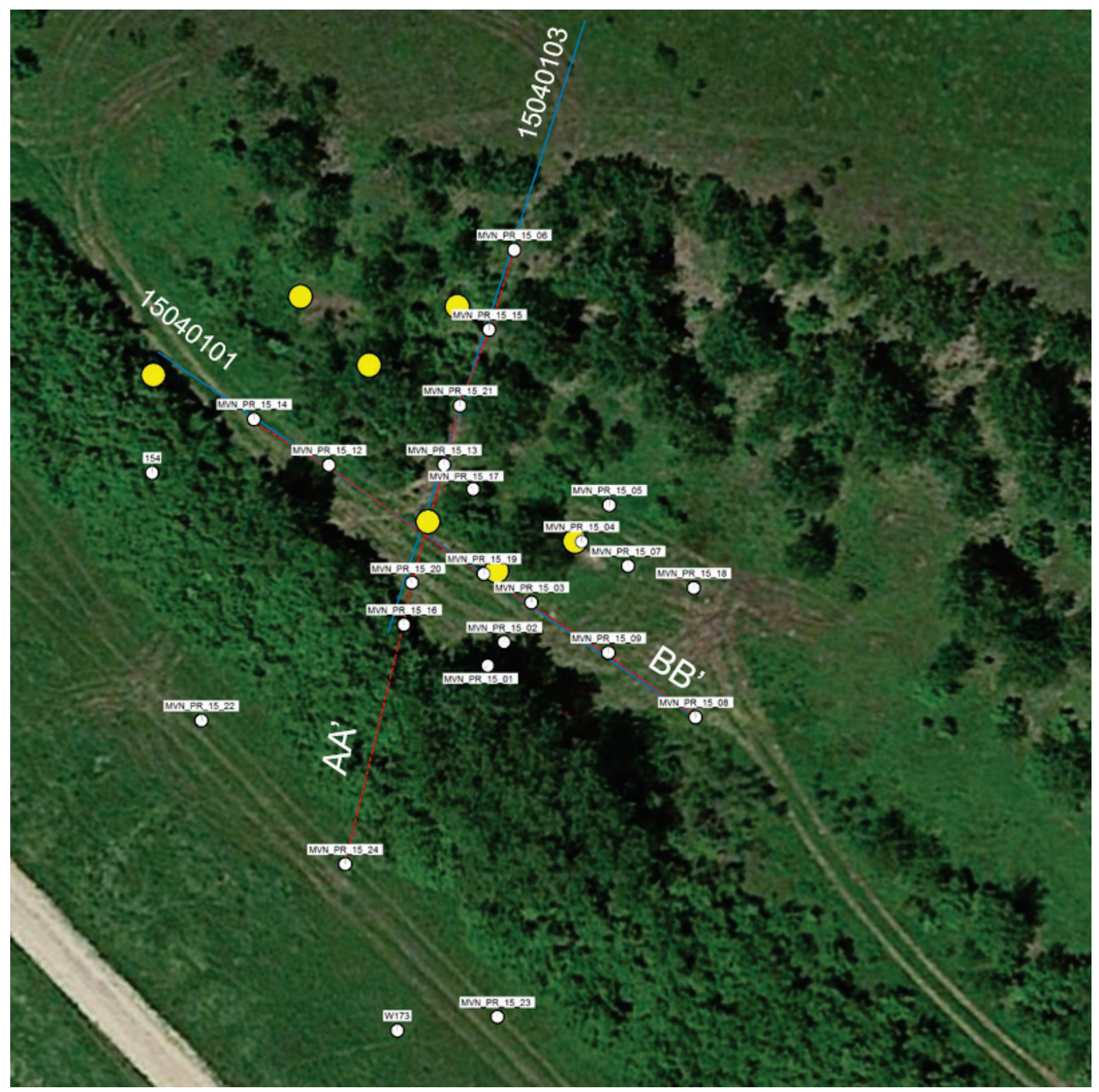

\subsection{CPT cross sections}

CPT data were next compiled into two cross sections that extend perpendicular and parallel with the levee at the Preston site (Figures 47 and 48). These sections identify the typical alluvial stratigraphic sequence created by a meandering river channel, containing a fine-grained top stratum and pervious substratum. This sequence is a fining-upward texture in terms of USCS soil types and associated grain size. This sequence normally ranges from coarse sands and gravels at the base of the former river channel to silts and clays at the surface. Two fundamentally 
different depositional processes create this unique deposit. Lateral accretion of sand and gravel occurs on the inside bendway of the channel, forming the substratum; vertical accretion during overbank flooding forms the top stratum. These processes form the fluvial landform characteristic of chutes and bars, or point bar deposits (Figure 6).

Figure 45. Blanket thickness contour map in feet. Sand boil locations in yellow.

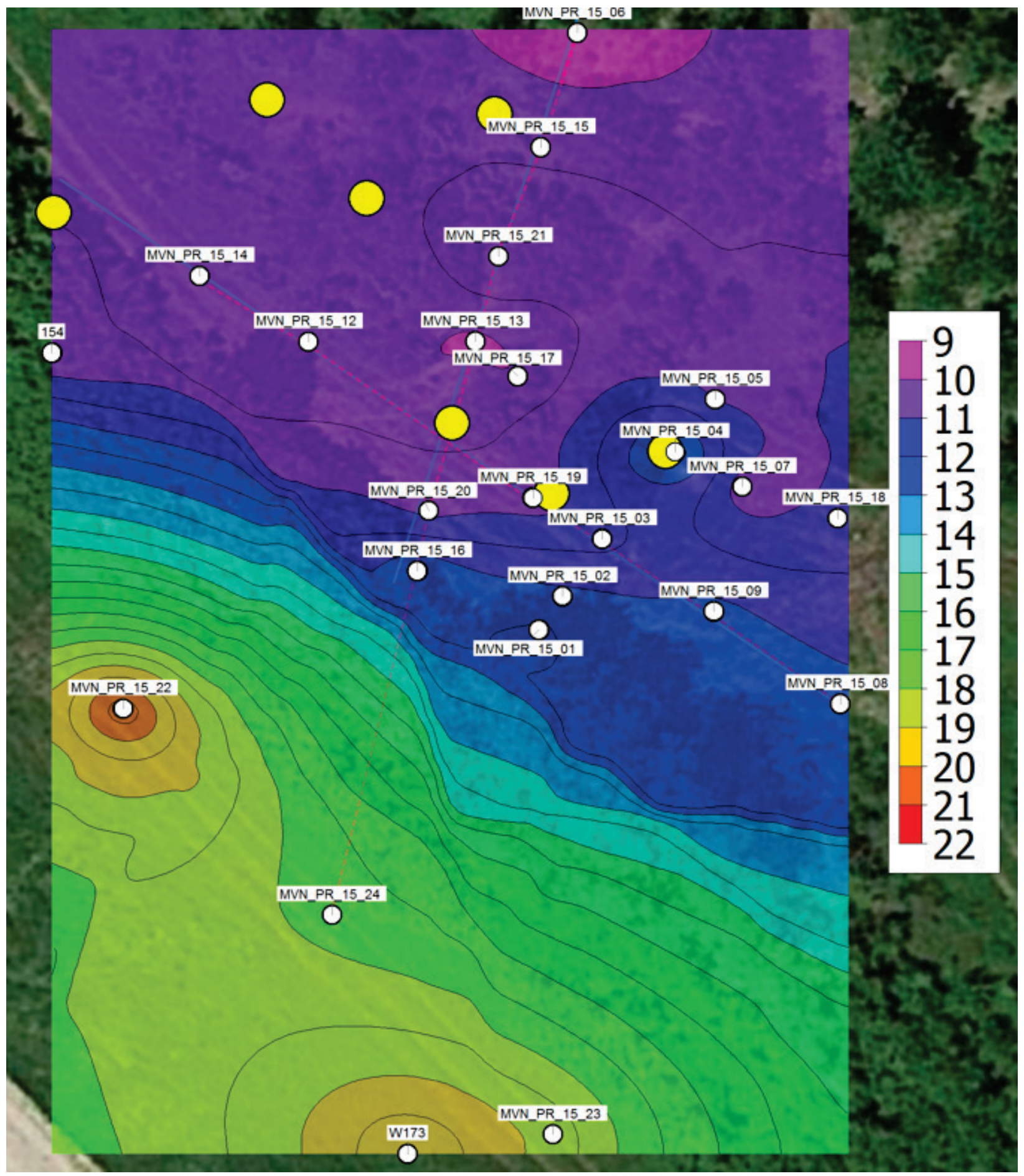


Figure 46. Elevation to the top of substratum sands ( $\mathrm{ft} \mathrm{msl}$ ).

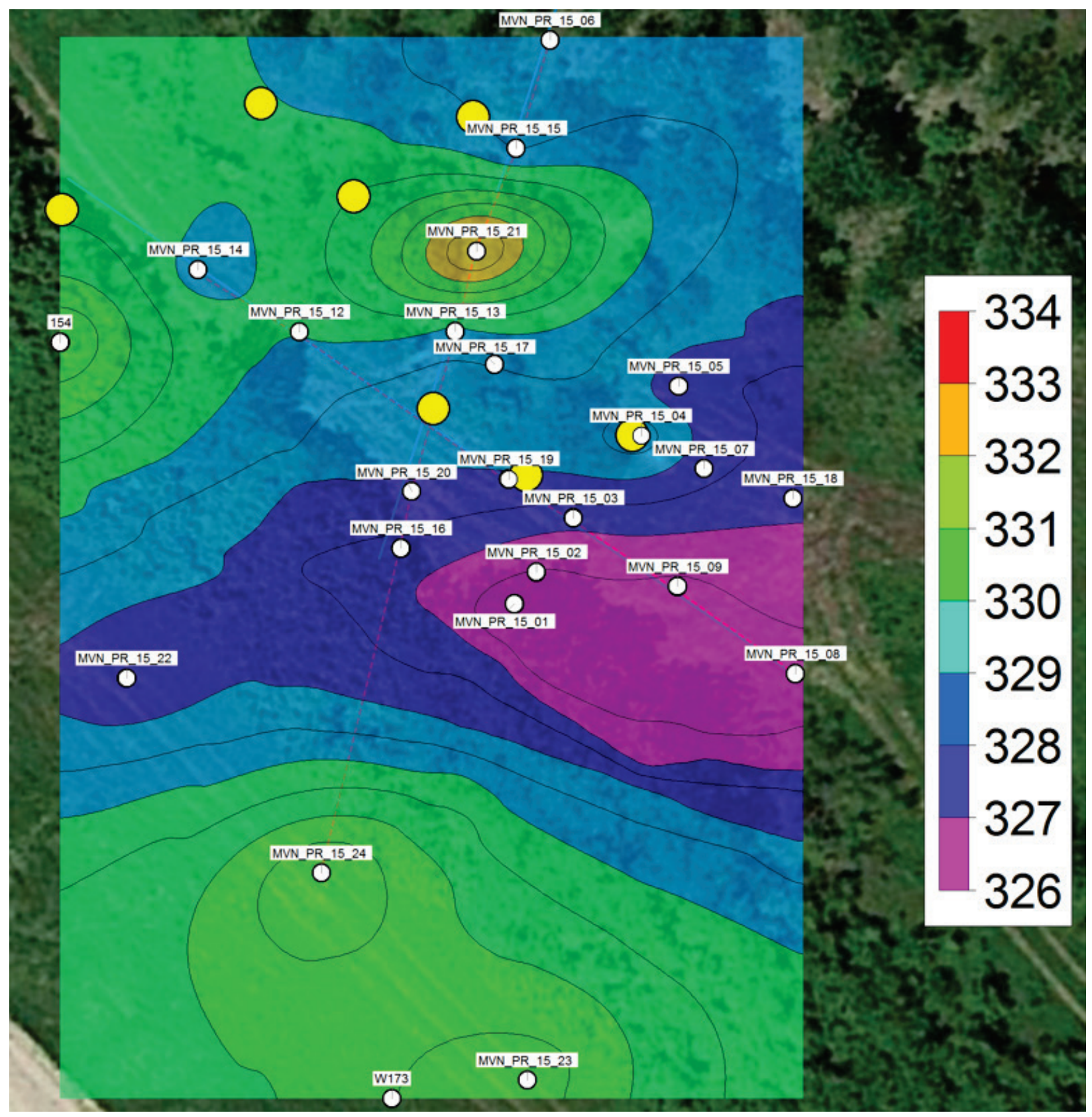


Figure 47. CPT section A-A'.

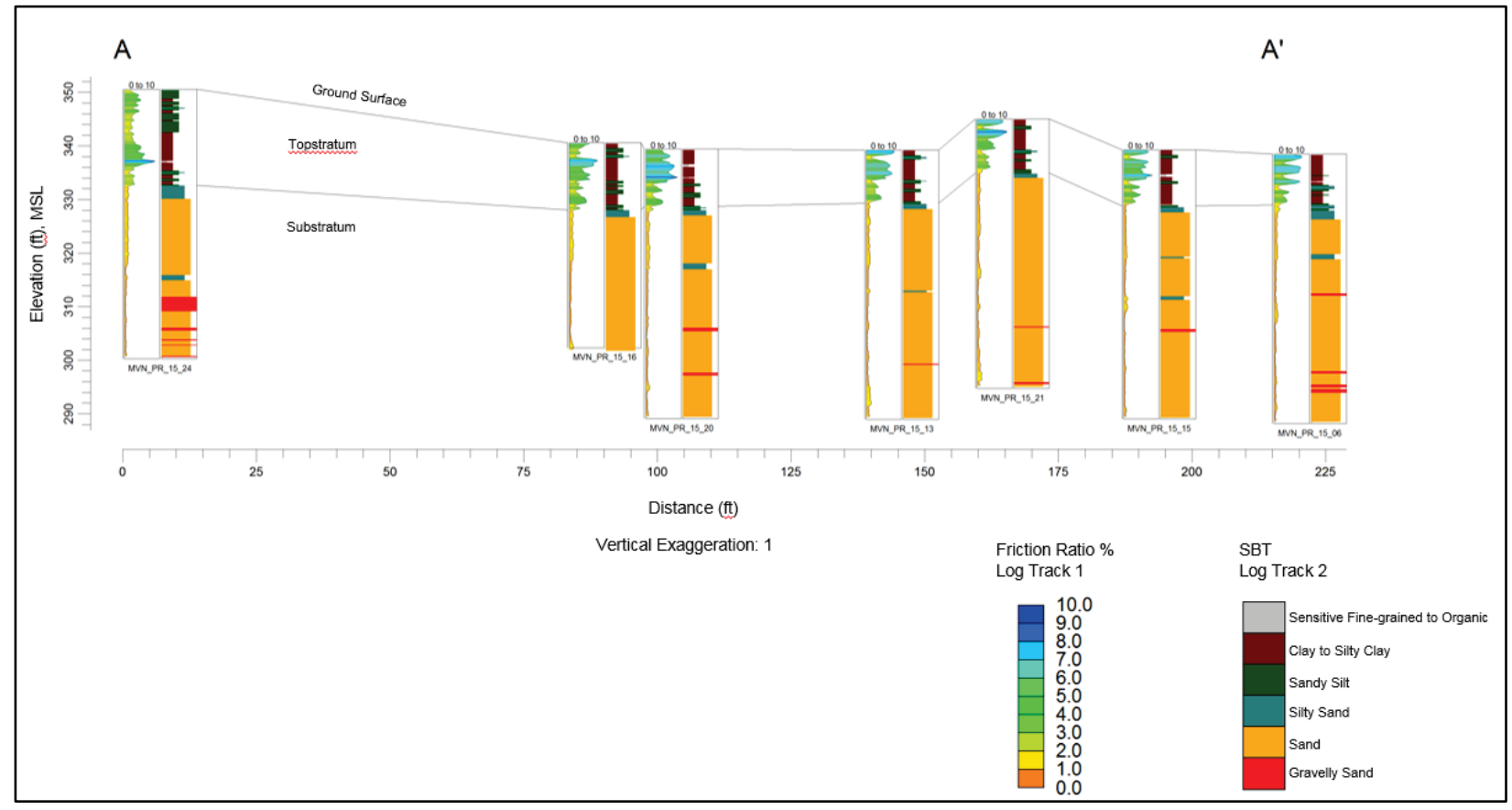

Figure 48. CPT section B-B'.

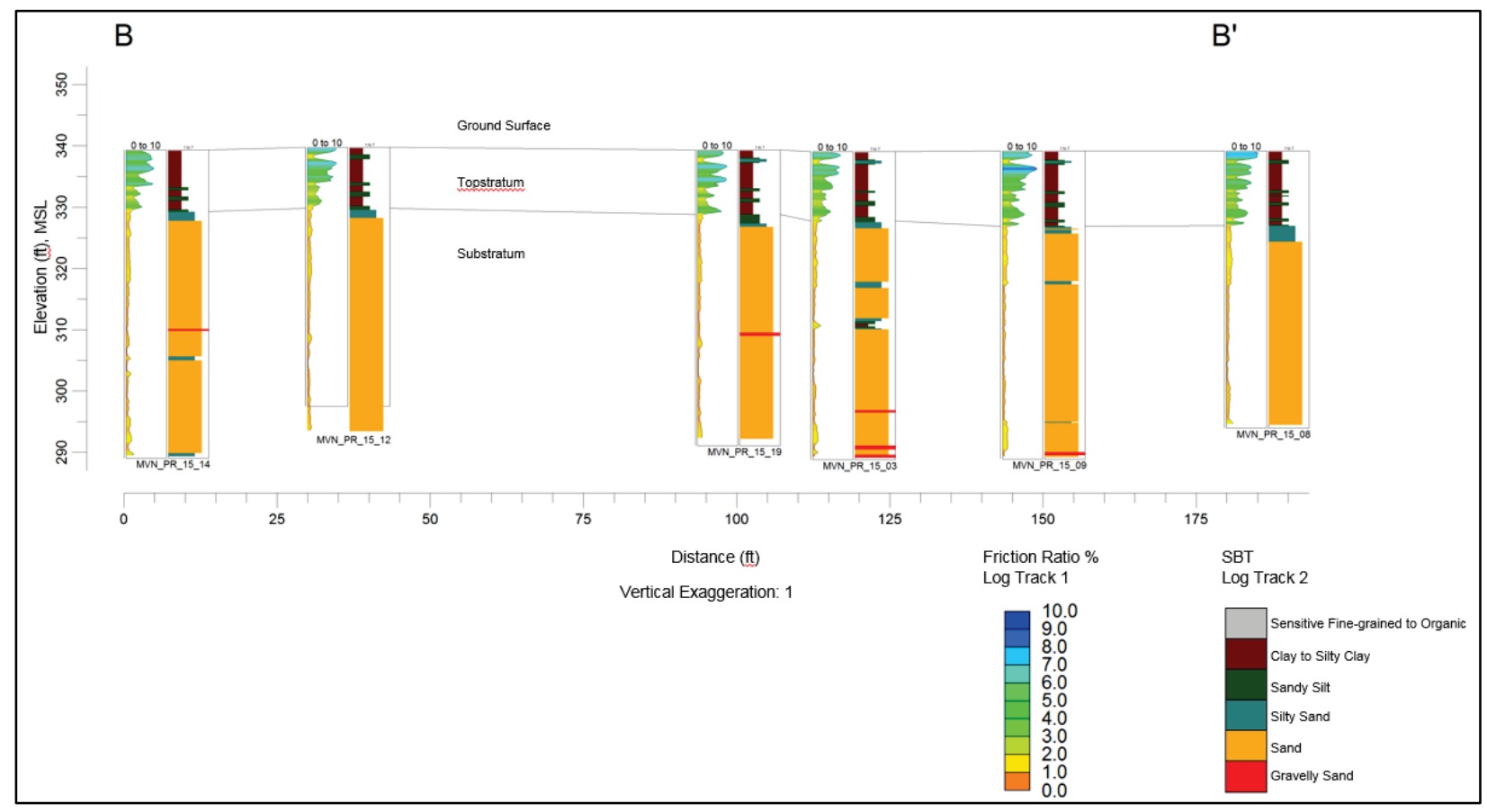




\subsection{Friction ratio cross sections}

Cross sections of CPT data in terms of percent friction ratio are presented as Figures 49 and 50. A model of the skin friction, divided by the tip resistance, provides an interpolation of the stratigraphy in terms of their ratios (soil type), with low ratio values corresponding to sandy textures or desiccated clays and high ratios representative of fine-grained soils corresponding to clays. This CPT model of the subsurface at the Preston site clearly identifies the top stratum-substratum boundary and shows the presence of coarse soil textures present beneath SB-07 in cross section A$\mathrm{A}^{\prime}$ (Figure 49). The section that extends parallel to the levee contains a well-defined sandy layer near the surface, corresponding to the layer deposited from sand boil activity, as previously described in Figure 50.

\subsection{Comparison of CPT and resistivity data}

A simple comparison of resistivity and CPT data is made in Figures 51 and 52. The merger of these two datasets provides corroboration and verification of the signatures obtained from the ERT surveys.

The inversion process and resistivity sections match closely with the CPT data in terms of the separation of the top stratum and substratum units. However, less certain are specific soil types (i.e., silt versus fine sand) in terms of their resistivity values, especially at the boundary between the top stratum and substratum units. The resistivity interval from 22 to $26 \mathrm{ohm}-\mathrm{m}$ generally corresponds to this transition point for the moisture conditions occurring at the time these surveys were performed.

Note the color table that has been used in the resistivity discussion has been changed to favor a larger range of values at the lower end of the scale range, where these soils are more conductive or less resistive.

A correlation of resistivity (or conductivity) values for common rocks and soils is presented as Figure 53. The range of values of interest to this study involves floodplain soils at the Preston site. Values identified in Figure 53 are general ranges for background understanding of the contrast in values commonly associated with different rocks and soils. Values at Preston are specific to conditions at this site. 
Figure 49. Plot of friction ratio for cross section A-A'.

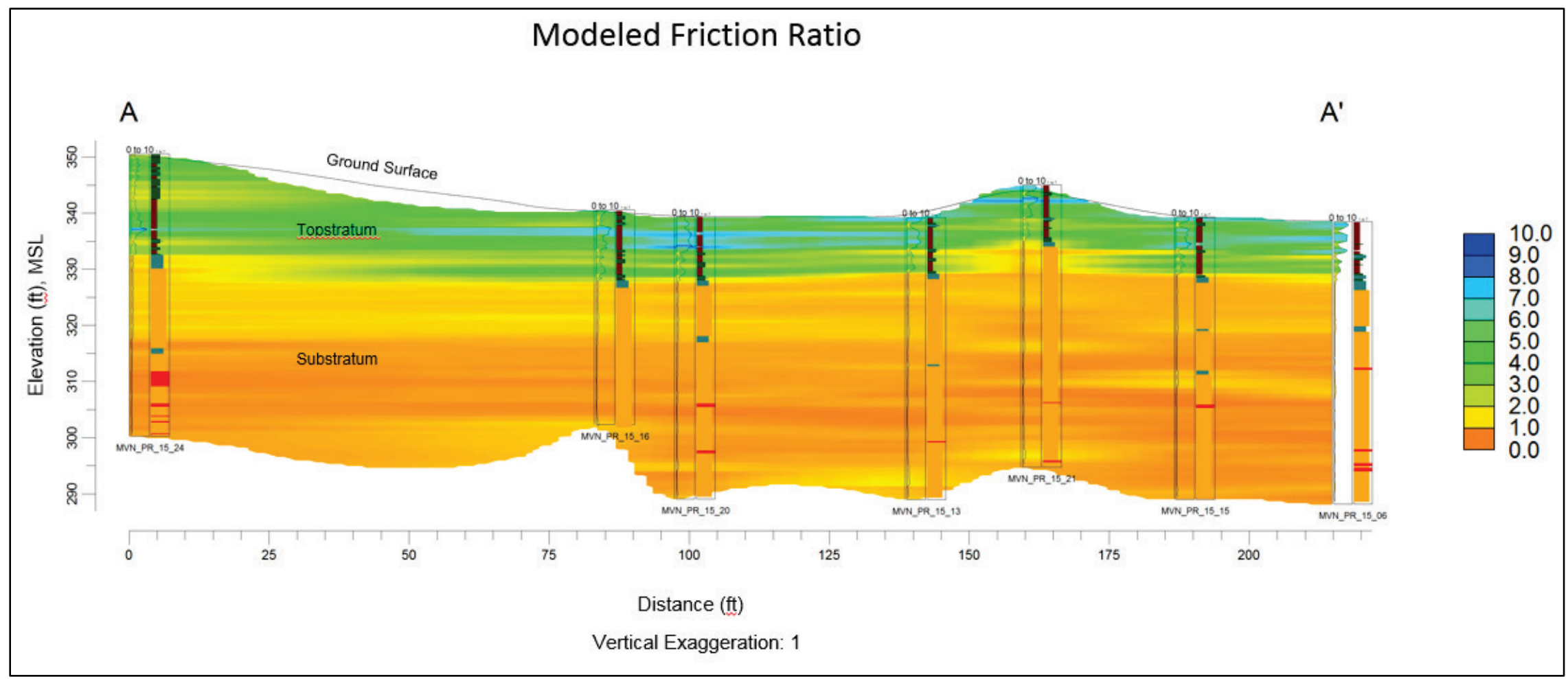


Figure 50. Plot of friction ratio for cross section B-B'.

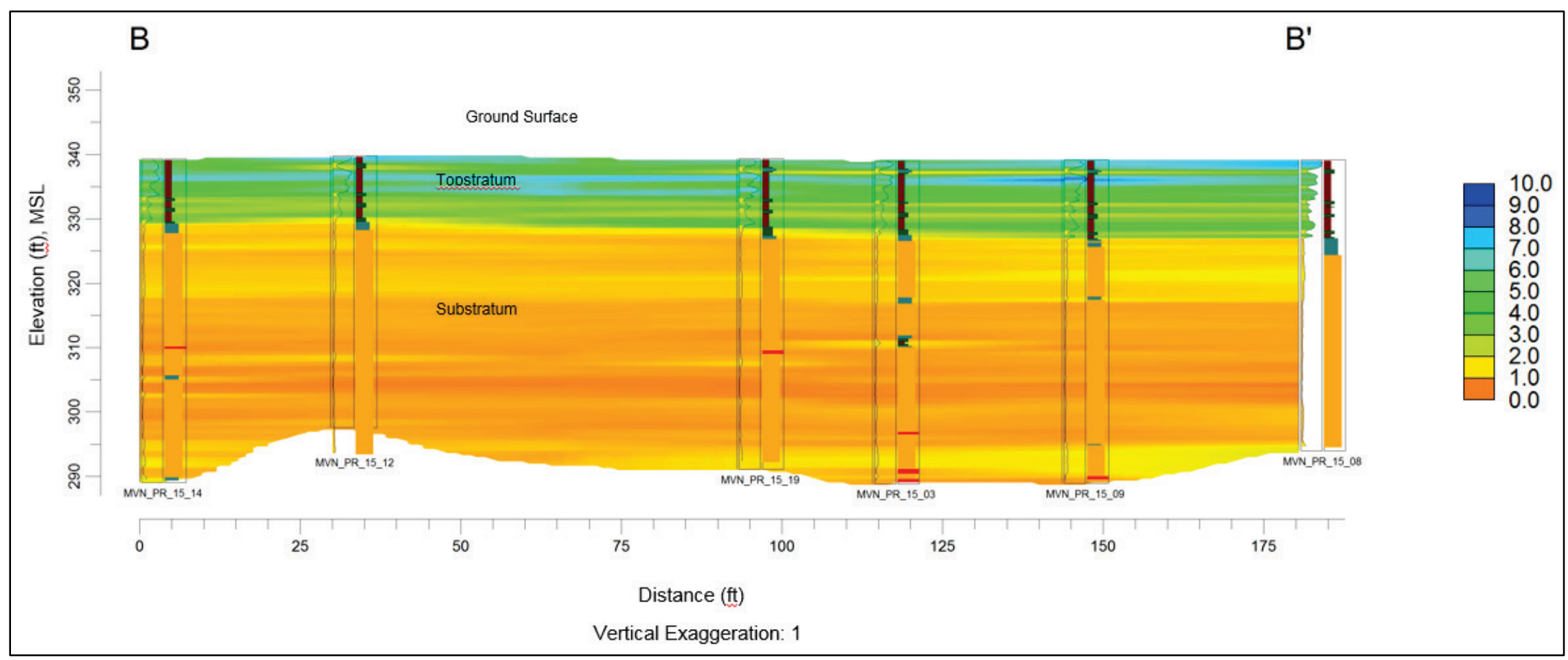


Figure 51. Comparison of CPT and resistivity data for cross section A-A'.

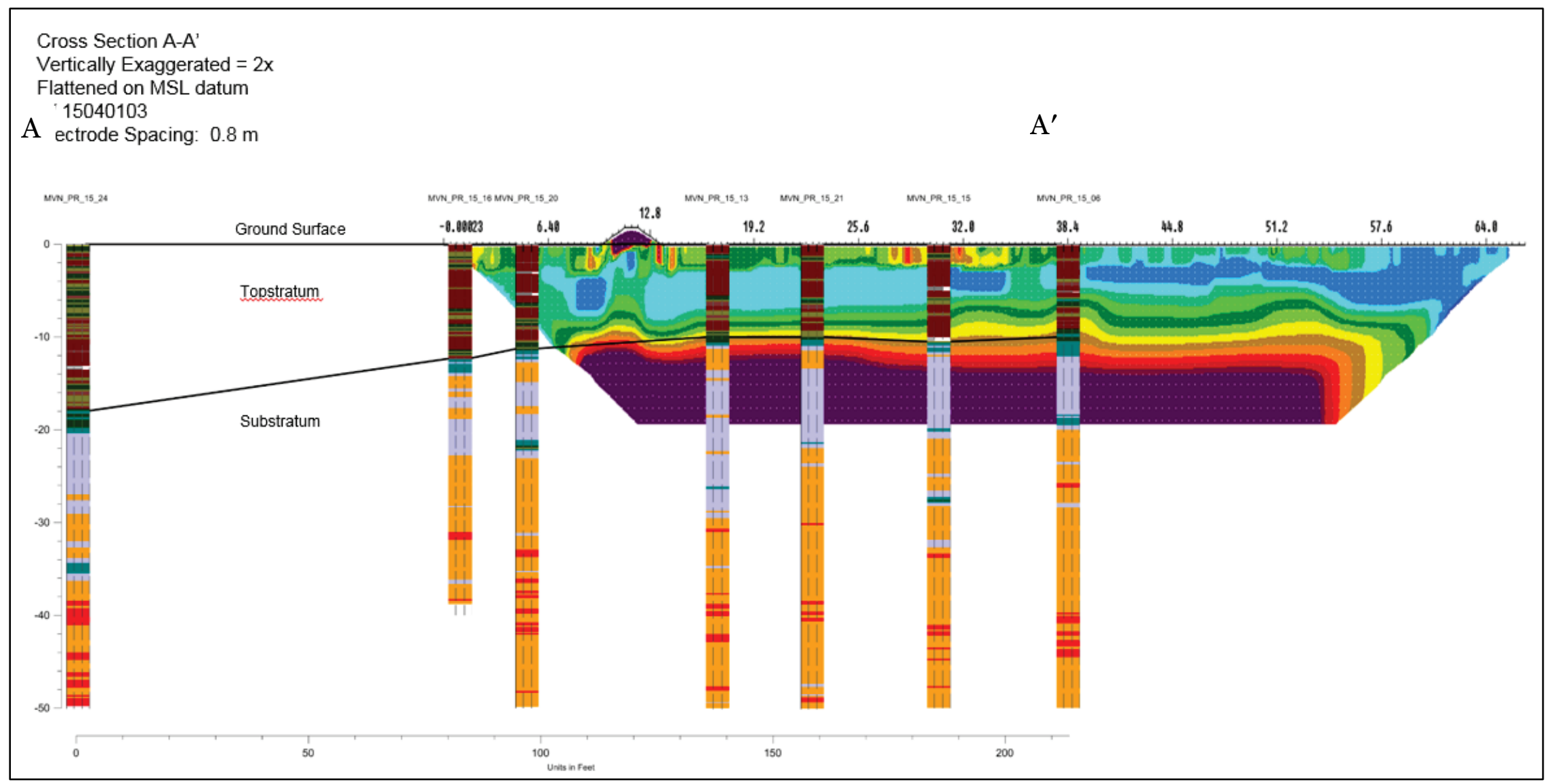


Figure 52. Comparison of CPT and resistivity data for cross section B-B'.

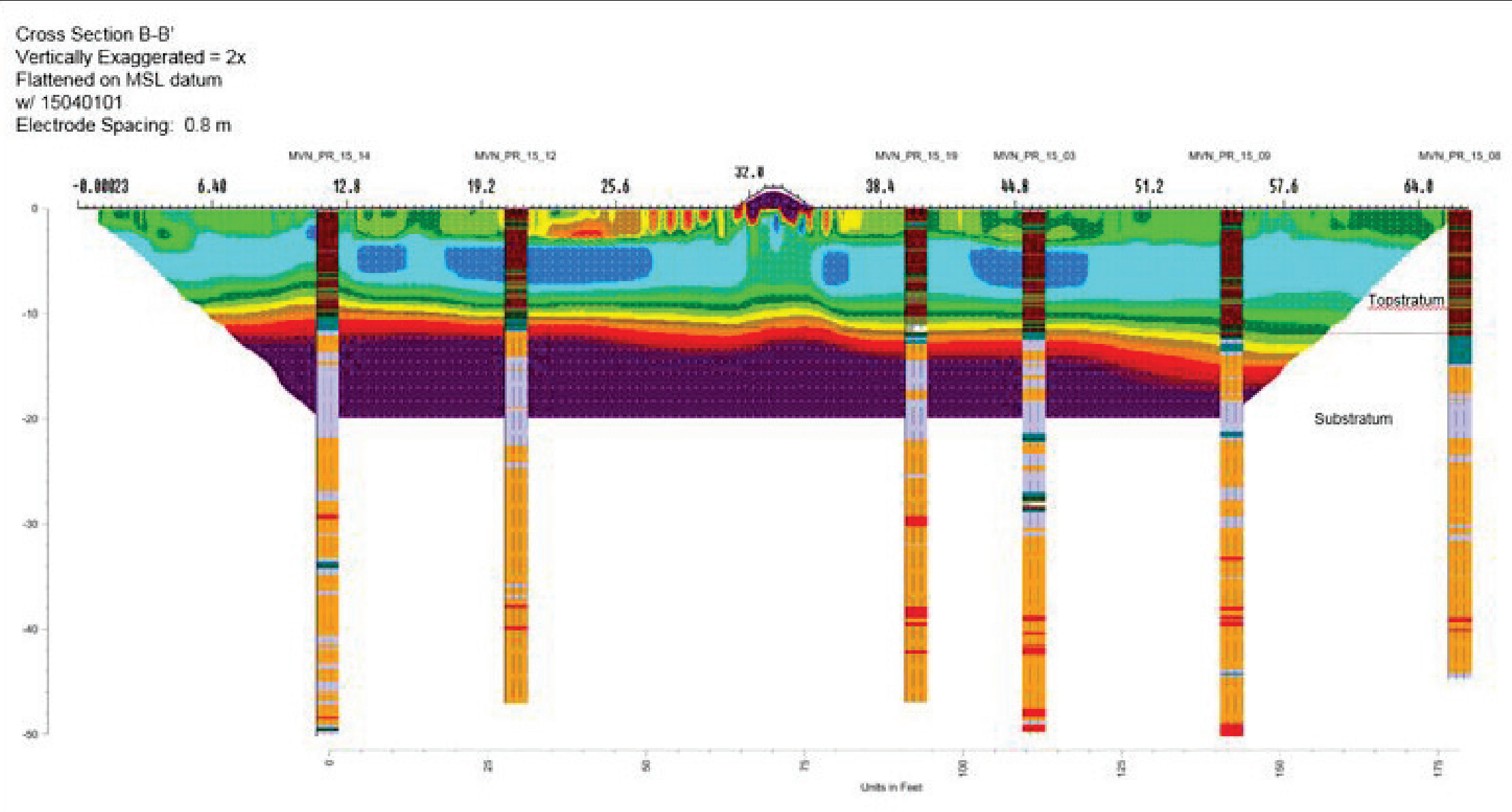


Figure 53. Resistivity values as a function of earth materials (Palacky 1988).

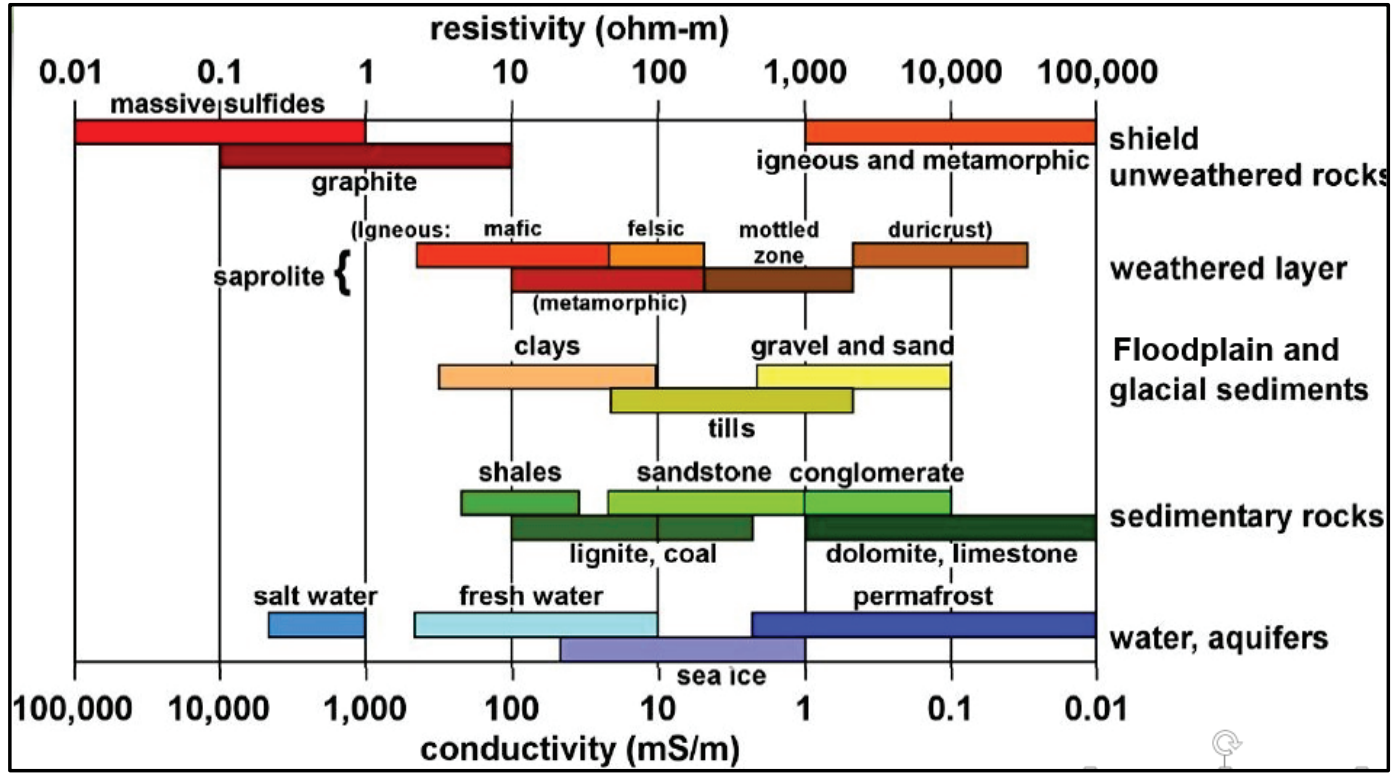

\subsection{Laboratory classification of sand boil ejecta and blanket}

Selected soil sampling was conducted as part of the field reconnaissance and CPT data collection phases of this study. The purpose for the sampling was to determine the properties and source of the ejecta in the soil column. Sampling results of ejecta from selected sand boils are presented in Table 2. Sampling was performed from both the cone and the blanket at most of the larger boils sampled.

Table 2. Sand boil ejecta soil properties.

\begin{tabular}{|l|l|l|l|l|l|l|l|l|l|l|l|l|}
\hline Feature & Boil No. & No. & \% Gravel & \% Sand & \% Fines & \% Silt & \% Clay & \multicolumn{2}{l|}{ Classification } & LL* & PL* & PI* \\
\hline Cone & No. 1 & PR-1A & 0.0 & 25.4 & 74.6 & 69.9 & 4.7 & ML & Silt with Sand & NV & NP & NP \\
\hline Cone & No. 1 & PR-1A-ECJ-1 & 0.0 & 20.1 & 79.9 & 69.6 & 10.3 & ML & Silt with Sand & NV & NP & NP \\
\hline Cone & No. 1 & PR-1B & 0.0 & 10.3 & 89.7 & 85.8 & 3.9 & ML & Silt & NV & NP & NP \\
\hline Blanket & No.1 & PR-1C & 0.0 & 5.4 & 94.6 & 51.1 & 43.5 & CH & Clay & 52 & 18 & 34 \\
\hline Cone & No. 2 & PR-2A & 0.0 & 37.1 & 62.9 & 58.7 & 4.2 & ML & Sandy Silt & NV & NP & NP \\
\hline Blanket & No. 2 & PR-2B & 0.0 & 5.6 & 94.4 & 47.3 & 47.1 & CH & Clay & 55 & 20 & 35 \\
\hline Cone & No. 4 & PR-4A & 0.0 & 47.3 & 52.7 & 48.5 & 4.2 & ML & Sandy Silt & NV & NP & NP \\
\hline Blanket & No. 4 & PR-4B & 0.0 & 3.3 & 96.7 & 50.6 & 46.1 & CH & Clay & 59 & 20 & 39 \\
\hline Cone & No. 7 & PR-7 & 0.0 & 80.2 & 19.8 & 15.9 & 3.9 & SM & Silty Sand & NV & NP & NP \\
\hline Cone & No. 8 & PR-8 & 0.0 & 64.2 & 35.8 & 30.7 & 5.1 & SM & Silty Sand & NV & NP & NP \\
\hline
\end{tabular}

* $\mathrm{LL}=$ liquid limit; $\mathrm{PL}=$ plastic limit, $\mathrm{PI}=$ plasticity index. 
Classification of the blanket samples identified a $\mathrm{CH}$ soil. The ejecta varied in terms of grain size between sandy silt (ML) to silty sand (SM). The percentage of sand and fines was determined for each sample tested. Fines were further classified by their silt and clay faction for the samples tested. Atterberg limits were not run on the coarse-grained ejecta samples.

Laboratory test results from samples within the blanket are presented in Table 3. Selected soil sampling in the blanket was performed with the CPT at anomalous intervals and at the transition between the blanket and the substratum. Samples obtained from the blanket were primarily clay $(\mathrm{CH})$ and those near the transition corresponded to silt (ML). Grain-size curves from soil samples taken within the blanket are presented in Appendix D. Atterberg limits were not performed.

Table 3. Laboratory soil class of blanket samples.

\begin{tabular}{|l|l|l|l|l|}
\hline Boring & Sample & Depth & USCS & Remarks \\
\hline MVN-PR-15-03 & 1 & $9-10.5$ & $\mathrm{CH}$ & Soft zone, Sand boil \\
\hline MVN-PR-15-03 & 2 & $9-10.5$ & $\mathrm{ML}$ & Bottom of blanket, Sand boil \\
\hline MVN-PR-15-04 & 1 & $8-9.5$ & $\mathrm{CH}$ & SB-04, CPT, Sand boil \\
\hline MVN-PR-15-04 & 2 & $8-9.5$ & $\mathrm{CH}$ & SB-04, CPT, Sand boil \\
\hline MVN-PR-15-04 & 3 & $8-9.5$ & $\mathrm{CH}$ & SB-04, CPT, Sand boil \\
\hline MVN-PR-15-04 & 4 & $8-9.5$ & $\mathrm{CH}$ & SB-04, CPT, Sand boil \\
\hline MVN-PR-15-04 & 1 & $12-13.5$ & $\mathrm{ML}$ & SB-04 Soft zone, CPT, Sand boil \\
\hline MVN-PR-15-19 & 1 & $9--10.5$ & $\mathrm{CH}$ & Blanket \\
\hline MVN-PR-15-19 & 2 & $9--10.5$ & $\mathrm{CH}$ & Blanket \\
\hline MVN-PR-15-19 & 3 & $9--10.5$ & $\mathrm{CH}$ & Blanket \\
\hline MVN-PR-15-19 & 4 & $9--10.5$ & $\mathrm{CH}$ & Blanket \\
\hline MVN-PR-15-19 & 1 & $11-12.5$ & $\mathrm{ML}$ & Soft zone, Blanket \\
\hline MVN-PR-15-24 & 1 & $12.5-14$ & $\mathrm{CH}$ & Soft zone, Blanket \\
\hline MVN-PR-15-24 & 2 & $12.5-14$ & $\mathrm{CH}$ & Blanket \\
\hline MVN-PR-15-24 & 3 & $12.5-14$ & $\mathrm{CH}$ & Blanket \\
\hline MVN-PR-15-24 & 1 & $16-17.5$ & $\mathrm{ML}$ & Bottom of blanket, Blanket \\
\hline MVN-PR-15-24 & 2 & $16-17.5$ & $\mathrm{CH}$ & \\
\hline MVN-PR-15-SB-01 & $2 \mathrm{~B}, 4 \mathrm{~A}$ & Surface & $\mathrm{CH}$ & Surface, upper boil area \\
\hline MVN-PR-15-SB-01 & $1 \mathrm{~A}$ & Surface & $\mathrm{CH}$ & Sand from neck \\
\hline MVN-PR-15-SB-01 & $1 \mathrm{~B}$ & Surface & $\mathrm{ML}$ & Sand from neck, Silt w/sand \\
\hline
\end{tabular}




\subsection{Source of the ejecta, transport mechanism, and sand cone development}

Physical characterization of the blanket and the source of the ejecta within the stratigraphic column were based on detailed definition of the site stratigraphy using resistivity, CPT methods, and sampling and trenching of a sand cone. Selected soil samples were obtained to verify soil types associated with the ejecta (Table 2) and to sample specific horizons in the blanket and near the upper aquifer (Table 3). Additionally, selected soil sampling was performed to classify anomalous signatures observed. With this sampling strategy in mind, a discussion about the source of the ejecta is presented herein for interpretation of the resistivity results and the physical evidence observed at the site.

Resistivity imaging of the blanket and trenching has confirmed the presence of seepage pathways in the blanket from either hydraulic fracturing, existing fissures and tension cracks, animal burrows, or other types of blanket defects (e.g., soil desiccation, man-made disturbances, or bioturbation). The natural progression that is envisioned is that these pathways develop and enlarge from repeat flood events over time. Thus, these features eventually form eroded channels or pipes because of the concentration of seepage flow at these defects.

As shown by ejecta samples in Table 2 and Figures 26 and 27, these pathways are sediment-filled and contain soil textures that are believed to be primarily representative of the upper aquifer. Ejecta observed from the field data are transported to the surface, and/or temporarily deposited and stored in these preferred pathways until the next flood event mobilizes the ejecta and the pathway is again activated. This mobilized sediment derives its provenance either from a specific stratigraphic horizon(s) in the upper aquifer or from the winnowing and entraining of particles at a specific grain size range from the aquifer matrix. The distribution of the grain size that is transported and deposited (Table 2) is primarily dependent on the hydraulic gradient and seepage velocity occurring in the pathway. The source for the sediment is likely a combination of both of these methods based on the distribution of the sand cones, the presence of sheet sands, and their resistivity response identified near surface. The upper aquifer corresponds to the point bar environment, which is a fining-upward soil texture. Thus, aquifer deposits reflect their stratigraphic origin, sediment transport characteristics, and soil texture distribution. 
Short-survey ERT lines in Figures 36, 37, and 41 identify sheet sands that are sandwiched between high conductivity (low resistivity) layers. As previously described, the sand cones and sheet sands likely develop under submerged conditions as the tailwater forms by concentration of underseepage flow in low-lying areas. Thus, sand movement is facilitated by submerged conditions and particle transport down the sand cone because of the seepage velocity in the cone and aqueous particle transport under the influence of gravity. This building process has an active phase with maximum sediment transport occurring during boththe rising and falling limbs of the flood hydrograph when the boil is most active. The height of the sand cone is likely determined by the elevation of the standing water.

The active phase of cone development is then followed by an inactive phase, where the very fine-grained sediment in the tailwater begins to settle out of suspension in the standing water that has developed in the low-lying areas. Thus, fine-grained particles eroded by seepage forces in the pathways in the blanket, or winnowed from the fines that are present in the aquifer sands, settle from suspension. This two-stage depositional model produces a composite cone that can display a bimodal grain-size distribution. The fine-grained layer overlying the sheet sands in the vicinity of the boil area is additional evidence for the inactive or suspension phase of sediment deposition.

\subsection{Summary}

Selected soil sampling was performed to validate the CPT soil classification at anomalous stratigraphic intervals and to determine the soil types associated with signatures obtained from resistivity surveys.

An important boundary for levee engineering is the top stratum and substratum interface. This boundary corresponds to the change from finegrained to coarse-grained soil textures. Geomorphically, this textural boundary represents the change in deposition from primarily vertical to lateral accretion, or deposition that occurs by overbank flooding by suspended sediment outside of and adjacent to the river channel, versus deposition within the channel from suspended bedload and formation of sandbars by channel migration.

The top stratum boundary was easily recognized in the resistivity sections obtained from the Preston site. In these results the resistivity interval from 22 to $26 \mathrm{ohm}-\mathrm{m}$ generally corresponds to the boundary between the top 
stratum and the substratum. Resistivity values at Preston that are less than this range are normally fine-grained and are part of the top stratum. Values that are more than 22 to $26 \mathrm{ohm}-\mathrm{m}$ typically comprise the substratum and correspond to coarse-grained soils. Of course, these specific resistivity values and ranges for the top stratum and substratum will vary with time as moisture content changes but, even with changing moisture content, the coarser substratum is expected to remain at higher resistivity values than the finer-grained top stratum.

An important parameter that impacts the signature response of resistivity surveys is the moisture content of the soils at the time the survey was performed. One of the primary modes of current flow in soils involves the movement of electrons through ionic solutions trapped between the pore spaces in the soil matrix. Thus, the degree of soil moisture is an important component contributing to the measured resistivity response at the time the survey was performed. This phenomenon was readily observed at the Preston site by time lapse surveys of SB-04. Comparison of resistivity results between the September 2014 and March 2015 survey periods in Figures 36 and 38 yielded similar results, as well as sharp differences because of soil moisture differences. The September 2014 surveys were performed with drier soil conditions than the March 2015 surveys, and the presence of higher resistivities (potentially substratum sands) near the surface. Thus, the degree of soil saturation, as well as electrode spacing, can have a primary influence on target resolution. Maximum contrast of the blanket by ERT methods favors drier soil conditions.

A measurable disruption to the blanket stratigraphy beneath the boil is identified from resistivity surveys across selected large sand boils, which extend through the fine-grained blanket. Electrode spacing used in this study involved both fine and coarse resolution surveys. Both types of surveys identified localized changes to the blanket beneath the large boil areas. Short-line surveys with $0.3-\mathrm{m}$ (1-ft) electrode spacing were better able to resolve stratigraphic features beneath boils. Because of the longer electrode spacing, the resolution of the deeper blanket features becomes less pronounced with depth.

Extensive sheet sands were observed in the proximity of the large sand boils that were present. These sand sheets were deposited under submerged conditions. Concentration of seepage occurs in low-lying areas during flooding with the source of sand derived from the large boils 
present. This sand layer, in turn, is overlain by a layer of clay. This twolayer sequence indicates a two-stage depositional model. The active phase corresponds to sand cone formation by transport of foundation sands to the surface under high river stages and surcharged aquifer conditions. This phase is next followed by fine-grained deposition of suspended sediment under falling river conditions and subsequent depressurization of the alluvial aquifer. Bimodal deposition of soil texture was observed and occurs with this sand boil model at the Preston site.

Sand boil formation was associated with an abrupt change in the hydraulic conductivity properties of the blanket. A blocked exit condition occurs locally in the flow path, whereby a buried west-to-east trending chute or swale has caused pressure buildup in the alluvial aquifer behind this buried feature. Concentration of sand boil activity in this area is further enhanced by any local defects present in the blanket due to soil desiccation, burrowing animals, tree roots, or other natural and man-made discontinuities. A contributing factor to the sand boil activity at this site is the orientation of the levee to the buried chute or swale (Figure 9). 


\section{Seepage, Sand Boil Activity, and Control}

\subsection{Alton-to-Gale levee system}

The Alton-to-Gale levee system was built to provide flood protection to a 50-year flood frequency, and the levees were subsequently raised during the 1940s and 1950s (USACE 1956b). The Preston levee site is part of the Preston Drainage and Levee District and part of the Alton-to-Gale levee system. The St. Louis District and the USACE Waterways Experiment Station (WES) studied foundation conditions along the levee system to identify critical reaches and to design and construct appropriate seepage control measures (USACE 1956b). These measures involved more than 240 miles of levee, 2,100 relief wells, and 14 landside seepage berms in 16 levee districts. However, local opposition occurred in some districts to the relief wells discharging onto valuable agricultural lands. The absence of planned relief wells at the Preston Levee site was due to lack of local sponsor cooperation (USACE 1976).

\subsection{Exit gradient}

Seepage control policy for USACE levees has historically been based on the concept of exit gradient $\left(i_{o}\right)$ to determine whether counter measures (e.g., berms, relief wells, or cutoff walls) are needed at the land side toe of the levee (USACE 1947, 1956a, 1956b, 2000; Wolff 2002). The exit gradient is derived from definition of the foundation geology and the hydraulic properties at the location being evaluated (Figure 54). The exit gradient corresponds to the ratio of $h_{o} / z$, where $h_{o}$ is the excess hydraulic head above the ground surface that would be measured at a piezometer at the location of interest, and $z$ is the blanket or top stratum thickness at that location (USACE 1956a, 1956b). Where piezometer data are unavailable, analytical solutions were developed by USACE (1956a, 1956b) to calculate the exit gradient for various geologic cases observed in the Mississippi River Valley. 
Figure 54. Primary variables for exit gradient calculations.

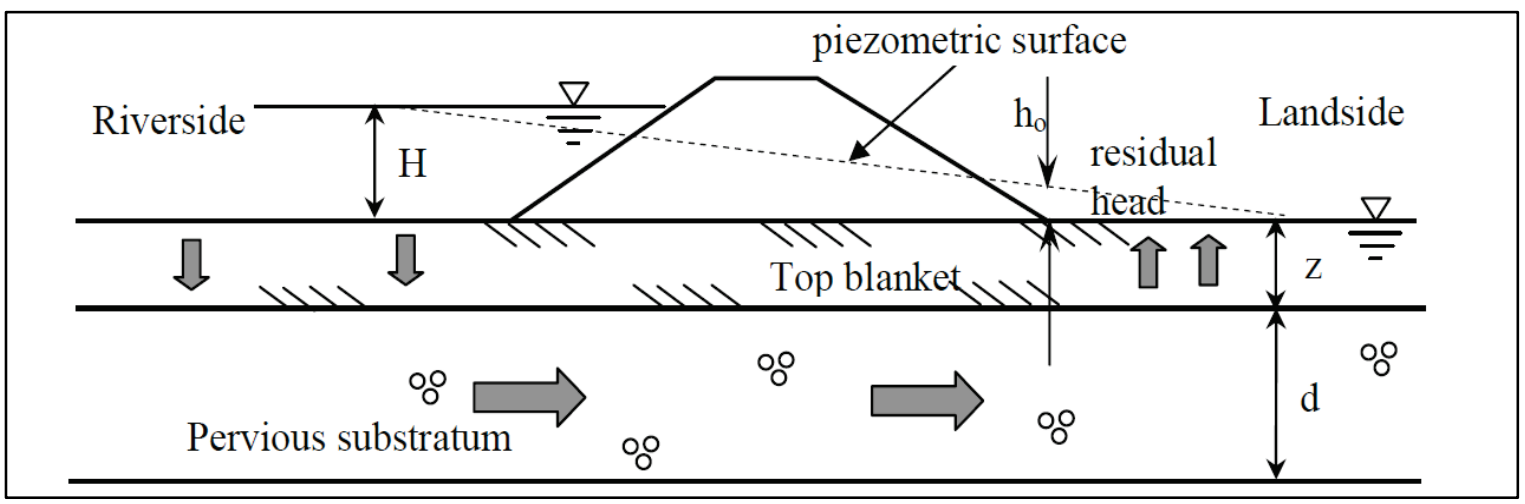

\subsection{Exit gradient and critical gradient related to sand boil activity}

Empirical studies of seepage and sand boil activity were performed by USACE at study sites in both the Middle and Lower Mississippi Valley during the 1940 s and 1950 s to fully understand the geologic conditions responsible for seepage and sand boil occurrence (USACE 1941, 1956a, 1956b). These field studies provided empirical relationships to relate the exit gradient at the various sites studied to severity of seepage and occurrence of sand boil activity (Figure 55). Sand boil activity was observed to occur at exit gradients above 0.5 , and dangerous boils were encountered at exit gradients as low as 0.7 (USACE 1947).

In addition to the hydraulic gradient and the blanket thickness, material properties of the blanket itself have a direct bearing on seepage and sand boil potential. The gradient required to cause heaving and possible fracturing of the top stratum is defined as the critical gradient and corresponds to the ratio of the submerged unit weight of the soil comprising the top stratum and the unit weight of water (Turnbull and Mansur 1961).

For cohesive soils, the critical gradient is at 0.8 for soils with unit weights of between 112 to $115 \mathrm{lb} / \mathrm{ft}^{3}$ (1.79 to $1.84 \mathrm{~kg} / \mathrm{lb}$ ), which is typical of topstratum deposits within the alluvial valley. The buoyant weight for silts and sands is often attained at this critical gradient, resulting in a quick condition and upward flotation of the silt and sand grains to the surface as a sand boil (USACE 1941). Thus, local defects in the uniformity of the top stratum and blocked exit conditions previously described can adversely contribute to sand movement from the foundation to the land surface and result in much lower gradients for sand transport to occur. As noted by Figure 55, sand boil activity has been observed at gradients as low as 0.2. 
Figure 55. Relationship between exit gradient and severity of seepage and occurrence of sand boils (USACE 1956b).

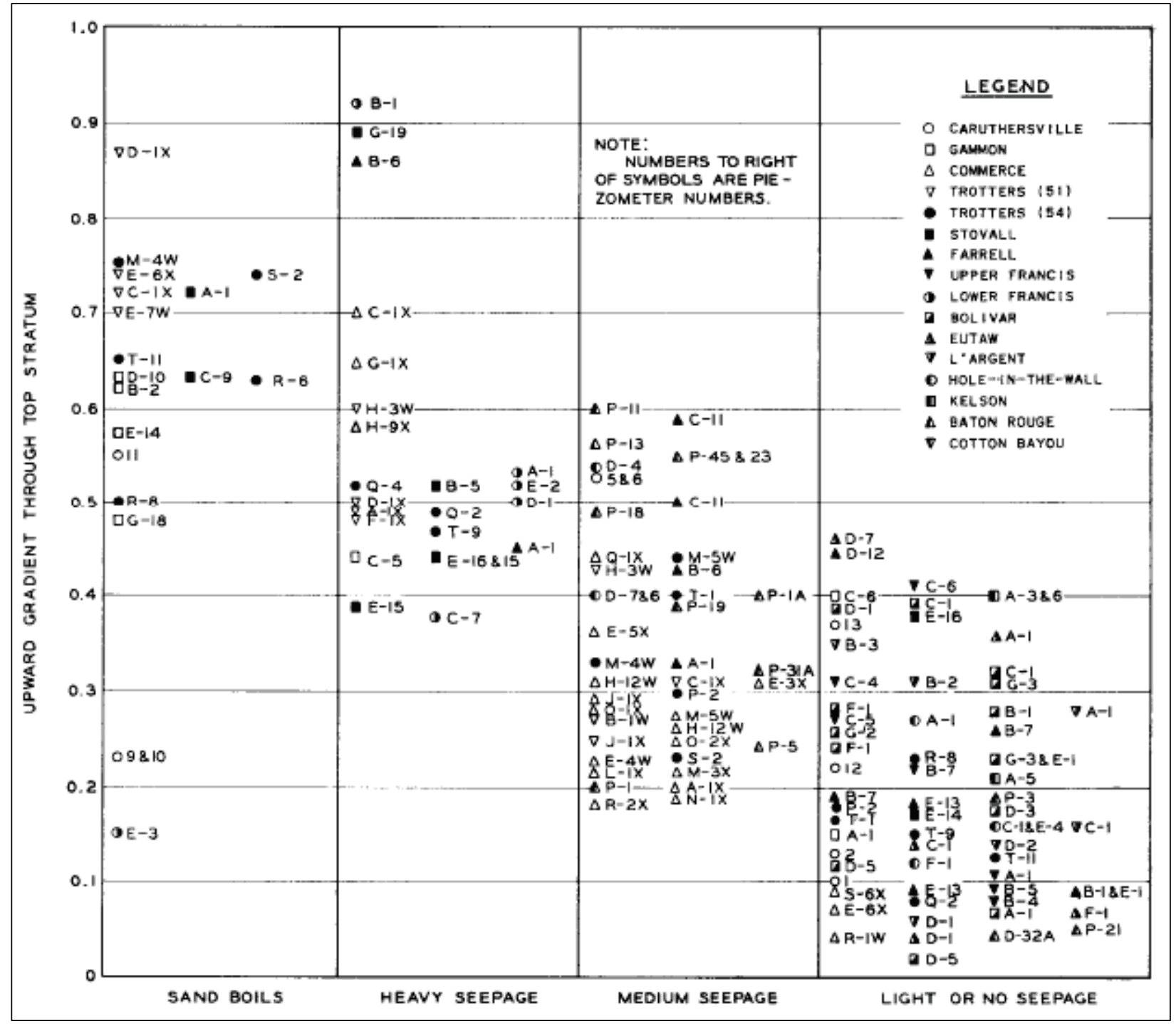

\subsection{USACE seepage criteria}

Current USACE policy for seepage control measures has evolved since the Preston levees were originally upgraded to federal standards in 1956.

Current seepage criteria recommend a minimum seepage berm width of $150 \mathrm{ft}(45.7 \mathrm{~m})$ for exit gradients between 0.5 to 0.79 and above this value, no more than 300- to 400-ft-(91.4- to 121.9-m-) wide truncated berms for gradients at the toe of the berm less than 0.8 (USACE 2000, 2005). This policy evolved after 1962 following the Mississippi River Commission (MRC) internal staff study review of berm design in the LMV, which subsequently modified seepage control design (USACE 1956a, 1962). This staff study review by the MRC would later be incorporated into the current 
Engineer Manual (EM) for levee design and construction (USACE 2000, 2005).

\subsection{Conditions at the Preston site}

Piezometers installed in 2014 and boring data from this site permit computation of the exit gradient for past floods to better understand the hydraulic gradients leading to and forming the large boils at this location. Piezometer data since December 2014 from the Preston site have recorded daily groundwater measurements for two cycles of annual flooding on the Mississippi River, including the January 2016 Flood, which was nearly comparable in magnitude to the 1993 Flood. Thus, the levee system has experienced a design flood event.

The groundwater record from the Preston area will be used as a proxy to better understand conditions that led to sand boil formation at this location in 2013. It will be assumed that the large sand boils at the Preston site were formed during this flood event based on their discovery in 2013. However, this assumption is probably not entirely valid, as most seepage and sand boil problems are usually chronic in nature and evolve with time (i.e., initially pin boils, followed by progression of small-, medium-, and eventually large-diameter boils). Nevertheless, the underlying assumption for purposes of this discussion is that these large sand boils were formed during a single flood event in 2013.

A summary review of the physical conditions at the Preston site is described first before evaluating the hydraulic loading conditions. The topographic profile in Figure 8 shows a variable ground surface across the levee section at the Preston site. This elevation profile displays the classic ridge (sandbars) and swale (or chutes) topography characteristic of a meandering river, such as the Middle Mississippi. The large swale or chute channel on the floodside levee toe extends to at least elevation $336 \mathrm{ft}$ (112 m) and likely deeper into the underlying aquifer sands, as shown by Figure 8 .

Aquifer sands extend laterally across the alluvial valley of the Middle Mississippi River and extend well behind the levee system to the limits of the rock-walled valley (Woerner et al. 2003). Thus, favorable chronic seepage and sand boil conditions at the Preston site are controlled by a nearby entry point for seepage at both the Mississippi River channel and the deep swale/chute channel adjacent to the riverside levee toe, the presence of a thin landside blanket, and fairly large hydraulic gradients 
that can develop over a short length and are capable of moving foundation sands from the underlying deep aquifer.

\subsection{6 flood aquifer loading}

The record river stage at the Grand Tower gage at the peak of the 2016 Flood was about $33 \mathrm{ft}(10 \mathrm{~m})$ higher than the ground surface behind the levee (Figure 32). As shown by the cross sections in Figures 47 through 50, the ground surface elevation is at $340 \mathrm{ft}(103.6 \mathrm{~m}) \mathrm{msl}$. Similarly, the groundwater elevation recorded in the levee toe piezometer during the 2016 Flood crest was 11 to $14 \mathrm{ft}$ ( 3.4 to $4.3 \mathrm{~m}$ ) higher than the surrounding ground surface, depending on the exact location behind the levee (see Figures 8 and 32). However, this difference factors in neither the head loss that occurs between the piezometer at the toe and the lower-lying protected areas nor the tailwater that concentrates from seepage in lowlying areas (Figure 29). Effects of tailwater will be evaluated later.

The plot of water level in Figure 32 identifies low river stages occurring in February and December 2015, with measured groundwater levels near elevation $329 \mathrm{ft}(100.3 \mathrm{~m})$. The maximum difference between low and high river stages at the Preston site in Figure 32 is nearly $40 \mathrm{ft}(12.2 \mathrm{~m})$. The corresponding difference in the groundwater elevation is about $23 \mathrm{ft}$ (7.0 m) between early December 2015 and the peak flood level in January 2016. Both of the piezometers at the levee crest and the land side toe display a similar response pattern, with a corresponding loss in head because of their increased distance from the river.

The plot of water level versus piezometer response in Figure 32 identifies the waterside piezometer (labeled A) as being submerged at elevation $350 \mathrm{ft}(106.7 \mathrm{~m})$. Thus, this instrument is no longer accurately measuring the water level above this elevation. The floodside piezometer has a vented cap, which fills above elevation $350 \mathrm{ft}(106.7 \mathrm{~m})$. Consequently, water level values above the $350-\mathrm{ft}(106.7-\mathrm{m})$ elevation mark follow the general river trend in the "A" piezometer but probably no longer accurately measure the groundwater response above this point. Therefore, only the $\mathrm{B}$ and $\mathrm{C}$ series piezometers, crest and land side toe, respectively, are considered here for purposes of determining the head loss and the exit gradient in the vicinity of the boil area during the 2016 Flood and for estimating hydraulic conditions occurring during the 2013 Flood, when the large boils were interpreted to have formed. 


\subsection{6 exit gradient at Preston}

Derivation of the exit gradient based on piezometer data assumes that head loss is constant between the $\mathrm{B}$ and $\mathrm{C}$ series piezometers (crest and land side toe hydraulic gradient, respectively); this decrease in head is linear with increased distance from the land side levee toe and eventually intersects the ground surface. Thus, the head loss for groundwater in the low-lying area where boil activity was concentrated is approximately $0.935 \mathrm{ft}(28 \mathrm{~cm})$ per $100 \mathrm{ft}(30.5 \mathrm{~m})$ from the levee crest for the 2 January 2016 Flood peak. Based on this simple approach, the hypothetical piezometer elevation in the vicinity of the sand boil area for the 2 January 2016 peak was at $350.01 \mathrm{ft}(106.7 \mathrm{~m})$ and a reduction of $1.87 \mathrm{ft}(0.57 \mathrm{~m})$ from levee crest with distance of $200 \mathrm{ft}(61 \mathrm{~m})$. Thus, the excessive head $\left(h_{o}\right)$ in the vicinity of the sand boils was $10 \mathrm{ft}(3.0 \mathrm{~m})$, using an average value of $340 \mathrm{ft}(103.6 \mathrm{~m})$ for the ground surface elevation in this area.

Blanket thickness $(z)$ beneath the Preston site determined from CPT data is between 10 and $12 \mathrm{ft}$ ( 3.0 and $3.7 \mathrm{~m}$ ) locally in this area (see Figure 45). Thus, the exit gradient $\left(h_{o} / z\right)$ calculated for this location ranges from 0.83 to 1, using results of the 2016 piezometer data. Again, this range does not account for the presence of a tailwater that normally occurs at this location during flooding due to severe seepage (Figure 29).

\subsection{6 design values for station 752 to 765}

The exit gradient estimated for the 2016 Flood level at this location is fairly close to published design values for the maximum flood event in the original levee design report (USACE 1956b). The profile for levee station 752 to 765 in the Preston levee district has a maximum design value identified for the residual head $\left(h_{o}\right)$ at $13.4 \mathrm{ft}(4 \mathrm{~m})$ and a blanket thickness ( $\mathrm{z}$ ) value of $12.5 \mathrm{ft}(3.81 \mathrm{~m})$, which yields an exit gradient $\left(i_{0}\right)$ of 1.07 for this reach, well above today's levee design standards and even those that were used in 1956 (Figure 56). As shown by the reported values in Figure 56, the allowable residual head with proposed relief wells installed per the 1956 design standard would have been $8.4 \mathrm{ft}(2.6 \mathrm{~m})$, or an exit gradient of 0.67 . Proposed relief wells in this reach were to have provided a 5 - $\mathrm{ft}(1.5-\mathrm{m})$ head relief. The original design standard for seepage control measures for the Alton-to-Gale levees was whether the "upward gradient through the top stratum landward of the levee would equal 0.85 with a river stage at the net grade of the levee" (USACE 1956b). 
Figure 56. Design data for exit gradient values (USACE 1956b).

\begin{tabular}{|c|c|c|c|c|c|c|c|c|c|c|c|c|c|c|}
\hline \multicolumn{15}{|c|}{$\begin{array}{l}\text { Preston }- \text { Ware, IL, boils between station } 760 \text { to } 770 \\
\text { USACE (1956) design data for exit gradient }\left(i_{0}\right) \text { values }\end{array}$} \\
\hline \multicolumn{2}{|c|}{ stattrou } & \multirow{2}{*}{ 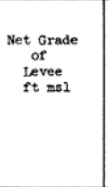 } & \multirow{2}{*}{ 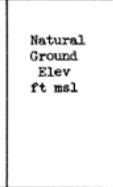 } & \multirow{2}{*}{ 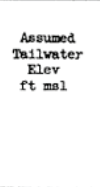 } & \multirow{2}{*}{ 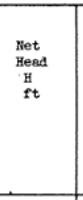 } & \multirow{2}{*}{ 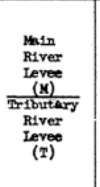 } & \multirow{2}{*}{ 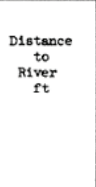 } & \multirow{2}{*}{ 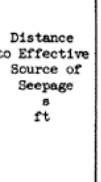 } & \multirow{2}{*}{ 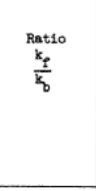 } & \multirow{2}{*}{ 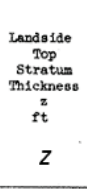 } & \multirow{2}{*}{ 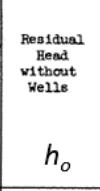 } & \multirow{2}{*}{ 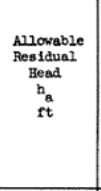 } & \multirow{2}{*}{ 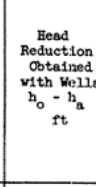 } & \multirow{2}{*}{ 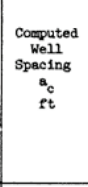 } \\
\hline Prom & to & & & & & & & & & & & & & \\
\hline 694 & 723 & 365.0 & 344.0 & 344.0 & 21.0 & $M$ & 2600 & 800 & 1000 & 10.0 & 11.1 & 6.7 & 4.4 & 235 \\
\hline \multirow[t]{3}{*}{752} & 765 & 365.0 & 341.0 & 341.0 & 24.0 & $M$ & 2900 & 800 & 1000 & 12.5 & 13.4 & 8.4 & 5.0 & 250 \\
\hline & \multirow{2}{*}{\multicolumn{14}{|c|}{$\begin{array}{l}\text { riginal } 1956 \text { design values (see above }- \text { highlighted in yellow): } i_{o}=h_{o} / z=13.4 / 12.5=1.072 \\
\text { alue range calculated from } 2016 \text { piezometer data: } i_{o}=h_{o} / z=10 / 10=1.0 \text { (or } 0.83 \text { with } z=12 \mathrm{ft} \text { ) }\end{array}$}} \\
\hline & & & & & & & & & & & & & & \\
\hline
\end{tabular}

The estimate of the exit gradient from the 2016 piezometer data does not account for the tailwater that normally accumulates in this low-lying area, which would reduce these maximum values. USACE (1976), in evaluating seepage controls for the Preston levee after the 1973 Flood, observed that "the absence of critical underseepage problems is attributed to excessive interior impoundment."

USACE (1976) further states that seepage remediation by local interests is "questionable whether well installation without simultaneous pump station construction would be acceptable." Any proposed remediation for this reach after 1976 would have adopted current design standards. The USACE remediation policy for this reach requires local levee district cooperation and cost sharing or the case to support a design deficiency.

The net effect of the tailwater condition is to reduce the maximum hydraulic gradient. Thus, every $1 \mathrm{ft}$ of water that accumulates in the low-lying area reduces the exit gradient by nearly $\sim 0.1$, based on the computed gradient and excess head at this location.

\subsection{3 exit gradient conditions}

Piezometer data from Preston will be used as a proxy to estimate conditions that led to sand boil formation in 2013. The underlying assumption here for purposes of this discussion is that the large sand boils 
at the Preston site formed during the 2013 Flood crest, when the water level was at its maximum. At this point, the alluvial aquifer would have been fully pressurized and capable of producing artesian pressures needed for sand boil activity to occur.

The Grand Tower gage on the Mississippi River was at flood stage (gage above $28 \mathrm{ft}$ ) for 93 days beginning on 13 April and ending on 14 July 2013. The crest occurred on 6 June 2013 with a gage reading of $46.24 \mathrm{ft}(14.1 \mathrm{~m})$ (elevation $368.17 \mathrm{ft}$ (112.2 m) National Gulf Vertical Datum (NGVD)29). The gage record identifies 10 days ( 3 - 12 June 2013) with readings above $40 \mathrm{ft}(12.1 \mathrm{~m})$ (elevation $361.93 \mathrm{ft}$ (110.32 m) NGVD29). This flood is similar in duration and magnitude to the 2015 Flood, which has instrumented groundwater data at the Preston site. The 2015 Flood will be used as a proxy to estimate groundwater conditions responsible for large sand boil formation at the Preston site (Figure 32).

The peak groundwater response for the 2015 Flood lags the river crest, with a maximum groundwater elevation 18 days after maximum river stage. Maximum groundwater elevation occurred on 24 June 2016. The maximum groundwater elevation for the crest and land side piezometers is 349.01 (106.4 m) and 348.61 ft (106.3 m) NGVD29, respectively. Head loss is approximately $0.645 \mathrm{ft}(19.7 \mathrm{~cm})$ per $100 \mathrm{ft}(30.5 \mathrm{~m})$ from the levee crest where boil activity was concentrated for the 2013 Flood. Thus, an excess head $\left(h_{o}\right)$ of $7.32 \mathrm{ft}(2.23 \mathrm{~m})$ occurs in the vicinity of the large sand boils, which corresponds to an exit gradient of 0.73 for a $10-\mathrm{ft}(3.1-\mathrm{m})$ blanket or 0.61 for a $12-\mathrm{ft}-(3.65-\mathrm{m}-)$ thick blanket. This range is commensurate with values in Figure 55 reported for boil activity.

\subsection{Tailwater effects}

The impact of tailwater must also be accounted for in a discussion regarding exit gradient. A sand cone height of $2 \mathrm{ft}(0.61 \mathrm{~m})$ indicates that the tailwater level was at least $2 \mathrm{ft}(0.61 \mathrm{~m})$, and the water level was approximately equivalent to the cone height. For the 2013 Flood, the impact of a 2-ft- (0.61-m-) high tailwater would lessen the gradient to 0.53 . This reduced value is near the empirical boundary for sustainment of sand boil activity in Figure 55 .

However, values of exit gradient for initiation and sustainment are likely quite different. The accumulation of underseepage to produce tailwater in low-lying areas probably lags the aquifer pressurization stage and 
development of the underseepage process during a large flood event, where steady-state seepage conditions apply. It is anticipated that this lag process will cause a change in the exit gradient value with time and directly affect sand boil initiation, progression, and sustainment.

Seepage through the blanket on the rising limb of the flood hydrograph is first concentrated along defects and any preferred pathways that exist. Maximum gradients likely occur early in the flood cycle, after aquifer pressurization occurs. This point is probably near the flood peak on the rising limb of the flood hydrograph, where tailwater conditions are at a minimum. At this point in the flood cycle, active cone development begins with movement of foundation sands to the surface.

Maximum tailwater accumulation and reduction in the hydraulic gradient likely occur during the later stages of flooding, after the flood peak occurs, and during the falling limb of the flood hydrograph. Consequently, sustainment of sand boil activity follows but under a lower gradient as compared to the initiation stage. This change in hydraulic gradient may affect seepage velocity and transport capabilities of grain size through time.

\subsection{Summary}

This section has reviewed hydraulic factors involved with sand boil initiation, progression, and sustainment at the Preston site. Conditions responsible for the sand boils identified in November 2013 are inferred from the results of the field studies performed and groundwater data measured from nearby piezometers during two flood cycles. Flood conditions in January 2016 were compared to design values by using groundwater data and were found to be near the original design values for the exit gradient without the proposed relief well reduction. The January 2016 Flood was a major flood and tested the levee system.

Exit gradient has been used by USACE for the construction of underseepage control measures to remediate against potential internal erosion. Seepage control measures typically involve seepage berms and relief wells. The original design standard used to evaluate the levee for seepage control measures was whether the "upward gradient through the top stratum landward of the levee would equal 0.85 with a river stage at the net grade of the levee" (USACE 1956a). The allowable residual head with proposed relief wells installed under the 1956 design would have been $8.4 \mathrm{ft}(2.56 \mathrm{~m})$, or an exit gradient of 0.67 , with a 5 - $\mathrm{ft}(1.52-\mathrm{m})$ head relief 
from these wells. Original design criteria are no longer valid, and current design criteria warrant further attention due to the current severity of sand boils at this location.

Relief wells in the Preston reach studied were never installed because of landowner opposition of seepage onto valuable farm lands. A systematic review of seepage design was performed following the 1973 Flood, but the proposed relief wells and a pump station to control underseepage were never installed (USACE 1976).

The 2015 groundwater record from the Preston area was used as a proxy to better understand conditions that led to sand boil formation at this location in 2013. It was assumed that the large sand boils at the Preston site were formed during this single flood event, based on their discovery after the annual flood cycle in 2013. However, sand boil activity is typically associated with chronic seepage conditions because of the site geology and blocked exit conditions locally. These areas tend to progress with time in terms of severity during large flood events.

Sand boil activity at the Preston site in 2013 was estimated to have occurred near the flood crest, with exit gradient of 0.61 to 0.73 . These values are consistent with empirical studies of exit gradient and large sand boil activity in the LMV (USACE 1941, 1956b). Current USACE seepage control standards would design countermeasures to reduce the exit gradient for this levee location because of the large boils present.

Sand boil problems in the Preston reach are large enough to warrant remediation and seepage control measures. Tailwater conditions have likely prevented the sand boils from becoming more severe sooner and indicate chronic seepage conditions have likely progressed through time to their present condition. Tailwater accumulation in the low-lying area reduces the hydraulic gradient in these low-lying areas. However, maximum tailwater conditions likely tend to lag the river crest when gradients are highest. Consequently, the time lag for a large tailwater to develop does not lessen the initial sand boil initiation process and progression phase. 


\section{Summary and Conclusions}

\subsection{Summary}

This report documents a case history of internal erosion and sand boil activity at the Preston levee site, near the town of Ware, in southern Illinois. Conditions responsible for the sand boils identified in November 2013 are inferred from the results of field studies performed and groundwater data measured from nearby piezometers during two flood cycles. An important boundary for levee engineering and underseepage potential is the character and thickness of the top stratum. The direction of the levee system and the orientation of the underlying geology are contributing factors for seepage potential. The presence of a blocked exit condition and other site defects can increase the aquifer pressure and localize excessive underseepage and sand boil activity.

Field investigations were performed to determine the geology, site stratigraphy, sand boil characteristics, and groundwater conditions that occurred to determine causes for the 2013 sand boils at Preston. CPT characterization of the Preston site identified top stratum or blanket thickness, associated soil types, and other aspects of the underlying stratigraphy.

Closely spaced resistivity surveys of the subsurface were able to image the top stratum to determine characteristics of the stratigraphy, its thickness, and any disturbances caused by seepage pathways beneath sand boil sites. Resistivity surveys show high resistivity soils (consistent with the presence of resistive aquifer sands) near the surface and the presence of sheet sands deposited from multiple sand boils. These sheet sands were in turn overlain by a conductive fine-grained clay layer.

Researchers examined historic design and exit gradient data as part of this study to understand the occurrence of seepage and sand boil activity at the Preston site. Values obtained from the 1956 levee design report were compared to values calculated from the 2013 and 2016 Flood data, using the daily groundwater record from piezometers at this site. These data were further compared to empirical data obtained by USACE (1956b) to mitigate underseepage control behind levees. Studies by USACE (1956a, 1956b, 1962, 2000) were used to establish seepage control policy for levees. 


\subsection{Conclusions}

A blocked exit condition was found to exist at the Preston site, which has concentrated underseepage locally due to the presence of a prominent west-to-east trending buried swale and its nearly right angle junction with the levee. Blocked exit conditions at this location cause abrupt changes in hydraulic conductivity in the shallow aquifer and concentrate underseepage locally. Sand boils at the Preston site are located upstream of this buried swale.

Based on the results of the field studies that were performed, a model of sand boil development is proposed for the Preston site. Sand boil formation at Preston occurs as a two-stage process. Sand boils are inferred to have formed under submerged conditions in low-lying areas where seepage concentrates. Sand movement and active cone development occur immediately after aquifer pressurization, during the rising limb of the flood hydrograph. This phase is later followed by settlement of finegrained soils from suspension after active underseepage flow has waned, during the falling limb of the hydrograph. Maximum cone development and elevation are governed by tailwater level, which aids in transport of sheet sands adjacent to the cone.

The 2015 groundwater record from the Preston area was used as a proxy to better understand exit gradients that led to sand boil formation at this location in 2013. The 2015 Flood was similar in terms of river stage and duration to the 2013 Flood. Sand boil activity at the Preston site in 2013 was estimated to have occurred near the flood crest with an exit gradient between 0.61 to 0.73 and with blanket thickness between 12 to $10 \mathrm{ft}$ (3.6 to $3.0 \mathrm{~m}$ ). This range in blanket thickness is commensurate with local geologic conditions. These values are consistent with empirical studies of exit gradient and large sand boil activity in the LMV (USACE 1941, 1956b). Current USACE seepage control policy would recommend design countermeasures to reduce the exit gradient for this levee location because of the large boils present. However, the original 1956 levee design for this reach allowed for higher exit gradients than those in practice today.

An underlying assumption for this study was that the large sand boils present at the Preston site were formed during a single flood event, based on their discovery after the annual flood cycle in 2013. However, sand boil activity is typically associated with chronic seepage conditions because of the underlying site geology, levee orientation with the geology, and 
blocked exit conditions. Thus, activity in these areas tends to progress through time in terms of its severity and response to medium-to-large flood events.

Seepage control measures were never installed at the Preston site because of local landowner opposition to relief well drainage onto valuable agricultural lands. The absence of past sand boil problems in the Preston reach is attributed to excessive interior impoundment from underseepage (USACE 1976). Tailwater accumulation occurs in the low-lying area and effectively reduces the hydraulic gradient during the flood event. However, maximum tailwater conditions probably tend to lag the river crest, when gradients are highest. Consequently, the time lag for a large tailwater to develop does not reduce the initial sand boil initiation process and progression phase.

\subsection{Recommendations}

Direct observations of field conditions and water level elevations are an important part of fully understanding system response and levee performance problems. The targeted use of unmanned aerial vehicles/systems (UAV/UAS) in chronic seepage areas would greatly facilitate better understanding of sand boil activity and local conditions that are responsible.

Resistivity surveys of large sand boil areas should be continued as part of any post-flood evaluation and analysis of the performance of the levee system. These surveys should be conducted with CPT soundings to maximize the quality of the information obtained from these surveys. These studies are especially important where large boils occur and move large quantities of sand.

UAV/UAS imaging of sand boils and tailwater areas should be performed in chronic seepage areas to catalogue seepage conditions and permit direct observation of these areas for understanding boil progression. An important addition would be the use of thermal imaging technology to discriminate temperature contrasts due to the welling of groundwater in tailwater areas and to identify and target potential seepage pipes or conduits for selective measurements.

Current UAV/UAS capabilities permit construction of elevation point clouds and elevation models at sand boils and levee sites. These data can 
be compared to high-resolution LiDAR data sets to determine time lapse subsidence of the levee due to loss of foundation support. Thus, it is recommended that these type of data should be routinely collected from large sand boil sites to determine any vertical changes that are occurring.

Seepage velocity is poorly documented at large sand boils and not well calibrated in terms of the exit gradient at these sand boil sites. Thus, both direct and indirect methods to measure velocity and other parameters of interest are needed in order to obtain specific measurements during active flooding.

Properties of sand boil ejecta are an important data point to determine their source in the stratigraphic column and indirect evidence of particle velocity. Samples should be collected and catalogued to provide a database of properties and characteristics.

Trenching of sand boil locations, along with other methods described in this report, should be performed following medium-to-large floods to directly observe the seepage pathways and ejecta being transported. These soils should be sampled and further compared to ejecta samples from the surface.

Mobile Information Collection Application (MICA) data were compiled from flooding in 2013 and were used to identify the Preston site for study. Thus, after-action flood maps showing the locations of sand boils, seepage conditions (low, moderate, and heavy) and adverse levee stability slides should be compiled to document levee performance following each flood. These maps should be evaluated in terms of their spatial and temporal occurrence to evaluate both short- and long-term trends in terms of levee performance and characteristics of internal erosion. This information in conjunction with field measurements from large sand boils will provide a valuable data set to build on USACE 1956b studies.

Enterprise geographic information system technology (EGIS) easily facilitates this transfer of information within USACE districts and ERDC research labs. Toward this goal, it is recommended that USACE districts easily share access to this information across USACE commands. ERDC partnership with USACE districts is necessary to collect performance data from large flood events to develop better risk models of levee performance. 


\section{References}

Devera, J. A. 1993. Geologic map of the Wolf Lake Quadrangle Jackson and Union Counties, Illinois. Map IGQ-13. Champaign, IL: Illinois State Geologic Survey.

Frankie, W. T., J. A. Devera, and M. Seid. 2008. Guide to the geology of the Horseshoe Lake State Conservation area and surrounding area, Alexander County, Illinois. Champaign, IL: Illinois State Geological Survey.

Palacky, G. J. 1988. Resistivity characteristics of geologic targets. Chap. 3 in Electromagnetic methods in applied geophysics: Volume 1, theory, investigations in geophysics, ed. M. N. Nabighian, 53-129. Society of Exploration Geophysicists. https://doi.org/10.1190/1.9781560802631.ch3.

Robertson, P. K., R.G. Campanella, D. Gillespie, and J. Greig. 1986. Use of piezometer cone data: In-situ 8. Use of in-situ testing in geotechnical engineering. Specialty Publication, GSP 6: 1263-1280. Reston, VA: American Society of Civil Engineers.

Seid, M. J. 2013. Bedrock geology of Kaskaskia Quadrangle, Randolph County, Illinois, and Ste. Genevieve and Perry Counties, Missouri. Champaign,IL: Illinois State Geological Survey.

Turnbull, W. J., and C. I. Mansur. 1961. Investigation of underseepage-Mississippi River levees. Transactions, ASCE 126(1):1429-1485.

U.S. Army Corps of Engineers (USACE). 1941. Investigation of underseepage Lower Mississippi River levees. Technical Memorandum 184-1. Vicksburg, MS: USACE Waterways Experiment Station.

------. 1947. Code for utilization of soils data for levees. Vicksburg, MS: Mississippi River Commission.

------. 1956a. Investigation of underseepage and its control, Lower Mississippi River. Technical Memorandum No. 3-424, Vols. I and II. Vicksburg, MS: USACE Waterways Experiment Station.

-----. 1956b. Investigation of underseepage Mississippi River levees, Alton to Gale, IL. Technical Memorandum No. 3-430, Vols. I and II. Vicksburg, MS: USACE Waterways Experiment Station.

------. 1962. Review of design criteria for landside seepage berms for Mississippi River levees. Memo. 19 November 1962. Vicksburg, MS: Mississippi River Commission.

------. 1976. Re-evaluation of underseepage controls, Mississippi River Levees, Alton to Gale, IL: Phase 1, Performance of underseepage controls during the 1973 Flood, Vol. I. St. Louis, MO: U.S. Army Corps of Engineers.

------. 2000. Design and construction of levees. EM 1110-2-1913. Washington, DC: Department of the Army.

------. 2005. Design guidance for levee underseepage. ETL 1110-2-569. Washington, DC: Department of the Army. 
U.S. Department of Agriculture (USDA).2015. Natural Resources Conservation Service. Web Soil Survey. http://websoilsurvey.nrcs.usda.gov/. Accessed May 12, 2015.

Woerner, E. G., J. B. Dunbar, E. Villanueva, and L. M. Smith. 2003. Geologic investigation of the Middle Mississippi River. ERDC/GSL Technical Report TR03-7. Vicksburg, MS: U. S. Army Engineer Research and Development Center.

Wolff, T. F. 2002. Performance of levee underseepage controls: A critical review. ERDC/GSL TR-02-19. Washington, DC: USACE Engineer Research and Development Center. 


\section{Appendix A: Soil Curves from Ejecta Samples from Sand Boil Cones}




\section{PR-1A:}

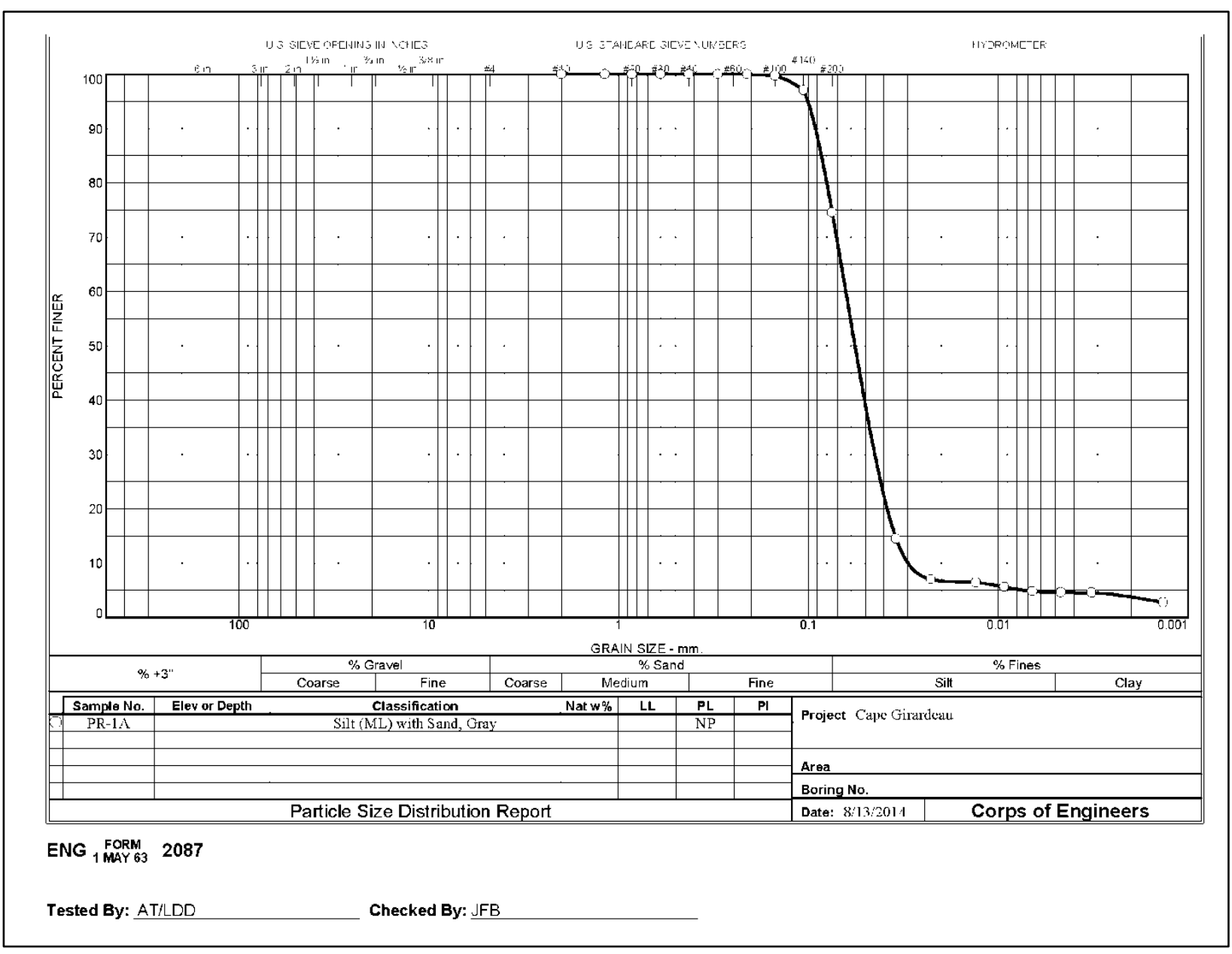


Project: Cape Girardeau

Sample Number: PR-1A

Material Description: Silt (ML) with Sand, Gray

PL: NP

Tested by: AT/LDD

Checked by: JFB

\begin{tabular}{|c|c|c|c|c|c|}
\hline \multirow[b]{2}{*}{$\begin{array}{c}\text { Dry } \\
\text { Sample } \\
\text { and Tare } \\
\text { (grams) }\end{array}$} & \multirow[b]{2}{*}{$\begin{array}{c}\text { Tare } \\
\text { (grams) }\end{array}$} & & \multicolumn{2}{|c|}{ Sieve Test Data } & \multirow[b]{2}{*}{$\begin{array}{l}\text { Percent } \\
\text { Finer }\end{array}$} \\
\hline & & $\begin{array}{l}\text { Cumulative } \\
\text { Pan } \\
\text { Tare Weight } \\
\text { (grams) }\end{array}$ & $\begin{array}{l}\text { Sieve } \\
\text { Opening } \\
\text { Size }\end{array}$ & $\begin{array}{l}\text { Cumulative } \\
\text { Weight } \\
\text { Retained } \\
\text { (grams) }\end{array}$ & \\
\hline \multirow[t]{10}{*}{79.40} & 0.00 & 0.00 & $\# 10$ & 0.00 & 100.0 \\
\hline & & & $\# 16$ & 0.00 & 100.0 \\
\hline & & & $\# 20$ & 0.00 & 100.0 \\
\hline & & & $\# 30$ & 0.00 & 100.0 \\
\hline & & & $\# 40$ & 0.00 & 100.0 \\
\hline & & & $\# 50$ & 0.00 & 100.0 \\
\hline & & & $\# 70$ & 0.00 & 100.0 \\
\hline & & & $\# 100$ & 0.20 & 99.7 \\
\hline & & & $\# 140$ & 2.30 & 97.1 \\
\hline & & & $\# 200$ & 20.20 & 74.6 \\
\hline
\end{tabular}

Hydrometer test uses material passing $\# 10$

Hydrometer Test Data

Percent passing $\# 10$ based upon complete sample $=100.0$

Weight of hydrometer sample $=79.4$

Automatic temperature correction

Composite correction (fluid density and meniscus height) at $20 \mathrm{deg} . \mathrm{C}=-4.7$

Meniscus correction only $=-0.5$

Specific gravity of solids

Hydrometer type $=151 \mathrm{H}$

$\begin{array}{ccccccccc}\begin{array}{c}\text { Elapsed } \\ \text { Time (min.) }\end{array} & \begin{array}{c}\text { Temp. } \\ \text { (deg. C.) }\end{array} & \begin{array}{c}\text { Actual } \\ \text { Reading }\end{array} & \begin{array}{c}\text { Corrected } \\ \text { Reading }\end{array} & \mathrm{K} & \mathbf{R m} & \begin{array}{c}\text { Eff. } \\ \text { Depth }\end{array} & \begin{array}{c}\text { Diameter } \\ (\mathbf{m m} \text { ) }\end{array} & \begin{array}{c}\text { Percent } \\ \text { Finer }\end{array} \\ 2.00 & 21.0 & 1.0118 & 1.0072 & 0.0134 & 11.3 & 13.3 & 0.0346 & 14.5 \\ 5.00 & 21.0 & 1.0081 & 1.0035 & 0.0134 & 7.6 & 14.3 & 0.0226 & 7.1 \\ 15.00 & 21.0 & 1.0078 & 1.0032 & 0.0134 & 7.3 & 14.4 & 0.0131 & 6.5 \\ 30.00 & 21.0 & 1.0074 & 1.0028 & 0.0134 & 6.9 & 14.5 & 0.0093 & 5.7 \\ 60.00 & 21.0 & 1.0070 & 1.0024 & 0.0134 & 6.5 & 14.6 & 0.0066 & 4.8 \\ 120.00 & 21.0 & 1.0069 & 1.0023 & 0.0134 & 6.4 & 14.6 & 0.0047 & 4.6 \\ 250.00 & 21.5 & 1.0068 & 1.0023 & 0.0133 & 6.3 & 14.6 & 0.0032 & 4.6 \\ 1440.00 & 21.5 & 1.0059 & 1.0014 & 0.0133 & 5.4 & 14.9 & 0.0014 & 2.8\end{array}$




\begin{tabular}{|c|c|c|c|c|c|c|c|c|c|c|}
\hline \multicolumn{11}{|c|}{ Fractional Components } \\
\hline \multirow{2}{*}{ Cobbles } & \multicolumn{3}{|c|}{ Gravel } & \multicolumn{4}{|c|}{ Sand } & \multicolumn{3}{|c|}{ Fines } \\
\hline & Coarse & Fine & Total & Coarse & Medium & Fine & Total & Silt & Clay & Total \\
\hline 0.0 & 0.0 & 0.0 & 0.0 & 0.0 & 0.0 & 25.4 & 25.4 & 69.9 & 4.7 & 74.6 \\
\hline
\end{tabular}

\begin{tabular}{|c|c|c|c|c|c|c|c|c|c|}
\hline $\mathrm{D}_{\mathbf{1 0}}$ & $\mathrm{D}_{\mathbf{1 5}}$ & $\mathrm{D}_{\mathbf{2 0}}$ & $\mathrm{D}_{\mathbf{3 0}}$ & $\mathrm{D}_{\mathbf{5 0}}$ & $\mathrm{D}_{\mathbf{6 0}}$ & $\mathrm{D}_{\mathbf{8 0}}$ & $\mathrm{D}_{\mathbf{8 5}}$ & $\mathrm{D}_{\mathbf{9 0}}$ & $\mathrm{D}_{\mathbf{9 5}}$ \\
\hline 0.0299 & 0.0349 & 0.0385 & 0.0447 & 0.0569 & 0.0636 & 0.0801 & 0.0854 & 0.0918 & 0.1006 \\
\hline
\end{tabular}

\begin{tabular}{|c|c|c|}
\hline $\begin{array}{c}\text { Fineness } \\
\text { Modulus }\end{array}$ & $\mathrm{c}_{\mathbf{u}}$ & $\mathrm{c}_{\mathbf{c}}$ \\
\hline 0.00 & 2.13 & 1.05 \\
\hline
\end{tabular}




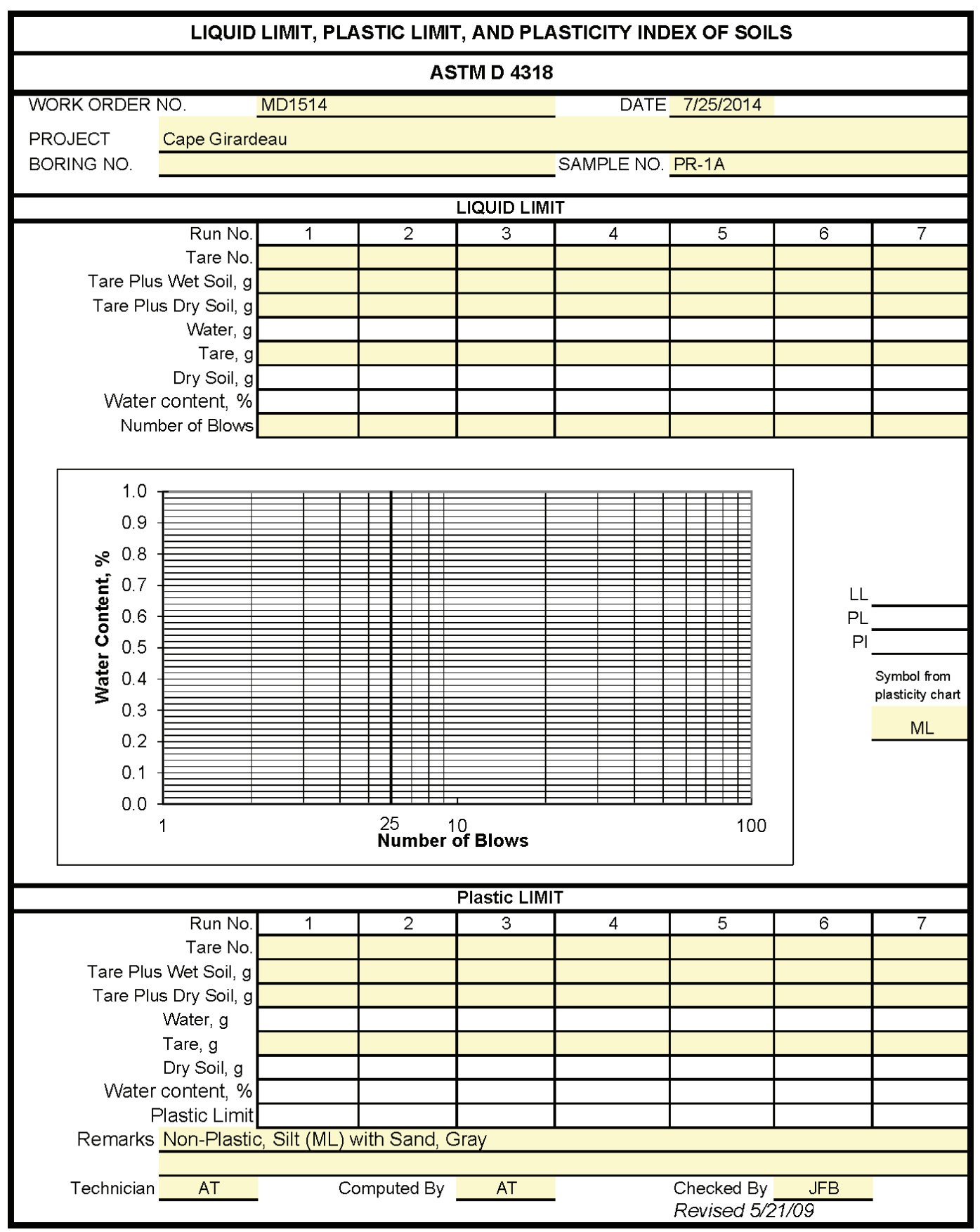




\section{PR-1A ECJ-1}

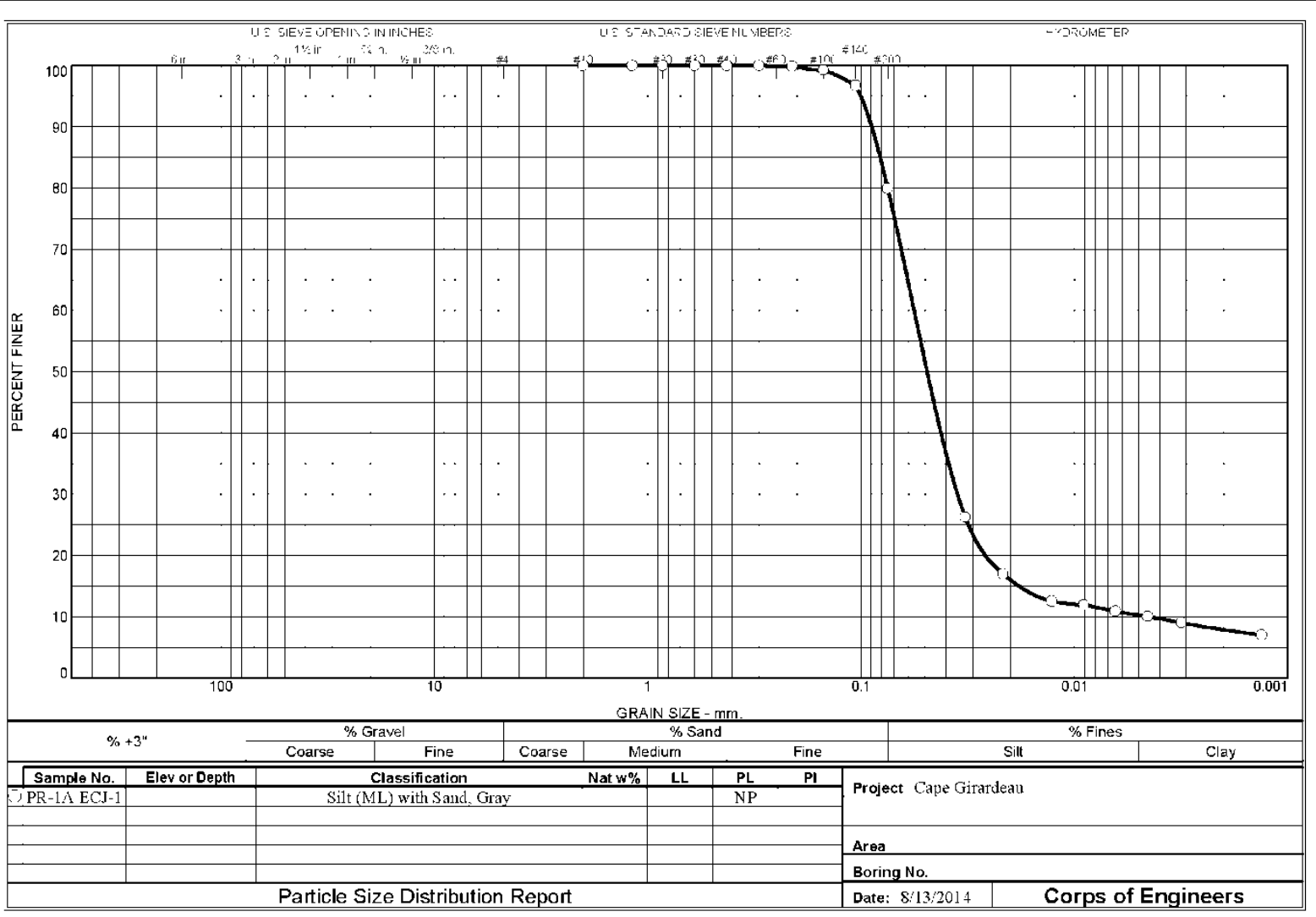

ENG 1 MAY 6332087

Tested By: AT/LDD 
Project: Cape Girardeau

Sample Number: PR-1A ECJ-1

Material Description: Silt (ML) with Sand, Gray

PL: NP

Tested by: AT/LDD

Checked by: JFB

\begin{tabular}{|c|c|c|c|c|c|}
\hline \multirow[b]{2}{*}{$\begin{array}{l}\text { Dry } \\
\text { Sample } \\
\text { and Tare } \\
\text { (grams) }\end{array}$} & \multirow[b]{2}{*}{$\begin{array}{c}\text { Tare } \\
\text { (grams) }\end{array}$} & \multicolumn{4}{|c|}{ Sieve Test Data } \\
\hline & & $\begin{array}{l}\text { Cumulative } \\
\text { Pan } \\
\text { Tare Weight } \\
\text { (grams) }\end{array}$ & $\begin{array}{c}\text { Sieve } \\
\text { Opening } \\
\text { Size }\end{array}$ & $\begin{array}{c}\text { Cumulative } \\
\text { Weight } \\
\text { Retained } \\
\text { (grams) }\end{array}$ & $\begin{array}{l}\text { Percent } \\
\text { Finer }\end{array}$ \\
\hline \multirow[t]{10}{*}{79.20} & 0.00 & 0.00 & $\# 10$ & 0.00 & 100.0 \\
\hline & & & $\# 16$ & 0.00 & 100.0 \\
\hline & & & $\# 20$ & 0.00 & 100.0 \\
\hline & & & $\# 30$ & 0.00 & 100.0 \\
\hline & & & $\# 40$ & 0.00 & 100.0 \\
\hline & & & $\# 50$ & 0.00 & 100.0 \\
\hline & & & $\# 70$ & 0.10 & 99.9 \\
\hline & & & $\# 100$ & 0.60 & 99.2 \\
\hline & & & $\# 140$ & 2.60 & 96.7 \\
\hline & & & $\# 200$ & 15.90 & 79.9 \\
\hline
\end{tabular}

Hydrometer test uses material passing $\# 10$

\section{Hydrometer Test Data}

Percent passing \#10 based upon complete sample $=100.0$

Weight of hydrometer sample $=79.2$

Automatic temperature correction

Composite correction (fluid density and meniscus height) at $\mathbf{2 0}$ deg. $C=-4.7$

Meniscus correction only $=-0.5$

Specific gravity of solids $=2.67$ est

Hydrometer type $=151 \mathrm{H}$

Hydrometer effective depth equation: $L=16.294964-0.2645 \times \mathbf{R m}$

$\begin{array}{ccccccccc}\begin{array}{c}\text { Elapsed } \\ \text { Time (min.) }\end{array} & \begin{array}{c}\text { Temp. } \\ \text { (deg. C.) }\end{array} & \begin{array}{c}\text { Actual } \\ \text { Reading }\end{array} & \begin{array}{c}\text { Corrected } \\ \text { Reading }\end{array} & \mathbf{K} & \mathbf{R m} & \begin{array}{c}\text { Eff. } \\ \text { Depth }\end{array} & \begin{array}{c}\text { Diameter } \\ \text { (mm.) }\end{array} & \begin{array}{c}\text { Percent } \\ \text { Finer }\end{array} \\ 2.00 & 21.0 & 1.0176 & 1.0130 & 0.0134 & 17.1 & 11.8 & 0.0325 & 26.3 \\ 5.00 & 21.0 & 1.0130 & 1.0084 & 0.0134 & 12.5 & 13.0 & 0.0216 & 17.0 \\ 15.00 & 21.0 & 1.0108 & 1.0062 & 0.0134 & 10.3 & 13.6 & 0.0127 & 12.5 \\ 30.00 & 21.0 & 1.0105 & 1.0059 & 0.0134 & 10.0 & 13.6 & 0.0090 & 11.9 \\ 60.00 & 21.0 & 1.0100 & 1.0054 & 0.0134 & 9.5 & 13.8 & 0.0064 & 10.9 \\ 120.00 & 21.5 & 1.0095 & 1.0050 & 0.0133 & 9.0 & 13.9 & 0.0045 & 10.0 \\ 250.00 & 21.5 & 1.0090 & 1.0045 & 0.0133 & 8.5 & 14.0 & 0.0032 & 9.0 \\ 1440.00 & 21.5 & 1.0080 & 1.0035 & 0.0133 & 7.5 & 14.3 & 0.0013 & 7.0\end{array}$




\begin{tabular}{|c|c|c|c|c|c|c|c|c|c|c|}
\hline \multicolumn{11}{|c|}{ Fractional Components } \\
\hline \multirow{2}{*}{ Cobbles } & \multicolumn{3}{|c|}{ Gravel } & \multicolumn{4}{|c|}{ Sand } & \multicolumn{3}{|c|}{ Fines } \\
\hline & Coarse & Fine & Total & Coarse & Medium & Fine & Total & Silt & Clay & Total \\
\hline 0.0 & 0.0 & 0.0 & 0.0 & 0.0 & 0.0 & 20.1 & 20.1 & 69.6 & 10.3 & 79.9 \\
\hline
\end{tabular}

\begin{tabular}{|c|c|c|c|c|c|c|c|c|c|}
\hline $\mathrm{D}_{\mathbf{1 0}}$ & $\mathrm{D}_{\mathbf{1 5}}$ & $\mathrm{D}_{\mathbf{2 0}}$ & $\mathrm{D}_{\mathbf{3 0}}$ & $\mathrm{D}_{\mathbf{5 0}}$ & $\mathrm{D}_{\mathbf{6 0}}$ & $\mathrm{D}_{\mathbf{8 0}}$ & $\mathrm{D}_{\mathbf{8 5}}$ & $\mathrm{D}_{\mathbf{9 0}}$ & $\mathrm{D}_{\mathbf{9 5}}$ \\
\hline 0.0044 & 0.0182 & 0.0262 & 0.0354 & 0.0491 & 0.0564 & 0.0751 & 0.0814 & 0.0891 & 0.1002 \\
\hline
\end{tabular}

\begin{tabular}{|c|c|c|}
\hline $\begin{array}{c}\text { Fineness } \\
\text { Modulus }\end{array}$ & $\mathrm{c}_{\mathrm{u}}$ & $\mathrm{c}_{\mathrm{c}}$ \\
\hline 0.01 & 12.69 & 4.99 \\
\hline
\end{tabular}




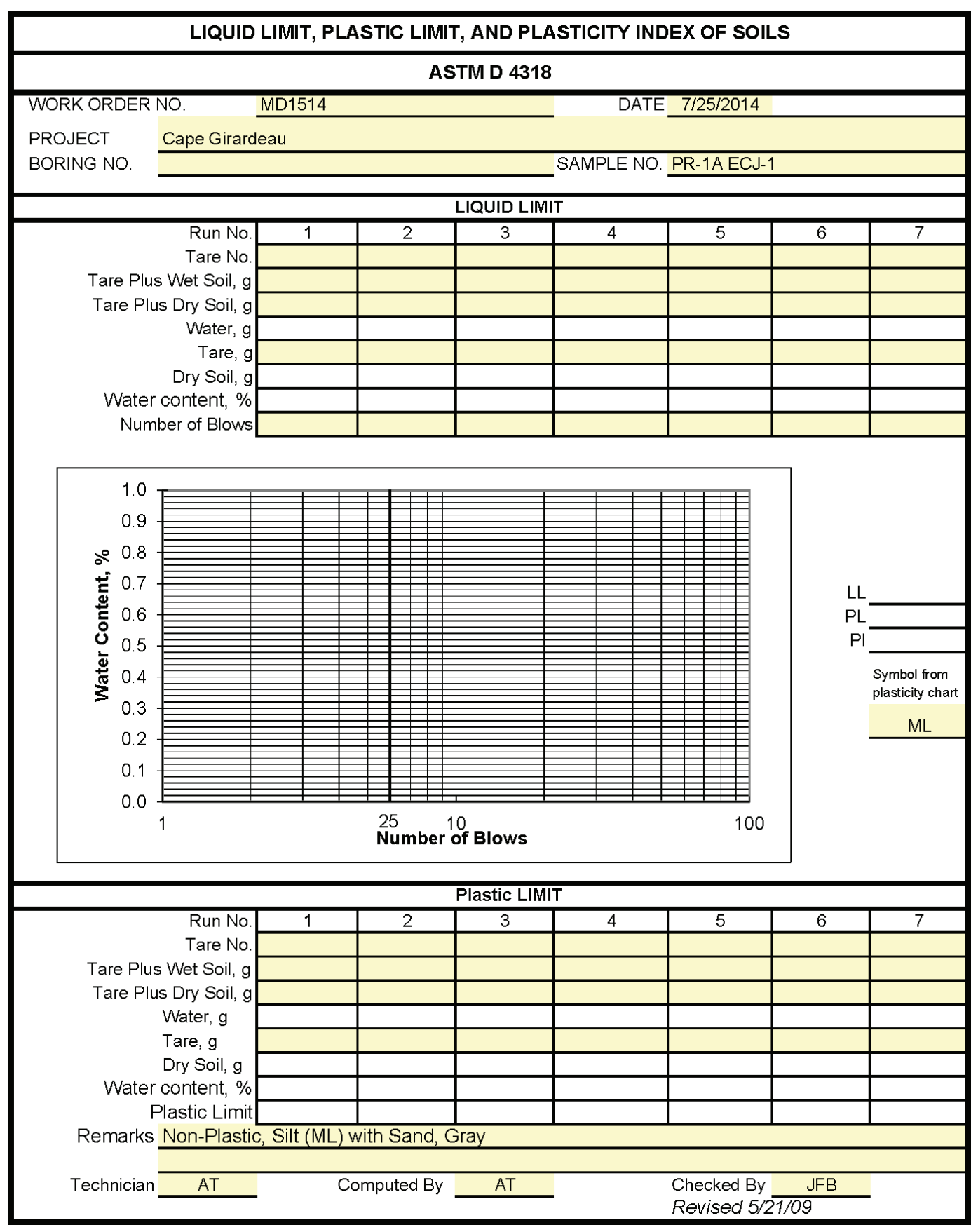




\section{PR-1B:}

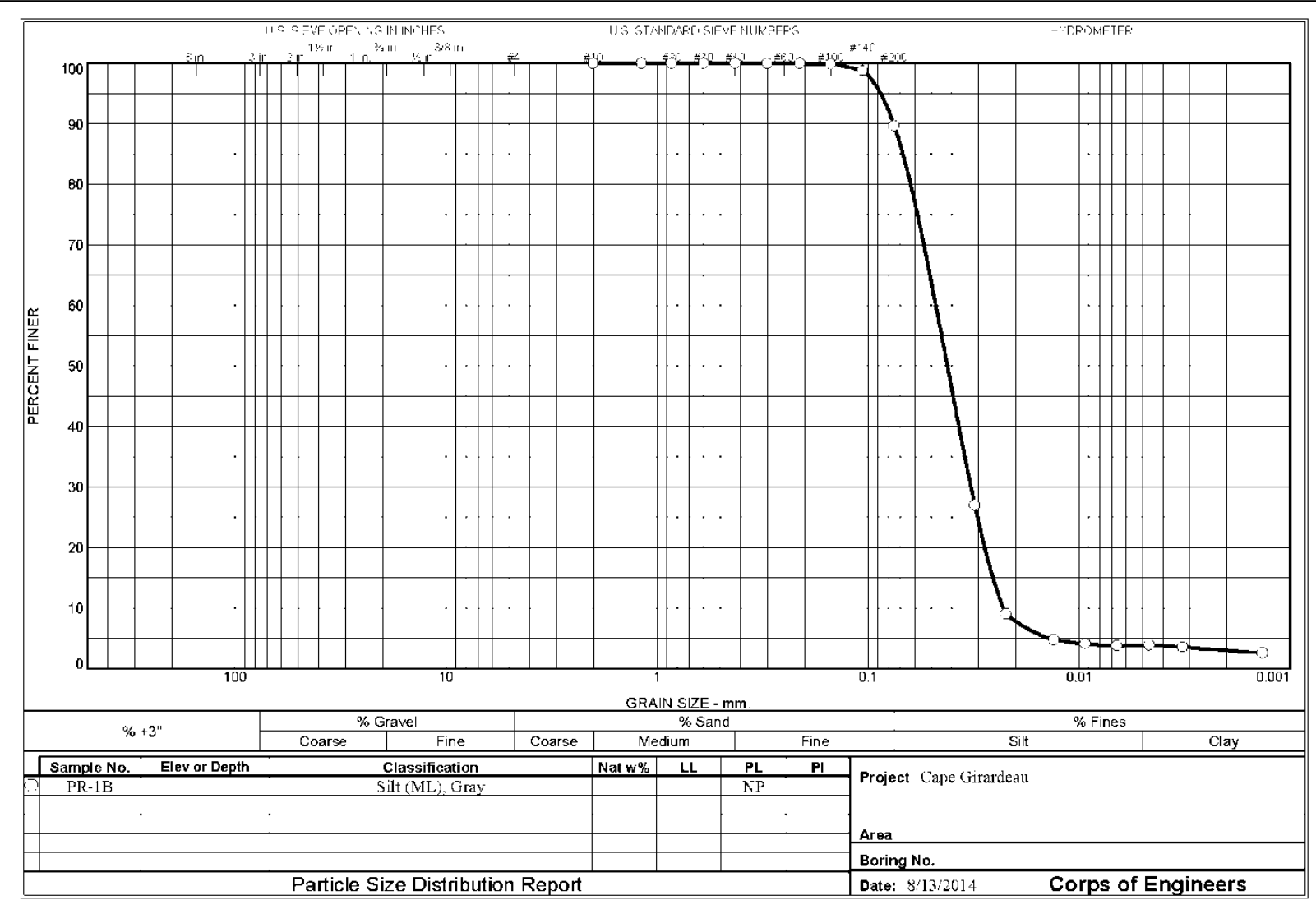

ENG 1 FORM 2087

Tested By: ATfLDD

Checked By: لJFB 
Project: Cape Girardeau

Sample Number: PR-1B

Material Description: Silt (ML), Gray

PL: NP

Tested by: AT/LDD

Checked by: JFB

\begin{tabular}{|c|c|c|c|c|c|}
\hline \multirow[b]{2}{*}{$\begin{array}{c}\text { Dry } \\
\text { Sample } \\
\text { and Tare } \\
\text { (grams) }\end{array}$} & \multirow[b]{2}{*}{$\begin{array}{c}\text { Tare } \\
\text { (grams) }\end{array}$} & \multicolumn{4}{|c|}{ Sieve Test Data } \\
\hline & & $\begin{array}{c}\text { Cumulative } \\
\text { Pan } \\
\text { Tare Weight } \\
\text { (grams) }\end{array}$ & $\begin{array}{l}\text { Sieve } \\
\text { Opening } \\
\text { Size }\end{array}$ & $\begin{array}{c}\text { Cumulative } \\
\text { Weight } \\
\text { Retained } \\
\text { (grams) }\end{array}$ & $\begin{array}{c}\text { Percent } \\
\text { Finer }\end{array}$ \\
\hline \multirow[t]{10}{*}{97.70} & 0.00 & 0.00 & $\# 10$ & 0.00 & 100.0 \\
\hline & & & $\# 16$ & 0.00 & 100.0 \\
\hline & & & $\# 20$ & 0.00 & 100.0 \\
\hline & & & $\# 30$ & 0.00 & 100.0 \\
\hline & & & $\# 40$ & 0.00 & 100.0 \\
\hline & & & $\# 50$ & 0.00 & 100.0 \\
\hline & & & $\# 70$ & 0.00 & 100.0 \\
\hline & & & $\# 100$ & 0.10 & 99.9 \\
\hline & & & $\# 140$ & 1.20 & 98.8 \\
\hline & & & $\# 200$ & 10.10 & 89.7 \\
\hline
\end{tabular}

Hydrometer test uses material passing $\# 10$

Hydrometer Test Data

Percent passing $\# 10$ based upon complete sample $=100.0$

Weight of hydrometer sample $=97.7$

Automatic temperature correction

Composite correction (fluid density and meniscus height) at 20 deg. $C=-4.7$

Meniscus correction only $=-0.5$

Specific gravity of solids $=2.67$ est

Hydrometer type $=151 \mathrm{H}$

Hydrometer effective depth equation: $L=16.294964-0.2645 \times \mathrm{Rm}$

\begin{tabular}{|c|c|c|c|c|c|c|c|c|}
\hline $\begin{array}{l}\text { Elapsed } \\
\text { Time (min.) }\end{array}$ & $\begin{array}{l}\text { Temp. } \\
\text { (deg. C.) }\end{array}$ & $\begin{array}{c}\text { Actual } \\
\text { Reading }\end{array}$ & $\begin{array}{l}\text { Corrected } \\
\text { Reading }\end{array}$ & $\mathrm{K}$ & $\mathrm{Rm}$ & $\begin{array}{l}\text { Eff. } \\
\text { Depth }\end{array}$ & $\begin{array}{c}\text { Diameter } \\
(\mathrm{mm} .)\end{array}$ & $\begin{array}{l}\text { Percent } \\
\text { Finer }\end{array}$ \\
\hline 2.00 & 21.0 & 1.0211 & 1.0165 & 0.0134 & 20.6 & 10.8 & 0.0312 & 27.0 \\
\hline 5.00 & 21.0 & 1.0101 & 1.0055 & 0.0134 & 9.6 & 13.8 & 0.0222 & 9.0 \\
\hline 15.00 & 21.0 & 1.0075 & 1.0029 & 0.0134 & 7.0 & 14.4 & 0.0131 & 4.8 \\
\hline 30.00 & 21.0 & 1.0071 & 1.0025 & 0.0134 & 6.6 & 14.5 & 0.0093 & 4.1 \\
\hline 60.00 & 21.0 & 1.0069 & 1.0023 & 0.0134 & 6.4 & 14.6 & 0.0066 & 3.8 \\
\hline 120.00 & 21.5 & 1.0069 & 1.0024 & 0.0133 & 6.4 & 14.6 & 0.0046 & 3.9 \\
\hline 250.00 & 21.5 & 1.0067 & 1.0022 & 0.0133 & 6.2 & 14.7 & 0.0032 & 3.6 \\
\hline 1440.00 & 21.5 & 1.0061 & 1.0016 & 0.0133 & 5.6 & 14.8 & 0.0014 & 2.6 \\
\hline
\end{tabular}




\begin{tabular}{|c|c|c|c|c|c|c|c|c|c|c|}
\hline \multicolumn{11}{|c|}{ Fractional Components } \\
\hline \multirow{2}{*}{ Cobbles } & \multicolumn{3}{|c|}{ Gravel } & \multicolumn{4}{|c|}{ Sand } & \multicolumn{3}{|c|}{ Fines } \\
\hline & Coarse & Fine & Total & Coarse & Medium & Fine & Total & Silt & Clay & Total \\
\hline 0.0 & 0.0 & 0.0 & 0.0 & 0.0 & 0.0 & 10.3 & 10.3 & 85.8 & 3.9 & 89.7 \\
\hline
\end{tabular}

\begin{tabular}{|c|c|c|c|c|c|c|c|c|c|}
\hline $\mathrm{D}_{\mathbf{1 0}}$ & $\mathrm{D}_{\mathbf{1 5}}$ & $\mathrm{D}_{\mathbf{2 0}}$ & $\mathrm{D}_{\mathbf{3 0}}$ & $\mathrm{D}_{\mathbf{5 0}}$ & $\mathrm{D}_{\mathbf{6 0}}$ & $\mathrm{D}_{\mathbf{8 0}}$ & $\mathrm{D}_{\mathbf{8 5}}$ & $\mathrm{D}_{\mathbf{9 0}}$ & $\mathrm{D}_{\mathbf{9 5}}$ \\
\hline 0.0229 & 0.0256 & 0.0280 & 0.0325 & 0.0421 & 0.0477 & 0.0629 & 0.0684 & 0.0756 & 0.0869 \\
\hline
\end{tabular}

\begin{tabular}{|c|c|c|}
\hline $\begin{array}{c}\text { Fineness } \\
\text { Modulus }\end{array}$ & $\mathrm{c}_{\mathbf{u}}$ & $\mathrm{c}_{\mathbf{c}}$ \\
\hline 0.00 & 2.09 & 0.97 \\
\hline
\end{tabular}




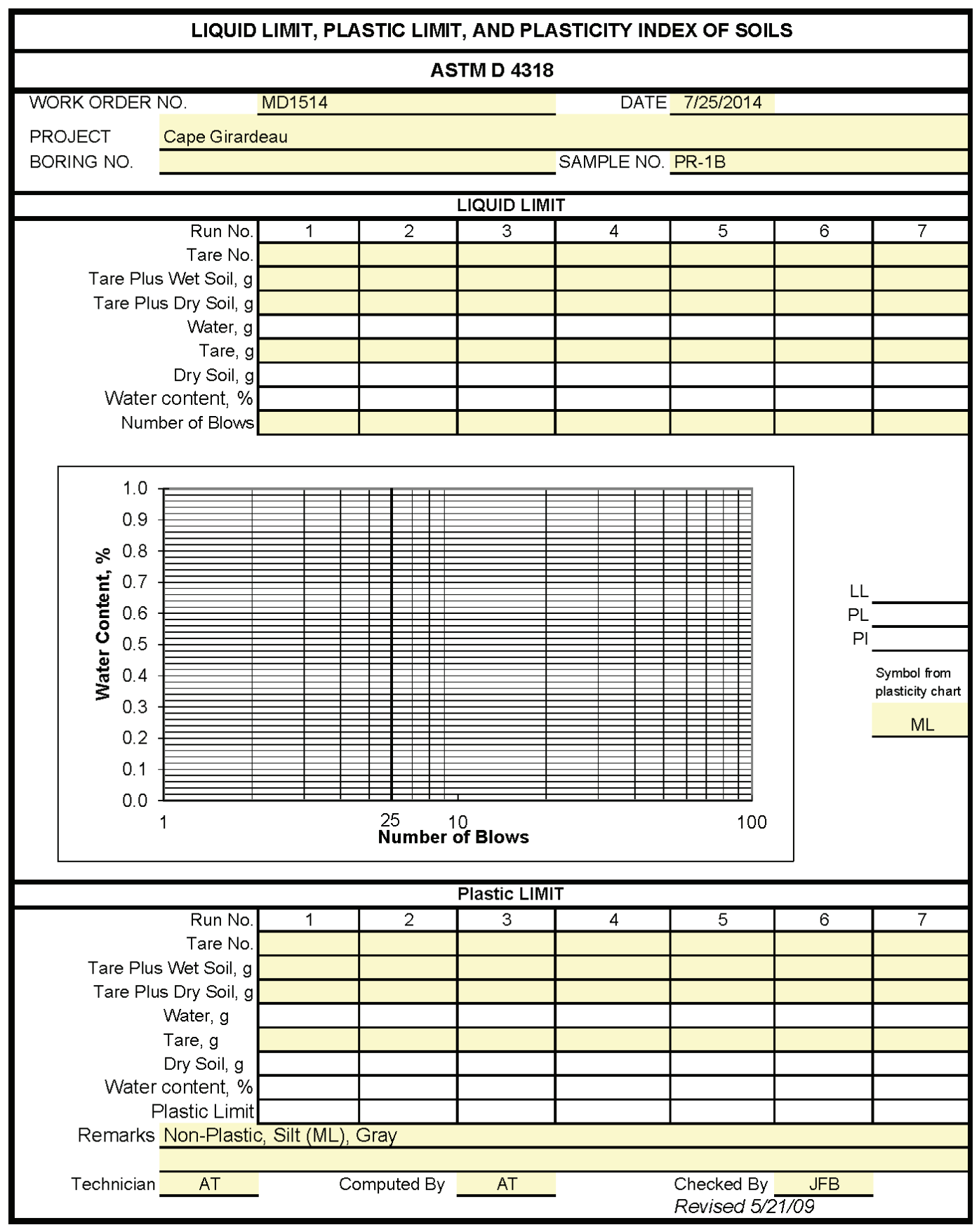




\section{PR-1C:}

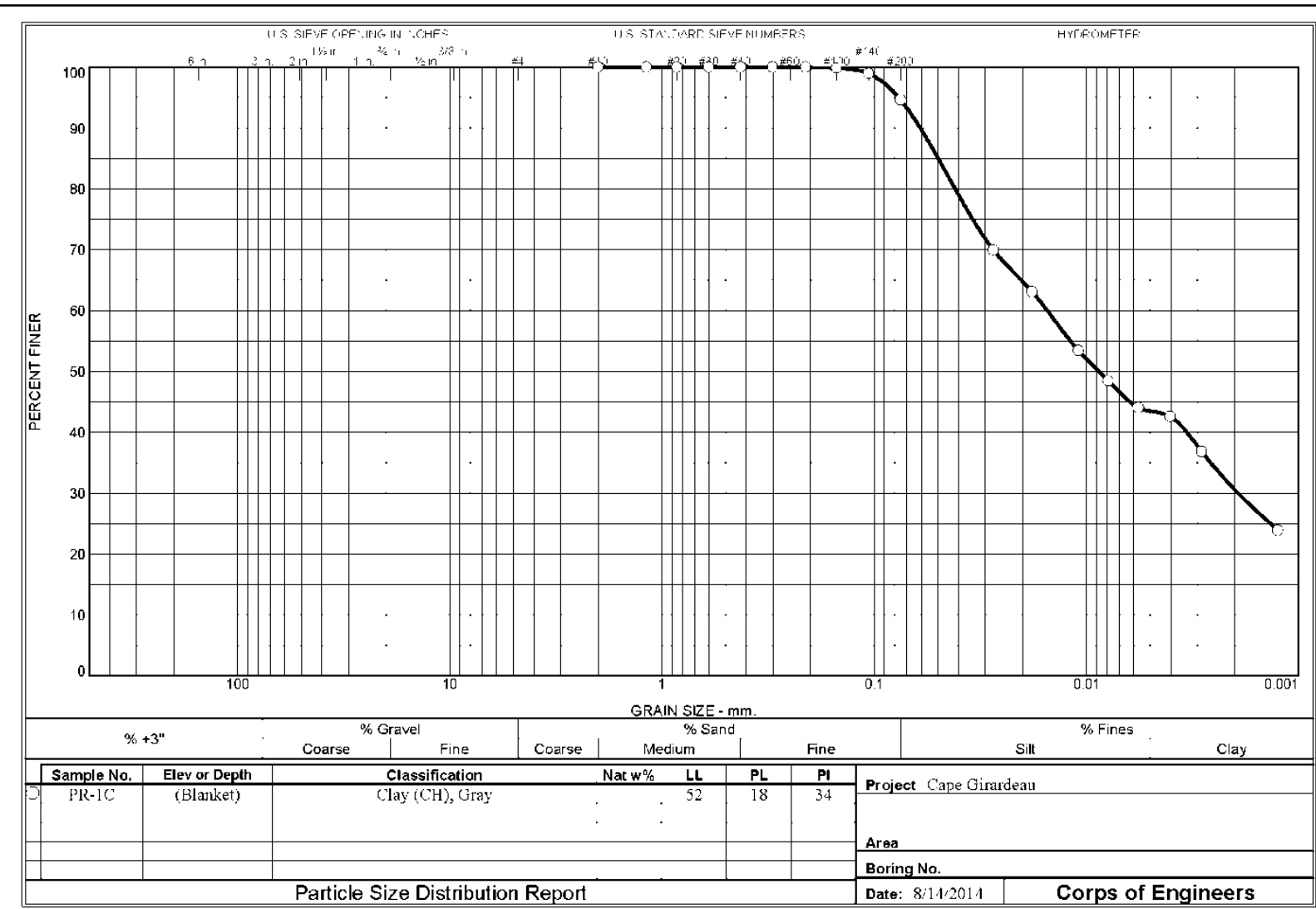

ENG $\underset{1 \text { MAYM } 63}{\text { FORM }} 2087$

Tested By: AT/LDD

Checked By: JFB 
Project: Cape Girardeau

Depth: (Blanket)

Material Description: Clay (CH), Gray

PL: 18

PI: 34

Tested by: AT/LDD

Sample Number: PR-1C

LL: 52

Checked by: JFB

\begin{tabular}{|c|c|c|c|c|c|c|c|c|}
\hline \\
\hline \multicolumn{9}{|c|}{ Sieve Test Data } \\
\hline $\begin{array}{c}\text { Dry } \\
\text { Sample } \\
\text { and Tare } \\
\text { (grams) }\end{array}$ & $\begin{array}{c}\text { Tare } \\
\text { (grams) }\end{array}$ & $\begin{array}{l}\text { Cumulative } \\
\text { Pan } \\
\text { Tare Weight } \\
\text { (grams) }\end{array}$ & \multicolumn{2}{|c|}{$\begin{array}{c}\text { Sieve } \\
\text { Opening } \\
\text { Size }\end{array}$} & $\begin{array}{l}\text { umulative } \\
\text { Weight } \\
\text { Retained } \\
\text { (grams) }\end{array}$ & \multicolumn{2}{|l|}{$\begin{array}{c}\text { Percent } \\
\text { Finer }\end{array}$} & \\
\hline \multirow[t]{10}{*}{57.70} & \multirow[t]{10}{*}{0.00} & \multirow[t]{10}{*}{0.00} & \multicolumn{2}{|c|}{$\# 10$} & 0.00 & \multicolumn{2}{|l|}{100.0} & \\
\hline & & & \multicolumn{2}{|c|}{$\# 16$} & 0.00 & \multicolumn{2}{|l|}{100.0} & \\
\hline & & & \multicolumn{2}{|c|}{$\# 20$} & 0.00 & \multicolumn{2}{|l|}{100.0} & \\
\hline & & & \multicolumn{2}{|c|}{$\# 30$} & 0.00 & \multicolumn{2}{|l|}{100.0} & \\
\hline & & & \multicolumn{2}{|c|}{$\# 40$} & 0.00 & \multicolumn{2}{|l|}{100.0} & \\
\hline & & & \multicolumn{2}{|c|}{$\# 50$} & 0.00 & \multicolumn{2}{|l|}{100.0} & \\
\hline & & & \multicolumn{2}{|c|}{$\# 70$} & 0.00 & \multicolumn{2}{|l|}{100.0} & \\
\hline & & & \multicolumn{2}{|c|}{$\# 100$} & 0.10 & \multicolumn{2}{|l|}{99.8} & \\
\hline & & & \multicolumn{2}{|c|}{$\# 140$} & 0.60 & \multicolumn{2}{|l|}{99.0} & \\
\hline & & & \multicolumn{2}{|c|}{$\# 200$} & 3.10 & \multicolumn{2}{|l|}{94.6} & \\
\hline \multicolumn{9}{|c|}{ Hydrometer Test Data } \\
\hline \multicolumn{9}{|c|}{$\begin{array}{l}\text { Hydrometer test uses material passing \#10 } \\
\text { Percent passing \#10 based upon complete sample }=100.0 \\
\text { Weight of hydrometer sample }=57.7 \\
\text { Automatic temperature correction } \\
\text { Composite correction (fluid density and meniscus height) at } 20 \text { deg. } C=-4 \\
\text { Meniscus correction only }=-0.5 \\
\text { Specific gravity of solids }=2.70 \text { est } \\
\text { Hydrometer type }=151 \mathrm{H} \\
\text { Hydrometer effective depth equation: } L=16.294964-0.2645 \times \mathrm{Rm}\end{array}$} \\
\hline $\begin{array}{l}\text { Elapsed } \\
\text { Time (min.) }\end{array}$ & $\begin{array}{c}\text { Temp. } \\
\text { (deg. C.) }\end{array}$ & $\begin{array}{c}\text { Actual } \\
\text { Reading }\end{array}$ & $\begin{array}{l}\text { Corrected } \\
\text { Reading }\end{array}$ & $\mathrm{K}$ & $\mathrm{Rm}$ & $\begin{array}{c}\text { Eff. } \\
\text { Depth }\end{array}$ & $\begin{array}{c}\text { Diameter } \\
(\mathrm{mm} .)\end{array}$ & $\begin{array}{c}\text { Percent } \\
\text { Finer }\end{array}$ \\
\hline 2.00 & 21.0 & 1.0300 & 1.0254 & 0.0133 & 29.5 & 8.5 & 0.0274 & 69.9 \\
\hline 5.00 & 21.0 & 1.0275 & 1.0229 & 0.0133 & 27.0 & 9.2 & 0.0180 & 63.1 \\
\hline 15.00 & 21.0 & 1.0240 & 1.0194 & 0.0133 & 23.5 & 10.1 & 0.0109 & 53.4 \\
\hline 30.00 & 21.0 & 1.0222 & 1.0176 & 0.0133 & 21.7 & 10.6 & 0.0079 & 48.5 \\
\hline 60.00 & 21.0 & 1.0206 & 1.0160 & 0.0133 & 20.1 & 11.0 & 0.0057 & 44.1 \\
\hline 120.00 & 21.5 & 1.0200 & 1.0155 & 0.0132 & 19.5 & 11.1 & 0.0040 & 42.6 \\
\hline 250.00 & 21.5 & 1.0179 & 1.0134 & 0.0132 & 17.4 & 11.7 & 0.0029 & 36.8 \\
\hline 1440.00 & 21.5 & 1.0132 & 1.0087 & 0.0132 & 12.7 & 12.9 & 0.0013 & 23.9 \\
\hline
\end{tabular}




\begin{tabular}{|c|c|c|c|c|c|c|c|c|c|c|c|c|}
\hline \multicolumn{13}{|c|}{ Fractional Components } \\
\hline \multirow{2}{*}{ Cobbles } & \multicolumn{3}{|c|}{ Gravel } & \multicolumn{6}{|c|}{ Sand } & \multicolumn{3}{|c|}{ Fines } \\
\hline & Coarse & Fine & Total & \multicolumn{2}{|c|}{ Coarse } & \multicolumn{2}{|c|}{ Medium } & Fine & Total & \multicolumn{3}{|r|}{ Total } \\
\hline 0.0 & 0.0 & 0.0 & 0.0 & & & 0 & & 5.4 & 5.4 & 51.1 & 43.5 & 94.6 \\
\hline$D_{10}$ & $D_{15}$ & $D_{2}$ & & & $D_{5}$ & & & & $D_{80}$ & $D_{85}$ & $\mathrm{D}_{90}$ & $\mathrm{D}_{95}$ \\
\hline & & & 0.0 & & 0.0 & & & & 0.0415 & 0.0499 & 0.0606 & 0.0766 \\
\hline
\end{tabular}

Fineness

Modulus

0.00 


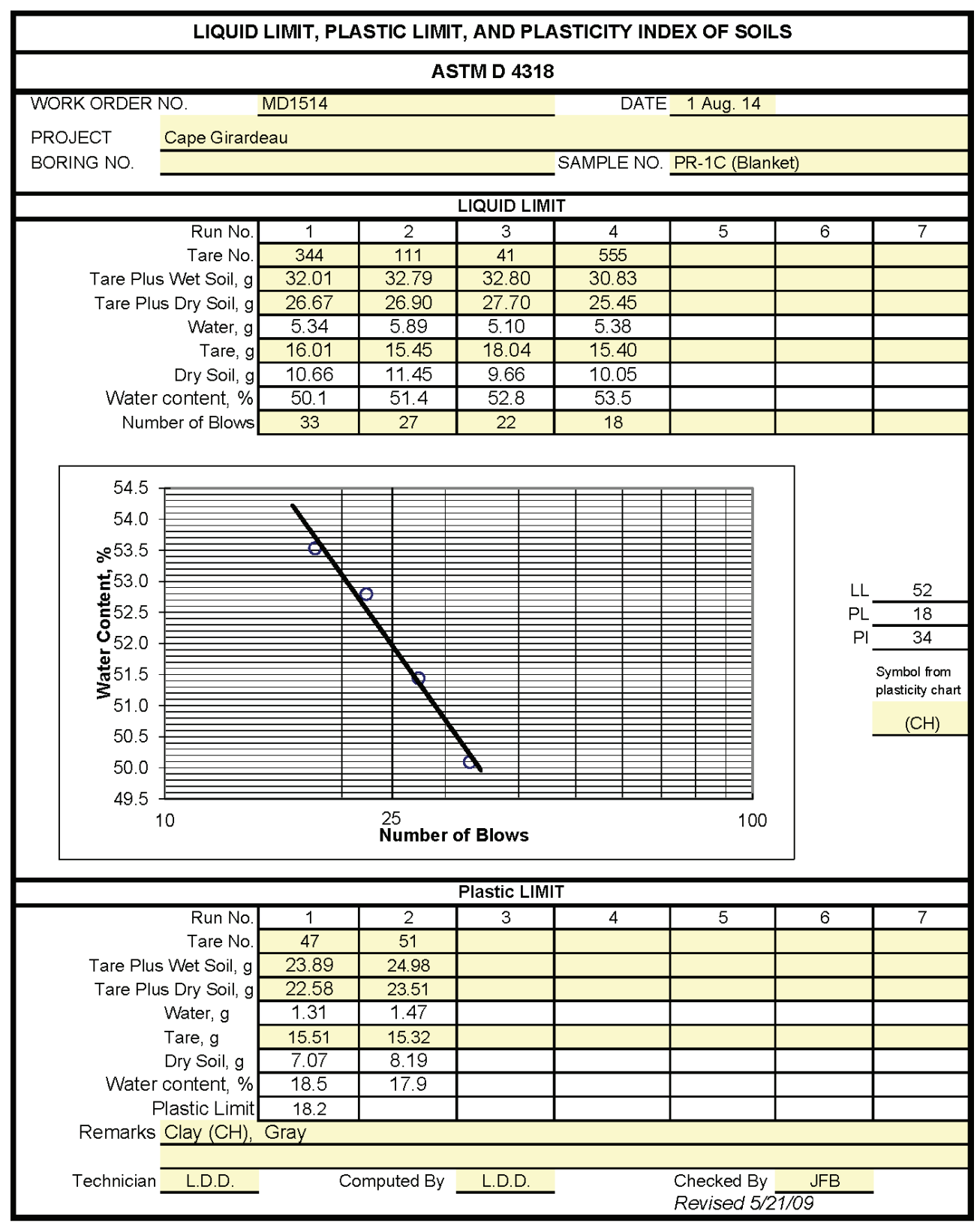




\section{PR-2A:}

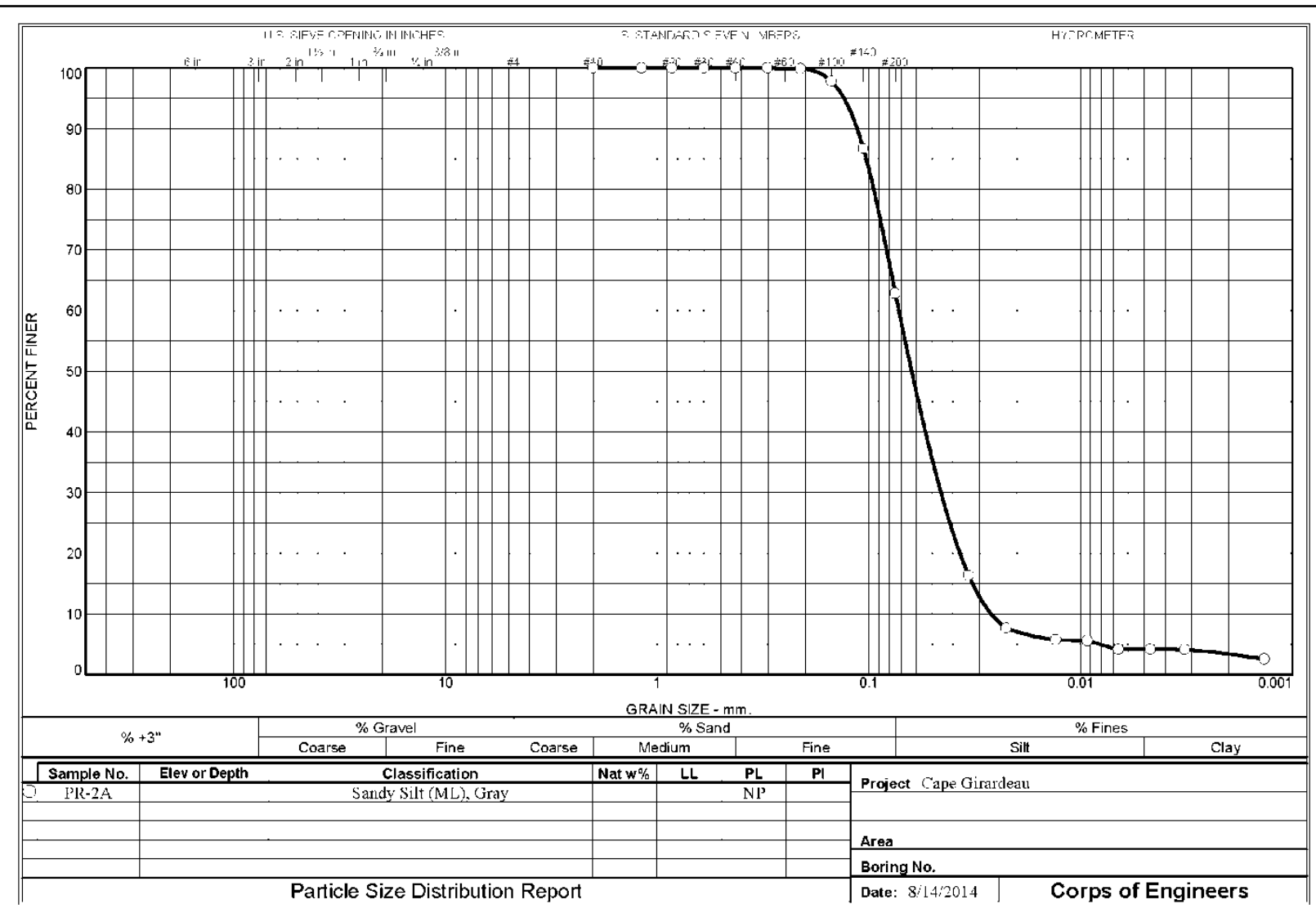

ENG 1 MORM 2087

Tested By: AT/LDD Checked By: JFB 
Project: Cape Girardeau

Sample Number: PR-2A

Material Description: Sandy Silt (ML), Gray

PL: NP

Tested by: AT/LDD

Checked by: JFB

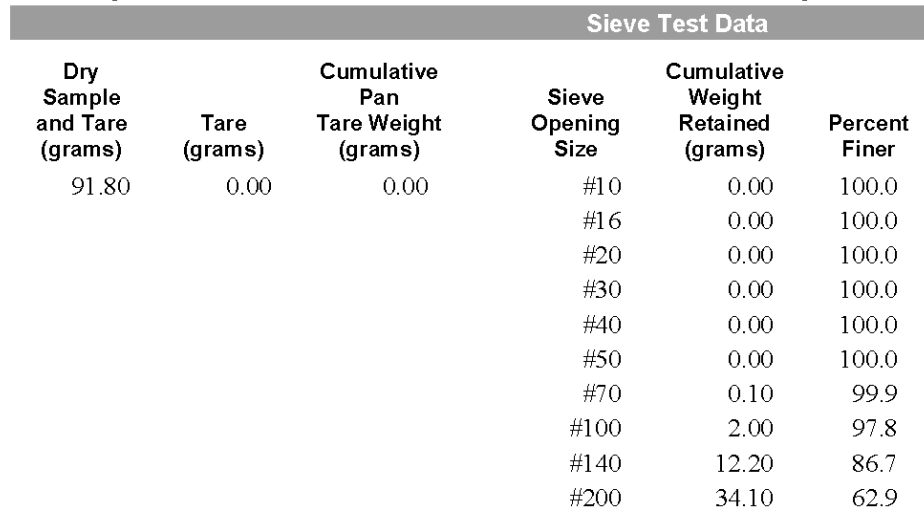

Hydrometer test uses material passing \#10

Percent passing $\# 10$ based upon complete sample $=100.0$

Weight of hydrometer sample $=91.8$

Automatic temperature correction

Composite correction (fluid density and meniscus height) at $20 \mathrm{deg} . \mathrm{C}=-4.7$

Meniscus correction only $=-0.5$

Specific gravity of solids $=2.67$ est

Hydrometer type $=151 \mathrm{H}$

Hydrometer effective depth equation: $L=16.294964-0.2645 \times \mathrm{Rm}$

$\begin{array}{ccccccccc}\begin{array}{c}\text { Elapsed } \\ \text { Time (min.) }\end{array} & \begin{array}{c}\text { Temp. } \\ \text { (deg. C.) }\end{array} & \begin{array}{c}\text { Actual } \\ \text { Reading }\end{array} & \begin{array}{c}\text { Corrected } \\ \text { Reading }\end{array} & \mathbf{K} & \mathbf{R m} & \begin{array}{c}\text { Eff. } \\ \text { Depth }\end{array} & \begin{array}{c}\text { Diameter } \\ (\mathbf{m m} .)\end{array} & \begin{array}{c}\text { Percent } \\ \text { Finer }\end{array} \\ 2.00 & 21.0 & 1.0140 & 1.0094 & 0.0134 & 13.5 & 12.7 & 0.0338 & 16.4 \\ 5.00 & 21.0 & 1.0090 & 1.0044 & 0.0134 & 8.5 & 14.0 & 0.0225 & 7.7 \\ 15.00 & 21.0 & 1.0079 & 1.0033 & 0.0134 & 7.4 & 14.3 & 0.0131 & 5.8 \\ 30.00 & 21.0 & 1.0078 & 1.0032 & 0.0134 & 7.3 & 14.4 & 0.0093 & 5.6 \\ 60.00 & 21.0 & 1.0070 & 1.0024 & 0.0134 & 6.5 & 14.6 & 0.0066 & 4.2 \\ 120.00 & 21.0 & 1.0070 & 1.0024 & 0.0134 & 6.5 & 14.6 & 0.0047 & 4.2 \\ 250.00 & 21.5 & 1.0069 & 1.0024 & 0.0133 & 6.4 & 14.6 & 0.0032 & 4.1 \\ 1440.00 & 21.5 & 1.0060 & 1.0015 & 0.0133 & 5.5 & 14.8 & 0.0014 & 2.6\end{array}$




\begin{tabular}{|c|c|c|c|c|c|c|c|c|c|c|}
\hline \multicolumn{11}{|c|}{ Fractional Components } \\
\hline \multirow{2}{*}{ Cobbles } & \multicolumn{3}{|c|}{ Gravel } & \multicolumn{4}{|c|}{ Sand } & \multicolumn{3}{|c|}{ Fines } \\
\hline & Coarse & Fine & Total & Coarse & Medium & Fine & Total & Silt & Clay & Total \\
\hline 0.0 & 0.0 & 0.0 & 0.0 & 0.0 & 0.0 & 37.1 & 37.1 & 58.7 & 4.2 & 62.9 \\
\hline
\end{tabular}

\begin{tabular}{|c|c|c|c|c|c|c|c|c|c|}
\hline $\mathbf{D}_{\mathbf{1 0}}$ & $\mathbf{D}_{\mathbf{1 5}}$ & $\mathbf{D}_{\mathbf{2 0}}$ & $\mathbf{D}_{\mathbf{3 0}}$ & $\mathbf{D}_{\mathbf{5 0}}$ & $\mathbf{D}_{\mathbf{6 0}}$ & $\mathbf{D}_{\mathbf{8 0}}$ & $\mathrm{D}_{\mathbf{8 5}}$ & $\mathrm{D}_{\mathbf{9 0}}$ & $\mathrm{D}_{\mathbf{9 5}}$ \\
\hline 0.0264 & 0.0324 & 0.0372 & 0.0457 & 0.0628 & 0.0722 & 0.0949 & 0.1028 & 0.1134 & 0.1308 \\
\hline
\end{tabular}

\begin{tabular}{|c|c|c|}
\hline $\begin{array}{c}\text { Fineness } \\
\text { Modulus }\end{array}$ & $\mathrm{c}_{\mathbf{u}}$ & $\mathrm{c}_{\mathrm{c}}$ \\
\hline 0.02 & 2.73 & 1.09 \\
\hline
\end{tabular}




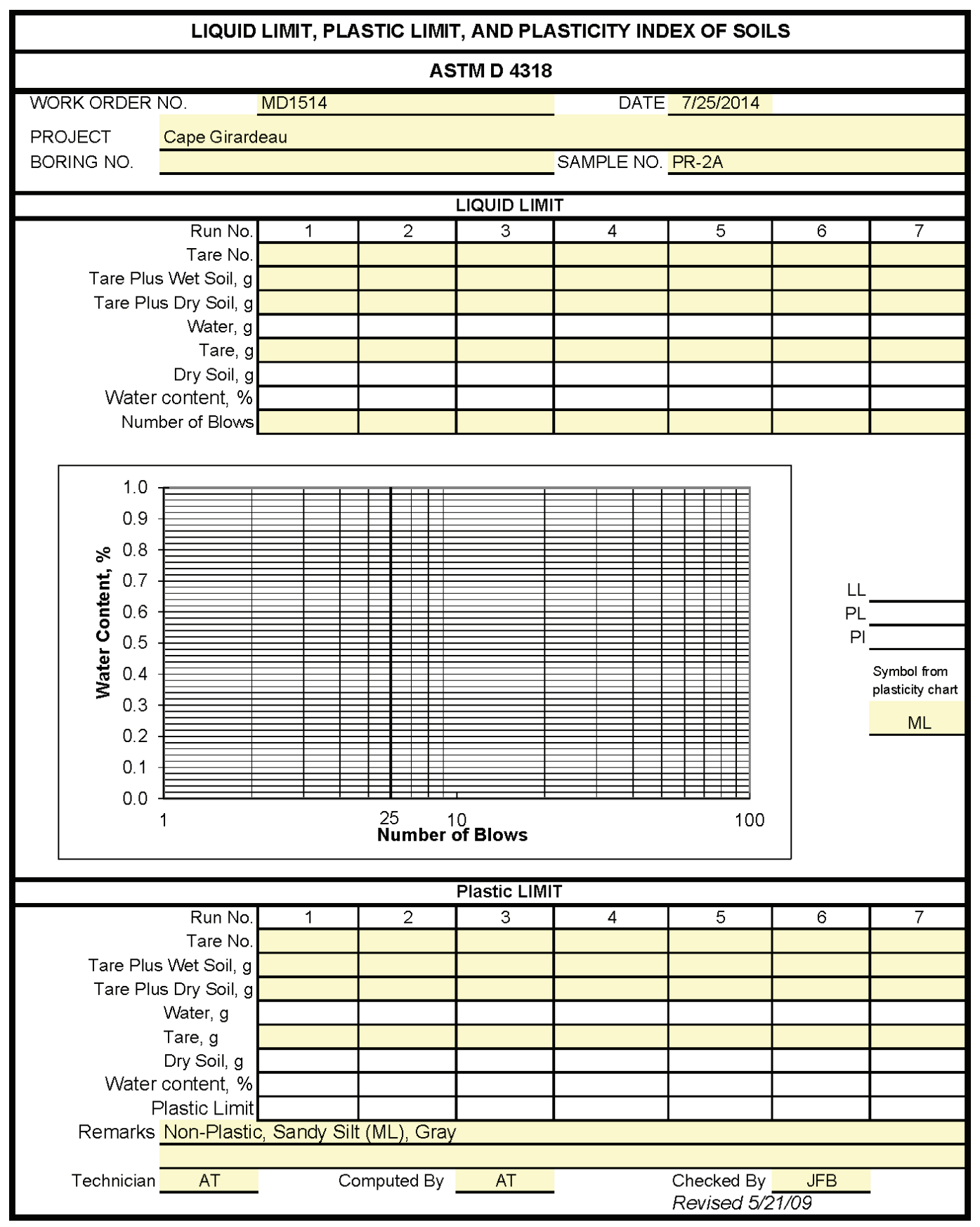




\section{PR-2B:}

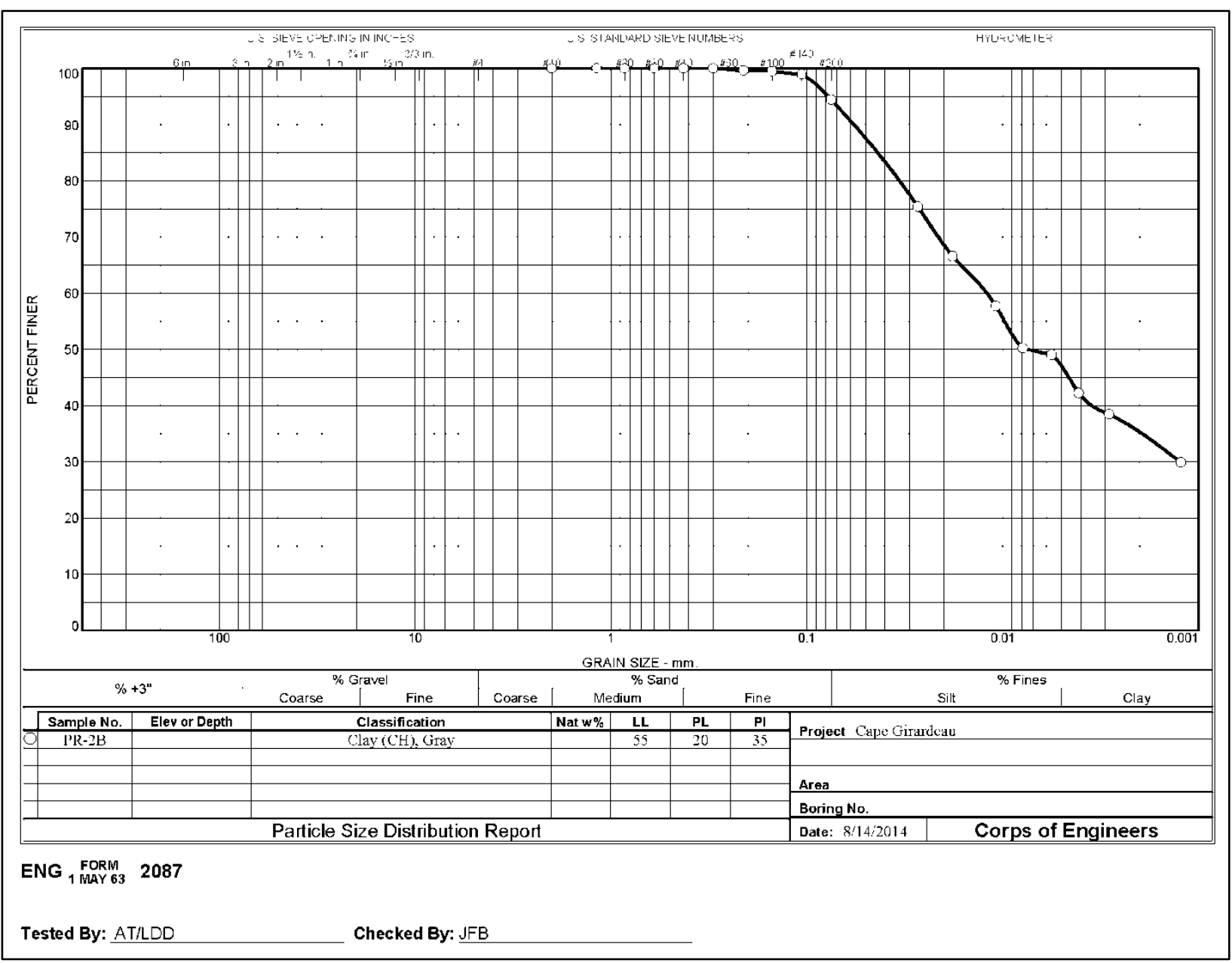


Project: Cape Girardeau

Sample Number: PR-2B

Material Description: Clay $(\mathrm{CH})$, Gray

PL: 20

LL: 55

PI: 35

Tested by: AT/LDD

Checked by: JFB

\begin{tabular}{|c|c|c|c|c|c|c|c|c|}
\hline & & & & Sieve Te & est Data & & & \\
\hline $\begin{array}{c}\text { Dry } \\
\text { Sample } \\
\text { and Tare } \\
\text { (grams) }\end{array}$ & $\begin{array}{c}\text { Tare } \\
\text { (grams) }\end{array}$ & $\begin{array}{c}\text { Cumulative } \\
\text { Pan } \\
\text { Tare Weight } \\
\text { (grams) }\end{array}$ & $\begin{array}{l}\mathrm{Si} \\
\text { Ope } \\
\mathrm{S}\end{array}$ & & $\begin{array}{l}\text { umulative } \\
\text { Weight } \\
\text { Retained } \\
\text { (grams) }\end{array}$ & $\begin{array}{c}\text { Percent } \\
\text { Finer }\end{array}$ & & \\
\hline 55.70 & 0.00 & 0.00 & & 10 & 0.00 & 100.0 & & \\
\hline & & & & 16 & 0.00 & 100.0 & & \\
\hline & & & & 20 & 0.00 & 100.0 & & \\
\hline & & & & 30 & 0.00 & 100.0 & & \\
\hline & & & & 40 & 0.00 & 100.0 & & \\
\hline & & & & 50 & 0.00 & 100.0 & & \\
\hline & & & & 70 & 0.20 & 99.6 & & \\
\hline & & & & 00 & 0.30 & 99.5 & & \\
\hline & & & & 40 & 0.60 & 98.9 & & \\
\hline & & & & 00 & 3.10 & 94.4 & & \\
\hline & & & & rometer & r Test Dat & & & \\
\hline $\begin{array}{l}\text { Hydrometer te } \\
\text { Percent passin } \\
\text { Weight of hydr } \\
\text { Automatic tem } \\
\text { Composite } \\
\text { Meniscus corr } \\
\text { Specific gravit } \\
\text { Hydrometer ty } \\
\text { Hydrometer }\end{array}$ & $\begin{array}{l}\text { t uses mate } \\
\text { g\#10 based } \\
\text { meter samp } \\
\text { erature cor } \\
\text { orrection (fl } \\
\text { ction only = } \\
\text { of solids }= \\
e=151 \mathrm{H} \\
\text { effective dep }\end{array}$ & $\begin{array}{l}\text { ial passing } \# 1 \\
\text { upon complete } \\
\text { le }=55.7 \\
\text { ection } \\
\text { id density and } \\
-0.5 \\
.70 \\
\text { th equation: } L\end{array}$ & $\begin{array}{l}0 \\
\text { e sample }=1 \\
\text { meniscus } \\
=16.29496\end{array}$ & $\begin{array}{l}\text { ght) at } 2( \\
0.2645 x\end{array}$ & $\begin{array}{l}0 \mathrm{deg} . \mathrm{C}= \\
\times \mathrm{Rm}\end{array}$ & -4.7 & & \\
\hline $\begin{array}{c}\text { Elapsed } \\
\text { Time (min.) }\end{array}$ & $\begin{array}{l}\text { Temp. } \\
\text { (deg. C.) }\end{array}$ & $\begin{array}{l}\text { Actual } \\
\text { Reading }\end{array}$ & $\begin{array}{l}\text { Corrected } \\
\text { Reading }\end{array}$ & $\mathrm{K}$ & $\mathrm{Rm}$ & $\begin{array}{l}\text { Eff. } \\
\text { Depth }\end{array}$ & $\begin{array}{c}\text { Diameter } \\
(\mathrm{mm} .)\end{array}$ & $\begin{array}{l}\text { Percent } \\
\text { Finer }\end{array}$ \\
\hline 2.00 & 20.5 & 1.0311 & 1.0264 & 0.0134 & 30.6 & 8.2 & 0.0271 & 75.4 \\
\hline 5.00 & 20.5 & 1.0280 & 1.0233 & 0.0134 & 27.5 & 9.0 & 0.0179 & 66.6 \\
\hline 15.00 & 20.5 & 1.0249 & 1.0202 & 0.0134 & 24.4 & 9.8 & 0.0108 & 57.7 \\
\hline 30.00 & 21.0 & 1.0222 & 1.0176 & 0.0133 & 21.7 & 10.6 & 0.0079 & 50.2 \\
\hline 60.00 & 21.0 & 1.0218 & 1.0172 & 0.0133 & 21.3 & 10.7 & 0.0056 & 49.1 \\
\hline 120.00 & 21.0 & 1.0194 & 1.0148 & 0.0133 & 18.9 & 11.3 & 0.0041 & 42.2 \\
\hline 250.00 & 21.5 & 1.0180 & 1.0135 & 0.0132 & 17.5 & 11.7 & 0.0029 & 38.4 \\
\hline 1440.00 & 21.5 & 1.0150 & 1.0105 & 0.0132 & 14.5 & 12.5 & 0.0012 & 29.9 \\
\hline
\end{tabular}




\begin{tabular}{|}
\hline \multicolumn{10}{|c|}{ Fractional Components } \\
\begin{tabular}{|c|c|c|c|c|c|c|c|c|c|c|}
\hline \multirow{2}{*}{ Cobbles } & \multicolumn{9}{c|}{ Sand } & Fravel \\
& Coarse & Fine & Total & Coarse & Medium & Fine & Total & Silt & Clay & Total \\
\hline 0.0 & 0.0 & 0.0 & 0.0 & 0.0 & 0.0 & 5.6 & 5.6 & 47.3 & 47.1 & 94.4 \\
\hline
\end{tabular}
\end{tabular}

\begin{tabular}{|c|c|c|c|c|c|c|c|c|c|}
\hline $\mathrm{D}_{\mathbf{1 0}}$ & $\mathrm{D}_{\mathbf{1 5}}$ & $\mathrm{D}_{\mathbf{2 0}}$ & $\mathrm{D}_{\mathbf{3 0}}$ & $\mathrm{D}_{\mathbf{5 0}}$ & $\mathrm{D}_{\mathbf{6 0}}$ & $\mathrm{D}_{\mathbf{8 0}}$ & $\mathrm{D}_{\mathbf{8 5}}$ & $\mathrm{D}_{\mathbf{9 0}}$ & $\mathrm{D}_{\mathbf{9 5}}$ \\
\hline & & & 0.0012 & 0.0074 & 0.0120 & 0.0336 & 0.0434 & 0.0574 & 0.0777 \\
\hline
\end{tabular}

Fineness

Modulus

0.01 


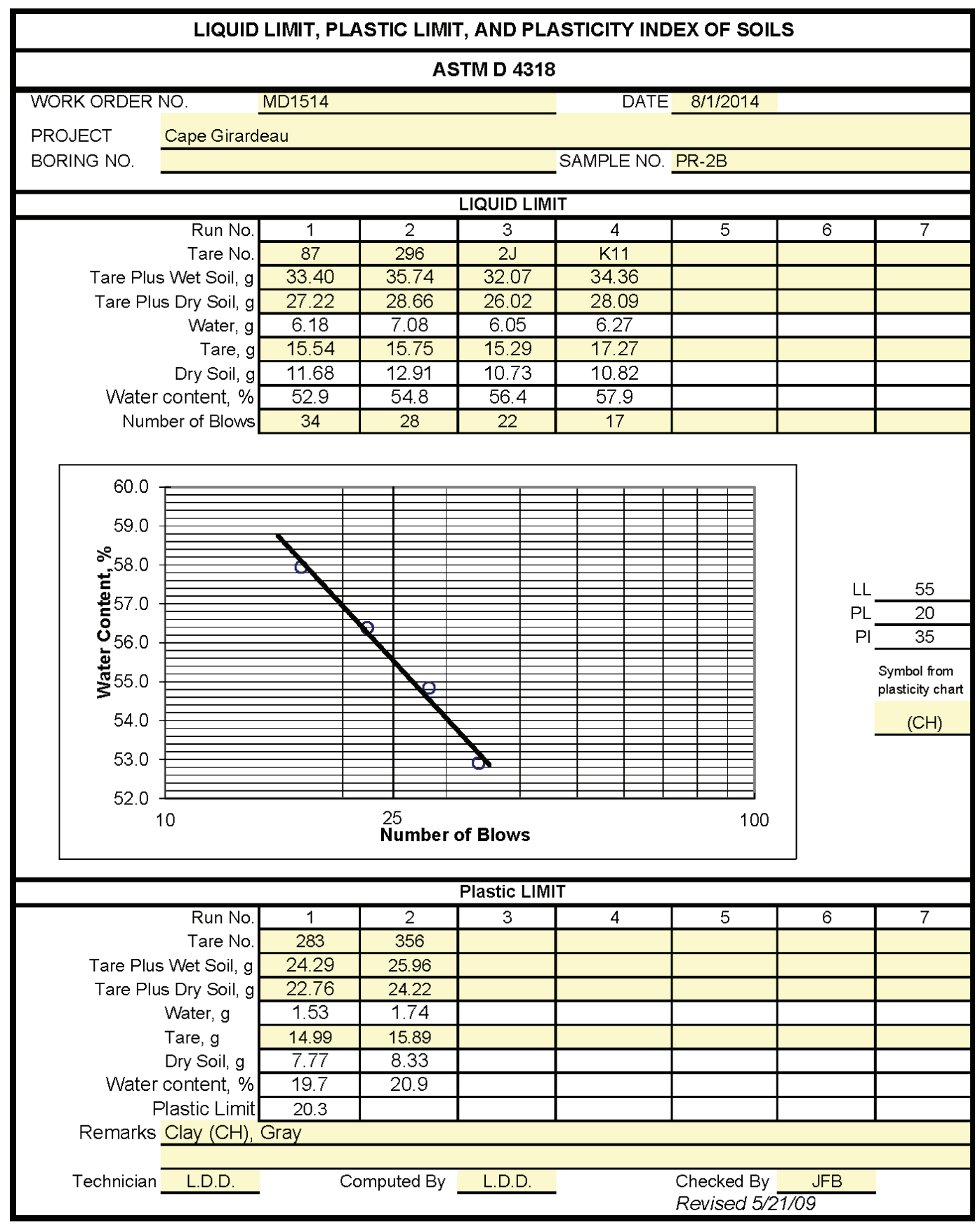




\section{PR-4A:}

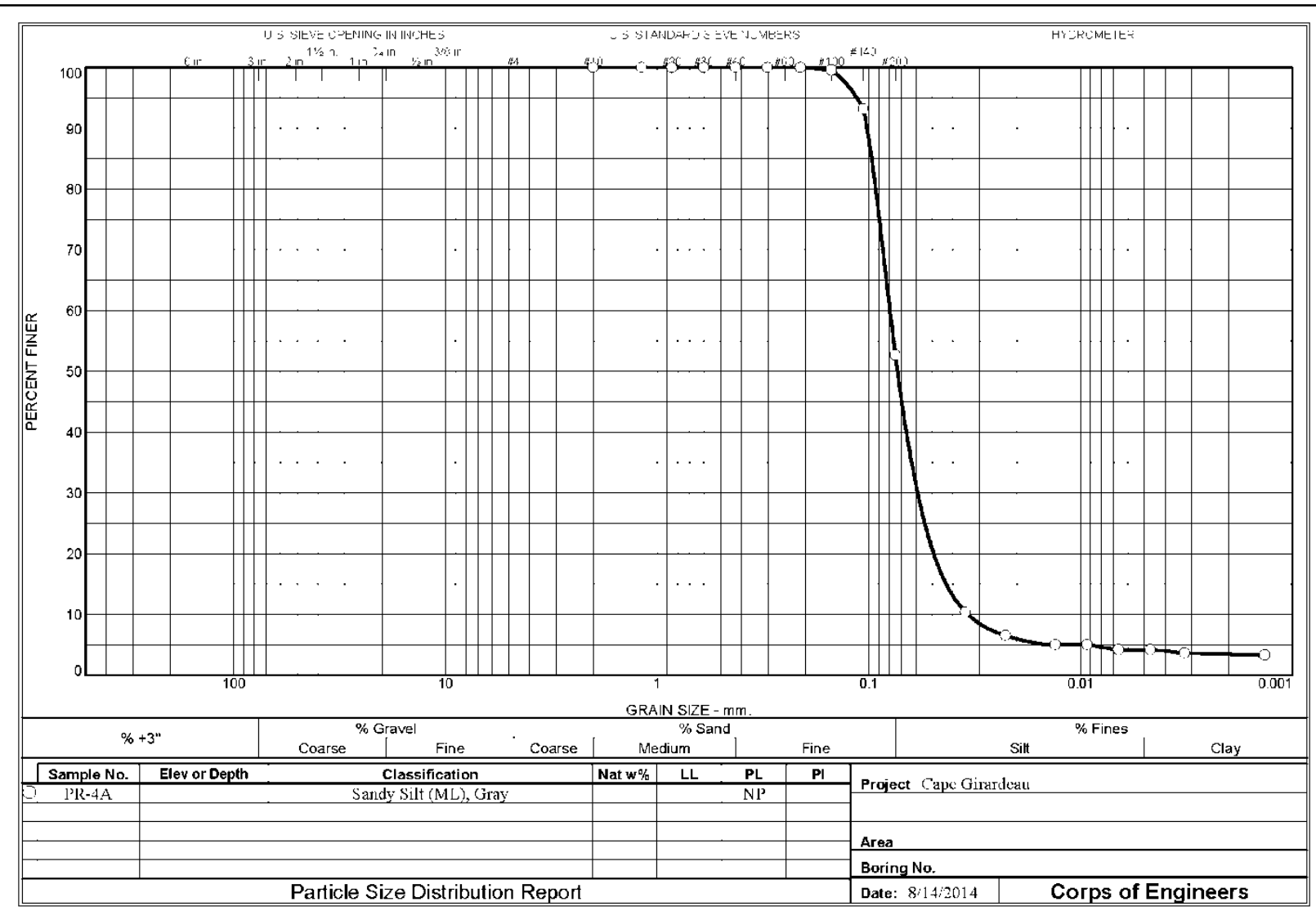

ENG 1 FORM 2087

Tested By: AT/LDD

Checked By: JFB 
Project: Cape Girardeau

Sample Number: PR-4A

Material Description: Sandy Silt (ML), Gray

PL: NP

Tested by: AT/LDD

Checked by: JFB

\begin{tabular}{|c|c|c|c|c|c|}
\hline \multirow[b]{2}{*}{$\begin{array}{l}\text { Dry } \\
\text { Sample } \\
\text { and Tare } \\
\text { (grams) }\end{array}$} & \multirow[b]{2}{*}{$\begin{array}{c}\text { Tare } \\
\text { (grams) }\end{array}$} & \multicolumn{4}{|c|}{ Sieve Test Data } \\
\hline & & $\begin{array}{c}\text { Cumulative } \\
\text { Pan } \\
\text { Tare Weight } \\
\text { (grams) }\end{array}$ & $\begin{array}{c}\text { Sieve } \\
\text { Opening } \\
\text { Size }\end{array}$ & $\begin{array}{c}\text { Cumulative } \\
\text { Weight } \\
\text { Retained } \\
\text { (grams) }\end{array}$ & $\begin{array}{l}\text { Percent } \\
\text { Finer }\end{array}$ \\
\hline \multirow[t]{10}{*}{95.50} & 0.00 & 0.00 & $\# 10$ & 0.00 & 100.0 \\
\hline & & & $\# 16$ & 0.00 & 100.0 \\
\hline & & & $\# 20$ & 0.00 & 100.0 \\
\hline & & & $\# 30$ & 0.00 & 100.0 \\
\hline & & & $\# 40$ & 0.00 & 100.0 \\
\hline & & & $\# 50$ & 0.00 & 100.0 \\
\hline & & & $\# 70$ & 0.00 & 100.0 \\
\hline & & & $\# 100$ & 0.40 & 99.6 \\
\hline & & & $\# 140$ & 6.50 & 93.2 \\
\hline & & & $\# 200$ & 45.20 & 52.7 \\
\hline
\end{tabular}

Hydrometer test uses material passing $\# 10$

\section{Hydrometer Test Data}

Percent passing $\# 10$ based upon complete sample $=100.0$

Weight of hydrometer sample $=95.5$

Automatic temperature correction

Composite correction (fluid density and meniscus height) at $20 \mathrm{deg} . \mathrm{C}=-4.7$

Meniscus correction only $=-0.5$

Specific gravity of solids $=2.67$ est

Hydrometer type $=151 \mathrm{H}$

Hydrometer effective depth equation: $L=16.294964-0.2645 \times \mathbf{R m}$

$\begin{array}{ccccccccc}\begin{array}{c}\text { Elapsed } \\ \text { Time (min.) }\end{array} & \begin{array}{c}\text { Temp. } \\ \text { (deg. C.) }\end{array} & \begin{array}{c}\text { Actual } \\ \text { Reading }\end{array} & \begin{array}{c}\text { Corrected } \\ \text { Reading }\end{array} & \mathbf{K} & \mathbf{R m} & \begin{array}{c}\text { Eff. } \\ \text { Depth }\end{array} & \begin{array}{c}\text { Diameter } \\ \text { (mm.) }\end{array} & \begin{array}{c}\text { Percent } \\ \text { Finer }\end{array} \\ 2.00 & 21.0 & 1.0108 & 1.0062 & 0.0134 & 10.3 & 13.6 & 0.0349 & 10.4 \\ 5.00 & 21.0 & 1.0085 & 1.0039 & 0.0134 & 8.0 & 14.2 & 0.0226 & 6.5 \\ 15.00 & 21.0 & 1.0076 & 1.0030 & 0.0134 & 7.1 & 14.4 & 0.0131 & 5.0 \\ 30.00 & 21.0 & 1.0076 & 1.0030 & 0.0134 & 7.1 & 14.4 & 0.0093 & 5.0 \\ 60.00 & 21.0 & 1.0071 & 1.0025 & 0.0134 & 6.6 & 14.5 & 0.0066 & 4.2 \\ 120.00 & 21.0 & 1.0071 & 1.0025 & 0.0134 & 6.6 & 14.5 & 0.0047 & 4.2 \\ 250.00 & 21.5 & 1.0067 & 1.0022 & 0.0133 & 6.2 & 14.7 & 0.0032 & 3.6 \\ 1440.00 & 21.5 & 1.0065 & 1.0020 & 0.0133 & 6.0 & 14.7 & 0.0013 & 3.3\end{array}$




\begin{tabular}{|c|c|c|c|c|c|c|c|c|c|c|}
\hline & & & & Fract & ral Com & ents & & & & \\
\hline \multirow{2}{*}{ Cobbles } & \multicolumn{3}{|c|}{ Gravel } & \multicolumn{4}{|c|}{ Sand } & \multicolumn{3}{|c|}{ Fines } \\
\hline & Coarse & Fine & Total & Coarse & Medium & Fine & Total & Silt & Clay & Total \\
\hline 0.0 & 0.0 & 0.0 & 0.0 & 0.0 & 0.0 & 47.3 & 47.3 & 48.5 & 4.2 & 52.7 \\
\hline
\end{tabular}

\begin{tabular}{|c|c|c|c|c|c|c|c|c|c|}
\hline $\mathbf{D}_{\mathbf{1 0}}$ & $\mathbf{D}_{\mathbf{1 5}}$ & $\mathbf{D}_{\mathbf{2 0}}$ & $\mathbf{D}_{\mathbf{3 0}}$ & $\mathbf{D}_{\mathbf{5 0}}$ & $\mathbf{D}_{\mathbf{6 0}}$ & $\mathbf{D}_{\mathbf{8 0}}$ & $\mathbf{D}_{\mathbf{8 5}}$ & $\mathbf{D}_{\mathbf{9 0}}$ & $\mathbf{D}_{\mathbf{9 5}}$ \\
\hline 0.0340 & 0.0432 & 0.0495 & 0.0589 & 0.0733 & 0.0795 & 0.0929 & 0.0970 & 0.1020 & 0.1138 \\
\hline
\end{tabular}

\begin{tabular}{|c|c|c|}
\hline $\begin{array}{c}\text { Fineness } \\
\text { Modulus }\end{array}$ & $\mathrm{c}_{\mathrm{u}}$ & $\mathrm{c}_{\mathrm{c}}$ \\
\hline 0.00 & 2.34 & 1.28 \\
\hline
\end{tabular}




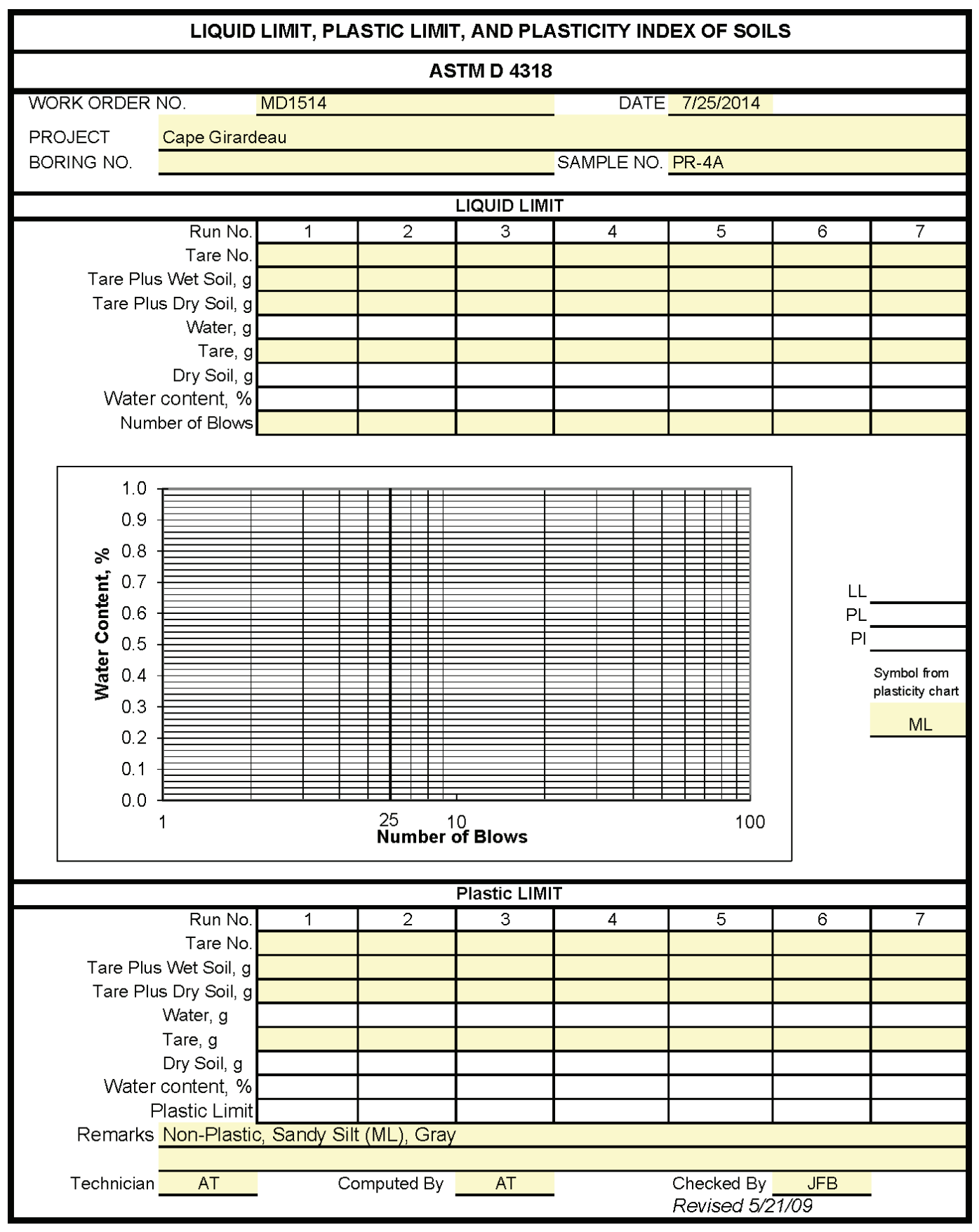




\section{PR-4B:}

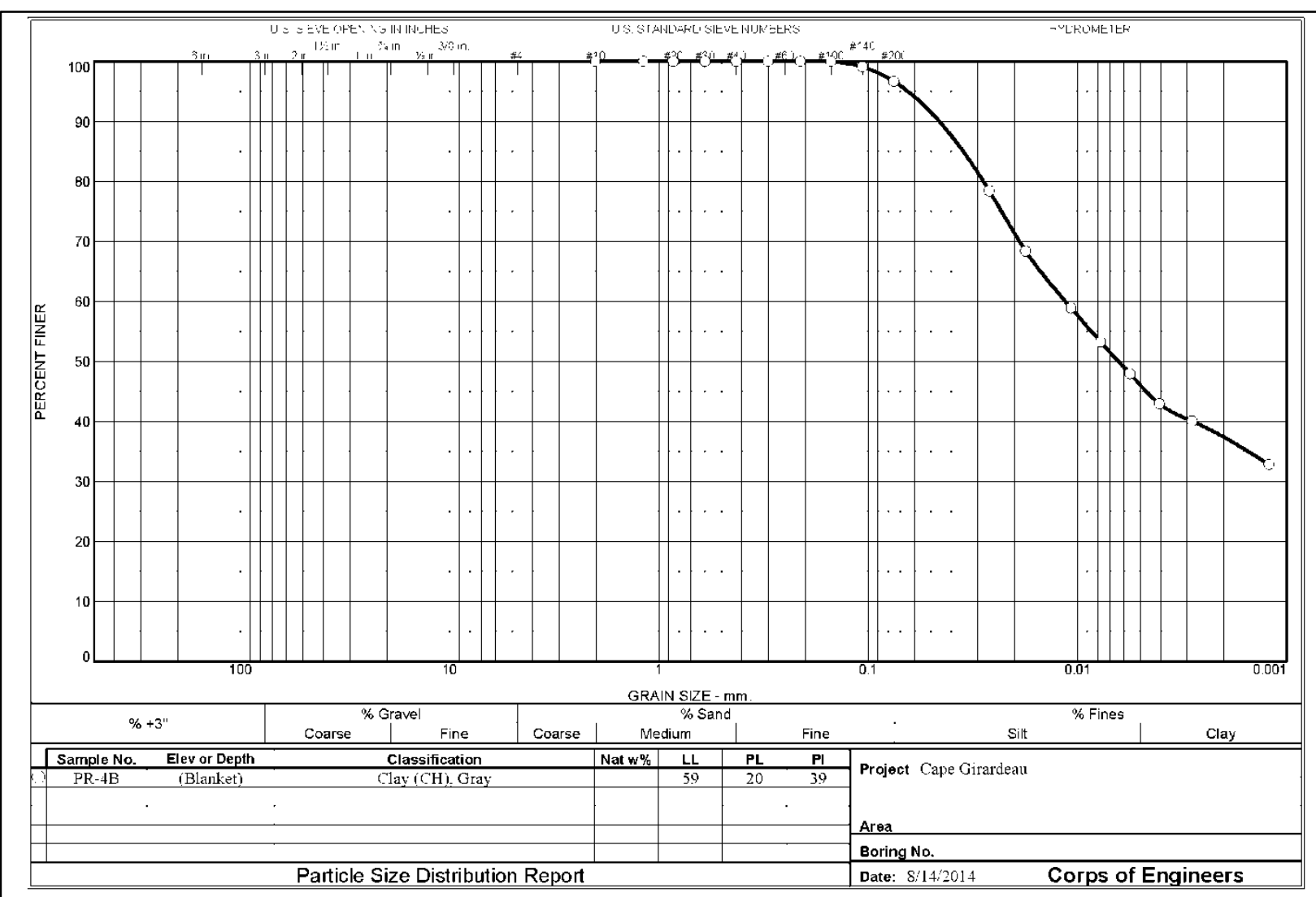

ENG $\begin{gathered}\text { FORM } \\ \text { MAY } 63\end{gathered} 2087$ 
Project: Cape Girardeau

Depth: (Blanket)

Material Description: Clay $(\mathrm{CH})$, Gray

PL: 20

PI: 39

Tested by: AT/LDD

Sample Number: PR-4B

LL: 59

Checked by: JFB

\begin{tabular}{|c|c|c|c|c|c|c|c|c|}
\hline (2) - & & & & Sieve Te & est Data & 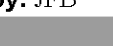 & & \\
\hline $\begin{array}{c}\text { Dry } \\
\text { Sample } \\
\text { and Tare } \\
\text { (grams) }\end{array}$ & $\begin{array}{c}\text { Tare } \\
\text { (grams) }\end{array}$ & $\begin{array}{c}\text { Cumulative } \\
\text { Pan } \\
\text { Tare Weight } \\
\text { (grams) }\end{array}$ & $\begin{array}{r}\mathrm{Si} \\
\text { Ope } \\
\mathrm{Si}\end{array}$ & & $\begin{array}{l}\text { Cumulative } \\
\text { Weight } \\
\text { Retained } \\
\text { (grams) }\end{array}$ & $\begin{array}{l}\text { Percent } \\
\text { Finer }\end{array}$ & & \\
\hline 57.00 & 0.00 & 0.00 & & $\neq 10$ & 0.00 & 100.0 & & \\
\hline & & & & $\$ 16$ & 0.00 & 100.0 & & \\
\hline & & & & $\$ 20$ & 0.00 & 100.0 & & \\
\hline & & & & $\$ 30$ & 0.00 & 100.0 & & \\
\hline & & & & $\$ 40$ & 0.00 & 100.0 & & \\
\hline & & & & 450 & 0.00 & 100.0 & & \\
\hline & & & & $\$ 70$ & 0.00 & 100.0 & & \\
\hline & & & & 100 & 0.00 & 100.0 & & \\
\hline & & & & 140 & 0.50 & 99.1 & & \\
\hline & & & & 200 & 1.90 & 96.7 & & \\
\hline & & & & Jromete & er Test Dat & & & \\
\hline $\begin{array}{l}\text { Hydrometer tes } \\
\text { Percent passin } \\
\text { Weight of hydr } \\
\text { Automatic tem } \\
\text { Composite } \\
\text { Meniscus corr } \\
\text { Specific gravit } \\
\text { Hydrometer ty } \\
\text { Hydrometer }\end{array}$ & $\begin{array}{l}\text { t uses mate } \\
\mathrm{g} \# 10 \text { based } \\
\text { ometer samp } \\
\text { verature cor } \\
\text { orrection (fll } \\
\text { ction only = } \\
\text { of solids = } \\
\text { e }=151 \mathrm{H} \\
\text { effective dep }\end{array}$ & $\begin{array}{l}\text { ial passing } \# 1 \\
\text { upon complete } \\
\text { le }=57.0 \\
\text { ection } \\
\text { id density and } \\
-0.5 \\
.70 \\
\text { th equation: } L\end{array}$ & $\begin{array}{l}\text { e sample }=1 \\
\text { meniscus } \mathrm{h} \\
=16.294964\end{array}$ & $\begin{array}{l}0.0 \\
\text { ight) at } 2 \\
0.2645\end{array}$ & $\begin{array}{l}20 \mathrm{deg} . \mathrm{C}= \\
\times \mathrm{Rm}\end{array}$ & & & \\
\hline $\begin{array}{c}\text { Elapsed } \\
\text { Time (min.) }\end{array}$ & $\begin{array}{l}\text { Temp. } \\
\text { (deg. C.) }\end{array}$ & $\begin{array}{c}\text { Actual } \\
\text { Reading }\end{array}$ & $\begin{array}{l}\text { Corrected } \\
\text { Reading }\end{array}$ & $\mathrm{K}$ & $\mathrm{Rm}$ & $\begin{array}{c}\text { Eff. } \\
\text { Depth }\end{array}$ & $\begin{array}{c}\text { Diameter } \\
(\mathrm{mm} .)\end{array}$ & $\begin{array}{c}\text { Percent } \\
\text { Finer }\end{array}$ \\
\hline 2.00 & 20.5 & 1.0328 & 1.0281 & 0.0134 & 32.3 & 7.8 & 0.0263 & 78.4 \\
\hline 5.00 & 20.5 & 1.0292 & 1.0245 & 0.0134 & 28.7 & 8.7 & 0.0176 & 68.4 \\
\hline 15.00 & 20.5 & 1.0258 & 1.0211 & 0.0134 & 25.3 & 9.6 & 0.0107 & 58.9 \\
\hline 30.00 & 21.0 & 1.0237 & 1.0191 & 0.0133 & 23.2 & 10.2 & 0.0077 & 53.2 \\
\hline 60.00 & 21.0 & 1.0218 & 1.0172 & 0.0133 & 21.3 & 10.7 & 0.0056 & 47.9 \\
\hline 120.00 & 21.0 & 1.0200 & 1.0154 & 0.0133 & 19.5 & 11.1 & 0.0040 & 42.9 \\
\hline 250.00 & 21.5 & 1.0189 & 1.0144 & 0.0132 & 18.4 & 11.4 & 0.0028 & 40.1 \\
\hline 1440.00 & 21.5 & 1.0163 & 1.0118 & 0.0132 & 15.8 & 12.1 & 0.0012 & 32.8 \\
\hline
\end{tabular}




\begin{tabular}{|c|c|c|c|c|c|c|c|c|c|c|}
\hline \multicolumn{11}{|c|}{ Fractional Components } \\
\hline \multirow{2}{*}{ Cobbles } & \multicolumn{3}{|c|}{ Gravel } & \multicolumn{4}{|c|}{ Sand } & \multicolumn{3}{|c|}{ Fines } \\
\hline & Coarse & Fine & Total & Coarse & Medium & Fine & Total & Silt & Clay & Total \\
\hline 0.0 & 0.0 & 0.0 & 0.0 & 0.0 & 0.0 & 3.3 & 3.3 & 50.6 & 46.1 & 96.7 \\
\hline
\end{tabular}

\begin{tabular}{|c|c|c|c|c|c|c|c|c|c|}
\hline $\mathrm{D}_{\mathbf{1 0}}$ & $\mathrm{D}_{\mathbf{1 5}}$ & $\mathrm{D}_{\mathbf{2 0}}$ & $\mathrm{D}_{\mathbf{3 0}}$ & $\mathrm{D}_{\mathbf{5 0}}$ & $\mathrm{D}_{\mathbf{6 0}}$ & $\mathrm{D}_{\mathbf{8 0}}$ & $\mathrm{D}_{\mathbf{8 5}}$ & $\mathrm{D}_{\mathbf{9 0}}$ & $\mathrm{D}_{\mathbf{9 5}}$ \\
\hline & & & & 0.0063 & 0.0114 & 0.0281 & 0.0351 & 0.0456 & 0.0643 \\
\hline
\end{tabular}

Fineness

Modulus

0.00 


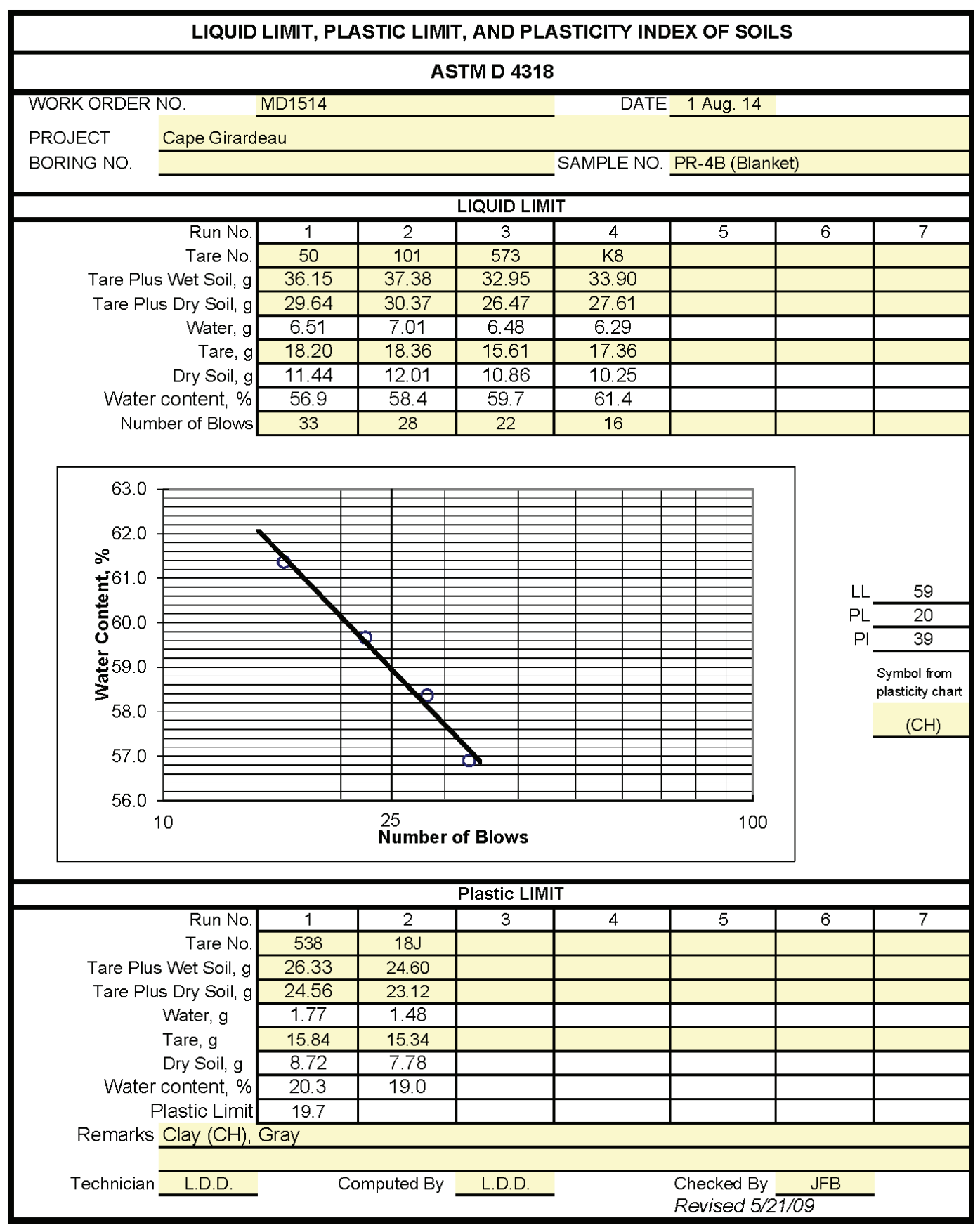


PR-7:

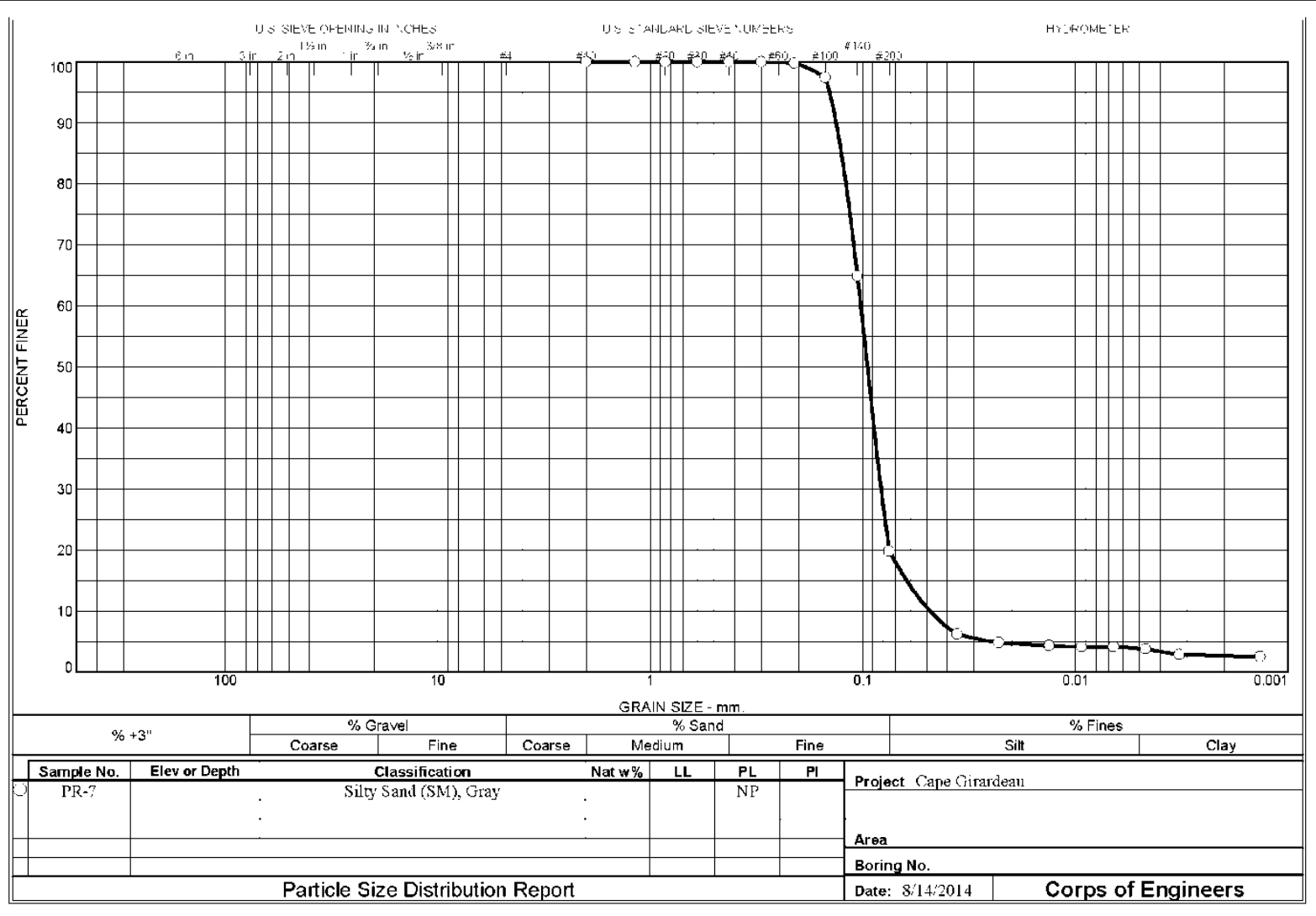

ENG $1 \underset{\text { MAY } 63}{\text { FORM }} 2087$

Tested By: AT/LDD

Checked By: JFB 
Project: Cape Girardeau

Sample Number: PR-7

Material Description: Silty Sand (SM), Gray

PL: NP

Tested by: AT/LDD

Checked by: JFB

\begin{tabular}{|c|c|c|c|c|c|}
\hline \multicolumn{6}{|c|}{ Sieve Test Data } \\
\hline $\begin{array}{c}\text { Dry } \\
\text { Sample } \\
\text { and Tare } \\
\text { (grams) }\end{array}$ & $\begin{array}{c}\text { Tare } \\
\text { (grams) }\end{array}$ & $\begin{array}{l}\text { Cumulative } \\
\text { Pan } \\
\text { Tare Weight } \\
\text { (grams) }\end{array}$ & $\begin{array}{c}\text { Sieve } \\
\text { Opening } \\
\text { Size }\end{array}$ & $\begin{array}{c}\text { Cumulative } \\
\text { Weight } \\
\text { Retained } \\
\text { (grams) }\end{array}$ & $\begin{array}{l}\text { Percent } \\
\text { Finer }\end{array}$ \\
\hline \multirow[t]{10}{*}{93.40} & 0.00 & 0.00 & $\# 10$ & 0.00 & 100.0 \\
\hline & & & $\# 16$ & 0.00 & 100.0 \\
\hline & & & $\# 20$ & 0.00 & 100.0 \\
\hline & & & $\# 30$ & 0.00 & 100.0 \\
\hline & & & $\# 40$ & 0.00 & 100.0 \\
\hline & & & $\# 50$ & 0.00 & 100.0 \\
\hline & & & $\# 70$ & 0.20 & 99.8 \\
\hline & & & $\# 100$ & 2.40 & 97.4 \\
\hline & & & $\# 140$ & 32.80 & 64.9 \\
\hline & & & $\# 200$ & 74.90 & 19.8 \\
\hline
\end{tabular}

Hydrometer test uses material passing $\# 10$

Hydrometer Test Data

Percent passing \#10 based upon complete sample $=100.0$

Weight of hydrometer sample $=93.4$

Automatic temperature correction

Composite correction (fluid density and meniscus height) at $\mathbf{2 0}$ deg. $C=-4.7$

Meniscus correction only $=-0.5$

Specific gravity of solids $=2.67$ est

Hydrometer type $=151 \mathrm{H}$

Hydrometer effective depth equation: $L=16.294964-0.2645 \times$ Rm

$\begin{array}{ccccccccc}\begin{array}{c}\text { Elapsed } \\ \text { Time (min.) }\end{array} & \begin{array}{c}\text { Temp. } \\ \text { (deg. C.) }\end{array} & \begin{array}{c}\text { Actual } \\ \text { Reading }\end{array} & \begin{array}{c}\text { Corrected } \\ \text { Reading }\end{array} & \mathbf{K} & \mathbf{R m} & \begin{array}{c}\text { Eff. } \\ \text { Depth }\end{array} & \begin{array}{c}\text { Diameter } \\ \text { (mm.) }\end{array} & \begin{array}{c}\text { Percent } \\ \text { Finer }\end{array} \\ 2.00 & 20.5 & 1.0083 & 1.0036 & 0.0135 & 7.8 & 14.2 & 0.0360 & 6.2 \\ 5.00 & 20.5 & 1.0075 & 1.0028 & 0.0135 & 7.0 & 14.4 & 0.0229 & 4.9 \\ 15.00 & 20.5 & 1.0072 & 1.0025 & 0.0135 & 6.7 & 14.5 & 0.0133 & 4.3 \\ 30.00 & 21.0 & 1.0070 & 1.0024 & 0.0134 & 6.5 & 14.6 & 0.0093 & 4.1 \\ 60.00 & 21.0 & 1.0070 & 1.0024 & 0.0134 & 6.5 & 14.6 & 0.0066 & 4.1 \\ 120.00 & 21.0 & 1.0068 & 1.0022 & 0.0134 & 6.3 & 14.6 & 0.0047 & 3.8 \\ 250.00 & 21.5 & 1.0062 & 1.0017 & 0.0133 & 5.7 & 14.8 & 0.0032 & 2.9 \\ 1440.00 & 21.5 & 1.0060 & 1.0015 & 0.0133 & 5.5 & 14.8 & 0.0014 & 2.5\end{array}$




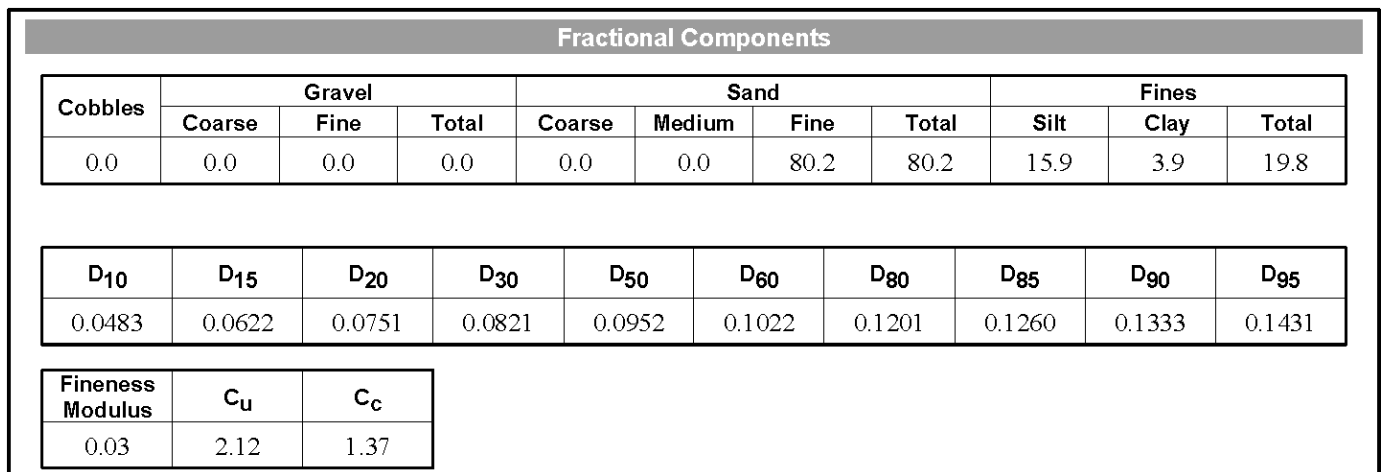




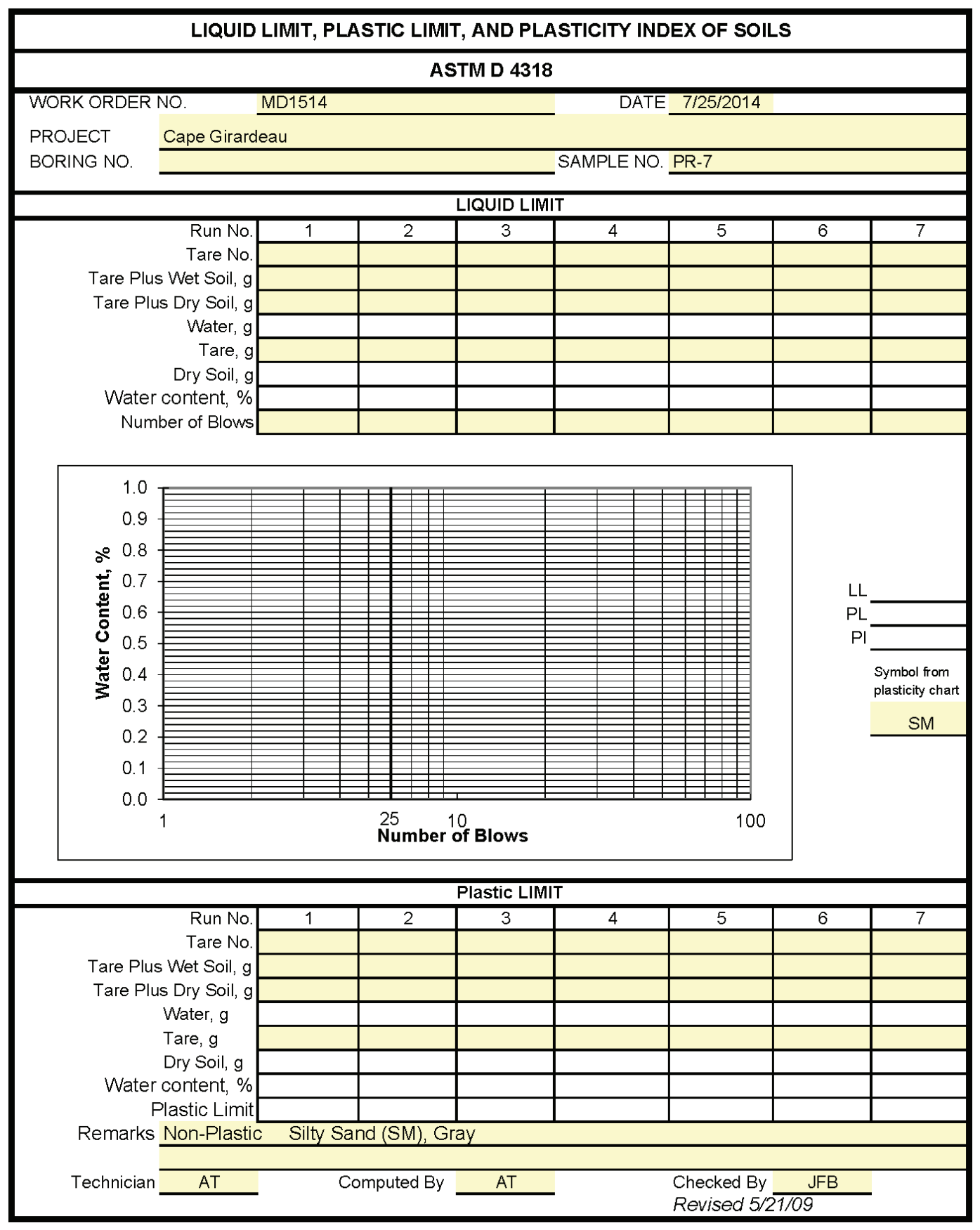




\section{PR-8:}

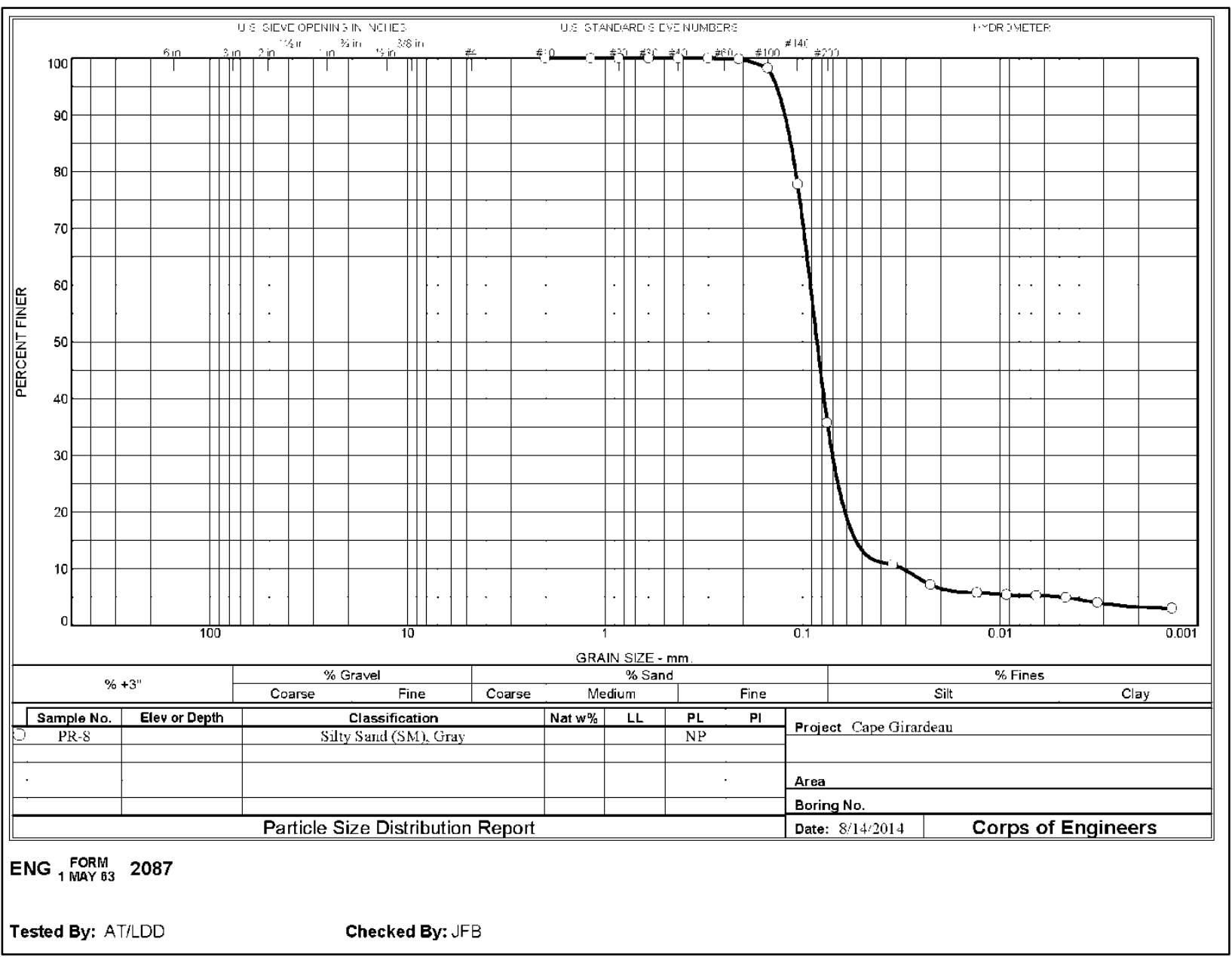


Project: Cape Girardeau

Sample Number: PR-8

Material Description: Silty Sand (SM), Gray

PL: NP

Tested by: AT/LDD

Checked by: JFB

\begin{tabular}{|c|c|c|c|c|c|}
\hline \multicolumn{6}{|c|}{ Sieve Test Data } \\
\hline $\begin{array}{c}\text { Dry } \\
\text { Sample } \\
\text { and Tare } \\
\text { (grams) }\end{array}$ & $\begin{array}{c}\text { Tare } \\
\text { (grams) }\end{array}$ & $\begin{array}{c}\text { Cumulative } \\
\text { Pan } \\
\text { Tare Weight } \\
\text { (grams) }\end{array}$ & $\begin{array}{c}\text { Sieve } \\
\text { Opening } \\
\text { Size }\end{array}$ & $\begin{array}{c}\text { Cumulative } \\
\text { Weight } \\
\text { Retained } \\
\text { (grams) }\end{array}$ & $\begin{array}{c}\text { Percent } \\
\text { Finer }\end{array}$ \\
\hline \multirow[t]{10}{*}{93.70} & 0.00 & 0.00 & $\# 10$ & 0.00 & 100.0 \\
\hline & & & $\# 16$ & 0.00 & 100.0 \\
\hline & & & $\# 20$ & 0.00 & 100.0 \\
\hline & & & $\# 30$ & 0.00 & 100.0 \\
\hline & & & $\# 40$ & 0.00 & 100.0 \\
\hline & & & $\# 50$ & 0.00 & 100.0 \\
\hline & & & $\# 70$ & 0.10 & 99.9 \\
\hline & & & $\# 100$ & 1.60 & 98.3 \\
\hline & & & $\# 140$ & 20.80 & 77.8 \\
\hline & & & $\# 200$ & 60.20 & 35.8 \\
\hline
\end{tabular}

Hydrometer test uses material passing \#10

Percent passing $\# 10$ based upon complete sample $=100.0$

Weight of hydrometer sample $=93.7$

Automatic temperature correction

Composite correction (fluid density and meniscus height) at $\mathbf{2 0} \mathrm{deg} . \mathrm{C}=-4.7$

Meniscus correction only $=-0.5$

Specific gravity of solids $=2.67$ est

Hydrometer type $=151 \mathrm{H}$

Hydrometer effective depth equation: $L=16.294964-0.2645 \times \mathbf{R m}$

$\begin{array}{ccccccccc}\begin{array}{c}\text { Elapsed } \\ \text { Time (min.) }\end{array} & \begin{array}{c}\text { Temp. } \\ \text { (deg. C.) }\end{array} & \begin{array}{c}\text { Actual } \\ \text { Reading }\end{array} & \begin{array}{c}\text { Corrected } \\ \text { Reading }\end{array} & \mathbf{K} & \mathbf{R m} & \begin{array}{c}\text { Eff. } \\ \text { Depth }\end{array} & \begin{array}{c}\text { Diameter } \\ \text { (mm.) }\end{array} & \begin{array}{c}\text { Percent } \\ \text { Finer }\end{array} \\ 2.00 & 21.0 & 1.0109 & 1.0063 & 0.0134 & 10.4 & 13.5 & 0.0349 & 10.8 \\ 5.00 & 21.0 & 1.0088 & 1.0042 & 0.0134 & 8.3 & 14.1 & 0.0225 & 7.2 \\ 15.00 & 21.0 & 1.0080 & 1.0034 & 0.0134 & 7.5 & 14.3 & 0.0131 & 5.8 \\ 30.00 & 21.0 & 1.0078 & 1.0032 & 0.0134 & 7.3 & 14.4 & 0.0093 & 5.5 \\ 60.00 & 21.0 & 1.0077 & 1.0031 & 0.0134 & 7.2 & 14.4 & 0.0066 & 5.3 \\ 120.00 & 21.0 & 1.0075 & 1.0029 & 0.0134 & 7.0 & 14.4 & 0.0046 & 5.0 \\ 250.00 & 21.5 & 1.0069 & 1.0024 & 0.0133 & 6.4 & 14.6 & 0.0032 & 4.1 \\ 1440.00 & 21.5 & 1.0063 & 1.0018 & 0.0133 & 5.8 & 14.8 & 0.0013 & 3.0\end{array}$




\begin{tabular}{|c|c|c|c|c|c|c|c|c|c|c|c|}
\hline \multicolumn{12}{|c|}{ Fractional Components } \\
\hline \multirow{2}{*}{ Cobbles } & \multicolumn{3}{|c|}{ Gravel } & \multicolumn{5}{|c|}{ Sand } & \multicolumn{3}{|c|}{ Fines } \\
\hline & Coarse & Fine & Total & Coarse & & & Fine & Total & Silt & Clay & Total \\
\hline 0.0 & 0.0 & 0.0 & 0.0 & 0.0 & 0 & & 64.2 & 64.2 & 30.7 & 5.1 & 35.8 \\
\hline$D_{10}$ & $\mathrm{D}_{15}$ & $\mathrm{D}_{20}$ & $\mathrm{D}_{3 \mathrm{C}}$ & D & & $D_{60}$ & & $D_{80}$ & $D_{85}$ & $\mathrm{D}_{90}$ & D95 \\
\hline 0.0309 & 0.0539 & 0.0611 & 0.07 & 0.0 & & 0.091 & & 0.1083 & 0.1146 & 0.1228 & 0.1351 \\
\hline $\begin{array}{l}\text { Fineness } \\
\text { Modulus }\end{array}$ & $\mathrm{c}_{\mathrm{u}}$ & $\mathrm{c}_{\mathrm{c}}$ & & & & & & & & & \\
\hline 0.02 & 2.95 & 1.76 & & & & & & & & & \\
\hline
\end{tabular}




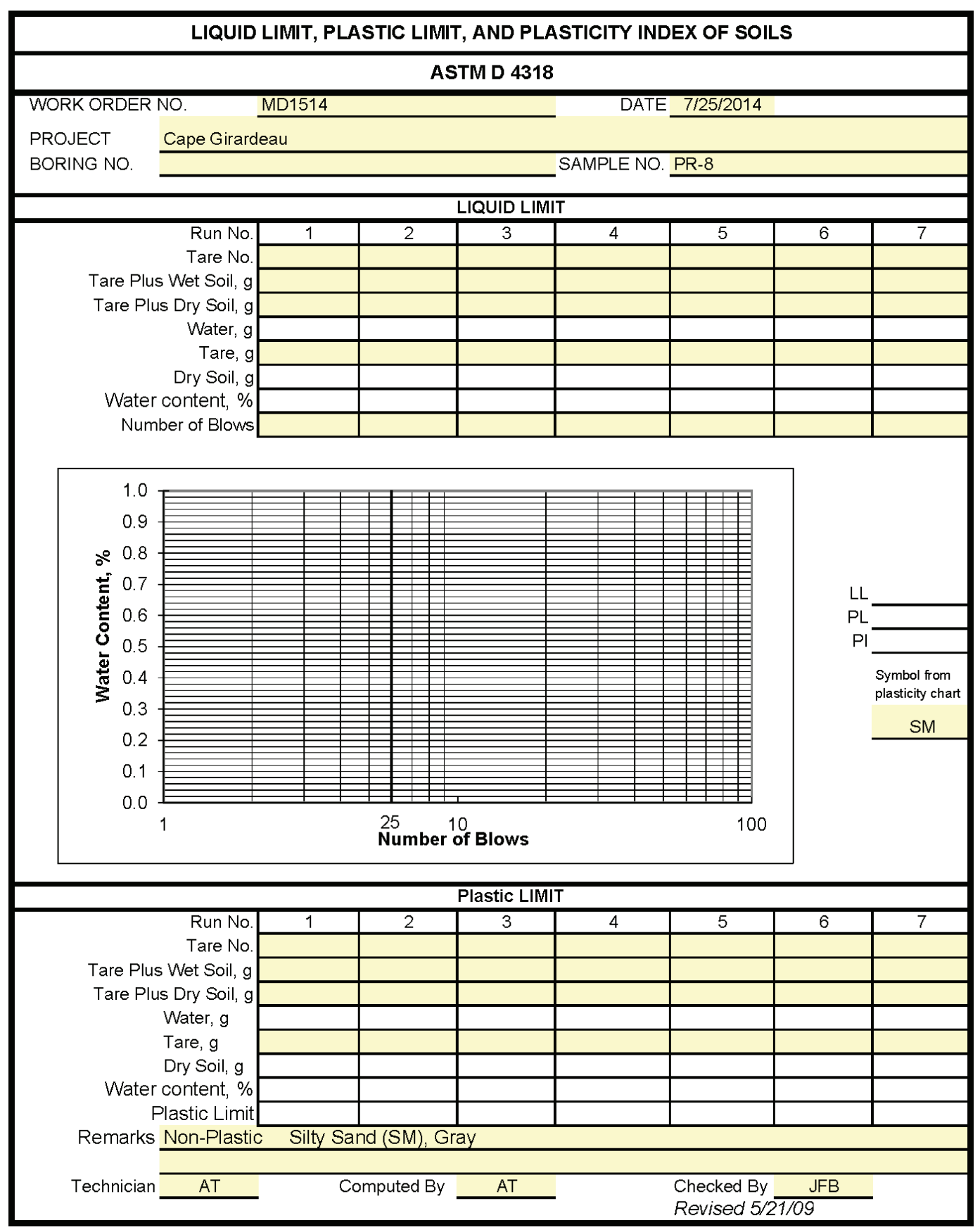




\section{Appendix B: CPT Boring Logs}




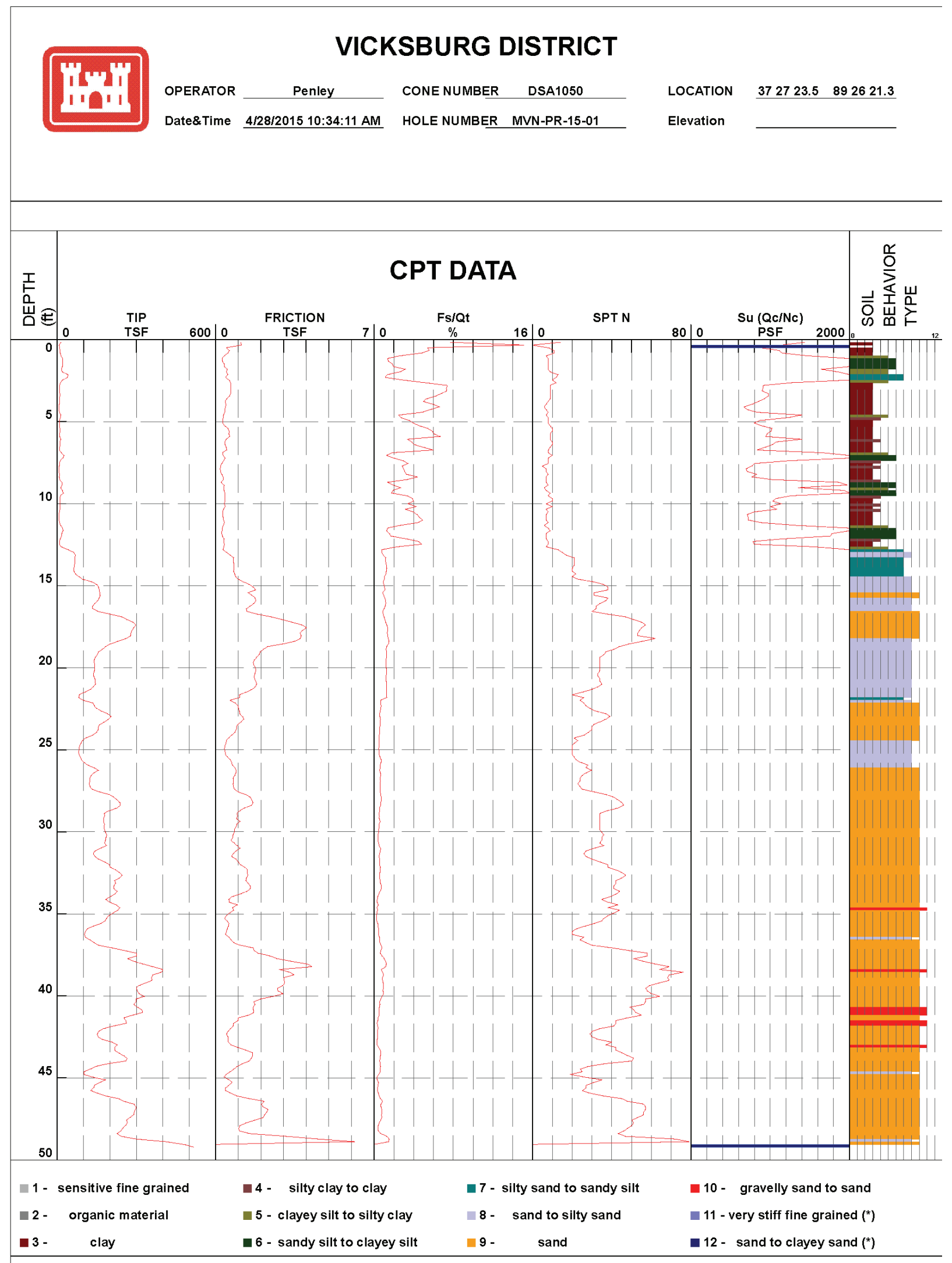




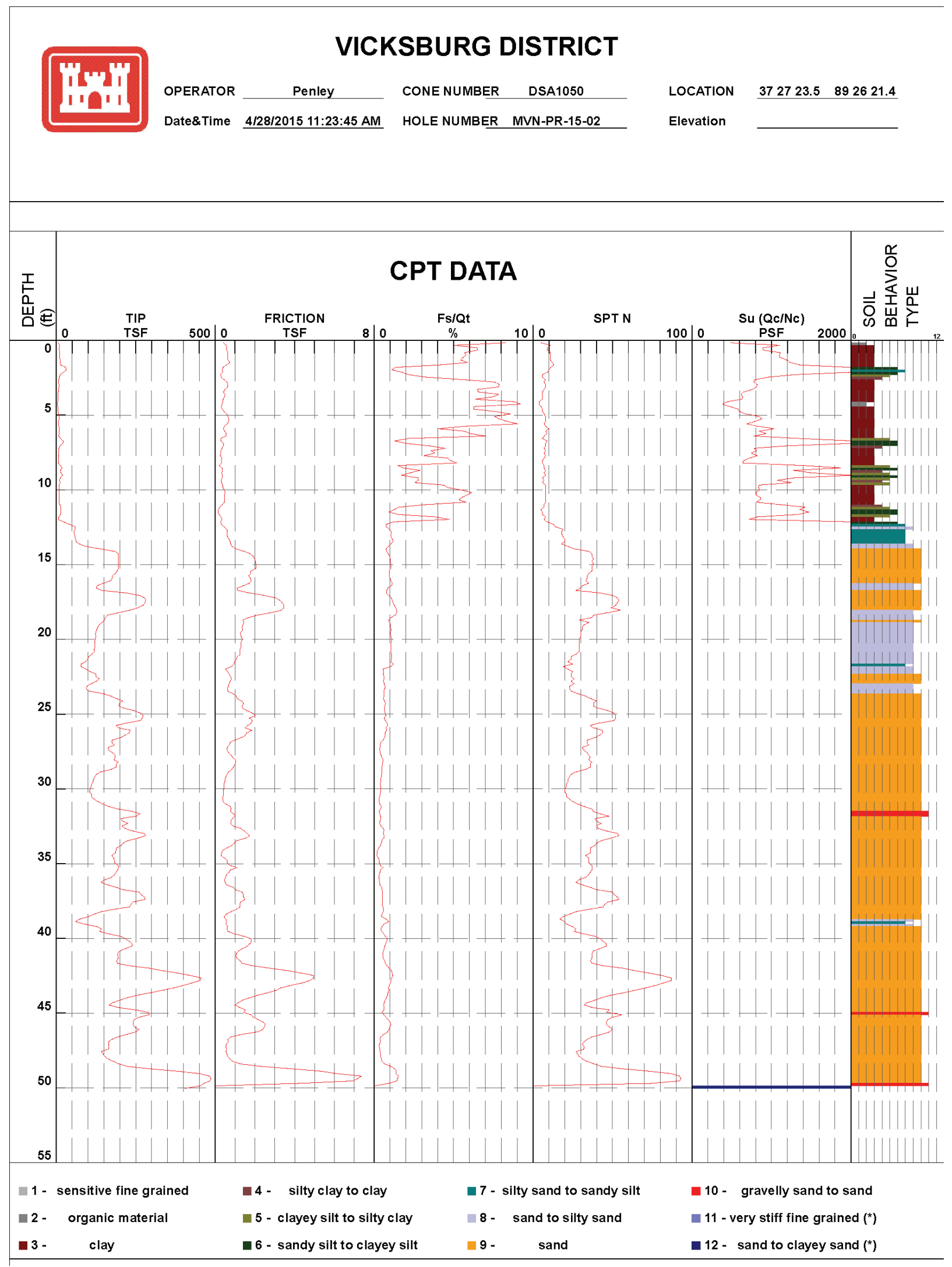




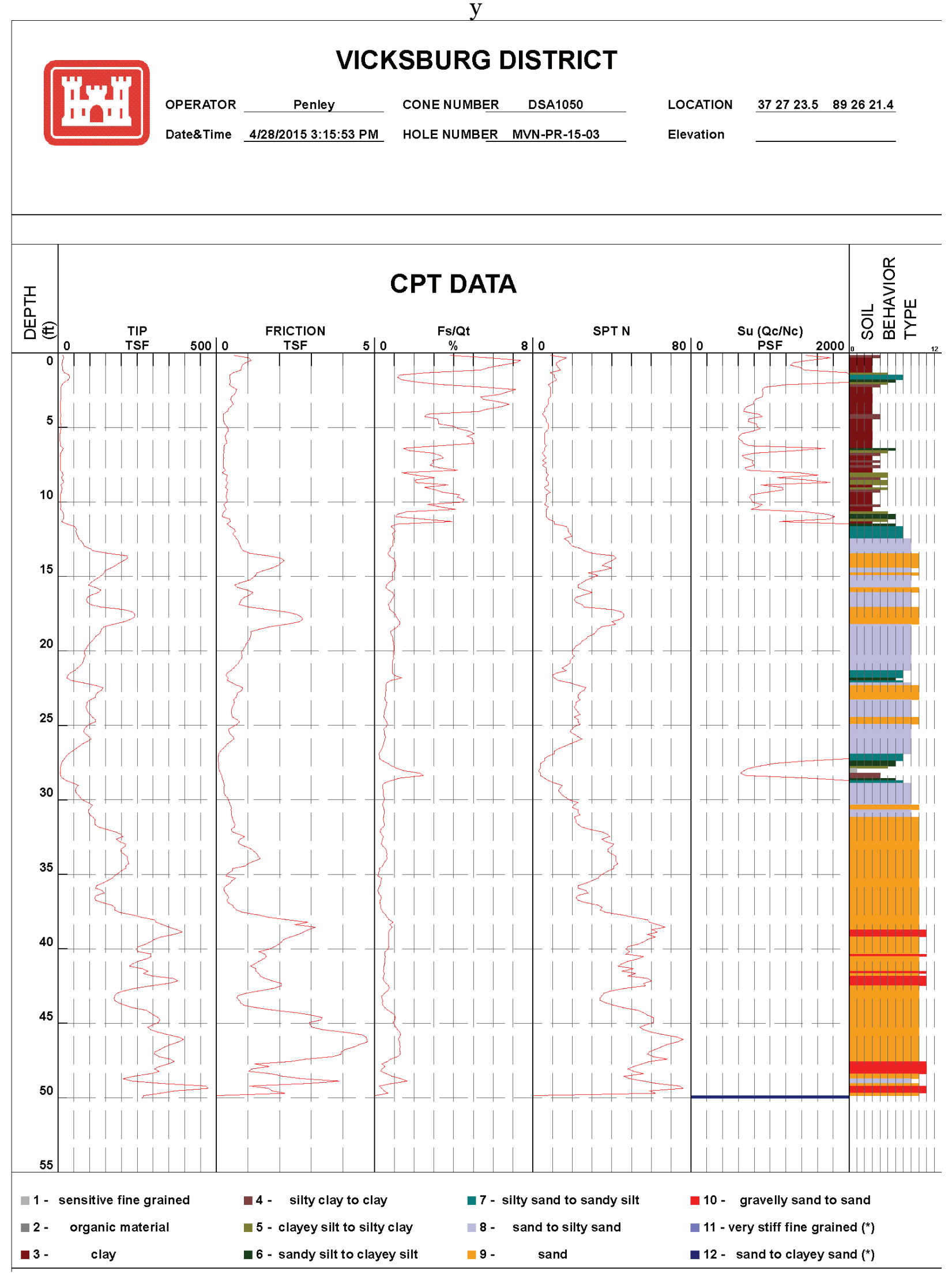




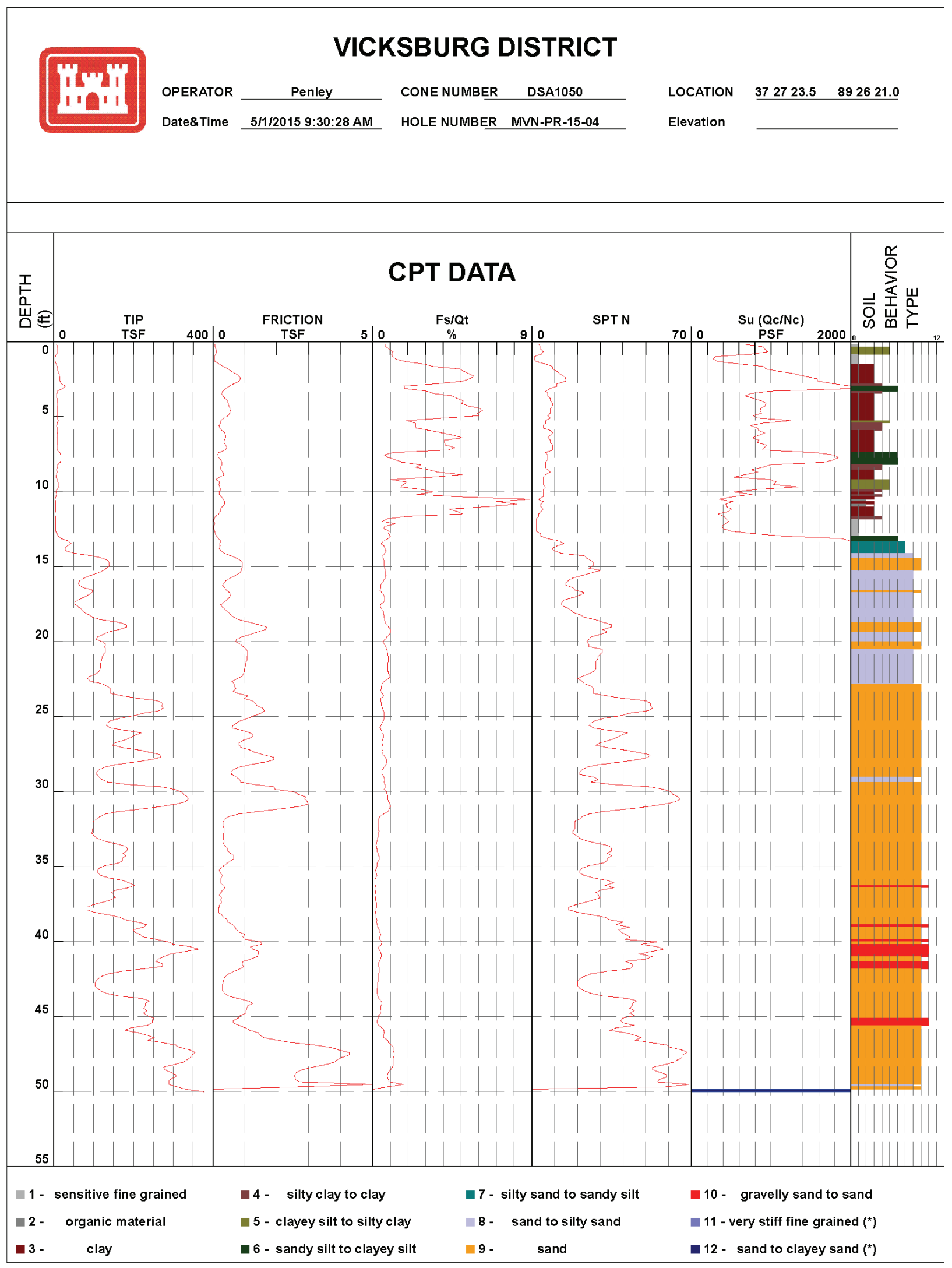




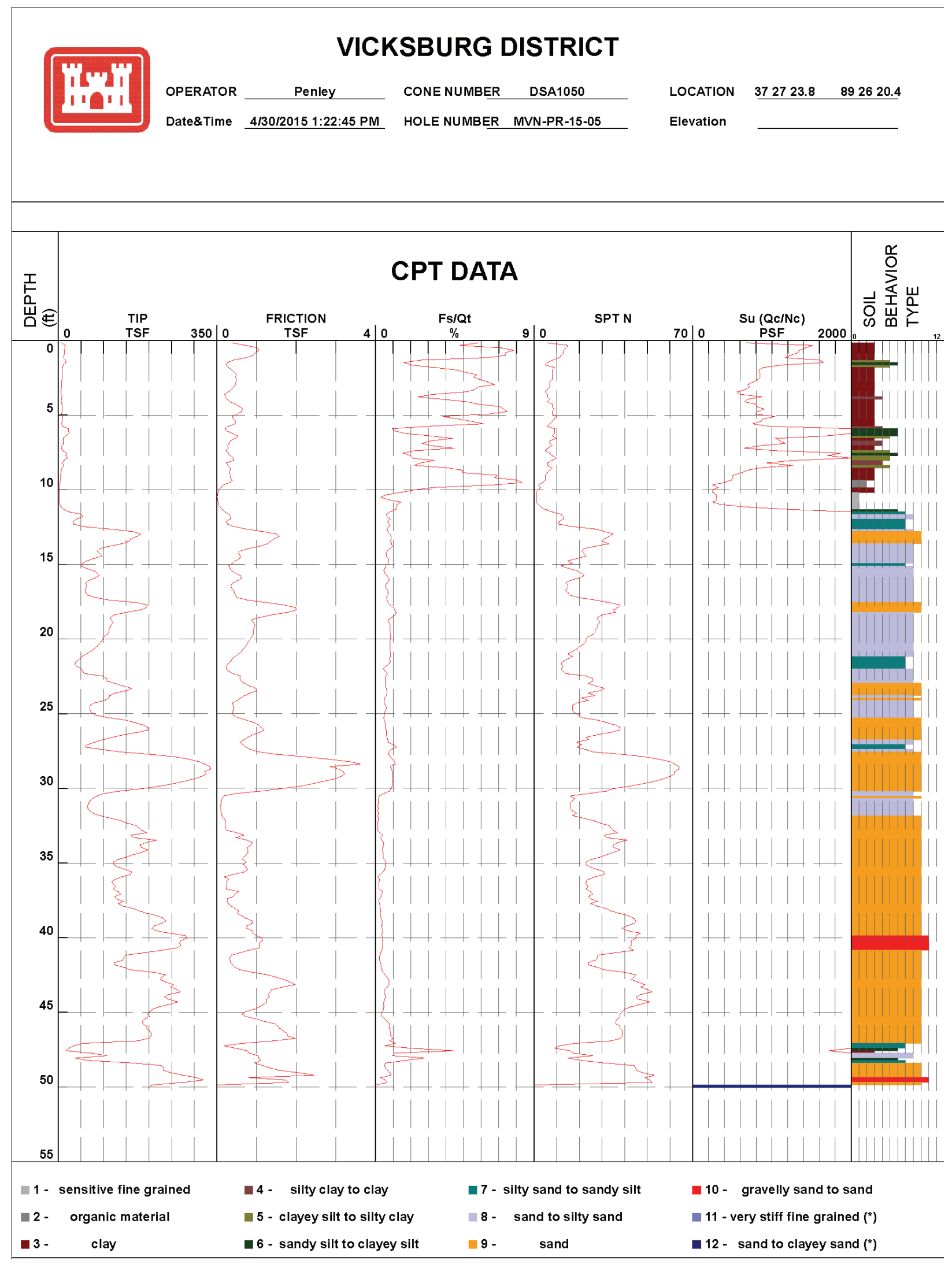




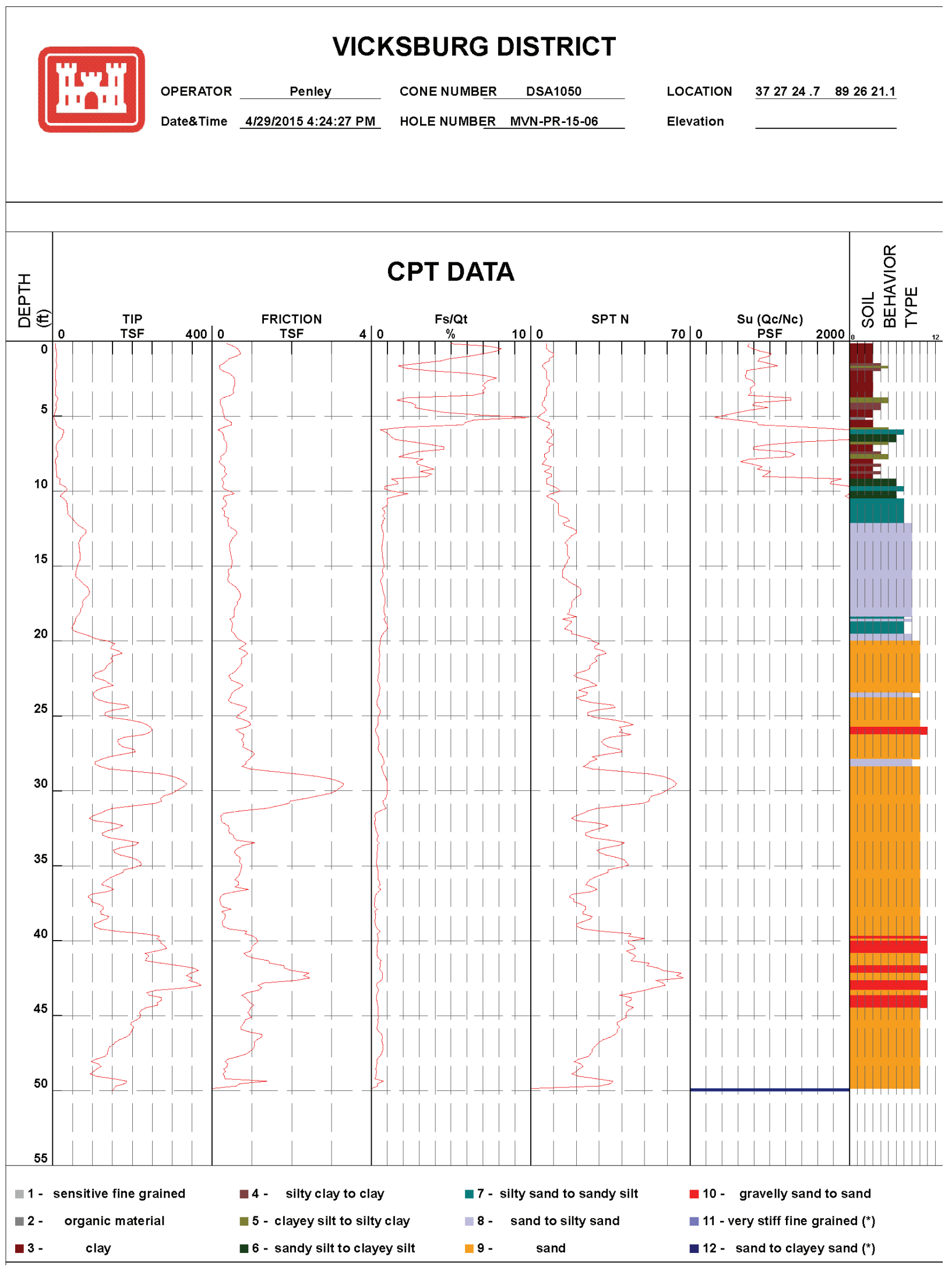




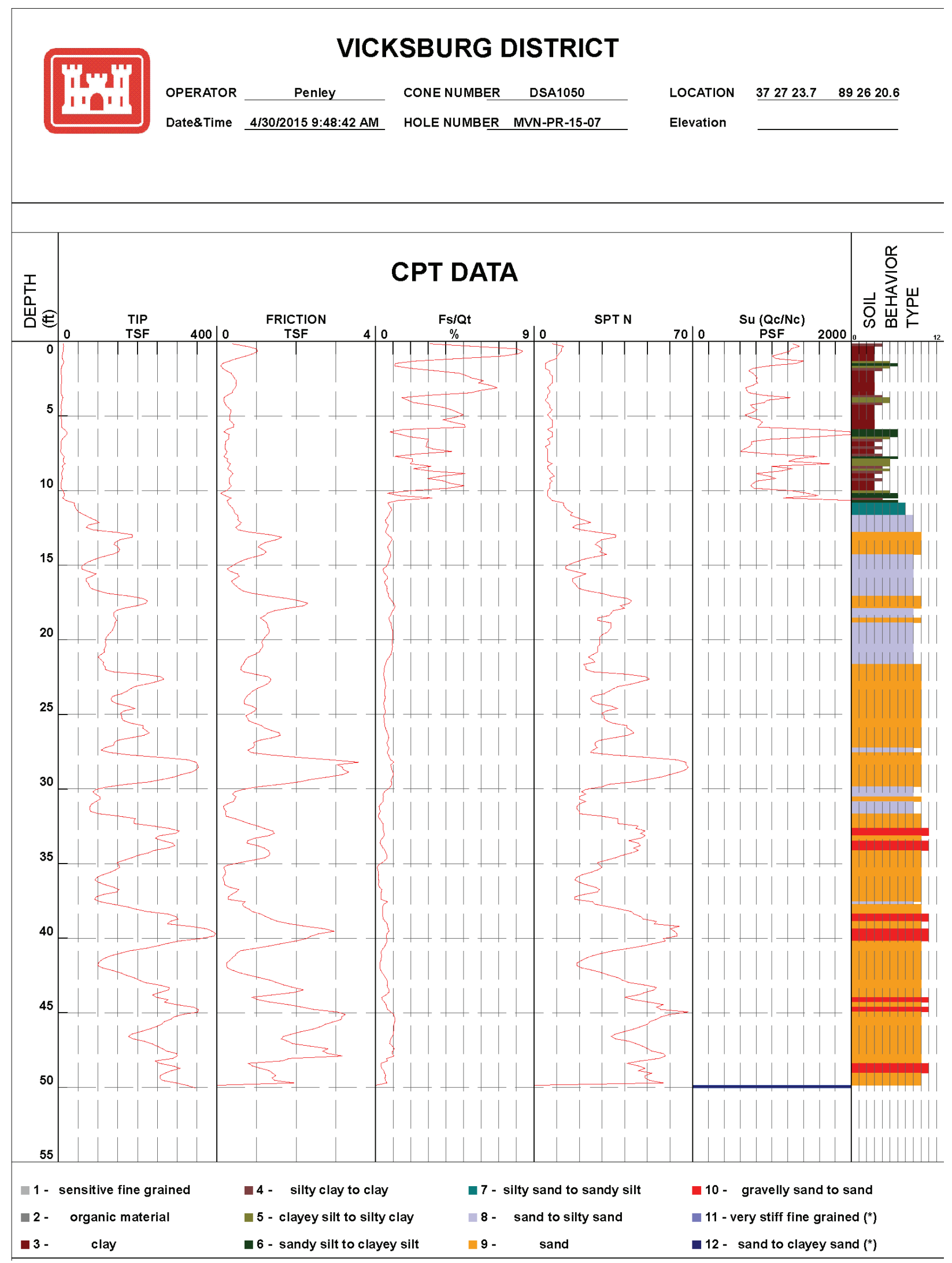




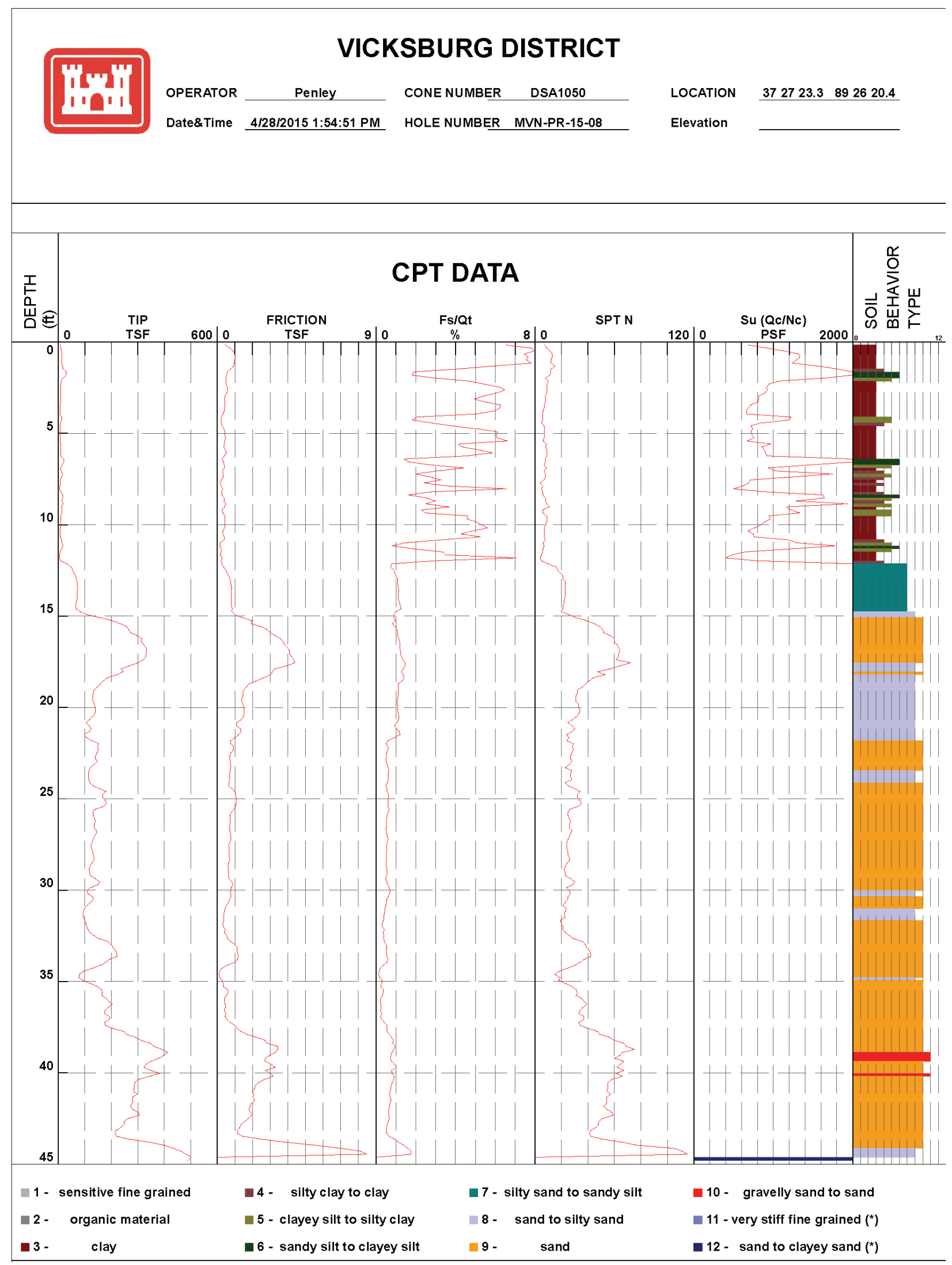




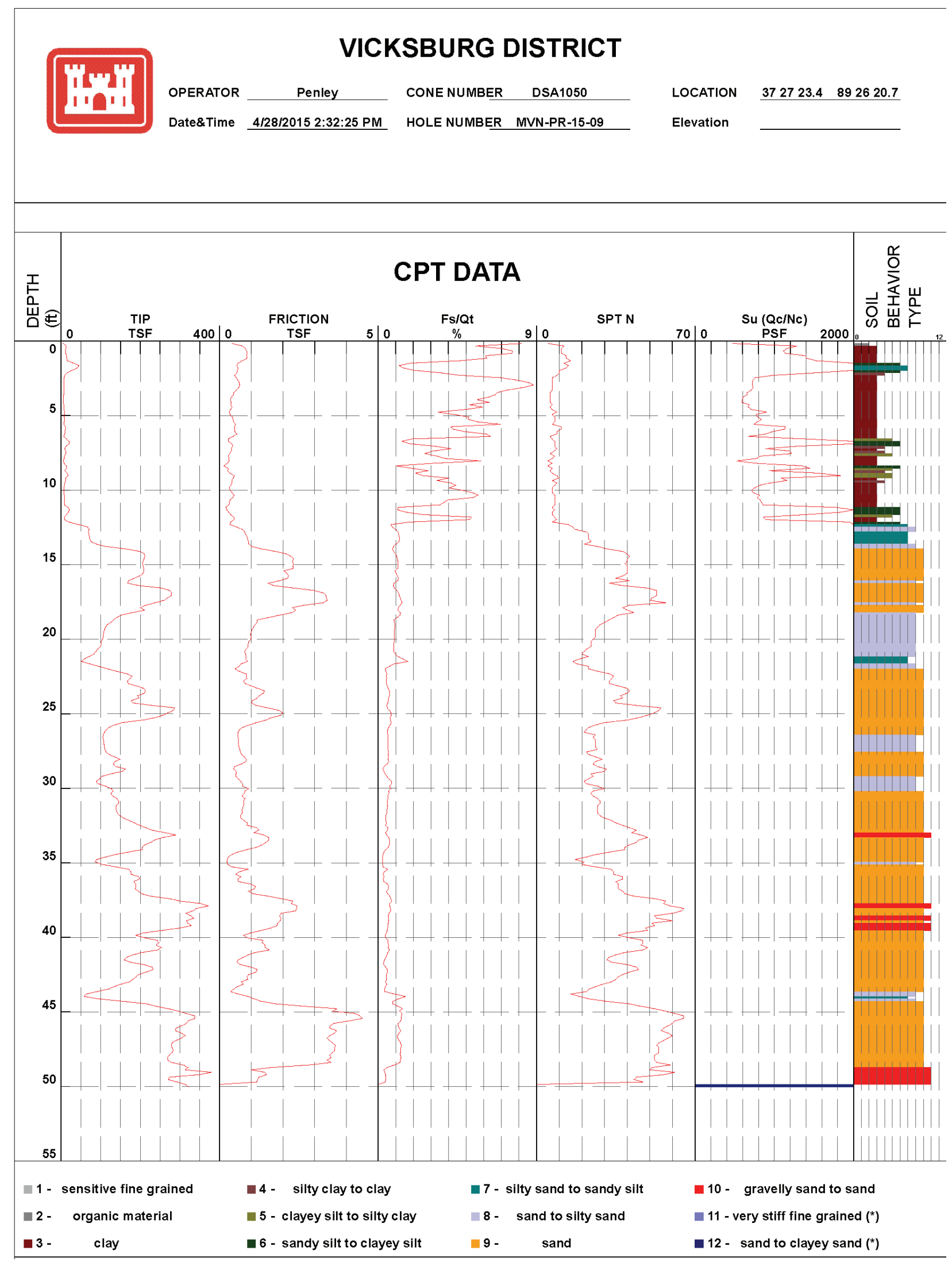




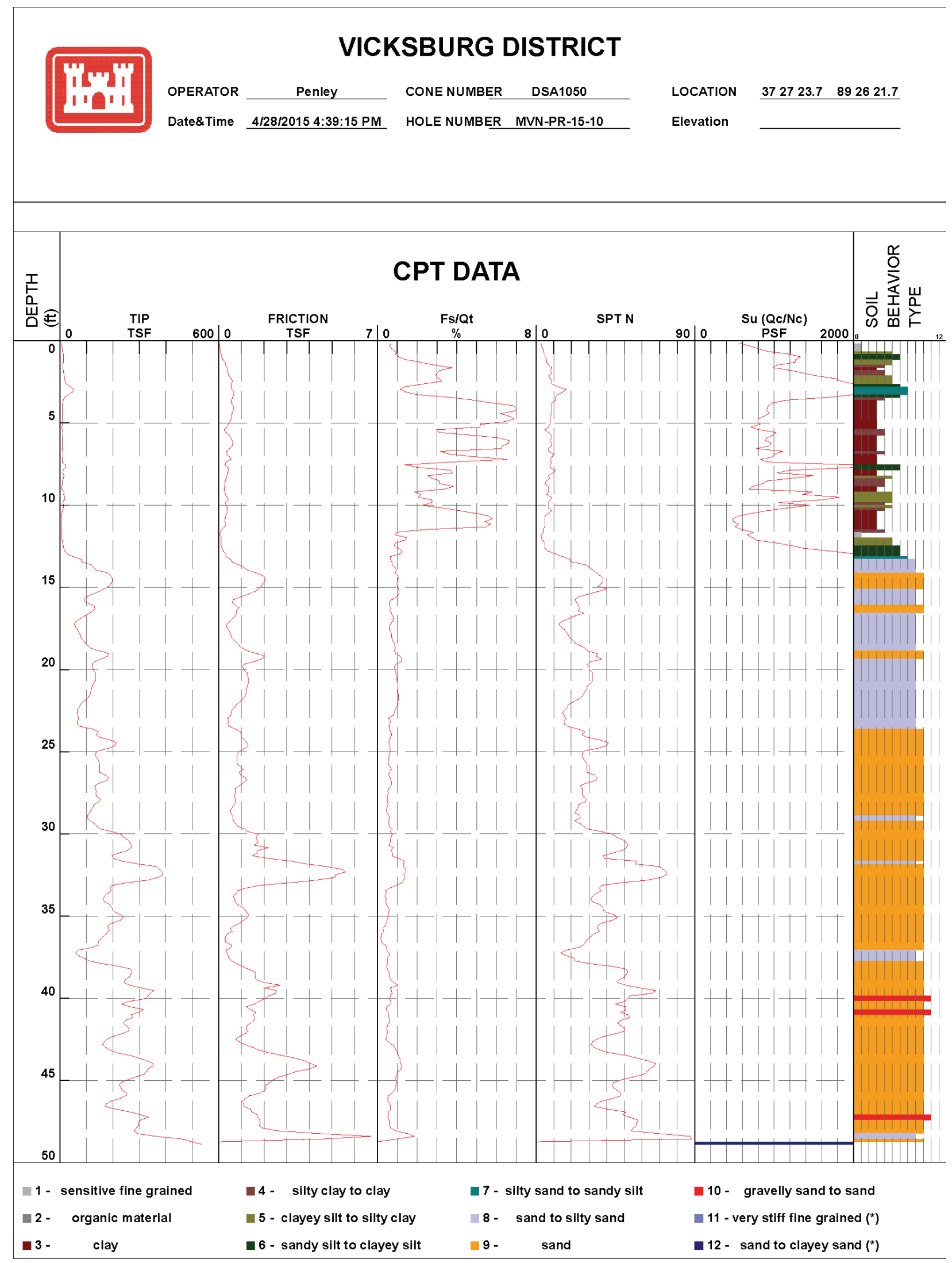




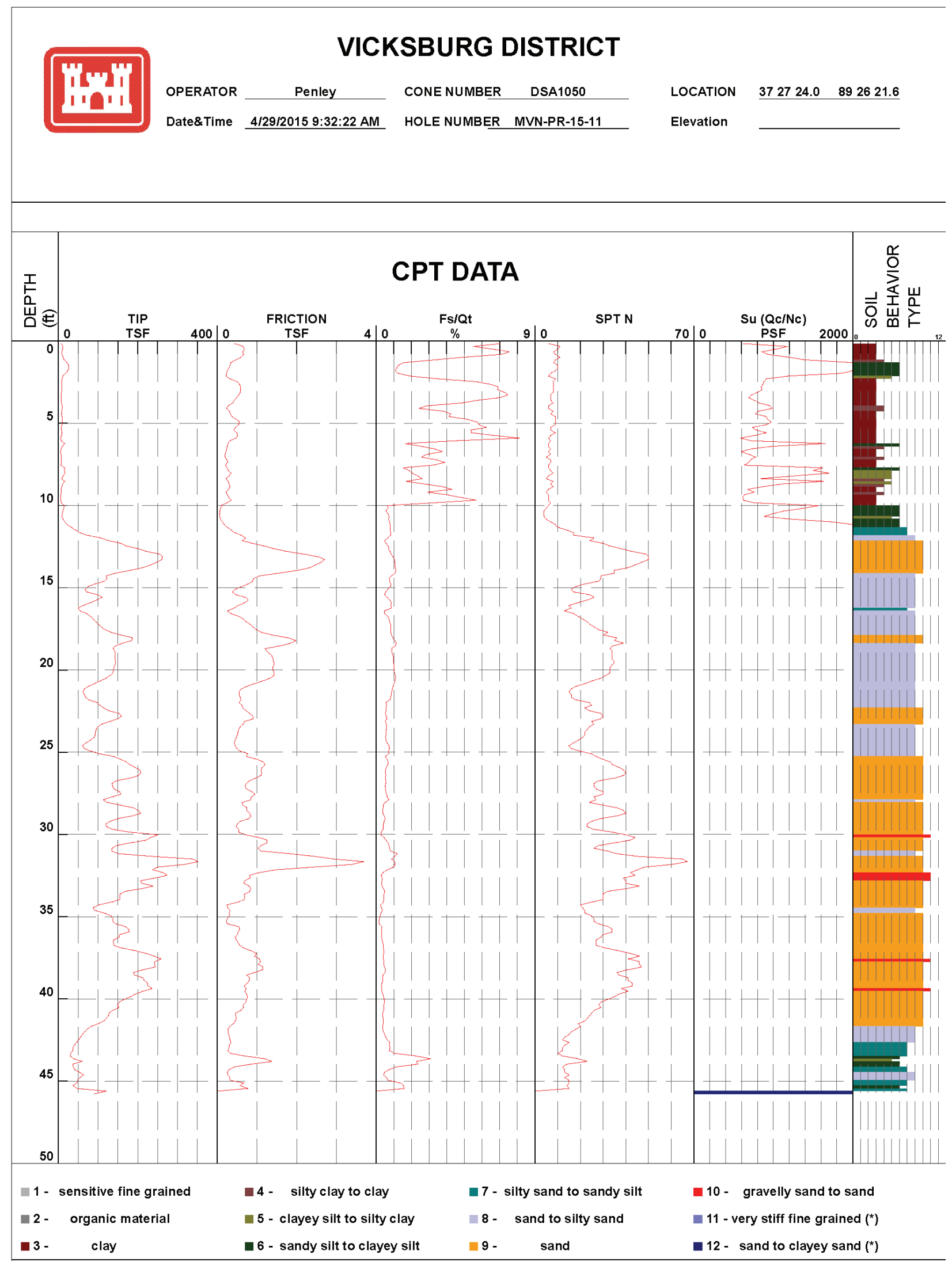




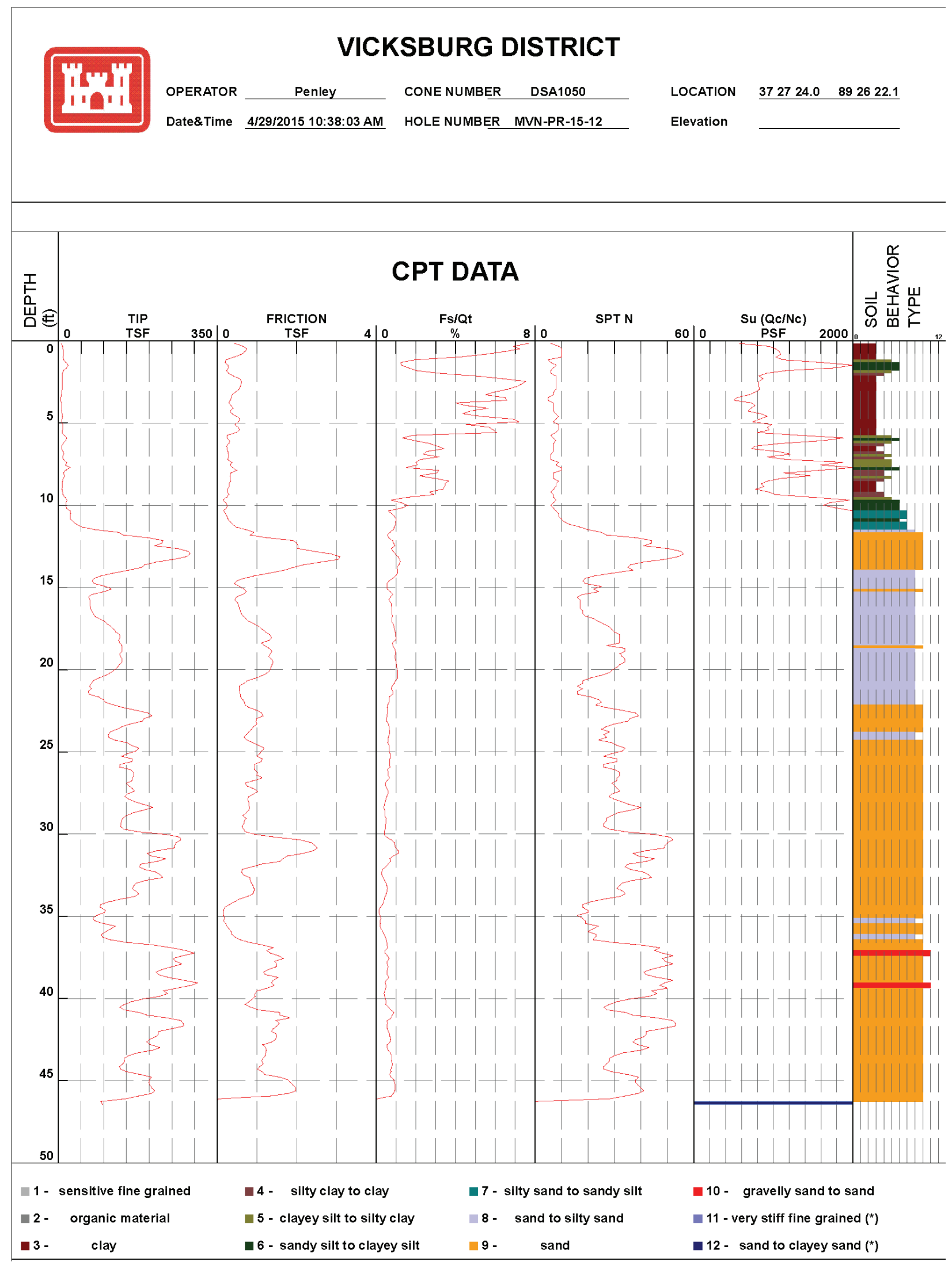




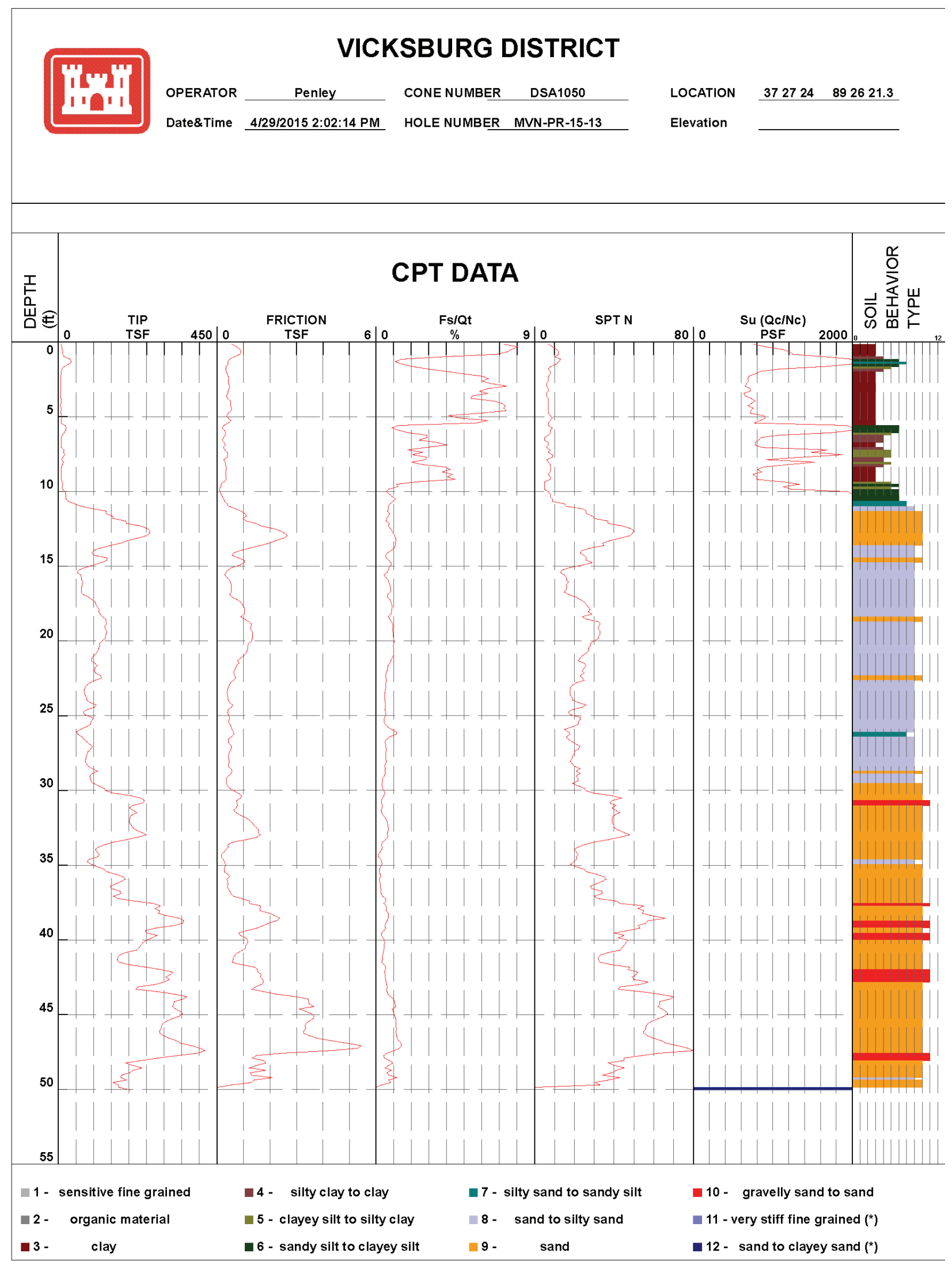




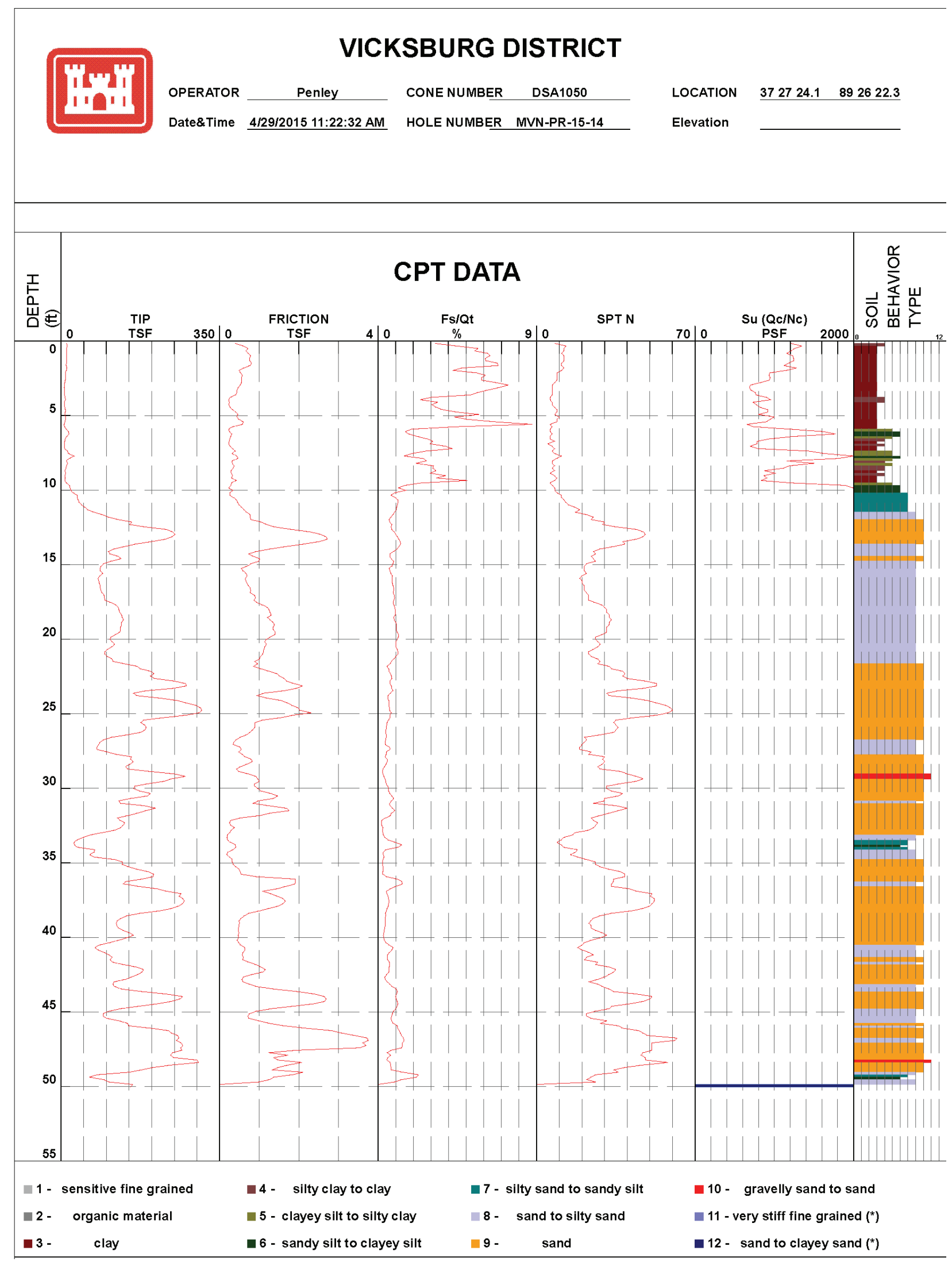




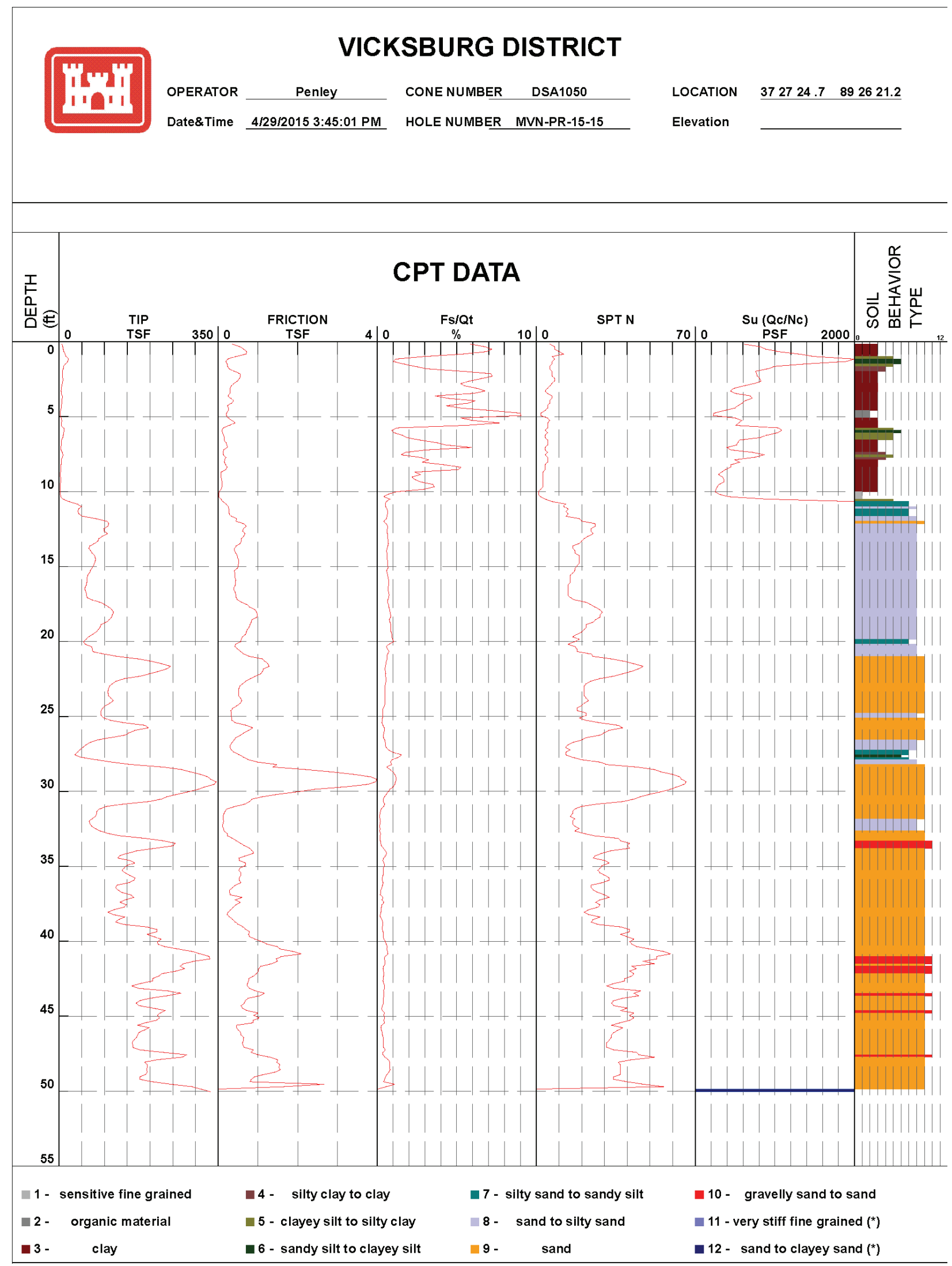




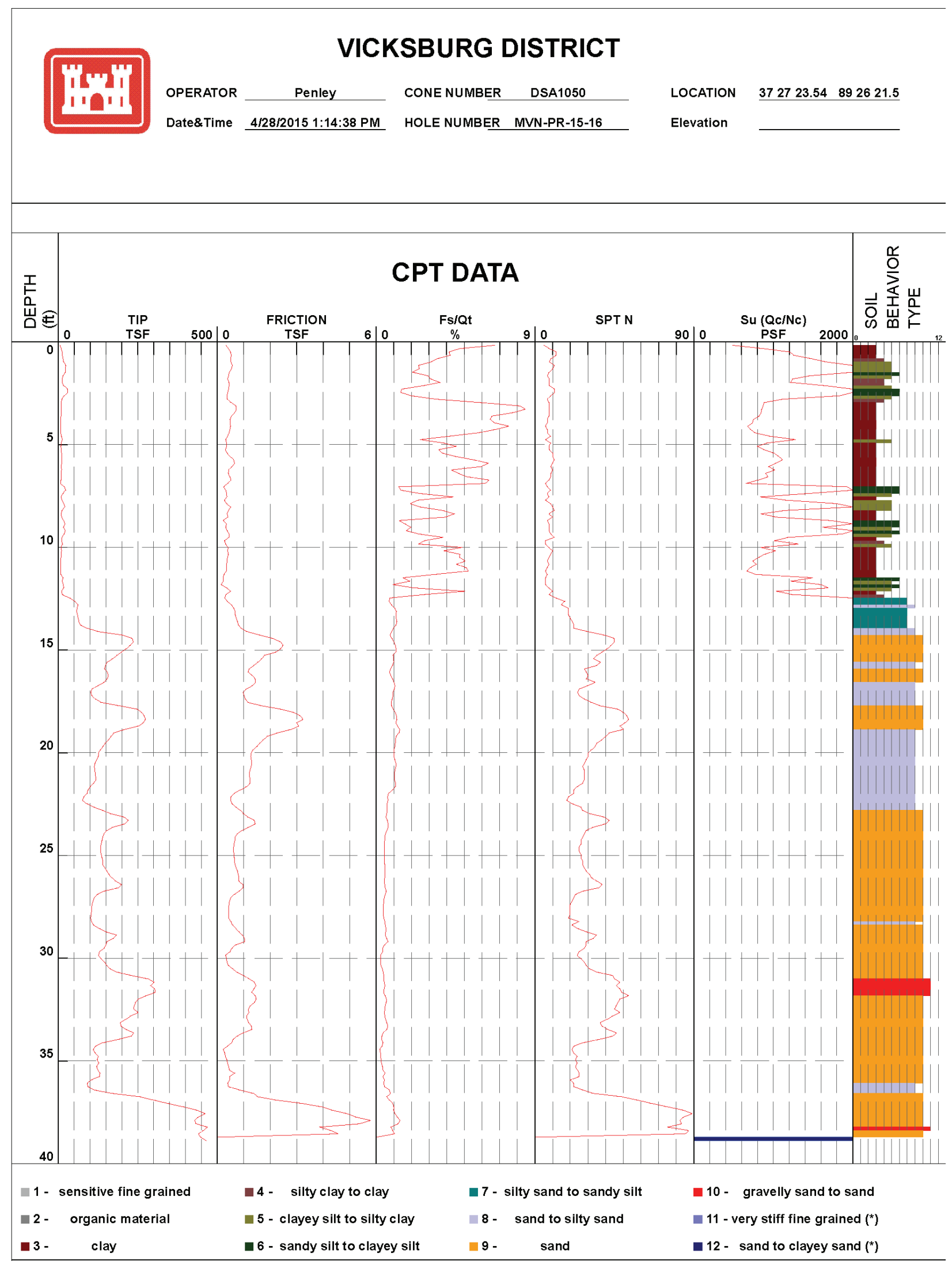




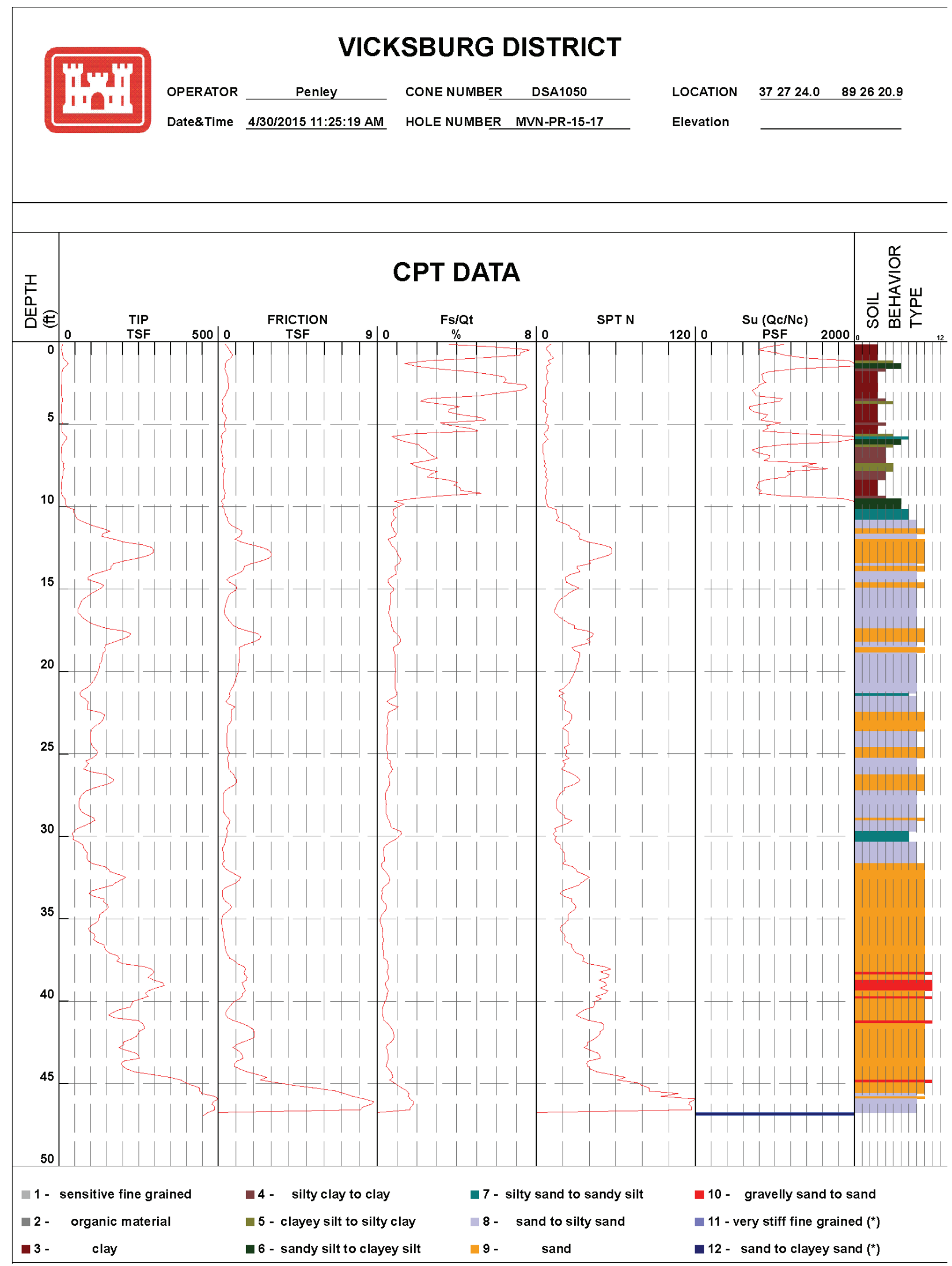




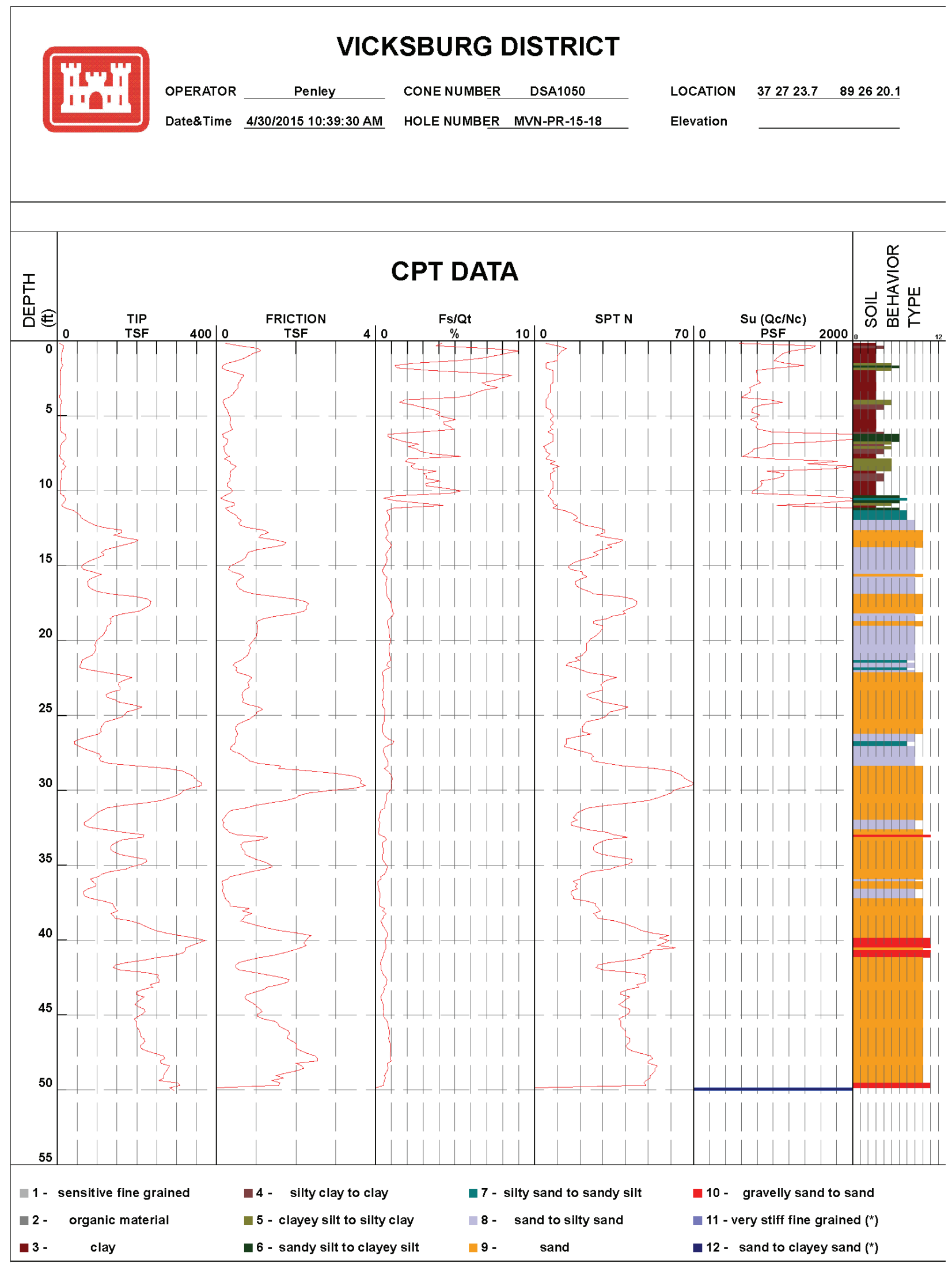




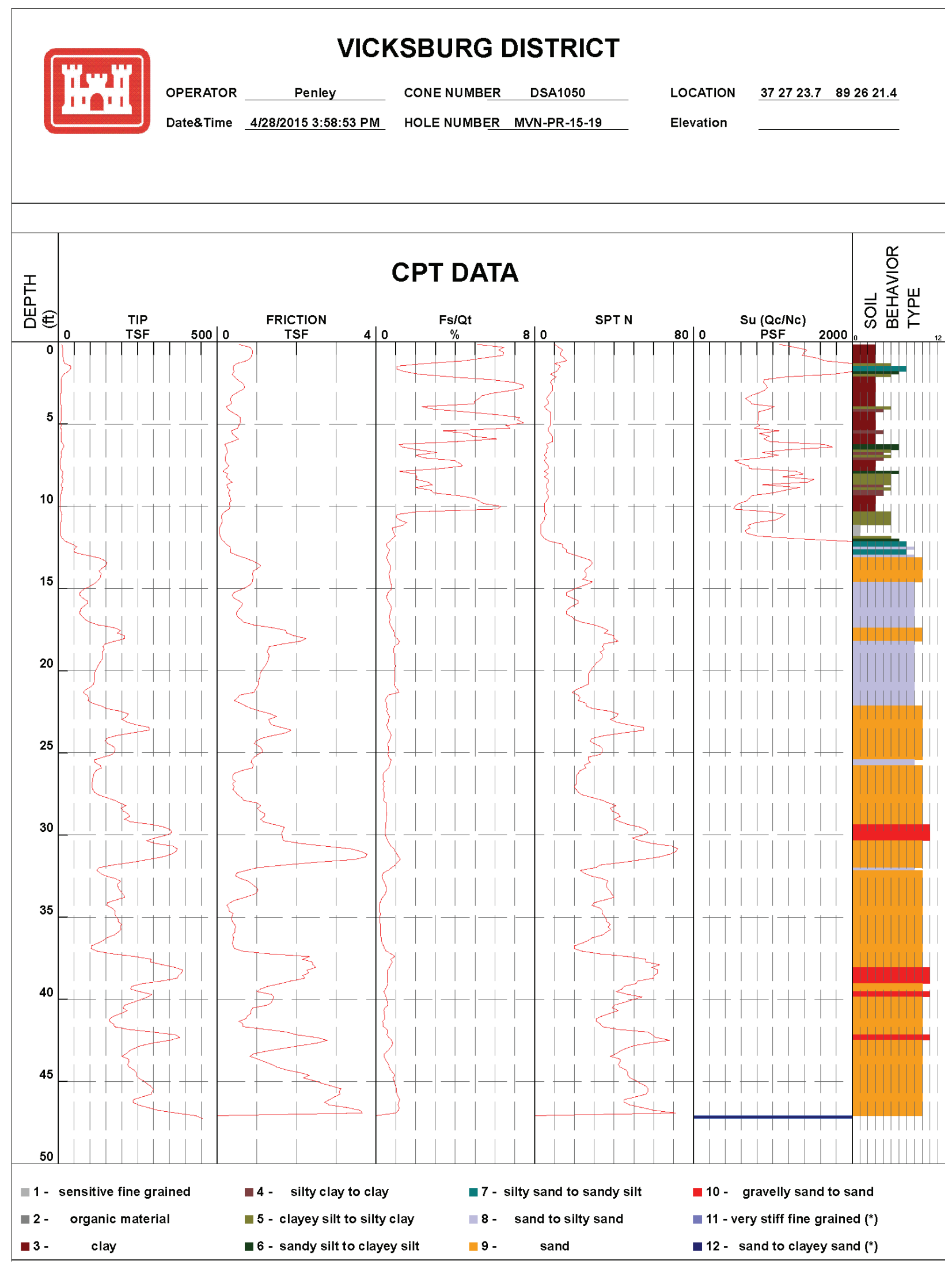




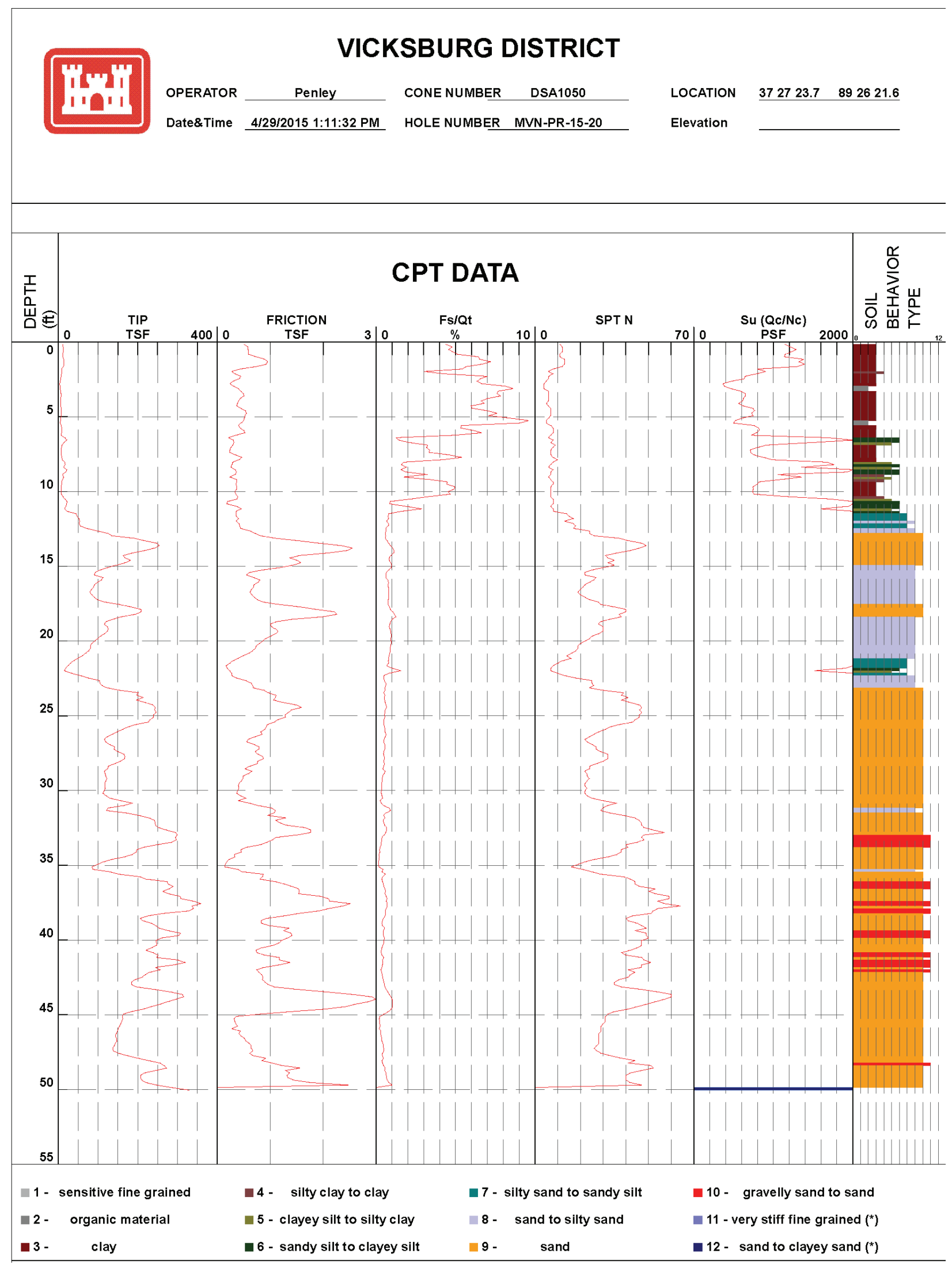




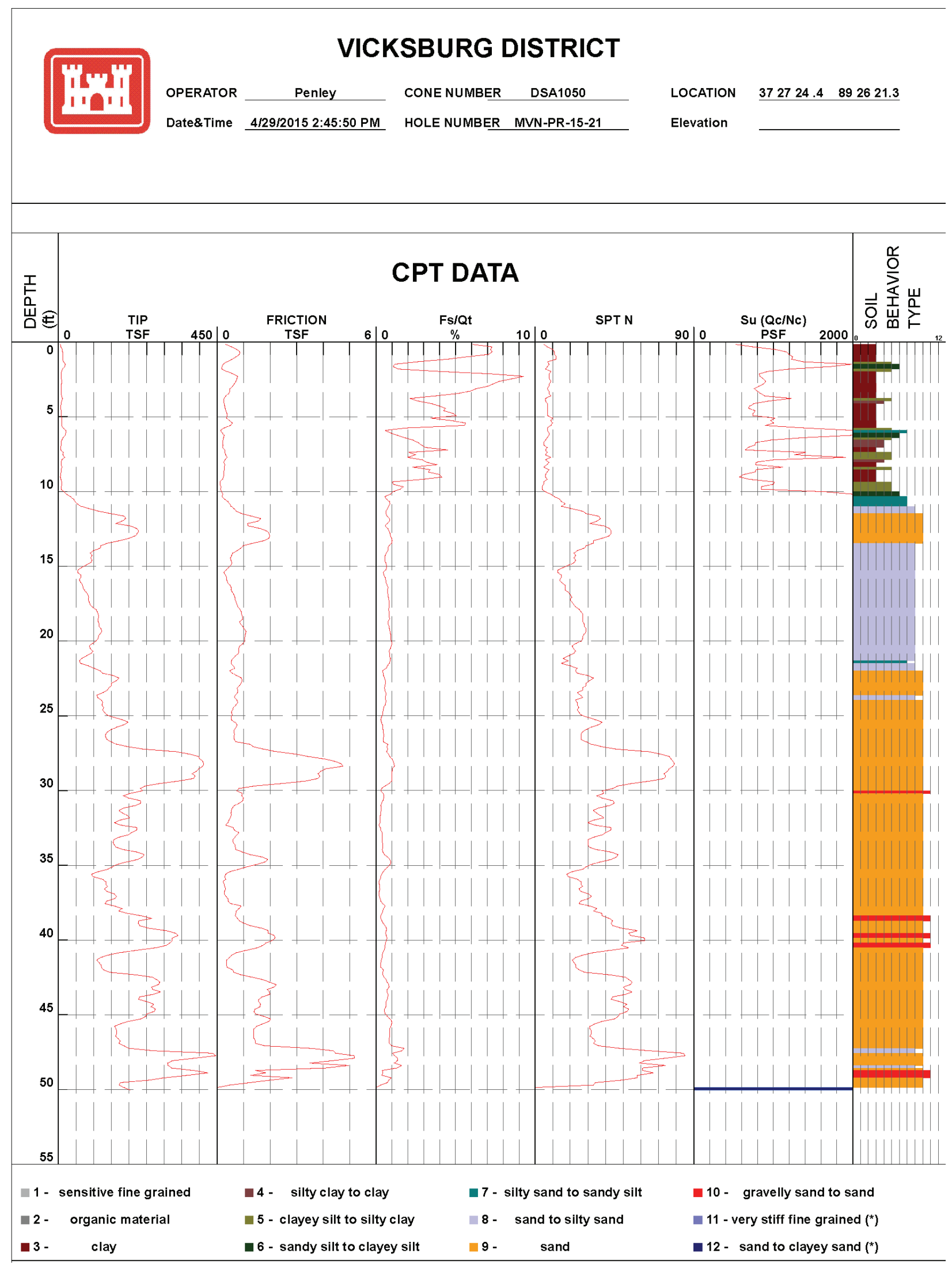




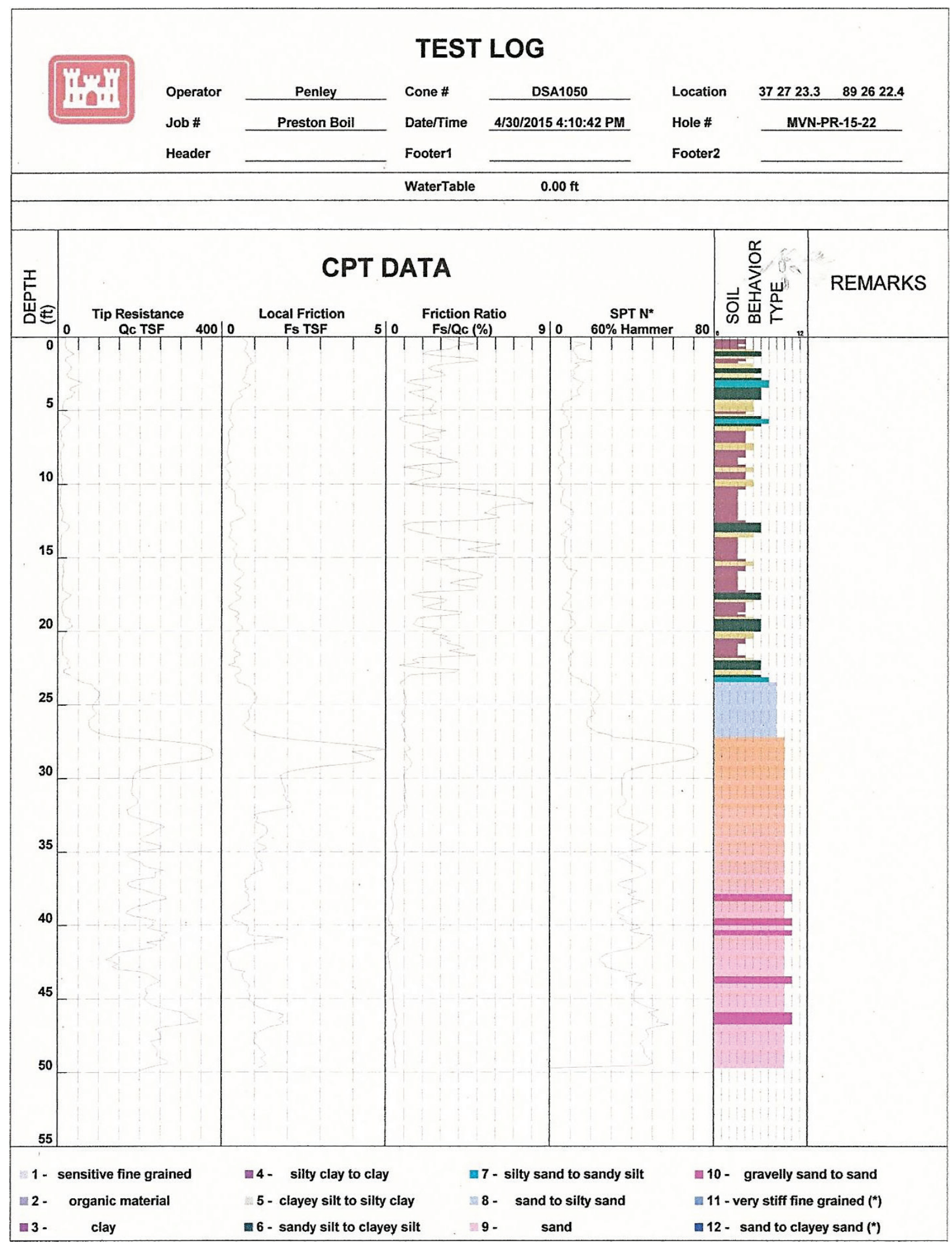




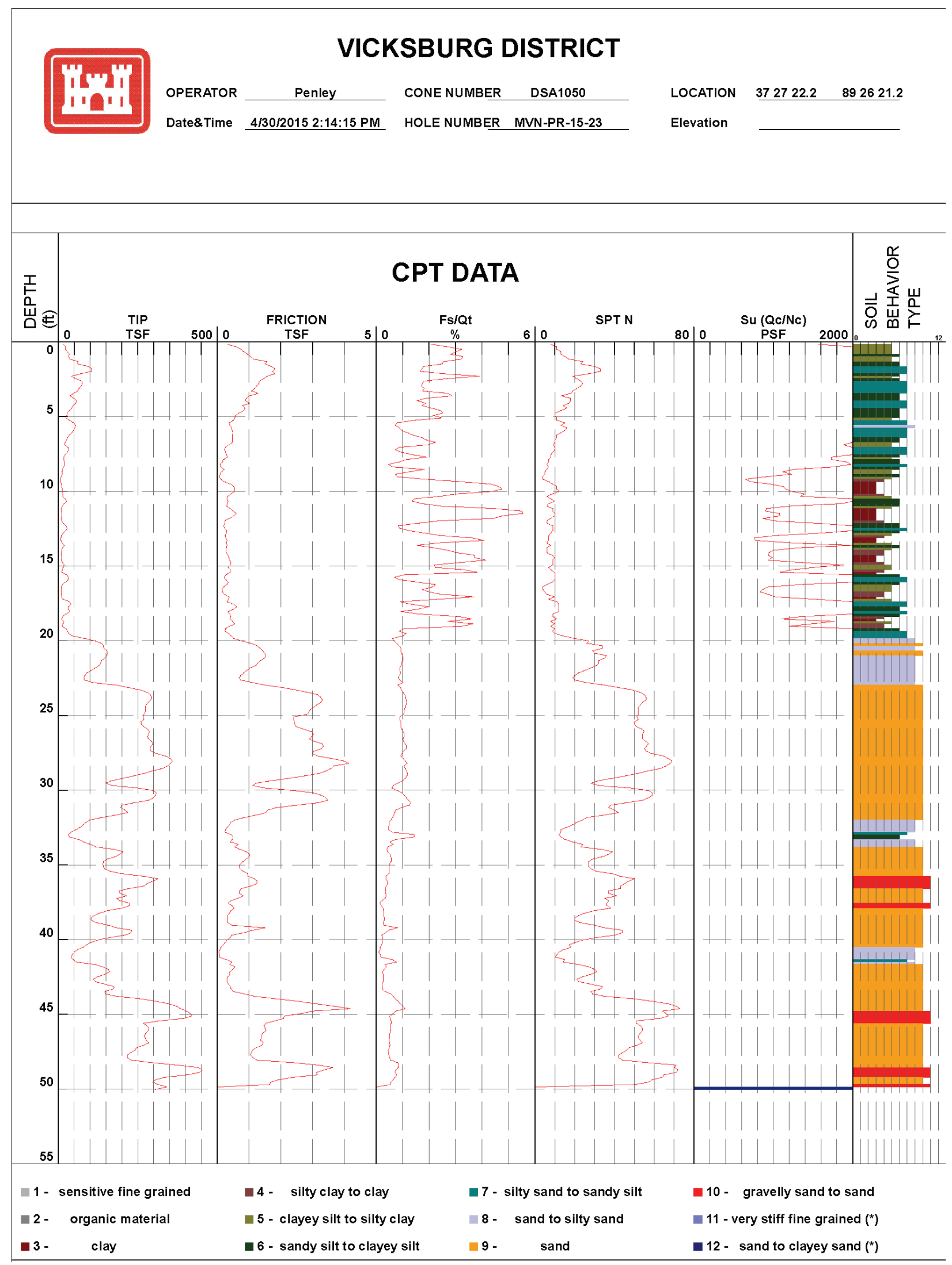




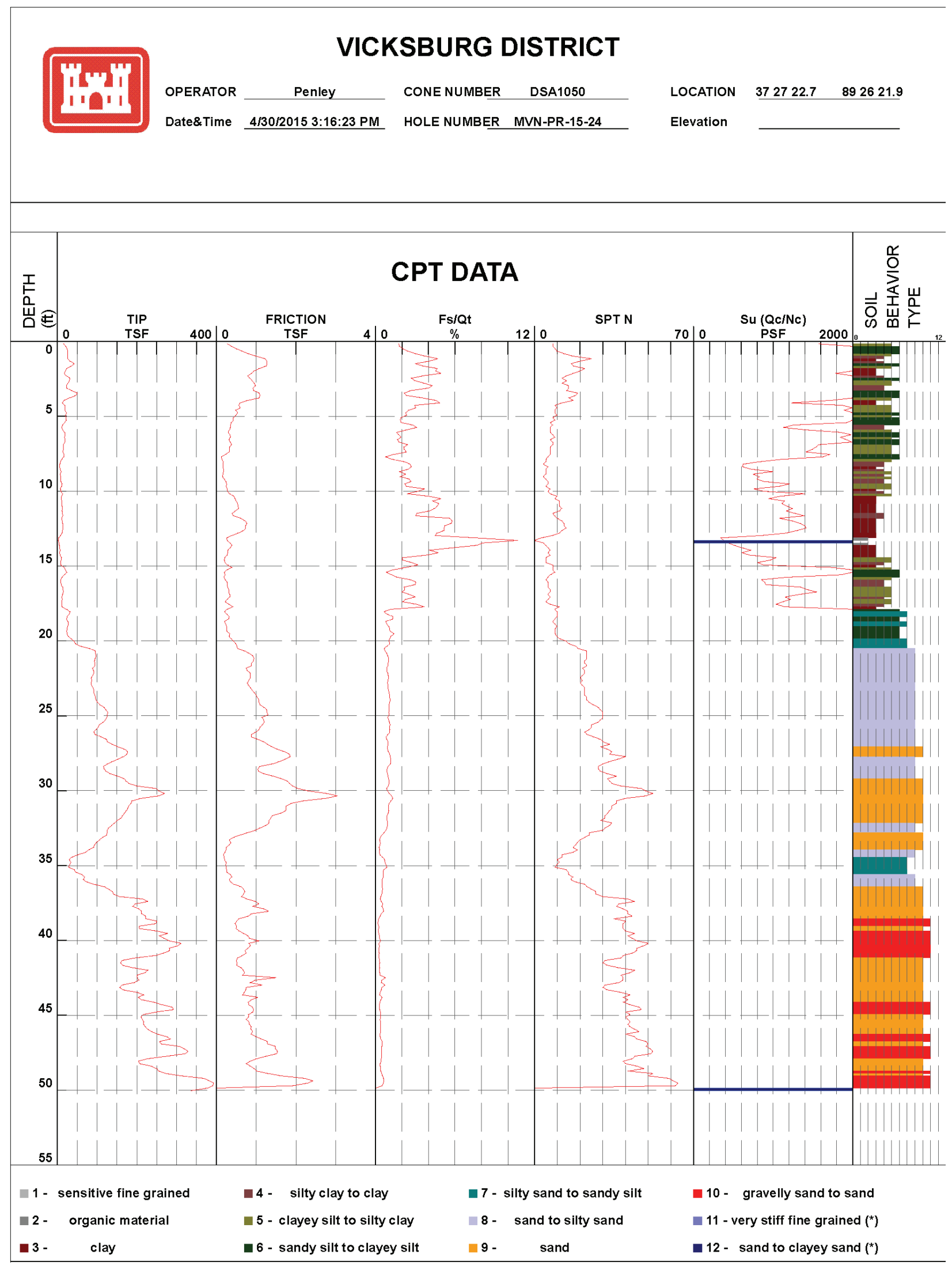




\section{Appendix C: Boring Logs for Split Spoon Samples}




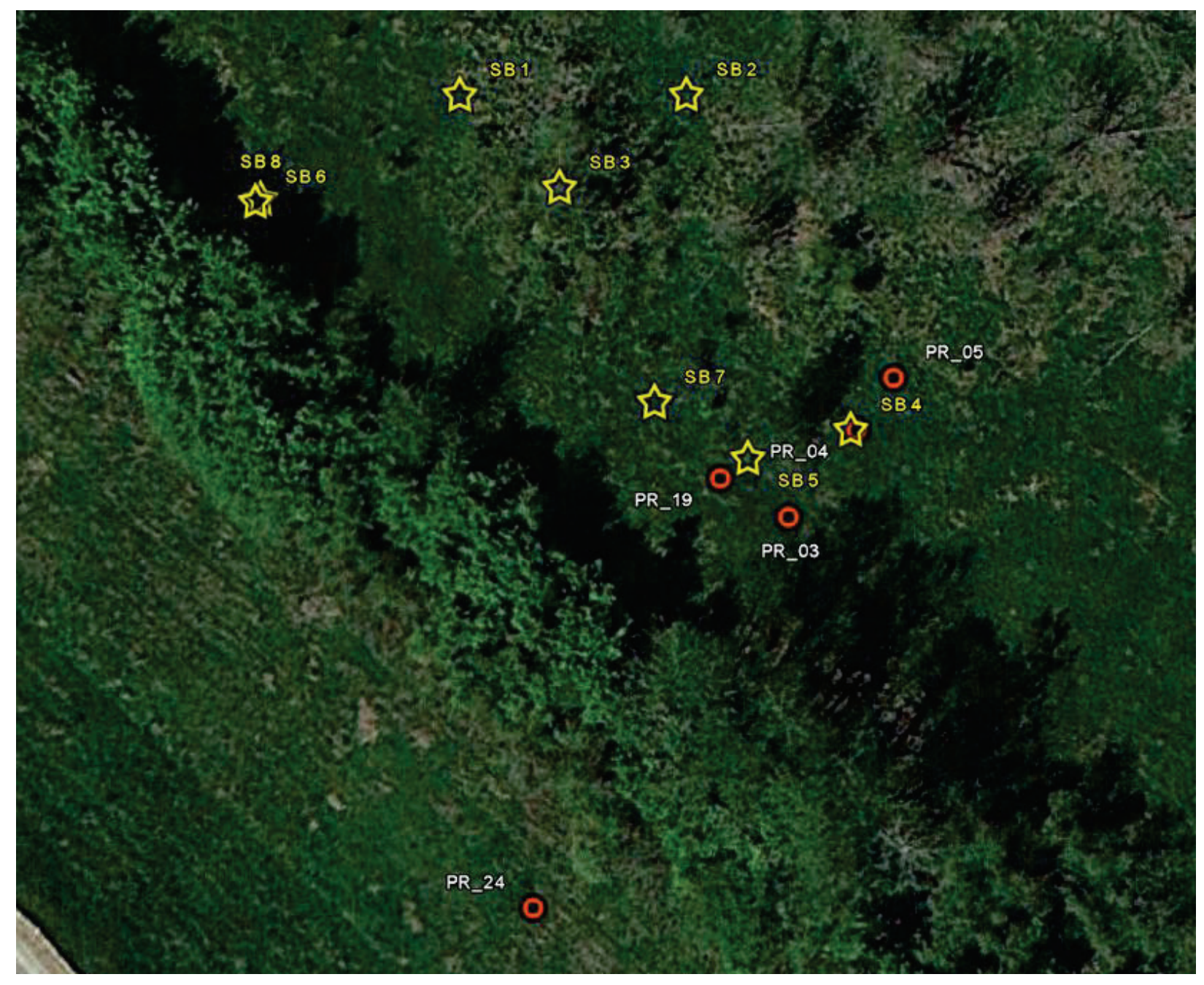

\section{Locations of Sample Borings}




\section{MVN-PR-15-04}

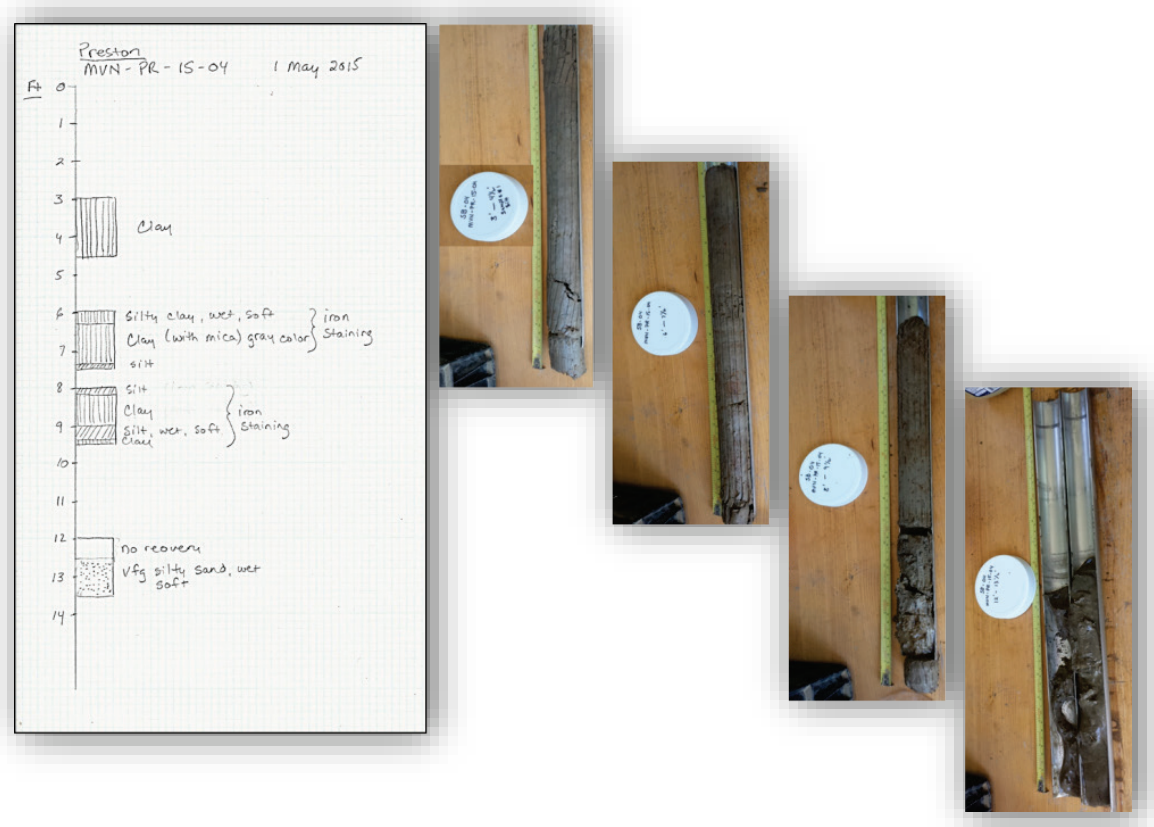

MVN-PR-15-03
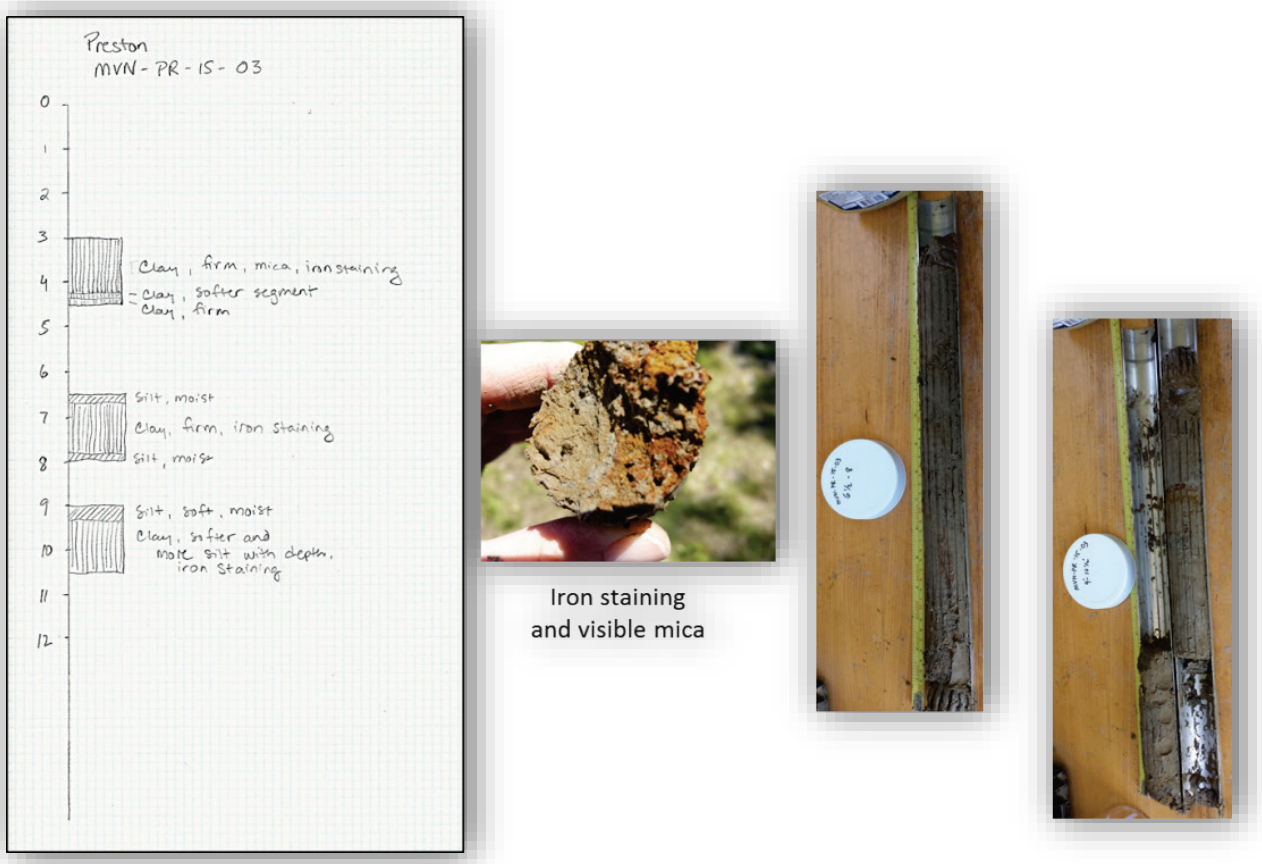


\section{MVN-PR-15-05}
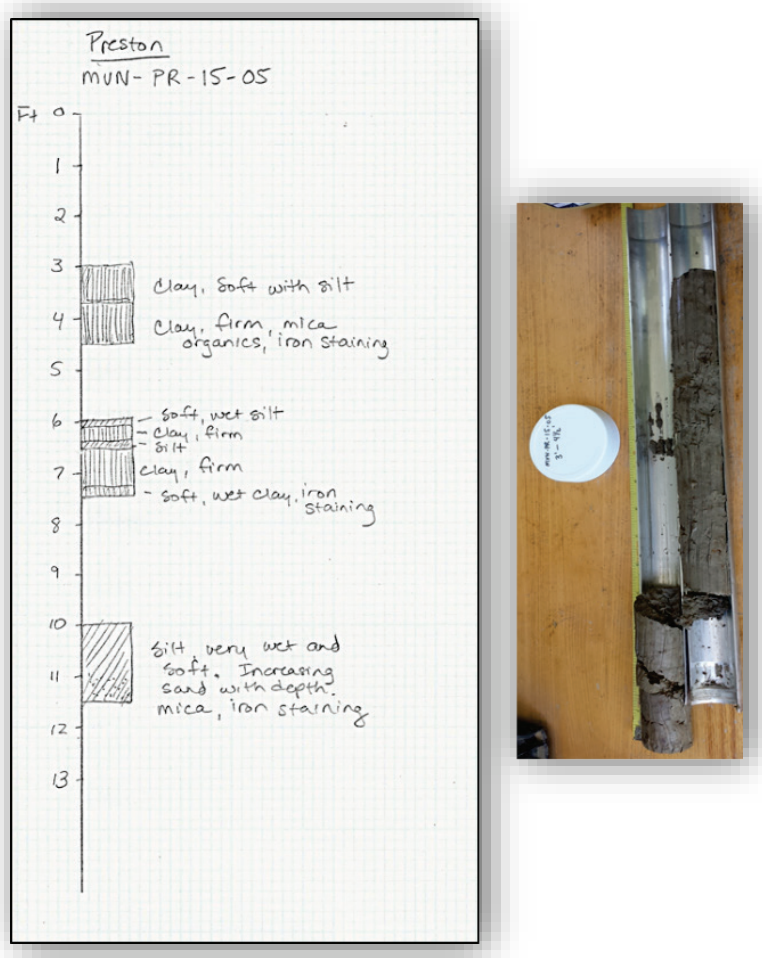

\section{MVN-PR-15-19}
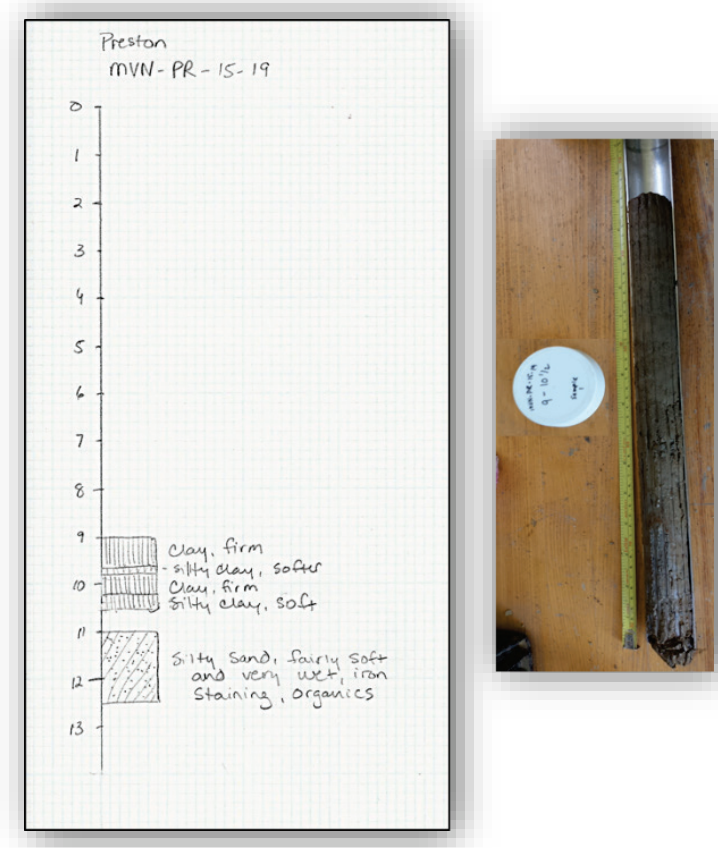


\section{MVN-PR-15-24}
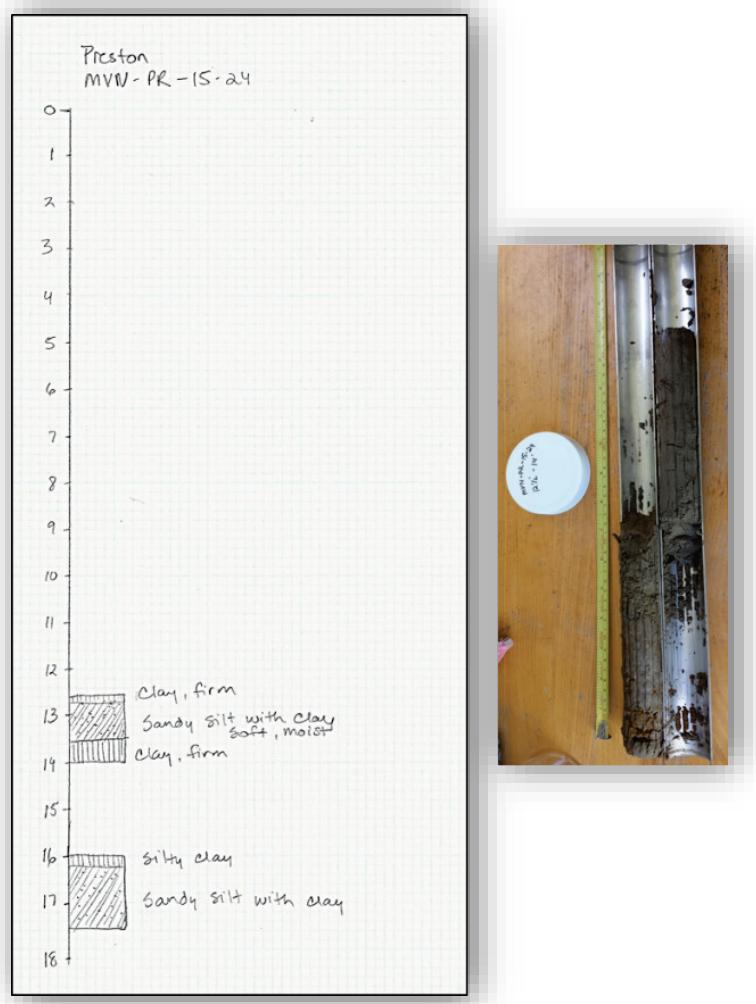


\section{Appendix D: Soil Curves from Split Spoon Samples}




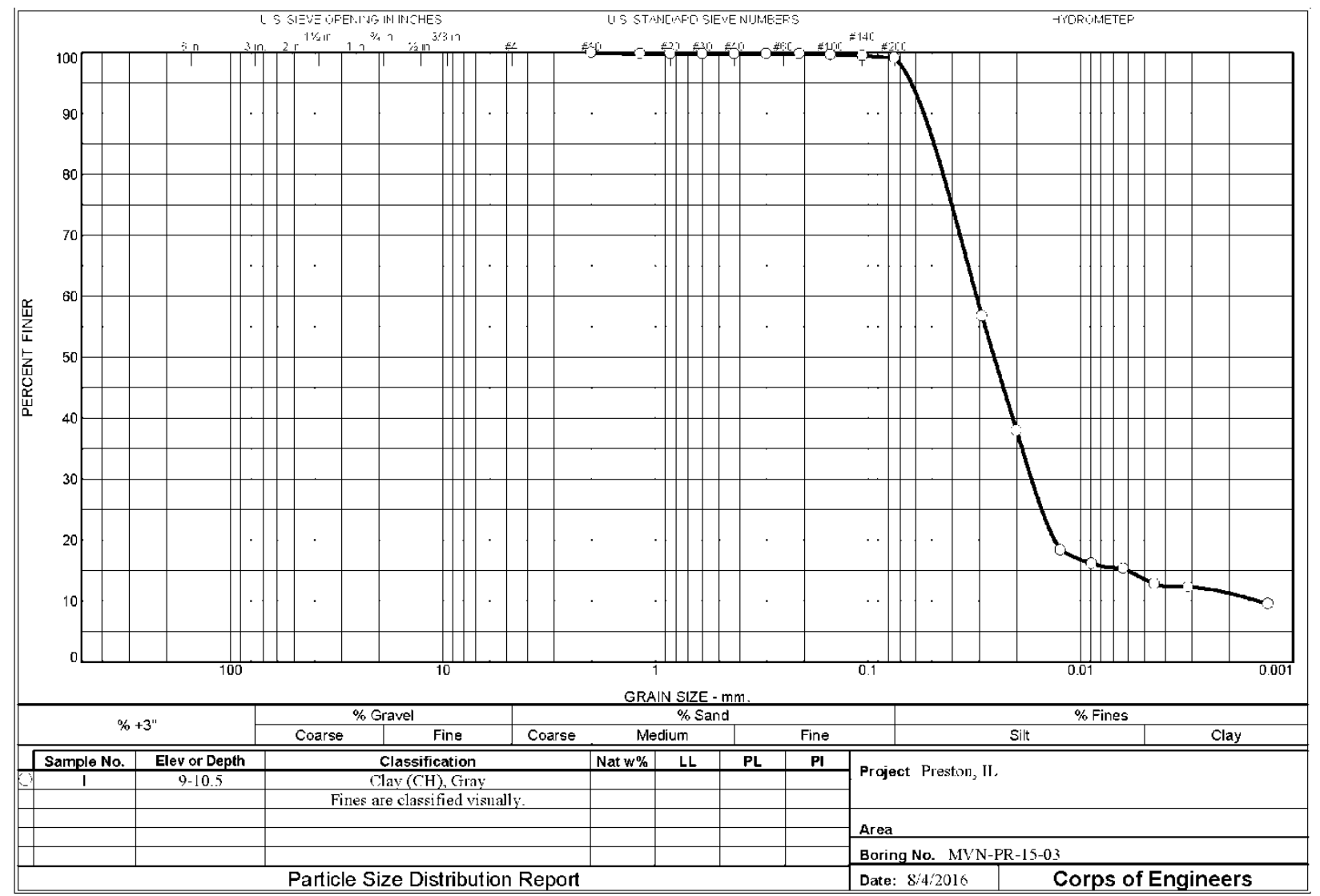

ENG 1 FORM 2087

Tested By: AT/FAN

Checked By: TRJ 
GRAIN SIZE DISTRIBUTION TEST DATA

8/4/2016

Project: Preston, IL

Location: MVN-PR-15-03

Depth: 9-10.5

Sample Number: 1

Material Description: Clay $(\mathrm{CH})$, Gray

Fines are classified visually.

Tested by: AT/FAN

Checked by: TRJ

\begin{tabular}{|c|c|c|c|c|c|}
\hline \multicolumn{6}{|c|}{ Sieve Test Data } \\
\hline $\begin{array}{c}\text { Dry } \\
\text { Sample } \\
\text { and Tare } \\
\text { (grams) }\end{array}$ & $\begin{array}{c}\text { Tare } \\
\text { (grams) }\end{array}$ & $\begin{array}{c}\text { Cumulative } \\
\text { Pan } \\
\text { Tare Weight } \\
\text { (grams) }\end{array}$ & $\begin{array}{c}\text { Sieve } \\
\text { Opening } \\
\text { Size }\end{array}$ & $\begin{array}{l}\text { Cumulative } \\
\text { Weight } \\
\text { Retained } \\
\text { (grams) }\end{array}$ & $\begin{array}{l}\text { Percent } \\
\text { Finer }\end{array}$ \\
\hline \multirow{10}{*}{57.50} & 0.00 & 0.00 & $\# 10$ & 0.00 & 100.0 \\
\hline & & & $\# 16$ & 0.10 & 99.8 \\
\hline & & & $\# 20$ & 0.10 & 99.8 \\
\hline & & & $\# 30$ & 0.10 & 99.8 \\
\hline & & & $\# 40$ & 0.10 & 99.8 \\
\hline & & & $\# 50$ & 0.10 & 99.8 \\
\hline & & & $\# 70$ & 0.10 & 99.8 \\
\hline & & & $\# 100$ & 0.20 & 99.7 \\
\hline & & & $\# 140$ & 0.30 & 99.5 \\
\hline & & & $\# 200$ & 0.50 & 99.1 \\
\hline
\end{tabular}

Hydrometer test uses material passing $\# 10$

Percent passing $\# 10$ based upon complete sam ple $=100.0$

Weight of hydrometer sample $=57.5$

Automatic temperature correction

Composite correction (fluid density and meniscus height) at 20 deg. $C=-4.7$

Meniscus correction only $=-0.5$

Specific gravity of solids $=2.70$ est

Hydrometer type $=151 \mathrm{H}$

Hydrometer effective depth equation: $L=16.294964-0.2645 \times \mathrm{Rm}$

\begin{tabular}{|c|c|c|c|c|c|c|c|c|}
\hline $\begin{array}{l}\text { Elapsed } \\
\text { Time (min.) }\end{array}$ & $\begin{array}{l}\text { Temp. } \\
\text { (deg. C.) }\end{array}$ & $\begin{array}{c}\text { Actual } \\
\text { Reading }\end{array}$ & $\begin{array}{l}\text { Corrected } \\
\text { Reading }\end{array}$ & $K$ & $\mathrm{Rm}$ & $\begin{array}{l}\text { Eff. } \\
\text { Depth }\end{array}$ & $\begin{array}{l}\text { Diameter } \\
(\mathrm{mm} .)\end{array}$ & $\begin{array}{l}\text { Percent } \\
\text { Finer }\end{array}$ \\
\hline 2.00 & 22.0 & 1.0250 & 1.0206 & 0.0131 & 24.5 & 9.8 & 0.0291 & 56.8 \\
\hline 5.00 & 22.0 & 1.0182 & 1.0138 & 0.0131 & 17.7 & 11.6 & 0.0200 & 38.0 \\
\hline 15.00 & 22.0 & 1.0111 & 1.0067 & 0.0131 & 10.6 & 13.5 & 0.0124 & 18.4 \\
\hline 30.00 & 22.0 & 1.0103 & 1.0059 & 0.0131 & 9.8 & 13.7 & 0.0089 & 16.2 \\
\hline 60.00 & 22.0 & 1.0100 & 1.0056 & 0.0131 & 9.5 & 13.8 & 0.0063 & 15.3 \\
\hline 120.00 & 22.0 & 1.0091 & 1.0047 & 0.0131 & 8.6 & 14.0 & 0.0045 & 12.8 \\
\hline 250.00 & 22.0 & 1.0089 & 1.0045 & 0.0131 & 8.4 & 14.1 & 0.0031 & 12.3 \\
\hline 1440.00 & 22.0 & 1.0079 & 1.0035 & 0.0131 & 7.4 & 14.3 & 0.0013 & 9.5 \\
\hline
\end{tabular}




\begin{tabular}{|c|c|c|c|c|c|c|c|c|c|c|}
\hline \multicolumn{11}{|c|}{ Fractional Components } \\
\hline \multirow{2}{*}{ Cobbles } & \multicolumn{3}{|c|}{ Gravel } & \multicolumn{4}{|c|}{ Sand } & \multicolumn{3}{|c|}{ Fines } \\
\hline & Coarse & Fine & Total & Coarse & Medium & Fine & Total & Silt & Clay & Total \\
\hline 0.0 & 0.0 & 0.0 & 0.0 & 0.0 & 0.2 & 0.7 & 0.9 & 85.5 & 13.6 & 99.1 \\
\hline
\end{tabular}

\begin{tabular}{|c|c|c|c|c|c|c|c|c|c|c|c|}
\hline $\mathbf{D}_{\mathbf{5}}$ & $\mathbf{D}_{\mathbf{1 0}}$ & $\mathbf{D}_{\mathbf{1 5}}$ & $\mathbf{D}_{\mathbf{2 0}}$ & $\mathbf{D}_{\mathbf{3 0}}$ & $\mathbf{D}_{\mathbf{4 0}}$ & $\mathbf{D}_{\mathbf{5 0}}$ & $\mathbf{D}_{\mathbf{6 0}}$ & $\mathbf{D}_{\mathbf{8 0}}$ & $\mathbf{D}_{\mathbf{8 5}}$ & $\mathbf{D}_{\mathbf{9 0}}$ & $\mathbf{D}_{\mathbf{9 5}}$ \\
\hline & 0.0015 & 0.0060 & 0.0133 & 0.0170 & 0.0208 & 0.0255 & 0.0308 & 0.0443 & 0.0489 & 0.0546 & 0.0625 \\
\hline
\end{tabular}

\begin{tabular}{|c|c|c|}
\hline $\begin{array}{c}\text { Fineness } \\
\text { Modulus }\end{array}$ & $\mathrm{c}_{\mathbf{u}}$ & $\mathrm{c}_{\mathbf{c}}$ \\
\hline 0.01 & 21.25 & 6.47 \\
\hline
\end{tabular}




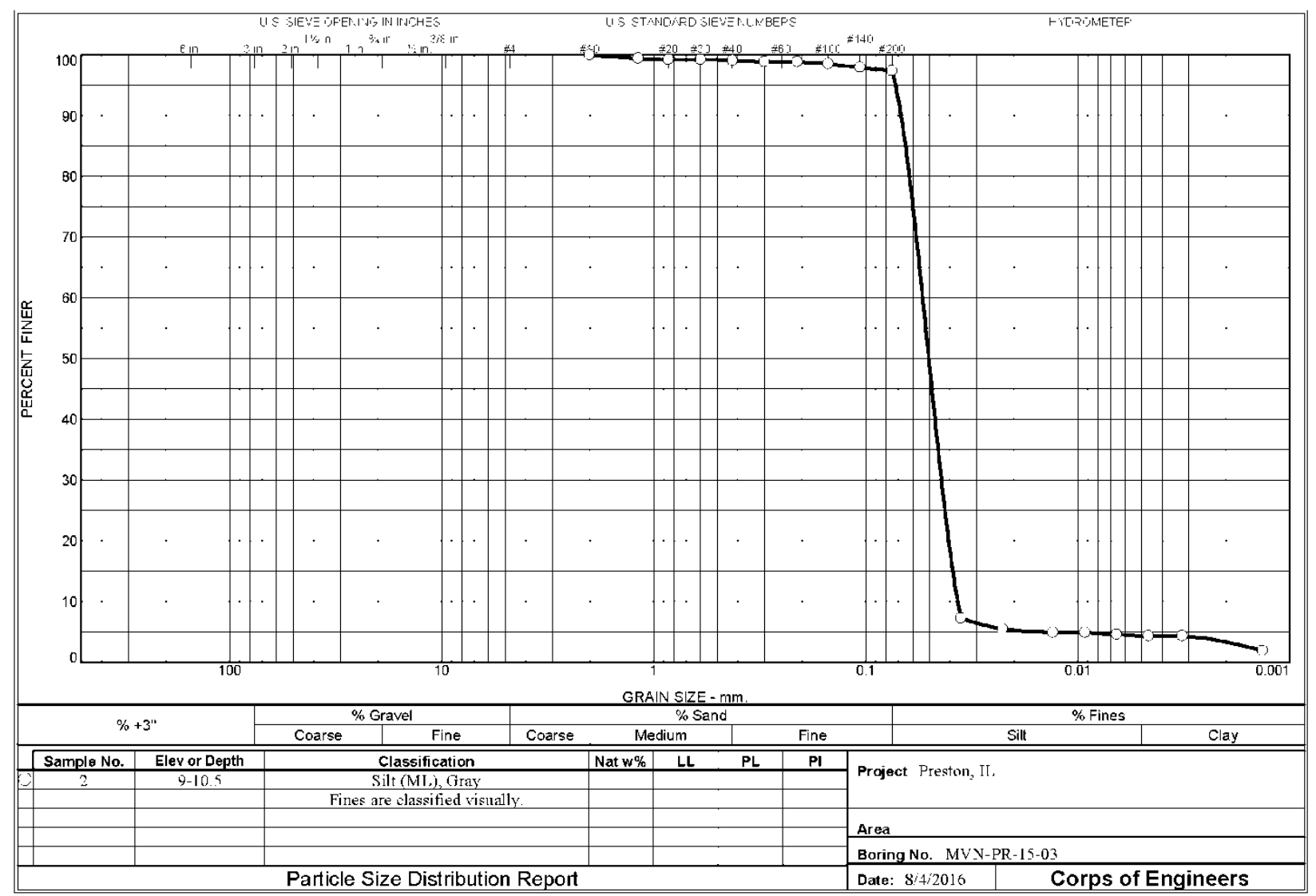

ENG 1 MORM 2087

Tested By: AT/FAN

Checked By: TRJ 
GRAIN SIZE DISTRIBUTION TEST DATA

8/4/2016

Project: Preston, IL

Location: MVN-PR-15-03

Depth: 9-10.5

Sample Number: 2

Material Description: Silt (ML), Gray

Tested by: AT/FAN

Fines are classified visually.

\begin{tabular}{|c|c|c|c|c|c|c|c|c|}
\hline Tested by: A & FAN & & & & Checked $\mathrm{b}$ & गy: TRJ & & \\
\hline & & & & Sieve Tes & est Data & & & \\
\hline $\begin{array}{c}\text { Dry } \\
\text { Sample } \\
\text { and Tare } \\
\text { (grams) }\end{array}$ & $\begin{array}{c}\text { Tare } \\
\text { (grams) }\end{array}$ & $\begin{array}{l}\text { Cumulative } \\
\text { Pan } \\
\text { Tare Weight } \\
\text { (grams) }\end{array}$ & $\begin{array}{l}\mathrm{Sie} \\
\text { Ope } \\
\mathrm{Si}\end{array}$ & & $\begin{array}{l}\text { Dumulative } \\
\text { Weight } \\
\text { Retained } \\
\text { (grams) }\end{array}$ & $\begin{array}{c}\text { Percent } \\
\text { Finer }\end{array}$ & & \\
\hline 53.60 & 0.00 & 0.00 & & 10 & 0.00 & 100.0 & & \\
\hline & & & & 16 & 0.30 & 99.4 & & \\
\hline & & & & 20 & 0.40 & 99.3 & & \\
\hline & & & & $\$ 30$ & 0.40 & 99.3 & & \\
\hline & & & & 40 & 0.50 & 99.1 & & \\
\hline & & & & 550 & 0.60 & 98.9 & & \\
\hline & & & & 70 & 0.60 & 98.9 & & \\
\hline & & & & 00 & 0.80 & 98.5 & & \\
\hline & & & & 40 & 1.10 & 97.9 & & \\
\hline & & & & 200 & 1.40 & 97.4 & & \\
\hline & & & & Irometer & I Test Dat & & & \\
\hline $\begin{array}{l}\text { Hydrometer te } \\
\text { Percent passi } \\
\text { Weight of hyd } \\
\text { Automatic tem } \\
\text { Composite } \\
\text { Meniscus corr } \\
\text { Specific gravi } \\
\text { Hydrometer ty } \\
\text { Hydrometer }\end{array}$ & $\begin{array}{l}\text { t uses mate } \\
\text { g \#10 based } \\
\text { meter samp } \\
\text { erature cor } \\
\text { orrection (fl } \\
\text { ction only = } \\
\text { of solids = } \\
e=151 \mathrm{H} \\
\text { ffective dep }\end{array}$ & $\begin{array}{l}\text { al passing } \# 1 \\
\text { upon complete } \\
e=53.6 \\
\text { ection } \\
\text { id density and } \\
0.5 \\
.69 \text { est } \\
\text { h equation: L }\end{array}$ & $\begin{array}{l}\text { e sample }=1 \\
\text { meniscus h } \\
=16.294964\end{array}$ & $\begin{array}{l}0.0 \\
0.2645 \times\end{array}$ & $\begin{array}{l}20 \mathrm{deg} . \mathrm{C}= \\
\times \mathrm{Rm}\end{array}$ & -4.7 & & \\
\hline $\begin{array}{c}\text { Elapsed } \\
\text { Time (min.) }\end{array}$ & $\begin{array}{l}\text { Temp. } \\
\text { (deg. C.) }\end{array}$ & $\begin{array}{l}\text { Actual } \\
\text { Reading }\end{array}$ & $\begin{array}{l}\text { Corrected } \\
\text { Reading }\end{array}$ & K & Rm & $\begin{array}{c}\text { Eff. } \\
\text { Depth }\end{array}$ & $\begin{array}{l}\text { Diameter } \\
(\mathrm{mm} .)\end{array}$ & $\begin{array}{l}\text { Percent } \\
\text { Finer }\end{array}$ \\
\hline 2.00 & 22.0 & 1.0069 & 1.0025 & 0.0132 & 6.4 & 14.6 & 0.0355 & 7.3 \\
\hline 5.00 & 22.0 & 1.0063 & 1.0019 & 0.0132 & 5.8 & 14.8 & 0.0226 & 5.5 \\
\hline 15.00 & 22.0 & 1.0061 & 1.0017 & 0.0132 & 5.6 & 14.8 & 0.0131 & 4.9 \\
\hline 30.00 & 22.0 & 1.0061 & 1.0017 & 0.0132 & 5.6 & 14.8 & 0.0092 & 4.9 \\
\hline 60.00 & 22.0 & 1.0060 & 1.0016 & 0.0132 & 5.5 & 14.8 & 0.0065 & 4.6 \\
\hline 120.00 & 22.0 & 1.0059 & 1.0015 & 0.0132 & 5.4 & 14.9 & 0.0046 & 4.3 \\
\hline 250.00 & 22.0 & 1.0059 & 1.0015 & 0.0132 & 5.4 & 14.9 & 0.0032 & 4.3 \\
\hline 1440.00 & 22.0 & 1.0051 & 1.0007 & 0.0132 & 4.6 & 15.1 & 0.0013 & 1.9 \\
\hline
\end{tabular}




\begin{tabular}{|c|c|c|c|c|c|c|c|c|c|c|c|c|}
\hline \multicolumn{13}{|c|}{ Fractional Components } \\
\hline \multirow{2}{*}{ Cobbles } & \multicolumn{3}{|c|}{ Gravel } & \multicolumn{6}{|c|}{ Sand } & \multicolumn{3}{|c|}{ Fines } \\
\hline & Coarse & Fine & Total & \multicolumn{2}{|c|}{ Coarse } & \multicolumn{2}{|c|}{ Medium } & Fine & Total & \multicolumn{2}{|r|}{ Clay } & Total \\
\hline 0.0 & 0.0 & 0.0 & 0.0 & 0.0 & & 0.9 & & 1.7 & 2.6 & 93.1 & 4.3 & 97.4 \\
\hline$D_{5}$ & $\mathrm{D}_{10}$ & $\mathrm{D}_{15}$ & $\mathrm{D}_{20}$ & $\mathrm{D}_{30}$ & $\mathrm{D}_{4}$ & & $\mathrm{D}_{50}$ & $\mathrm{D}_{\mathrm{C}}$ & $\mathrm{D}_{80}$ & $D_{85}$ & $\mathrm{D}_{90}$ & $\mathrm{D}_{95}$ \\
\hline 0.0153 & 0.0369 & 0.0389 & 0.0407 & 0.0440 & 0.04 & & 0.050 & 0.0 & 0.0622 & 0.0648 & 0.0680 & 0.0722 \\
\hline
\end{tabular}

\begin{tabular}{|c|c|c|}
\hline $\begin{array}{l}\text { Fineness } \\
\text { Modulus }\end{array}$ & $\mathrm{c}_{\mathrm{u}}$ & $\mathrm{c}_{\mathrm{c}}$ \\
\hline 0.04 & 1.46 & 0.97 \\
\hline
\end{tabular}




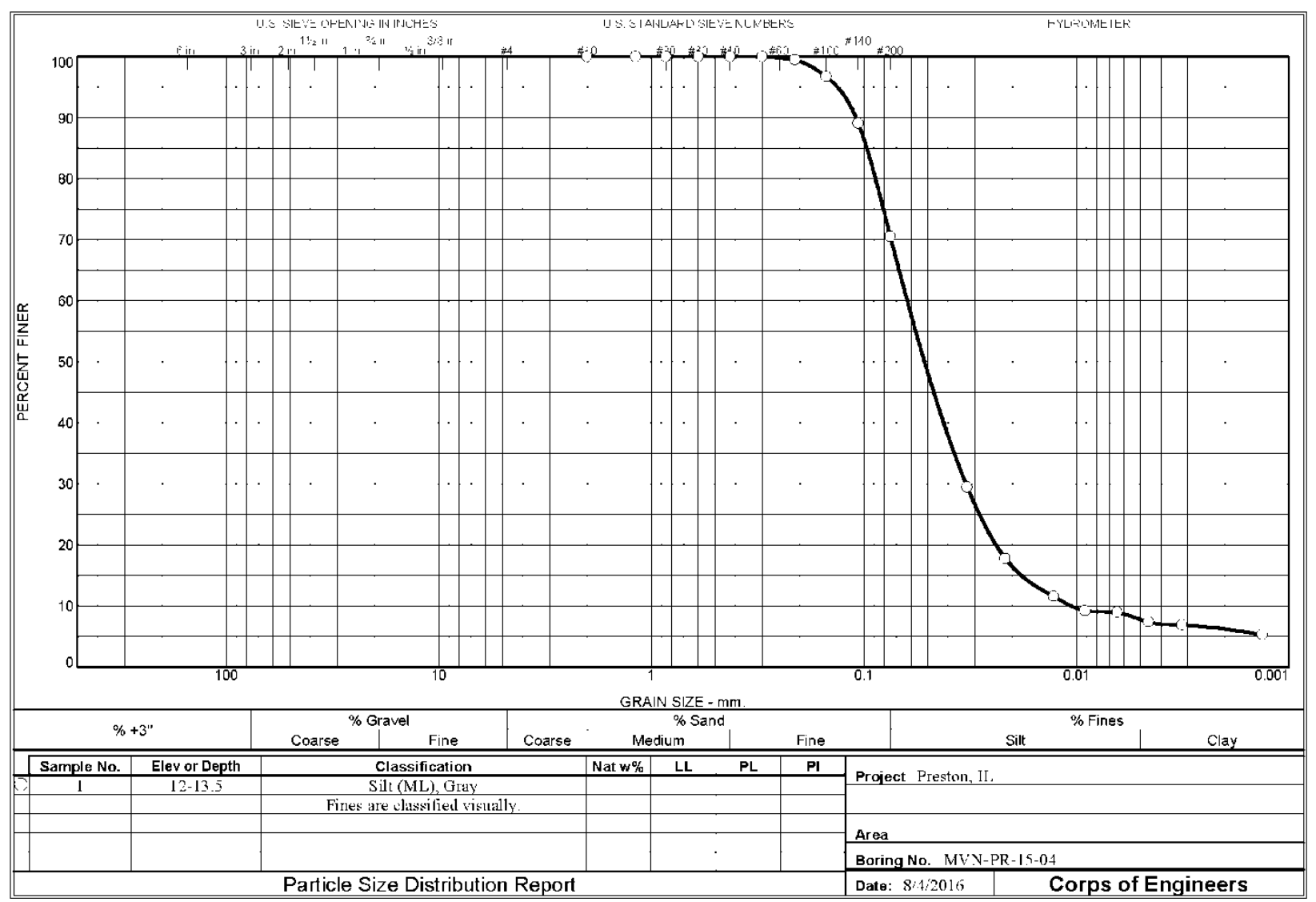

ENG 1 FORM 2087

Tested By: AT/FAN

Checked By: TRJ 
Project: Preston, IL

Location: MVN-PR-15-04

Depth: $12-13.5$

Sample Number: 1

Material Description: Silt (ML), Gray

Tested by: AT/FAN

Fines are classified visually.

\begin{tabular}{|c|c|c|c|c|c|c|c|c|}
\hline & & & & & - & . 1hu & & \\
\hline & & & & Sieve Te: & est Data & & & \\
\hline $\begin{array}{c}\text { Dry } \\
\text { Sample } \\
\text { and Tare } \\
\text { (grams) }\end{array}$ & $\begin{array}{c}\text { Tare } \\
\text { (grams) }\end{array}$ & $\begin{array}{c}\text { Cumulative } \\
\text { Pan } \\
\text { Tare Weight } \\
\text { (grams) }\end{array}$ & $\begin{array}{c}\mathrm{Sie} \\
\text { Oper } \\
\mathrm{Si}^{2}\end{array}$ & & $\begin{array}{l}\text { umulative } \\
\text { Weight } \\
\text { Retained } \\
\text { (grams) }\end{array}$ & $\begin{array}{l}\text { Percent } \\
\text { Finer }\end{array}$ & & \\
\hline 61.40 & 0.00 & 0.00 & & $\$ 10$ & 0.00 & 100.0 & & \\
\hline & & & & $\# 16$ & 0.00 & 100.0 & & \\
\hline & & & & $\$ 20$ & 0.00 & 100.0 & & \\
\hline & & & & 430 & 0.00 & 100.0 & & \\
\hline & & & & $\# 40$ & 0.00 & 100.0 & & \\
\hline & & & & 450 & 0.00 & 100.0 & & \\
\hline & & & & 470 & 0.30 & 99.5 & & \\
\hline & & & & 100 & 2.00 & 96.7 & & \\
\hline & & & & 140 & 6.70 & 89.1 & & \\
\hline & & & & 200 & 18.10 & 70.5 & & \\
\hline & & & & drometer & r Test Dat & & & \\
\hline $\begin{array}{l}\text { Hydrometer te } \\
\text { Percent passir } \\
\text { Weight of hyd } \\
\text { Automatic tem } \\
\text { Composite } \\
\text { Meniscus corr } \\
\text { Specific gravit } \\
\text { Hydrometer ty } \\
\text { Hydrometer }\end{array}$ & $\begin{array}{l}t \text { uses mate } \\
\# 10 \text { based } \\
\text { meter sam } \\
\text { erature cor } \\
\text { rrection (fl } \\
\text { ction only } \\
\text { of solids = } \\
e=151 \mathrm{H} \\
\text { ffective de }\end{array}$ & $\begin{array}{l}\text { al passing } \# 1 \\
\text { upon complet } \\
\mathbf{e}=61.4 \\
\text { ction } \\
\text { id density and } \\
0.5 \\
69 \text { est } \\
\text { h equation: L }\end{array}$ & $\begin{array}{l}\text { meniscus h } \\
=16.294964\end{array}$ & $\begin{array}{l}0.0 \\
-0.2645 \times\end{array}$ & $\begin{array}{l}0 \mathrm{deg} . \mathrm{C}= \\
\times \mathrm{Rm}\end{array}$ & & & \\
\hline $\begin{array}{l}\text { Elapsed } \\
\text { Time (min.) }\end{array}$ & $\begin{array}{l}\text { Temp. } \\
\text { (deg. C.) }\end{array}$ & $\begin{array}{c}\text { Actual } \\
\text { Reading }\end{array}$ & $\begin{array}{l}\text { Corrected } \\
\text { Reading }\end{array}$ & $\mathrm{K}$ & $\mathrm{Rm}$ & $\begin{array}{c}\text { Eff. } \\
\text { Depth }\end{array}$ & $\begin{array}{c}\text { Diameter } \\
(\mathrm{mm} .)\end{array}$ & $\begin{array}{l}\text { Percent } \\
\text { Finer }\end{array}$ \\
\hline 2.00 & 22.0 & 1.0158 & 1.0114 & 0.0132 & 15.3 & 12.2 & 0.0326 & 29.4 \\
\hline 5.00 & 22.0 & 1.0113 & 1.0069 & 0.0132 & 10.8 & 13.4 & 0.0216 & 17.8 \\
\hline 15.00 & 22.0 & 1.0089 & 1.0045 & 0.0132 & 8.4 & 14.1 & 0.0127 & 11.5 \\
\hline 30.00 & 22.0 & 1.0080 & 1.0036 & 0.0132 & 7.5 & 14.3 & 0.0091 & 9.2 \\
\hline 60.00 & 22.0 & 1.0079 & 1.0035 & 0.0132 & 7.4 & 14.3 & 0.0064 & 8.9 \\
\hline 120.00 & 22.0 & 1.0073 & 1.0029 & 0.0132 & 6.8 & 14.5 & 0.0046 & 7.4 \\
\hline 250.00 & 22.0 & 1.0071 & 1.0027 & 0.0132 & 6.6 & 14.5 & 0.0032 & 6.9 \\
\hline 1440.00 & 22.0 & 1.0065 & 1.0021 & 0.0132 & 6.0 & 14.7 & 0.0013 & 5.3 \\
\hline
\end{tabular}




\begin{tabular}{|c|c|c|c|c|c|c|c|c|c|c|}
\hline \multirow{3}{*}{ Cobbles } & \multicolumn{10}{|c|}{ Fractional Components } \\
\hline & \multicolumn{3}{|c|}{ Gravel } & \multicolumn{4}{|c|}{ Sand } & \multicolumn{3}{|c|}{ Fines } \\
\hline & Coarse & Fine & Total & Coarse & Medium & Fine & Total & Silt & Clay & Total \\
\hline 0.0 & 0.0 & 0.0 & 0.0 & 0.0 & 0.0 & 29.5 & 29.5 & 62.7 & 7.8 & 70.5 \\
\hline
\end{tabular}

\begin{tabular}{|c|c|c|c|c|c|c|c|c|c|c|c|}
\hline $\mathrm{D}_{\mathbf{5}}$ & $\mathrm{D}_{\mathbf{1 0}}$ & $\mathrm{D}_{\mathbf{1 5}}$ & $\mathrm{D}_{\mathbf{2 0}}$ & $\mathrm{D}_{\mathbf{3 0}}$ & $\mathbf{D}_{\mathbf{4 0}}$ & $\mathrm{D}_{\mathbf{5 0}}$ & $\mathrm{D}_{\mathbf{6 0}}$ & $\mathrm{D}_{\mathbf{8 0}}$ & $\mathrm{D}_{\mathbf{8 5}}$ & $\mathrm{D}_{\mathbf{9 0}}$ & $\mathrm{D}_{\mathbf{9 5}}$ \\
\hline & 0.0105 & 0.0182 & 0.0239 & 0.0331 & 0.0421 & 0.0518 & 0.0625 & 0.0881 & 0.0967 & 0.1086 & 0.1324 \\
\hline
\end{tabular}

\begin{tabular}{|c|c|c|}
\hline $\begin{array}{c}\text { Fineness } \\
\text { Modulus }\end{array}$ & $\mathrm{c}_{\mathrm{u}}$ & $\mathrm{c}_{\mathrm{c}}$ \\
\hline 0.03 & 5.92 & 1.66 \\
\hline
\end{tabular}




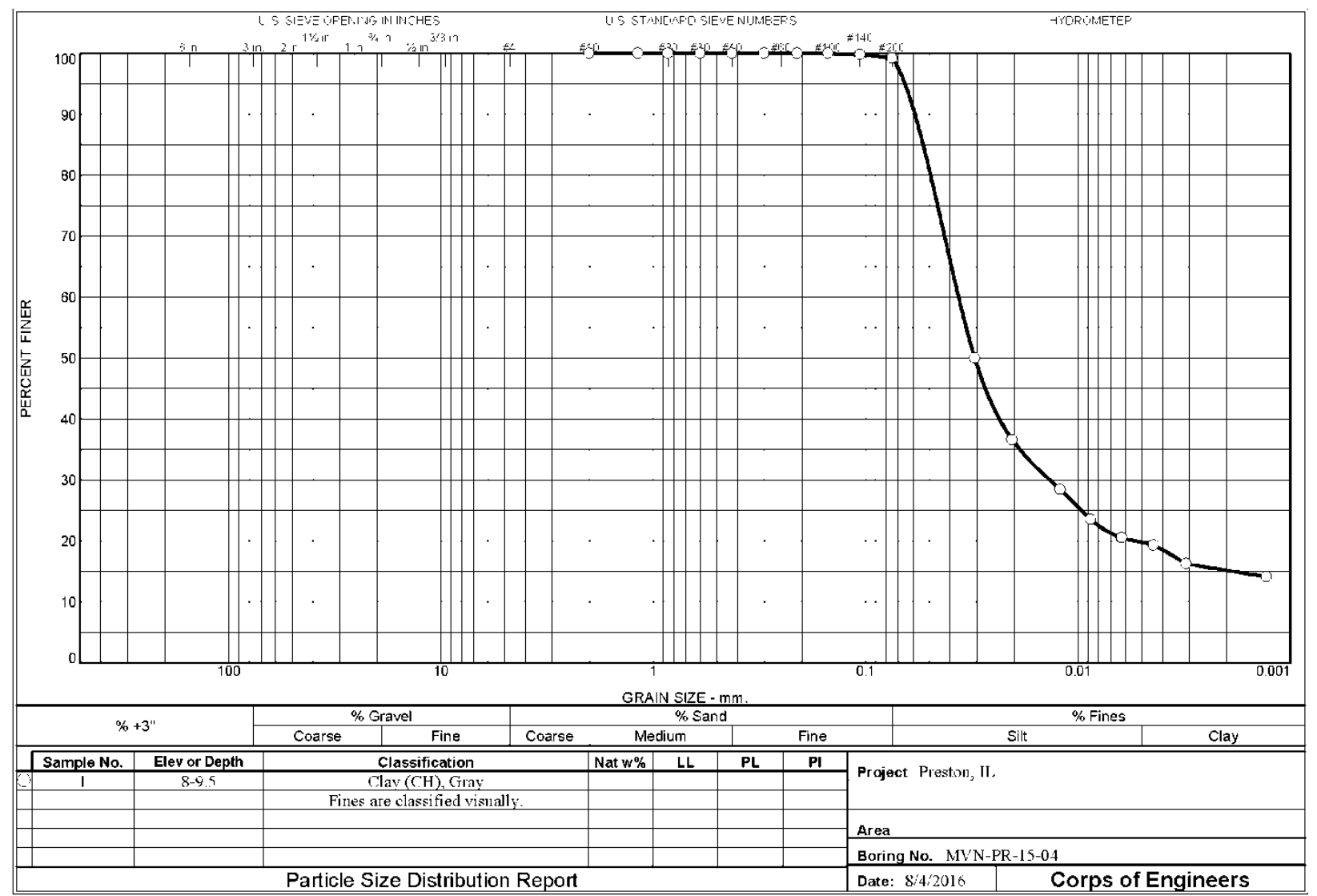

ENG 1 FORM 2087

Tested By: AT/FAN

Checked By: TRJ 
Project: Preston, IL

Location: MVN-PR-15-04

Depth: 8-9.5

Sample Number: 1

Material Description: Clay (CH), Gray

Tested by: AT/FAN

Fines are classified visually.

\begin{tabular}{|c|c|c|c|c|c|}
\hline Tested by: & & & & Checked & : TRJ \\
\hline & & & Sie & Test Data & \\
\hline $\begin{array}{c}\text { Dry } \\
\text { Sample } \\
\text { and Tare } \\
\text { (grams) }\end{array}$ & $\begin{array}{c}\text { Tare } \\
\text { (grams) }\end{array}$ & $\begin{array}{c}\text { Cumulative } \\
\text { Pan } \\
\text { Tare Weight } \\
\text { (grams) }\end{array}$ & $\begin{array}{c}\text { Sieve } \\
\text { Opening } \\
\text { Size }\end{array}$ & $\begin{array}{c}\text { Cumulative } \\
\text { Weight } \\
\text { Retained } \\
\text { (grams) }\end{array}$ & $\begin{array}{l}\text { Percent } \\
\text { Finer }\end{array}$ \\
\hline 52.30 & 0.00 & 0.00 & $\# 10$ & 0.00 & 100.0 \\
\hline & & & $\# 16$ & 0.00 & 100.0 \\
\hline & & & $\# 20$ & 0.00 & 100.0 \\
\hline & & & $\# 30$ & 0.00 & 100.0 \\
\hline & & & $\# 40$ & 0.00 & 100.0 \\
\hline & & & $\# 50$ & 0.00 & 100.0 \\
\hline & & & $\# 70$ & 0.00 & 100.0 \\
\hline & & & $\# 100$ & 0.00 & 100.0 \\
\hline & & & $\# 140$ & 0.10 & 99.8 \\
\hline & & & $\# 200$ & 0.40 & 99.2 \\
\hline
\end{tabular}

Hydrometer test uses material passing $\# 10$

Hydrometer Test Data

Percent passing $\# 10$ based upon complete sample $=100.0$

Weight of hydrometer sample $=52.3$

Automatic temperature correction

Composite correction (fluid density and meniscus height) at $\mathbf{2 0}$ deg. $\mathrm{C}=-4.7$

Meniscus correction only $=-0.5$

Specific gravity of solids $=2.70$ est

Hydrometer type $=151 \mathrm{H}$

Hydrometer effective depth equation: $L=16.294964-0.2645 \times \mathbf{~ R m}$

$\begin{array}{ccccccccc}\begin{array}{c}\text { Elapsed } \\ \text { Time (min.) }\end{array} & \begin{array}{c}\text { Temp. } \\ \text { (deg. C.) }\end{array} & \begin{array}{c}\text { Actual } \\ \text { Reading }\end{array} & \begin{array}{c}\text { Corrected } \\ \text { Reading }\end{array} & \mathbf{K} & \mathbf{R m} & \begin{array}{c}\text { Eff. } \\ \text { Depth }\end{array} & \begin{array}{c}\text { Diameter } \\ \text { (mm.) }\end{array} & \begin{array}{c}\text { Percent } \\ \text { Finer }\end{array} \\ 2.00 & 22.0 & 1.0209 & 1.0165 & 0.0131 & 20.4 & 10.9 & 0.0306 & 50.0 \\ 5.00 & 22.0 & 1.0165 & 1.0121 & 0.0131 & 16.0 & 12.1 & 0.0204 & 36.6 \\ 15.00 & 22.0 & 1.0138 & 1.0094 & 0.0131 & 13.3 & 12.8 & 0.0121 & 28.4 \\ 30.00 & 22.0 & 1.0122 & 1.0078 & 0.0131 & 11.7 & 13.2 & 0.0087 & 23.5 \\ 60.00 & 22.0 & 1.0112 & 1.0068 & 0.0131 & 10.7 & 13.5 & 0.0062 & 20.5 \\ 120.00 & 22.0 & 1.0108 & 1.0064 & 0.0131 & 10.3 & 13.6 & 0.0044 & 19.3 \\ 250.00 & 22.0 & 1.0098 & 1.0054 & 0.0131 & 9.3 & 13.8 & 0.0031 & 16.3 \\ 1440.00 & 22.0 & 1.0091 & 1.0047 & 0.0131 & 8.6 & 14.0 & 0.0013 & 14.1\end{array}$




\begin{tabular}{|c|c|c|c|c|c|c|c|c|c|c|c|c|}
\hline \multicolumn{13}{|c|}{ Fractional Components } \\
\hline \multirow{2}{*}{ Cobbles } & \multicolumn{3}{|c|}{ Gravel } & \multicolumn{6}{|c|}{ Sand } & \multicolumn{3}{|c|}{ Fines } \\
\hline & Coarse & Fine & Total & \multicolumn{2}{|c|}{ Coarse } & \multicolumn{2}{|c|}{ Medium } & Fine & Total & \multicolumn{2}{|r|}{ Clay } & Total \\
\hline 0.0 & 0.0 & 0.0 & 0.0 & 0.0 & & 0. & & 0.8 & 0.8 & 79.4 & 19.8 & 99.2 \\
\hline \multirow[t]{2}{*}{$D_{5}$} & $D_{10}$ & $\mathrm{D}_{15}$ & $\mathrm{D}_{20}$ & $\mathrm{D}_{30}$ & $\mathrm{D}_{4}$ & & $\mathrm{D}_{50}$ & $\mathrm{D}_{\mathrm{C}}$ & $\mathrm{D}_{80}$ & $D_{85}$ & $\mathrm{D}_{90}$ & $\mathrm{D}_{95}$ \\
\hline & & 0.0018 & 0.0054 & 0.0135 & 0.02 & & 0.030 & 0.0 & 0.0494 & 0.0536 & 0.0586 & 0.0652 \\
\hline
\end{tabular}

Fineness

Modulus

0.00 


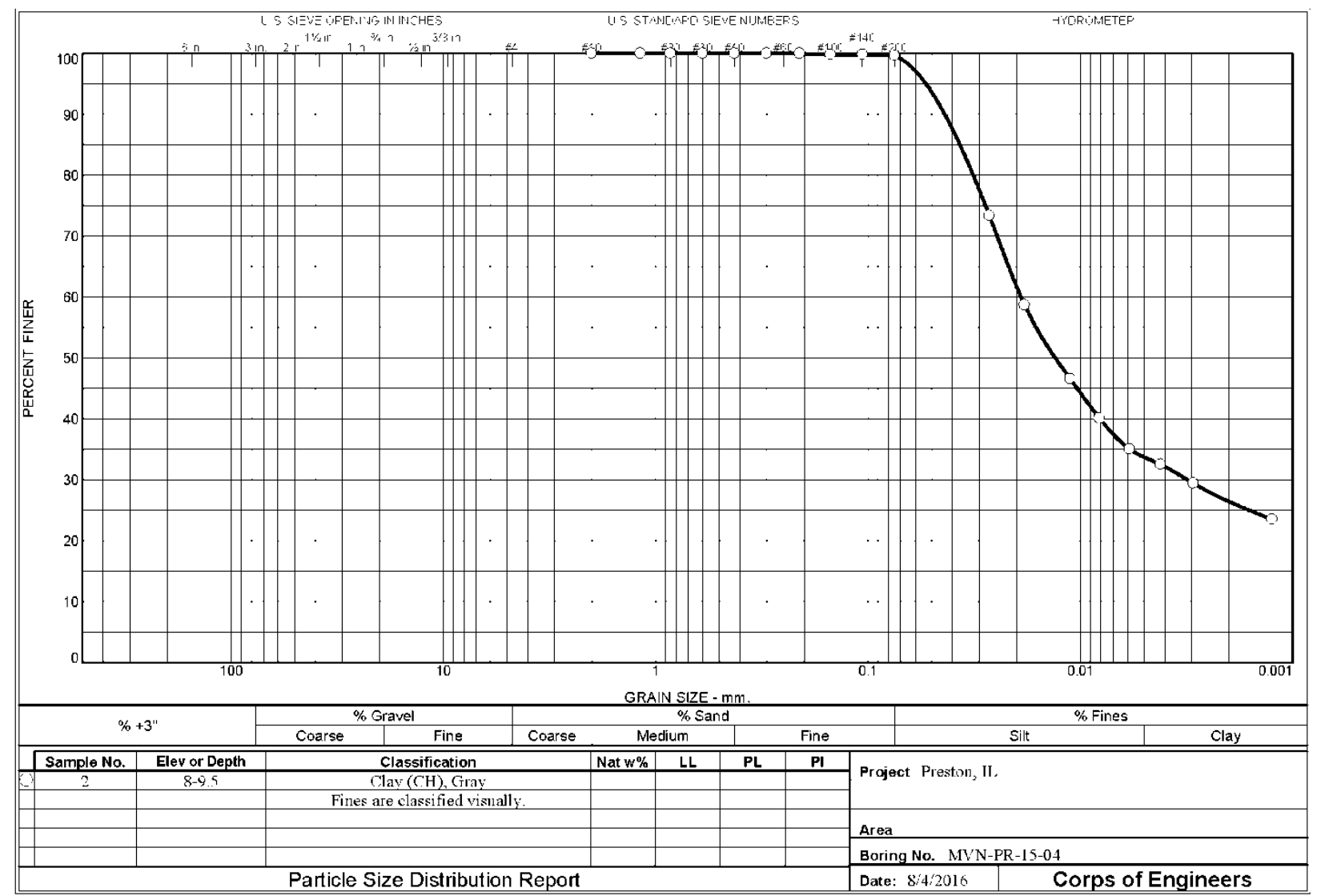

ENG 1 FORM 2087

Tested By: AAT/FAN

Checked By: TRJ 
GRAIN SIZE DISTRIBUTION TEST DATA

Project: Preston, IL

Location: MVN-PR-15-04

Depth: 8-9.5

Sample Number: 2

Material Description: Clay (CH), Gray

Fines are classified visually.

Tested by: AAT/FAN

Checked by: TRJ

\begin{tabular}{|c|c|c|c|c|c|}
\hline & & & Sie & Test Data & \\
\hline $\begin{array}{c}\text { Dry } \\
\text { Sample } \\
\text { and Tare } \\
\text { (grams) }\end{array}$ & $\begin{array}{c}\text { Tare } \\
\text { (grams) }\end{array}$ & $\begin{array}{l}\text { Cumulative } \\
\text { Pan } \\
\text { Tare Weight } \\
\text { (grams) }\end{array}$ & $\begin{array}{c}\text { Sieve } \\
\text { Opening } \\
\text { Size }\end{array}$ & $\begin{array}{c}\text { Cumulative } \\
\text { Weight } \\
\text { Retained } \\
\text { (grams) }\end{array}$ & $\begin{array}{l}\text { Percent } \\
\text { Finer }\end{array}$ \\
\hline 56.40 & 0.00 & 0.00 & $\# 10$ & 0.00 & 100.0 \\
\hline & & & $\# 16$ & 0.00 & 100.0 \\
\hline & & & $\# 20$ & 0.00 & 100.0 \\
\hline & & & $\# 30$ & 0.00 & 100.0 \\
\hline & & & $\# 40$ & 0.00 & 100.0 \\
\hline & & & $\# 50$ & 0.00 & 100.0 \\
\hline & & & $\# 70$ & 0.00 & 100.0 \\
\hline & & & $\# 100$ & 0.10 & 99.8 \\
\hline & & & $\# 140$ & 0.10 & 99.8 \\
\hline & & & $\# 200$ & 0.20 & 99.6 \\
\hline
\end{tabular}

Hydrometer test uses material passing \#1 0

Hydrometer Test Data

Percent passing $\# 10$ based upon complete sample $=100.0$

Weight of hydrometer sample $=56.4$

Automatic temperature correction

Composite correction (fluid density and meniscus height) at $\mathbf{2 0}$ deg. $C=-4.7$

Meniscus correction only $=-0.5$

Specific gravity of solids $=2.70$ est

Hydrometer type $=151 \mathrm{H}$

Hydrometer effective depth equation: $L=16.294964-0.2645 \times \mathbf{R m}$

$\begin{array}{ccccccccc}\begin{array}{c}\text { Elapsed } \\ \text { Time (min.) }\end{array} & \begin{array}{c}\text { Temp. } \\ \text { (deg. C.) }\end{array} & \begin{array}{c}\text { Actual } \\ \text { Reading }\end{array} & \begin{array}{c}\text { Corrected } \\ \text { Reading }\end{array} & \text { K } & \text { Rm } & \begin{array}{c}\text { Eff. } \\ \text { Depth }\end{array} & \begin{array}{c}\text { Diameter } \\ \text { (mm.) }\end{array} & \begin{array}{c}\text { Percent } \\ \text { Finer }\end{array} \\ 2.00 & 22.0 & 1.0305 & 1.0261 & 0.0131 & 30.0 & 8.4 & 0.0268 & 73.4 \\ 5.00 & 22.0 & 1.0253 & 1.0209 & 0.0131 & 24.8 & 9.7 & 0.0183 & 58.7 \\ 15.00 & 22.0 & 1.0210 & 1.0166 & 0.0131 & 20.5 & 10.9 & 0.0112 & 46.6 \\ 30.00 & 22.0 & 1.0187 & 1.0143 & 0.0131 & 18.2 & 11.5 & 0.0081 & 40.1 \\ 60.00 & 22.0 & 1.0169 & 1.0125 & 0.0131 & 16.4 & 12.0 & 0.0059 & 35.1 \\ 120.00 & 22.0 & 1.0160 & 1.0116 & 0.0131 & 15.5 & 12.2 & 0.0042 & 32.5 \\ 250.00 & 22.0 & 1.0149 & 1.0105 & 0.0131 & 14.4 & 12.5 & 0.0029 & 29.4 \\ 1440.00 & 22.0 & 1.0128 & 1.0084 & 0.0131 & 12.3 & 13.0 & 0.0012 & 23.5\end{array}$




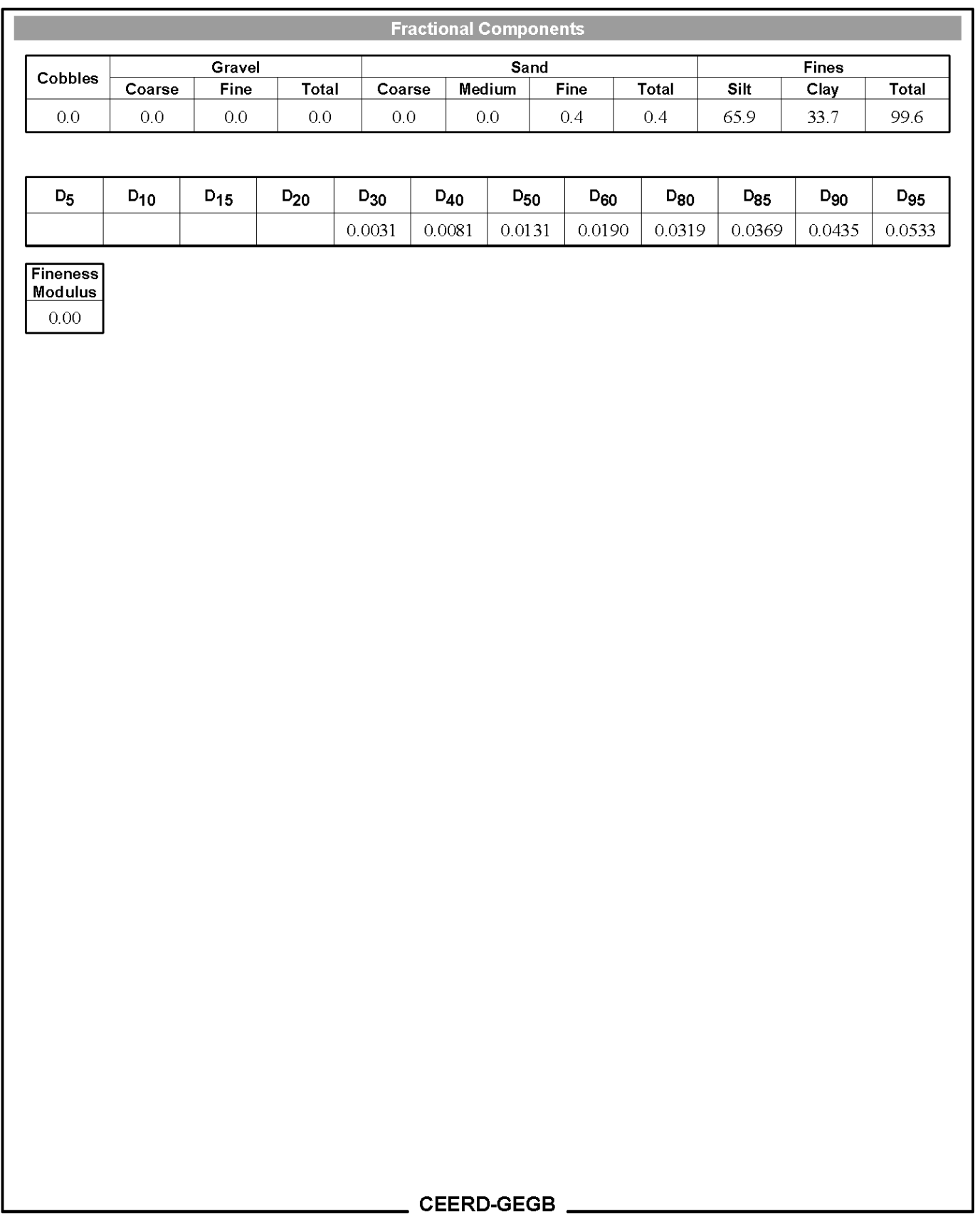




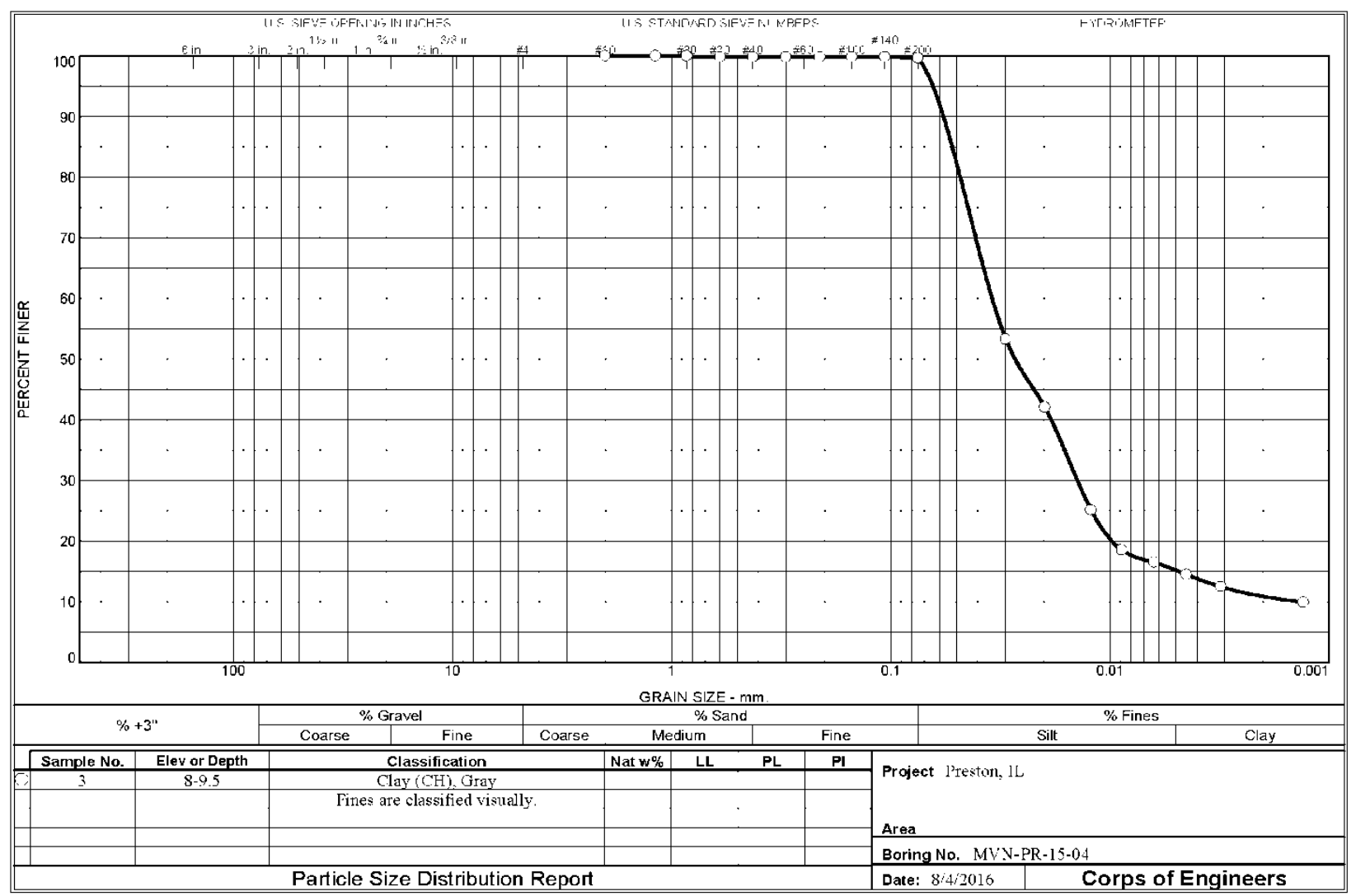

ENG $\begin{gathered}\text { FORM } \\ \text { MAY } 63\end{gathered} 2087$

Tested By: AT/FAN

Checked By: IRJ 
Project: Preston, IL

Location: MVN-PR-15-04

Depth: 8-9.5

Sample Number: 3

Material Description: Clay (CH), Gray

Fines are classified visually.

Tested by: AT/FAN

Checked by: TRJ

\begin{tabular}{|c|c|c|c|c|c|c|c|c|}
\hline \multirow{2}{*}{$\begin{array}{c}\text { Dry } \\
\text { Sample } \\
\text { and Tare } \\
\text { (grams) }\end{array}$} & \multicolumn{8}{|c|}{ Sieve Test Data } \\
\hline & $\begin{array}{c}\text { Tare } \\
\text { (grams) }\end{array}$ & $\begin{array}{c}\text { Cumulative } \\
\text { Pan } \\
\text { Tare Weight } \\
\text { (grams) }\end{array}$ & \multicolumn{2}{|c|}{$\begin{array}{c}\text { Sieve } \\
\text { Opening } \\
\text { Size }\end{array}$} & $\begin{array}{l}\text { umulative } \\
\text { Weight } \\
\text { Retained } \\
\text { (grams) }\end{array}$ & \multicolumn{2}{|c|}{$\begin{array}{l}\text { Percent } \\
\text { Finer }\end{array}$} & \\
\hline 55.30 & 0.00 & 0.00 & & $\begin{array}{l}10 \\
\$ 16 \\
20 \\
\$ 30 \\
\$ 40 \\
\$ 50 \\
70 \\
00 \\
40 \\
00\end{array}$ & $\begin{array}{l}0.00 \\
0.00 \\
0.00 \\
0.10 \\
0.10 \\
0.10 \\
0.10 \\
0.10 \\
0.10 \\
0.20\end{array}$ & $\begin{array}{r}100.0 \\
100.0 \\
100.0 \\
99.8 \\
99.8 \\
99.8 \\
99.8 \\
99.8 \\
99.8 \\
99.6\end{array}$ & & \\
\hline \multicolumn{9}{|c|}{$\begin{array}{l}\text { Hydrometer test uses material passing } \# 10 \\
\text { Percent passing } \# 10 \text { based upon complete sample }=100.0 \\
\text { Weight of hydrom eter sample }=55.3 \\
\text { Automatic temperature correction } \\
\text { Composite correction (fluid density and meniscus height) at } 20 \text { deg. } C=-4.7 \\
\text { Meniscus correction only }=-0.5 \\
\text { Specific gravity of solids }=2.70 \mathrm{est} \\
\text { Hydrometer type }=151 \mathrm{H} \\
\text { Hydrometer effective depth equation: } \mathrm{L}=16.294964-0.2645 \times \mathrm{Rm}\end{array}$} \\
\hline $\begin{array}{c}\text { Elapsed } \\
\text { Time (min.) }\end{array}$ & $\begin{array}{l}\text { Temp. } \\
\text { (deg. C.) }\end{array}$ & $\begin{array}{c}\text { Actual } \\
\text { Reading }\end{array}$ & $\begin{array}{l}\text { Corrected } \\
\text { Reading }\end{array}$ & $\mathrm{K}$ & $\mathbf{R m}$ & $\begin{array}{l}\text { Eff. } \\
\text { Depth }\end{array}$ & $\begin{array}{l}\text { Diameter } \\
(\mathbf{m m} .)\end{array}$ & $\begin{array}{l}\text { Percent } \\
\text { Finer }\end{array}$ \\
\hline 2.00 & 22.0 & 1.0230 & 1.0186 & 0.0131 & 22.5 & 10.3 & 0.0298 & 53.3 \\
\hline 5.00 & 22.0 & 1.0191 & 1.0147 & 0.0131 & 18.6 & 11.4 & 0.0198 & 42.1 \\
\hline 15.00 & 22.0 & 1.0132 & 1.0088 & 0.0131 & 12.7 & 12.9 & 0.0122 & 25.1 \\
\hline 30.00 & 22.0 & 1.0109 & 1.0065 & 0.0131 & 10.4 & 13.5 & 0.0088 & 18.5 \\
\hline 60.00 & 22.0 & 1.0102 & 1.0058 & 0.0131 & 9.7 & 13.7 & 0.0063 & 16.5 \\
\hline 120.00 & 22.0 & 1.0095 & 1.0051 & 0.0131 & 9.0 & 13.9 & 0.0045 & 14.5 \\
\hline 250.00 & 22.0 & 1.0088 & 1.0044 & 0.0131 & 8.3 & 14.1 & 0.0031 & 12.5 \\
\hline 1440.00 & 22.0 & 1.0079 & 1.0035 & 0.0131 & 7.4 & 14.3 & 0.0013 & 9.9 \\
\hline
\end{tabular}




\begin{tabular}{|c|c|c|c|c|c|c|c|c|c|c|c|c|c|}
\hline \multicolumn{14}{|c|}{ Fractional Components } \\
\hline \multirow{2}{*}{ Cobbles } & \multicolumn{3}{|c|}{ Gravel } & \multicolumn{7}{|c|}{ Sand } & \multicolumn{3}{|c|}{ Fines } \\
\hline & Coarse & Fine & Tot & \multicolumn{2}{|c|}{ Coarse } & \multicolumn{2}{|c|}{ Medium } & \multicolumn{2}{|c|}{ Fine } & Total & \multicolumn{2}{|r|}{ Clay } & Total \\
\hline 0.0 & 0.0 & 0.0 & 0.0 & 0 & & & & & & 0.4 & 84.4 & 15.2 & 99.6 \\
\hline \multirow[t]{2}{*}{$D_{5}$} & $D_{10}$ & $D_{15}$ & $\mathrm{D}_{20}$ & $D_{30}$ & & & \multicolumn{2}{|c|}{$\mathrm{D}_{50}$} & $D_{60}$ & $D_{80}$ & $D_{85}$ & $\mathrm{D}_{90}$ & $\mathrm{D}_{95}$ \\
\hline & 0.0014 & 0.0048 & 0.0098 & 0.0141 & & & $0.02-2$ & & 0.0345 & 0.0481 & 0.0524 & 0.0574 & 0.0640 \\
\hline \begin{tabular}{|l} 
Fineness \\
Modulus
\end{tabular} & $\mathrm{c}_{\mathrm{u}}$ & $\mathrm{C}_{\mathrm{c}}$ & & & & & & & & & & & \\
\hline 0.01 & 25.29 & 4.21 & & & & & & & & & & & \\
\hline
\end{tabular}




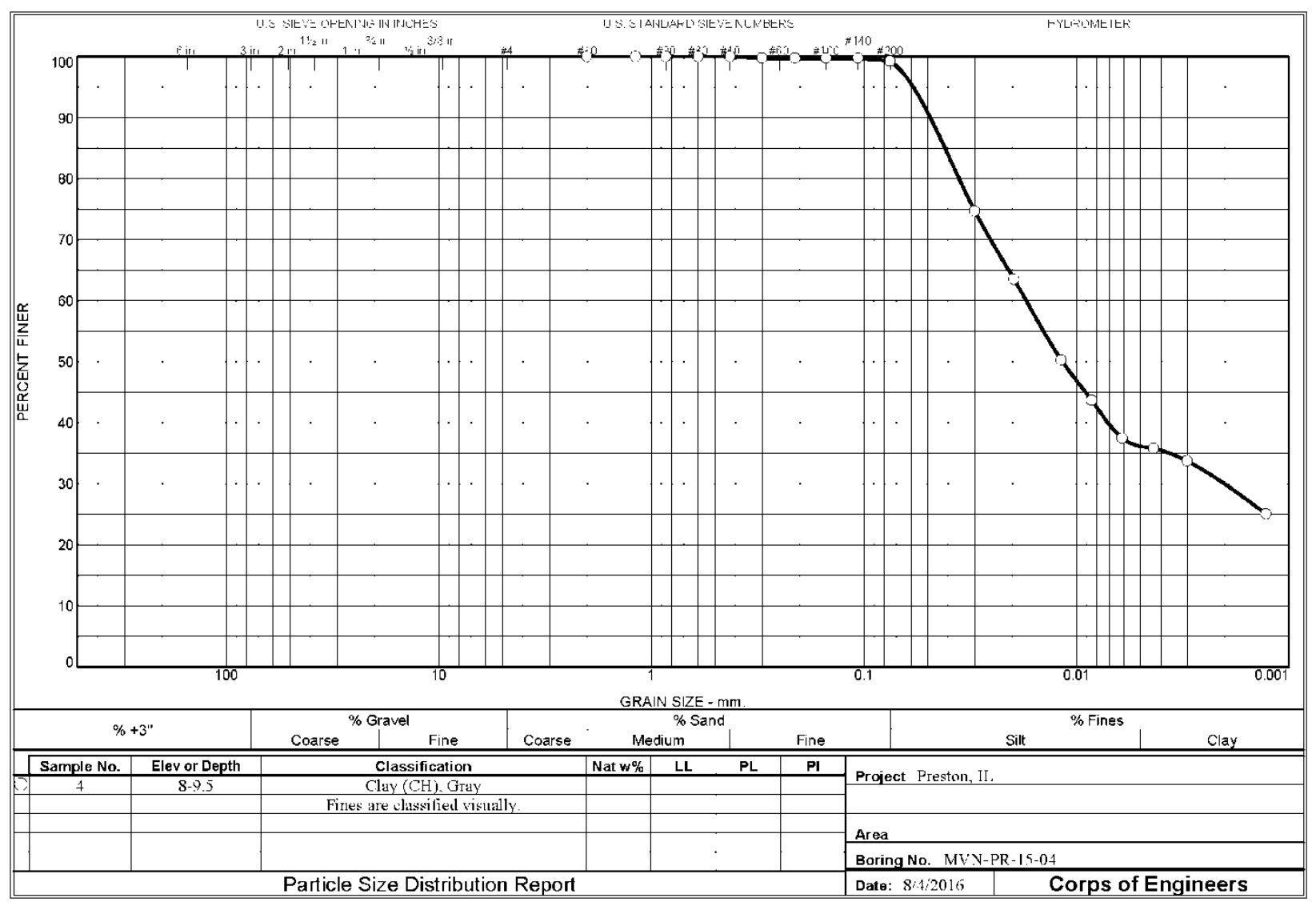

ENG 1 FORM 2087

Tested By: AT/FAN

Checked By: TRJ 
Project: Preston, IL

Location: MVN-PR-15-04

Depth: $8-9.5$

Sample Number: 4

Material Description: Clay $(\mathrm{CH})$, Gray

Fines are classified visually.

Tested by: AT/FAN

Checked by: TRJ

\begin{tabular}{|c|c|c|c|c|c|c|c|c|}
\hline & & & & & & & & \\
\hline & & & & Sieve Te & Test Data & & & \\
\hline $\begin{array}{c}\text { Dry } \\
\text { Sample } \\
\text { and Tare } \\
\text { (grams) }\end{array}$ & $\begin{array}{c}\text { Tare } \\
\text { (grams) }\end{array}$ & $\begin{array}{c}\text { Cumulative } \\
\text { Pan } \\
\text { Tare Weight } \\
\text { (grams) }\end{array}$ & $\begin{array}{l}\mathrm{Sie} \\
\text { Oper } \\
\mathrm{Si}\end{array}$ & & $\begin{array}{c}\text { Cumulative } \\
\text { Weight } \\
\text { Retained } \\
\text { (grams) }\end{array}$ & $\begin{array}{l}\text { Percent } \\
\text { Finer }\end{array}$ & & \\
\hline 38.40 & 0.00 & 0.00 & & $\$ 10$ & 0.00 & 100.0 & & \\
\hline & & & & $\$ 16$ & 0.00 & 100.0 & & \\
\hline & & & & $\$ 20$ & 0.00 & 100.0 & & \\
\hline & & & & $\$ 30$ & 0.00 & 100.0 & & \\
\hline & & & & $\$ 40$ & 0.00 & 100.0 & & \\
\hline & & & & 450 & 0.10 & 99.7 & & \\
\hline & & & & $\$ 70$ & 0.10 & 99.7 & & \\
\hline & & & & 100 & 0.10 & 99.7 & & \\
\hline & & & & 140 & 0.10 & 99.7 & & \\
\hline & & & & 200 & 0.30 & 99.2 & & \\
\hline & & & & drometer & er Test Dat & & & \\
\hline $\begin{array}{l}\text { Hydrometer te } \\
\text { Percent passi } \\
\text { Weight of hyd } \\
\text { Automatic tem } \\
\text { Composite } \\
\text { Meniscus corr } \\
\text { Specific gravit } \\
\text { Hydrometer ty } \\
\text { Hydrometer }\end{array}$ & $\begin{array}{l}t \text { uses mate } \\
\mathrm{g} \# 10 \text { based } \\
\text { ometer samp } \\
\text { verature cor } \\
\text { orrection (fl } \\
\text { ction only = } \\
\text { of solids = } \\
e=151 \mathrm{H} \\
\text { effective dep }\end{array}$ & $\begin{array}{l}\text { ial passing } \# 1 \\
\text { upon complete } \\
\text { le }=38.4 \\
\text { ection } \\
\text { id density and } \\
-0.5 \\
.70 \text { est } \\
\text { th equation: } L\end{array}$ & $\begin{array}{l}0 \\
\text { e sample }=10 \\
=16.294964\end{array}$ & $\begin{array}{l}0.0 \\
\text { ight) at } 2 \\
-0.2645 \times\end{array}$ & $\begin{array}{l}20 \mathrm{deg} . \mathrm{C}= \\
\times \mathrm{Rm}\end{array}$ & & & \\
\hline $\begin{array}{l}\text { Elapsed } \\
\text { Time (min.) }\end{array}$ & $\begin{array}{c}\text { Temp. } \\
\text { (deg. C.) }\end{array}$ & $\begin{array}{c}\text { Actual } \\
\text { Reading }\end{array}$ & $\begin{array}{l}\text { Corrected } \\
\text { Reading }\end{array}$ & K & $\mathrm{Rm}$ & $\begin{array}{l}\text { Eff. } \\
\text { Depth }\end{array}$ & $\begin{array}{l}\text { Diameter } \\
(\mathrm{mm} .)\end{array}$ & $\begin{array}{l}\text { Percent } \\
\text { Finer }\end{array}$ \\
\hline 2.00 & 22.0 & 1.0225 & 1.0181 & 0.0131 & 22.0 & 10.5 & 0.0300 & 74.7 \\
\hline 5.00 & 22.0 & 1.0198 & 1.0154 & 0.0131 & 19.3 & 11.2 & 0.0196 & 63.5 \\
\hline 15.00 & 22.0 & 1.0166 & 1.0122 & 0.0131 & 16.1 & 12.0 & 0.0117 & 50.3 \\
\hline 30.00 & 22.0 & 1.0150 & 1.0106 & 0.0131 & 14.5 & 12.5 & 0.0085 & 43.6 \\
\hline 60.00 & 22.0 & 1.0135 & 1.0091 & 0.0131 & 13.0 & 12.9 & 0.0061 & 37.4 \\
\hline 120.00 & 22.0 & 1.0131 & 1.0087 & 0.0131 & 12.6 & 13.0 & 0.0043 & 35.8 \\
\hline 250.00 & 22.0 & 1.0126 & 1.0082 & 0.0131 & 12.1 & 13.1 & 0.0030 & 33.7 \\
\hline 1440.00 & 22.0 & 1.0105 & 1.0061 & 0.0131 & 10.0 & 13.6 & 0.0013 & 25.0 \\
\hline
\end{tabular}




\begin{tabular}{|c|c|c|c|c|c|c|c|c|c|c|c|c|c|}
\hline \multicolumn{14}{|c|}{ Fractional Components } \\
\hline \multirow{2}{*}{ Cobbles } & \multicolumn{3}{|c|}{ Gravel } & \multicolumn{7}{|c|}{ Sand } & \multicolumn{3}{|c|}{ Fines } \\
\hline & Coarse & Fine & Total & \multicolumn{2}{|c|}{ Coarse } & \multicolumn{2}{|c|}{ Medium } & \multicolumn{2}{|c|}{ Fine } & Total & \multicolumn{2}{|r|}{ Clay } & Total \\
\hline 0.0 & 0.0 & 0.0 & 0.0 & 0.0 & & 0 & & & 8 & 0.8 & 63.0 & 36.2 & 99.2 \\
\hline$D_{5}$ & $\mathrm{D}_{10}$ & $D_{15}$ & $\mathrm{D}_{20}$ & $\mathrm{D}_{30}$ & D & & $D_{s}$ & & $\mathrm{D}_{60}$ & $\mathrm{D}_{80}$ & $D_{85}$ & $\mathrm{D}_{90}$ & $D_{95}$ \\
\hline & & & & 0.0020 & 0.0 & & 0.01 & & 0.0172 & 0.0356 & 0.0415 & 0.0486 & 0.0585 \\
\hline
\end{tabular}

Fineness

Modulus

0.01 


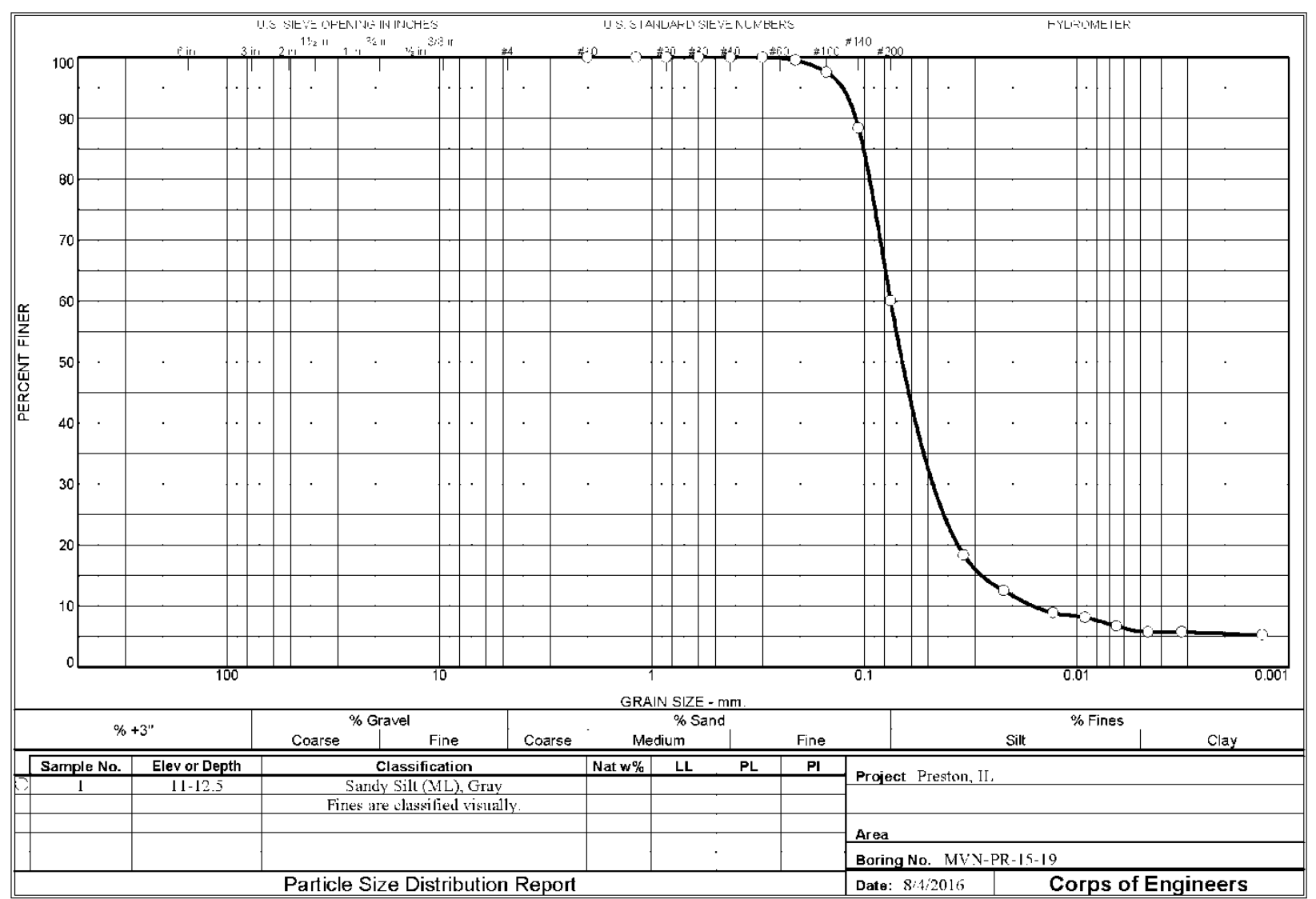

ENG 1 FORM 2087

Tested By: AT/FAN

Checked By: TRJ 
Project: Preston, IL

Location: MVN-PR-15-19

Depth: $11-12.5$

Sample Number: 1

Material Description: Sandy Silt (ML), Gray

Tested by: AT/FAN

Fines are classified visually.

\begin{tabular}{|c|c|c|c|c|c|c|c|c|}
\hline & & & & & & & & \\
\hline & & & & Sieve Tes & est Data & & & \\
\hline $\begin{array}{c}\text { Dry } \\
\text { Sample } \\
\text { and Tare } \\
\text { (grams) }\end{array}$ & $\begin{array}{c}\text { Tare } \\
\text { (grams) }\end{array}$ & $\begin{array}{c}\text { Cumulative } \\
\text { Pan } \\
\text { Tare Weight } \\
\text { (grams) }\end{array}$ & $\begin{array}{l}\mathrm{Sie} \\
\text { Oper } \\
\mathrm{Si}^{2}\end{array}$ & & $\begin{array}{l}\text { umulative } \\
\text { Weight } \\
\text { Retained } \\
\text { (grams) }\end{array}$ & $\begin{array}{l}\text { Percent } \\
\text { Finer }\end{array}$ & & \\
\hline 65.60 & 0.00 & 0.00 & & 110 & 0.00 & 100.0 & & \\
\hline & & & & 416 & 0.00 & 100.0 & & \\
\hline & & & & $¥ 20$ & 0.00 & 100.0 & & \\
\hline & & & & $\$ 30$ & 0.00 & 100.0 & & \\
\hline & & & & $\$ 40$ & 0.00 & 100.0 & & \\
\hline & & & & 450 & 0.00 & 100.0 & & \\
\hline & & & & $\$ 70$ & 0.30 & 99.5 & & \\
\hline & & & & 100 & 1.60 & 97.6 & & \\
\hline & & & & 140 & 7.60 & 88.4 & & \\
\hline & & & & 200 & 26.20 & 60.1 & & \\
\hline & & & & Irometer & r Test Dat & & & \\
\hline $\begin{array}{l}\text { Hydrometer te } \\
\text { Percent passi } \\
\text { Weight of hydr } \\
\text { Automatic tem } \\
\text { Composite } \\
\text { Meniscus corr } \\
\text { Specific gravit } \\
\text { Hydrometer ty } \\
\text { Hydrometer }\end{array}$ & $\begin{array}{l}\text { uses mater } \\
\text { \#10 based } \\
\text { meter samp } \\
\text { erature corr } \\
\text { rrection (flu } \\
\text { ction only = } \\
\text { of solids = } \\
e=151 \mathrm{H} \\
\text { ffective dep }\end{array}$ & $\begin{array}{l}\text { al passing } \# 1 \\
\text { upon complete } \\
\mathrm{e}=65.6 \\
\text { ection } \\
\text { id density and } \\
0.5 \\
.69 \text { est } \\
\text { h equation: L }\end{array}$ & $\begin{array}{l}0 \\
\text { e sample }=10 \\
\text { meniscus he } \\
=16.294964\end{array}$ & $\begin{array}{l}0.0 \\
\text { ight) at } 20 \\
-0.2645 \times\end{array}$ & $\begin{array}{l}0 \text { deg. } C= \\
\times \mathrm{Rm}\end{array}$ & -4.7 & & \\
\hline $\begin{array}{l}\text { Elapsed } \\
\text { Time (min.) }\end{array}$ & $\begin{array}{c}\text { Temp. } \\
\text { (deg. C.) }\end{array}$ & $\begin{array}{c}\text { Actual } \\
\text { Reading }\end{array}$ & $\begin{array}{l}\text { Corrected } \\
\text { Reading }\end{array}$ & $\mathrm{K}$ & $\mathrm{Rm}$ & $\begin{array}{l}\text { Eff. } \\
\text { Depth }\end{array}$ & $\begin{array}{l}\text { Diameter } \\
\text { (mm.) }\end{array}$ & $\begin{array}{l}\text { Percent } \\
\text { Finer }\end{array}$ \\
\hline 2.00 & 22.0 & 1.0120 & 1.0076 & 0.0132 & 11.5 & 13.3 & 0.0339 & 18.3 \\
\hline 5.00 & 22.0 & 1.0096 & 1.0052 & 0.0132 & 9.1 & 13.9 & 0.0219 & 12.5 \\
\hline 15.00 & 22.0 & 1.0081 & 1.0037 & 0.0132 & 7.6 & 14.3 & 0.0128 & 8.9 \\
\hline 30.00 & 22.0 & 1.0078 & 1.0034 & 0.0132 & 7.3 & 14.4 & 0.0091 & 8.1 \\
\hline 60.00 & 22.0 & 1.0072 & 1.0028 & 0.0132 & 6.7 & 14.5 & 0.0065 & 6.7 \\
\hline 120.00 & 22.0 & 1.0068 & 1.0024 & 0.0132 & 6.3 & 14.6 & 0.0046 & 5.7 \\
\hline 250.00 & 22.0 & 1.0068 & 1.0024 & 0.0132 & 6.3 & 14.6 & 0.0032 & 5.7 \\
\hline 1440.00 & 22.0 & 1.0066 & 1.0022 & 0.0132 & 6.1 & 14.7 & 0.0013 & 5.2 \\
\hline
\end{tabular}




\begin{tabular}{|c|c|c|c|c|c|c|c|c|c|c|c|c|}
\hline \multicolumn{13}{|c|}{ Fractional Components } \\
\hline \multirow{2}{*}{ Cobbles } & \multicolumn{3}{|c|}{ Gravel } & \multicolumn{6}{|c|}{ Sand } & \\
\hline & Coarse & Fine & Total & \multicolumn{2}{|c|}{ Coarse } & \multicolumn{2}{|c|}{ Medium } & Fine & Total & \multicolumn{2}{|r|}{$\begin{array}{l}\text { Fines } \\
\text { Clay }\end{array}$} & Total \\
\hline 0.0 & 0.0 & 0.0 & 0.0 & 0. & & 0 & & 39.9 & 39.9 & 54.3 & 5.8 & 60.1 \\
\hline \multirow[t]{2}{*}{$D_{5}$} & $\mathrm{D}_{10}$ & $D_{15}$ & $\mathrm{D}_{20}$ & $D_{30}$ & \multicolumn{2}{|c|}{$\mathrm{D}_{40}$} & $D_{50}$ & $D_{60}$ & $D_{80}$ & $D_{85}$ & $\mathrm{D}_{90}$ & $D_{95}$ \\
\hline & 0.0160 & 0.0280 & 0.0362 & 0.0475 & 0.0 & & 0.06 & 0.07 & 0.0941 & 0.1005 & 0.1092 & 0.1256 \\
\hline \begin{tabular}{|l|}
$\begin{array}{l}\text { Fineness } \\
\text { Modulus }\end{array}$ \\
\end{tabular} & $\mathrm{c}_{\mathrm{u}}$ & $\mathrm{c}_{\mathrm{c}}$ & & & & & & & & & & \\
\hline 0.02 & 4.68 & 1.88 & & & & & & & & & & \\
\hline
\end{tabular}




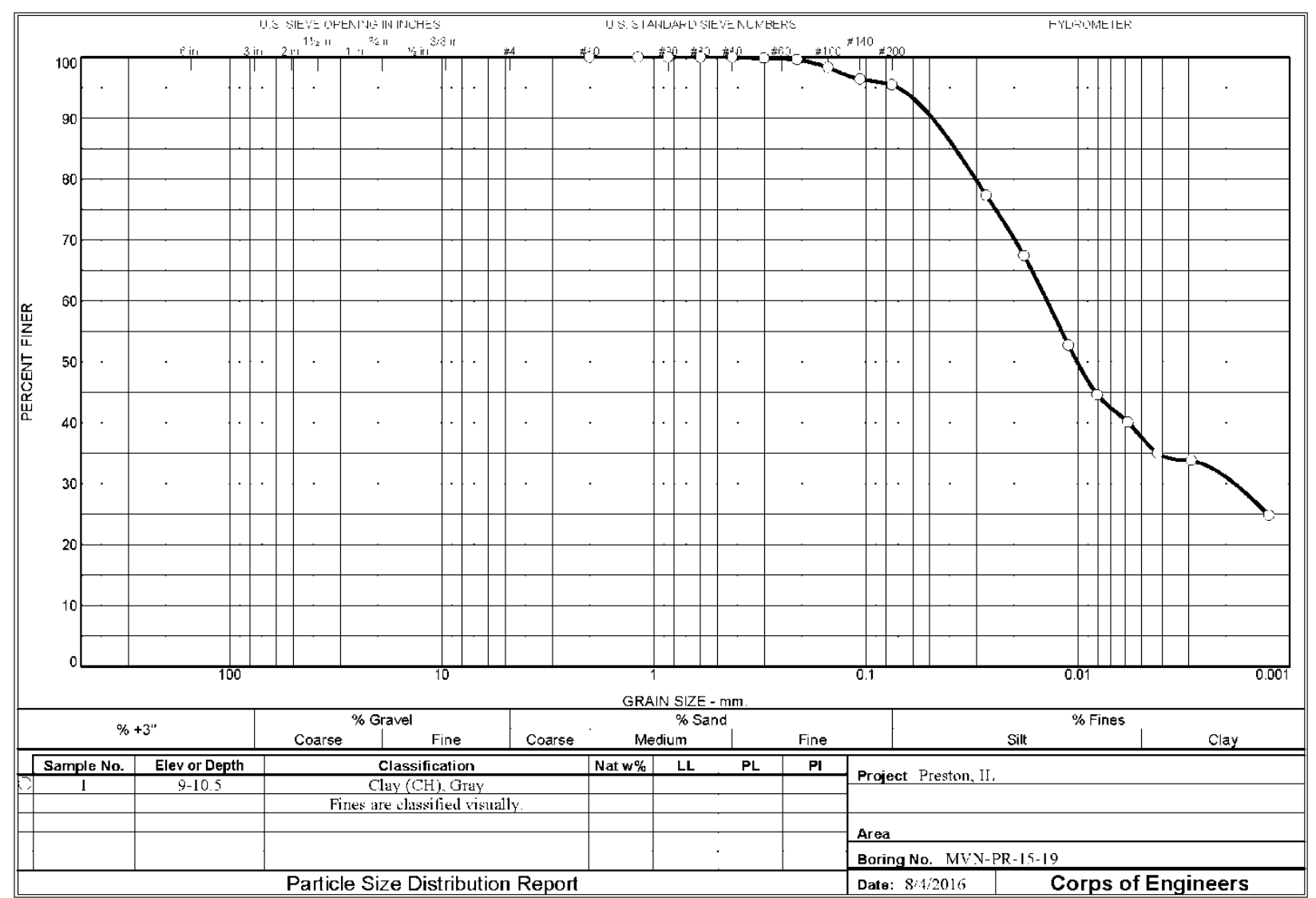

ENG 1 FORM 2087

Tested By: AT/FAN

Checked By: TRJ 
Project: Preston, IL

Location: MVN-PR-15-19

Depth: 9-10.5

Sample Number: 1

Material Description: Clay $(\mathrm{CH})$, Gray

Tested by: AT/FAN

Fines are classified visually.

\begin{tabular}{|c|c|c|c|c|c|c|c|c|}
\hline Tested by: A & & & & & Checked I & y: TRJ & & \\
\hline & & & & Sieve Te & est Data & & & \\
\hline $\begin{array}{c}\text { Dry } \\
\text { Sample } \\
\text { and Tare } \\
\text { (grams) }\end{array}$ & $\begin{array}{c}\text { Tare } \\
\text { (grams) }\end{array}$ & $\begin{array}{c}\text { Cumulative } \\
\text { Pan } \\
\text { Tare Weight } \\
\text { (grams) }\end{array}$ & $\begin{array}{l}\mathrm{Sie} \\
\text { Oper } \\
\mathrm{Si}^{2}\end{array}$ & & $\begin{array}{l}\text { umulative } \\
\text { Weight } \\
\text { Retained } \\
\text { (grams) }\end{array}$ & $\begin{array}{l}\text { Percent } \\
\text { Finer }\end{array}$ & & \\
\hline 52.90 & 0.00 & 0.00 & & 10 & 0.00 & 100.0 & & \\
\hline & & & & 16 & 0.00 & 100.0 & & \\
\hline & & & & 20 & 0.00 & 100.0 & & \\
\hline & & & & 30 & 0.00 & 100.0 & & \\
\hline & & & & 40 & 0.00 & 100.0 & & \\
\hline & & & & 50 & 0.10 & 99.8 & & \\
\hline & & & & 70 & 0.20 & 99.6 & & \\
\hline & & & & 00 & 0.90 & 98.3 & & \\
\hline & & & & 40 & 1.90 & 96.4 & & \\
\hline & & & & 00 & 2.40 & 95.5 & & \\
\hline & & & & rometer & r Test Dat & & & \\
\hline $\begin{array}{l}\text { Hydrometer te } \\
\text { Percent passi } \\
\text { Weight of hyd } \\
\text { Automatic tem } \\
\text { Composite } \\
\text { Meniscus corr } \\
\text { Specific gravi } \\
\text { Hydrometer ty } \\
\text { Hydrometer }\end{array}$ & $\begin{array}{l}\text { uses mate } \\
\# 10 \text { based } \\
\text { meter samp } \\
\text { erature cor } \\
\text { rrection (fly } \\
\text { ction only = } \\
\text { of solids = } \\
e=151 \mathrm{H} \\
\text { ffective dep }\end{array}$ & $\begin{array}{l}\text { al passing } \# 1 \\
\text { upon complet } \\
e=52.9 \\
\text { ection } \\
\text { id density and } \\
0.5 \\
.70 \text { est } \\
h \text { equation: L }\end{array}$ & $\begin{array}{l}\text { meniscus } \mathrm{h} \\
=16.294964\end{array}$ & $\begin{array}{l}.0 \\
0.2645 \times\end{array}$ & $\begin{array}{l}0 \mathrm{deg} . \mathrm{C}= \\
\times \mathrm{Rm}\end{array}$ & & & \\
\hline $\begin{array}{c}\text { Elapsed } \\
\text { Time (min.) }\end{array}$ & $\begin{array}{c}\text { Temp. } \\
\text { (deg. C.) }\end{array}$ & $\begin{array}{c}\text { Actual } \\
\text { Reading }\end{array}$ & $\begin{array}{l}\text { Corrected } \\
\text { Reading }\end{array}$ & K & $\mathrm{Rm}$ & $\begin{array}{c}\text { Eff. } \\
\text { Depth }\end{array}$ & $\begin{array}{l}\text { Diameter } \\
(\mathrm{mm} .)\end{array}$ & $\begin{array}{l}\text { Percent } \\
\text { Finer }\end{array}$ \\
\hline 2.00 & 22.0 & 1.0302 & 1.0258 & 0.0131 & 29.7 & 8.4 & 0.0269 & 77.3 \\
\hline 5.00 & 22.0 & 1.0269 & 1.0225 & 0.0131 & 26.4 & 9.3 & 0.0179 & 67.4 \\
\hline 15.00 & 22.0 & 1.0220 & 1.0176 & 0.0131 & 21.5 & 10.6 & 0.0110 & 52.7 \\
\hline 30.00 & 22.0 & 1.0193 & 1.0149 & 0.0131 & 18.8 & 11.3 & 0.0081 & 44.6 \\
\hline 60.00 & 22.0 & 1.0178 & 1.0134 & 0.0131 & 17.3 & 11.7 & 0.0058 & 40.1 \\
\hline 120.00 & 22.0 & 1.0161 & 1.0117 & 0.0131 & 15.6 & 12.2 & 0.0042 & 35.0 \\
\hline 250.00 & 22.0 & 1.0157 & 1.0113 & 0.0131 & 15.2 & 12.3 & 0.0029 & 33.8 \\
\hline 1440.00 & 22.0 & 1.0127 & 1.0083 & 0.0131 & 12.2 & 13.1 & 0.0012 & 24.8 \\
\hline
\end{tabular}




\begin{tabular}{|c|c|c|c|c|c|c|c|c|c|c|}
\hline \multicolumn{11}{|c|}{ Fractional Components } \\
\hline \multirow{2}{*}{ Cobbles } & \multicolumn{3}{|c|}{ Gravel } & \multicolumn{4}{|c|}{ Sand } & \multicolumn{3}{|c|}{ Fines } \\
\hline & Coarse & Fine & Total & Coarse & Medium & Fine & Total & Silt & Clay & Total \\
\hline 0.0 & 0.0 & 0.0 & 0.0 & 0.0 & 0.0 & 4.5 & 4.5 & 57.9 & 37.6 & 95.5 \\
\hline
\end{tabular}

\begin{tabular}{|c|c|c|c|c|c|c|c|c|c|c|c|}
\hline $\mathrm{D}_{\mathbf{5}}$ & $\mathrm{D}_{\mathbf{1 0}}$ & $\mathrm{D}_{\mathbf{1 5}}$ & $\mathrm{D}_{\mathbf{2 0}}$ & $\mathrm{D}_{\mathbf{3 0}}$ & $\mathrm{D}_{\mathbf{4 0}}$ & $\mathrm{D}_{\mathbf{5 0}}$ & $\mathrm{D}_{\mathbf{6 0}}$ & $\mathrm{D}_{\mathbf{8 0}}$ & $\mathrm{D}_{\mathbf{8 5}}$ & $\mathrm{D}_{\mathbf{9 0}}$ & $\mathrm{D}_{\mathbf{9 5}}$ \\
\hline & & & & 0.0018 & 0.0058 & 0.0101 & 0.0139 & 0.0303 & 0.0378 & 0.0484 & 0.0701 \\
\hline
\end{tabular}

Fineness

Modulus

0.02 


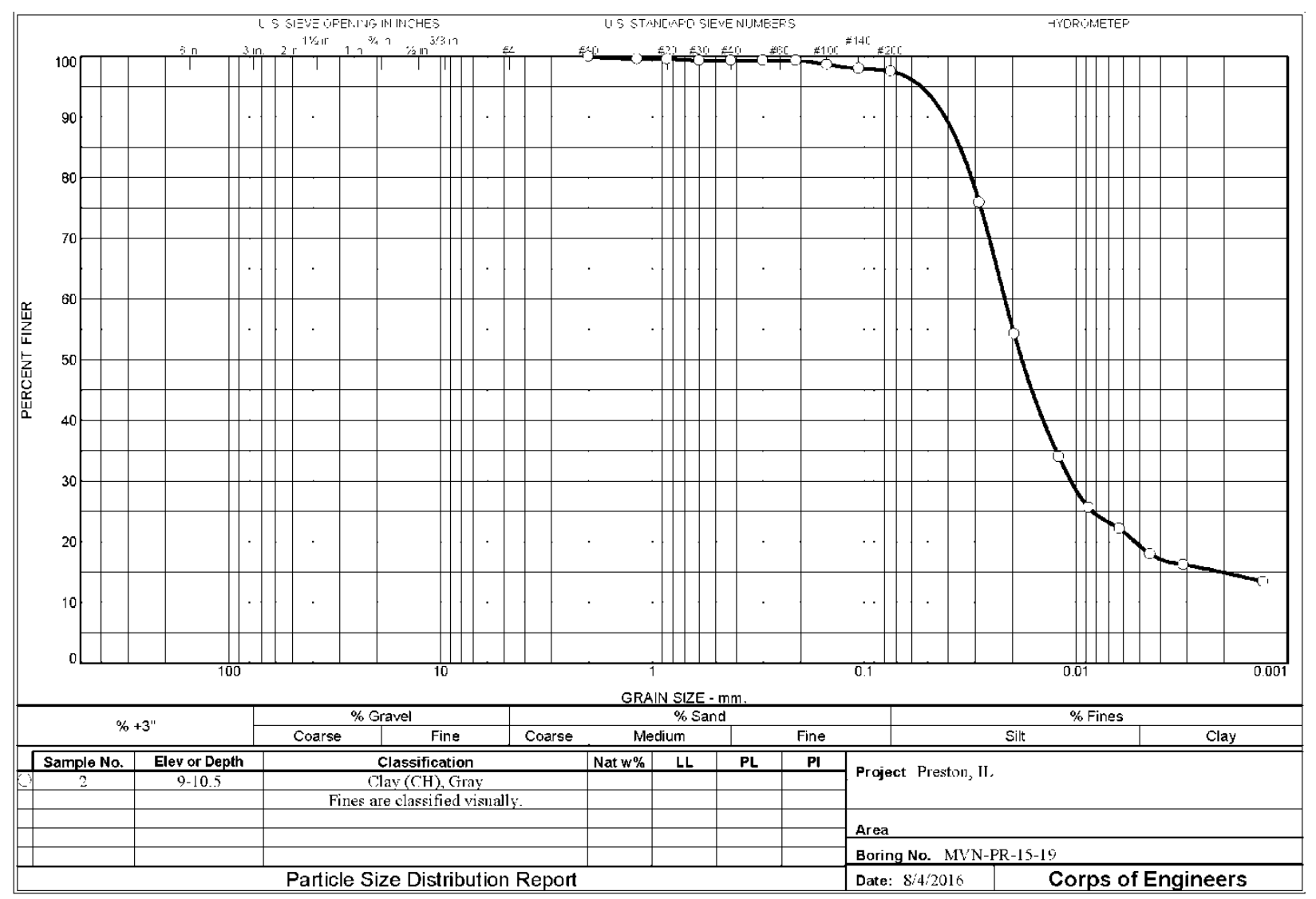

ENG 1 MORM 2087

Tested By: AT/FAN

Checked By: TRJ 
GRAIN SIZE DISTRIBUTION TEST DATA

$8 / 4 / 2016$

Project: Preston, IL

Location: MVN-PR-15-19

Depth: 9-10.5

Sample Number: 2

Material Description: Clay (CH), Gray

Tested by: AT/FAN

Fines are classified visually.

\begin{tabular}{|c|c|c|c|c|c|c|c|c|}
\hline Tested by: A & & & & & Checked I & y: TRJ & & \\
\hline & & & & Sieve Te & est Data & & & \\
\hline $\begin{array}{c}\text { Dry } \\
\text { Sample } \\
\text { and Tare } \\
\text { (grams) }\end{array}$ & $\begin{array}{c}\text { Tare } \\
\text { (grams) }\end{array}$ & $\begin{array}{c}\text { Cumulative } \\
\text { Pan } \\
\text { Tare Weight } \\
\text { (grams) }\end{array}$ & $\begin{array}{l}\mathrm{Sie} \\
\text { Oper } \\
\mathrm{Si}^{2}\end{array}$ & & $\begin{array}{l}\text { umulative } \\
\text { Weight } \\
\text { Retained } \\
\text { (grams) }\end{array}$ & $\begin{array}{l}\text { Percent } \\
\text { Finer }\end{array}$ & & \\
\hline 45.50 & 0.00 & 0.00 & & 10 & 0.00 & 100.0 & & \\
\hline & & & & 16 & 0.20 & 99.6 & & \\
\hline & & & & 20 & 0.20 & 99.6 & & \\
\hline & & & & 30 & 0.30 & 99.3 & & \\
\hline & & & & 40 & 0.30 & 99.3 & & \\
\hline & & & & 50 & 0.30 & 99.3 & & \\
\hline & & & & 70 & 0.30 & 99.3 & & \\
\hline & & & & 00 & 0.60 & 98.7 & & \\
\hline & & & & 40 & 0.90 & 98.0 & & \\
\hline & & & & 00 & 1.10 & 97.6 & & \\
\hline & & & & rometer & r Test Dat & & & \\
\hline $\begin{array}{l}\text { Hydrometer te } \\
\text { Percent passi } \\
\text { Weight of hyd } \\
\text { Automatic tem } \\
\text { Composite } \\
\text { Meniscus corr } \\
\text { Specific gravi } \\
\text { Hydrometer ty } \\
\text { Hydrometer }\end{array}$ & $\begin{array}{l}\text { uses mate } \\
\# 10 \text { based } \\
\text { meter samp } \\
\text { erature cor } \\
\text { orrection (fly } \\
\text { ction only = } \\
\text { of solids = } \\
e=151 \mathrm{H} \\
\text { ffective dep }\end{array}$ & $\begin{array}{l}\text { al passing } \# 1 \\
\text { upon complet } \\
\mathrm{e}=45.5 \\
\text { ection } \\
\text { id density and } \\
0.5 \\
.70 \text { est } \\
\mathrm{h} \text { equation: } \mathrm{L}\end{array}$ & $\begin{array}{l}\text { sample }=1 \\
\text { meniscus } h \\
=16.294964\end{array}$ & $\begin{array}{l}0.0 \\
0.2645 \times\end{array}$ & $\begin{array}{l}0 \mathrm{deg} . \mathrm{C}= \\
\times \mathrm{Rm}\end{array}$ & & & \\
\hline $\begin{array}{c}\text { Elapsed } \\
\text { Time (min.) }\end{array}$ & $\begin{array}{c}\text { Temp. } \\
\text { (deg. C.) }\end{array}$ & $\begin{array}{c}\text { Actual } \\
\text { Reading }\end{array}$ & $\begin{array}{l}\text { Corrected } \\
\text { Reading }\end{array}$ & K & $\mathrm{Rm}$ & $\begin{array}{c}\text { Eff. } \\
\text { Depth }\end{array}$ & $\begin{array}{c}\text { Diameter } \\
(\mathrm{mm} .)\end{array}$ & $\begin{array}{l}\text { Percent } \\
\text { Finer }\end{array}$ \\
\hline 2.00 & 22.0 & 1.0262 & 1.0218 & 0.0131 & 25.7 & 9.5 & 0.0286 & 75.9 \\
\hline 5.00 & 22.0 & 1.0200 & 1.0156 & 0.0131 & 19.5 & 11.1 & 0.0196 & 54.3 \\
\hline 15.00 & 22.0 & 1.0142 & 1.0098 & 0.0131 & 13.7 & 12.7 & 0.0121 & 34.0 \\
\hline 30.00 & 22.0 & 1.0118 & 1.0074 & 0.0131 & 11.3 & 13.3 & 0.0087 & 25.7 \\
\hline 60.00 & 22.0 & 1.0108 & 1.0064 & 0.0131 & 10.3 & 13.6 & 0.0062 & 22.2 \\
\hline 120.00 & 22.0 & 1.0096 & 1.0052 & 0.0131 & 9.1 & 13.9 & 0.0045 & 18.0 \\
\hline 250.00 & 22.0 & 1.0091 & 1.0047 & 0.0131 & 8.6 & 14.0 & 0.0031 & 16.2 \\
\hline 1440.00 & 22.0 & 1.0083 & 1.0039 & 0.0131 & 7.8 & 14.2 & 0.0013 & 13.4 \\
\hline
\end{tabular}




\begin{tabular}{|c|c|c|c|c|c|c|c|c|c|c|}
\hline \multicolumn{11}{|c|}{ Fractional Components } \\
\hline \multirow{2}{*}{ Cobbles } & \multicolumn{3}{|c|}{ Gravel } & \multicolumn{4}{|c|}{ Sand } & \multicolumn{3}{|c|}{ Fines } \\
\hline & Coarse & Fine & Total & Coarse & Medium & Fine & Total & Silt & Clay & Total \\
\hline 0.0 & 0.0 & 0.0 & 0.0 & 0.0 & 0.7 & 1.7 & 2.4 & 78.3 & 19.3 & 97.6 \\
\hline
\end{tabular}

\begin{tabular}{|c|c|c|c|c|c|c|c|c|c|c|c|}
\hline $\mathbf{D}_{\mathbf{5}}$ & $\mathbf{D}_{\mathbf{1 0}}$ & $\mathbf{D}_{\mathbf{1 5}}$ & $\mathbf{D}_{\mathbf{2 0}}$ & $\mathbf{D}_{\mathbf{3 0}}$ & $\mathbf{D}_{\mathbf{4 0}}$ & $\mathbf{D}_{\mathbf{5 0}}$ & $\mathbf{D}_{\mathbf{6 0}}$ & $\mathbf{D}_{\mathbf{8 0}}$ & $\mathbf{D}_{\mathbf{8 5}}$ & $\mathbf{D}_{\mathbf{9 0}}$ & $\mathbf{D}_{\mathbf{9 5}}$ \\
\hline & & 0.0020 & 0.0053 & 0.0106 & 0.0143 & 0.0180 & 0.0217 & 0.0311 & 0.0352 & 0.0414 & 0.0537 \\
\hline
\end{tabular}

Fineness

Modulus

0.03 


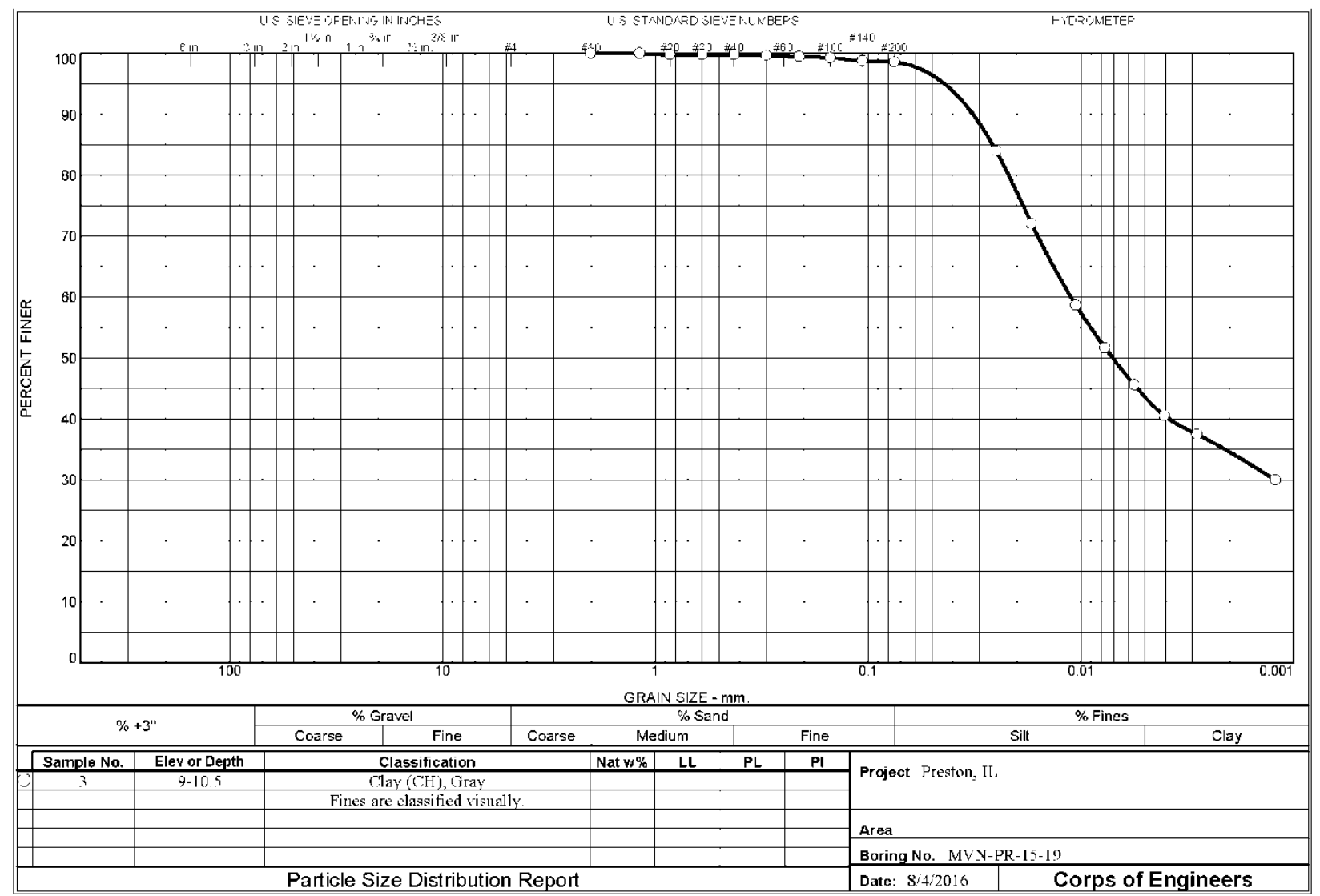

ENG 1 FORM 2087

Tested By: AT/FAN

Checked By: TRJ 
GRAIN SIZE DISTRIBUTION TEST DATA

Project: Preston, $\mathbb{I L}$

Location: MVN-PR-15-19

Depth: 9-10.5

Sample Number: 3

Material Description: Clay $(\mathrm{CH})$, Gray

Fines are classified visually.

Tested by: AT/FAN

Checked by: TRJ

\begin{tabular}{|c|c|c|c|c|c|c|c|c|}
\hline & \multicolumn{8}{|c|}{ Sieve Test Data } \\
\hline $\begin{array}{c}\text { Dry } \\
\text { Sample } \\
\text { and Tare } \\
\text { (grams) }\end{array}$ & $\begin{array}{c}\text { Tare } \\
\text { (grams) }\end{array}$ & $\begin{array}{l}\text { Cumulative } \\
\text { Pan } \\
\text { Tare Weight } \\
\text { (grams) }\end{array}$ & $\begin{array}{l}\mathrm{Si} \\
\text { Ope } \\
\mathrm{Si}\end{array}$ & & $\begin{array}{l}\text { umulative } \\
\text { Weight } \\
\text { Retained } \\
\text { (grams) }\end{array}$ & $\begin{array}{l}\text { Percent } \\
\text { Finer }\end{array}$ & & \\
\hline 57.00 & 0.00 & 0.00 & & $\begin{array}{l}10 \\
16 \\
20 \\
30 \\
40 \\
50 \\
70 \\
00 \\
40 \\
00\end{array}$ & $\begin{array}{l}0.00 \\
0.00 \\
0.10 \\
0.10 \\
0.10 \\
0.20 \\
0.30 \\
0.40 \\
0.70 \\
0.80\end{array}$ & $\begin{array}{r}100.0 \\
100.0 \\
99.8 \\
99.8 \\
99.8 \\
99.6 \\
99.5 \\
99.3 \\
98.8 \\
98.6\end{array}$ & & \\
\hline \multicolumn{9}{|c|}{$\begin{array}{l}\text { Hydrometer test uses material passing } \# 10 \\
\text { Percent passing } \# 10 \text { based upon complete sample }=100.0 \\
\text { Weight of hydrometer sample }=57.0 \\
\text { Automatic temperature correction } \\
\text { Composite correction (fluid density and meniscus height) at } 20 \text { deg. } C=-4.7 \\
\text { Meniscus correction only }=-0.5 \\
\text { Specific gravity of solids }=2.70 \text { est } \\
\text { Hydrometer type }=151 \mathrm{H} \\
\text { Hydrometer effective depth equation: } L=16.294964-0.2645 \times \mathrm{Rm}\end{array}$} \\
\hline $\begin{array}{l}\text { Elapsed } \\
\text { Time (min.) }\end{array}$ & $\begin{array}{l}\text { Temp. } \\
\text { (deg. C.) }\end{array}$ & $\begin{array}{l}\text { Actual } \\
\text { Reading }\end{array}$ & $\begin{array}{l}\text { Corrected } \\
\text { Reading }\end{array}$ & $\mathrm{K}$ & $\mathrm{Rm}$ & $\begin{array}{l}\text { Eff. } \\
\text { Depth }\end{array}$ & $\begin{array}{c}\text { Diameter } \\
(\mathrm{mm} .)\end{array}$ & $\begin{array}{c}\text { Percent } \\
\text { Finer }\end{array}$ \\
\hline 2.00 & 22.0 & 1.0346 & 1.0302 & 0.0131 & 34.1 & 7.3 & 0.0250 & 84.0 \\
\hline 5.00 & 22.0 & 1.0303 & 1.0259 & 0.0131 & 29.8 & 8.4 & 0.0170 & 72.0 \\
\hline 15.00 & 22.0 & 1.0255 & 1.0211 & 0.0131 & 25.0 & 9.7 & 0.0105 & 58.7 \\
\hline 30.00 & 22.0 & 1.0230 & 1.0186 & 0.0131 & 22.5 & 10.3 & 0.0077 & 51.7 \\
\hline 60.00 & 22.0 & 1.0208 & 1.0164 & 0.0131 & 20.3 & 10.9 & 0.0056 & 45.6 \\
\hline 120.00 & 22.0 & 1.0190 & 1.0146 & 0.0131 & 18.5 & 11.4 & 0.0040 & 40.5 \\
\hline 250.00 & 22.0 & 1.0179 & 1.0135 & 0.0131 & 17.4 & 11.7 & 0.0028 & 37.5 \\
\hline 1440.00 & 22.0 & 1.0152 & 1.0108 & 0.0131 & 14.7 & 12.4 & 0.0012 & 30.0 \\
\hline
\end{tabular}




\begin{tabular}{|c|c|c|c|c|c|c|c|c|c|c|c|c|}
\hline \multicolumn{13}{|c|}{ Fractional Components } \\
\hline \multirow{2}{*}{ Cobbles } & \multicolumn{3}{|c|}{ Gravel } & \multicolumn{6}{|c|}{ Sand } & \multicolumn{3}{|c|}{ Fines } \\
\hline & Coarse & Fine & Total & \multicolumn{2}{|c|}{ Coarse } & \multicolumn{2}{|c|}{ Medium } & Fine & Total & \multicolumn{2}{|r|}{ Clay } & Total \\
\hline 0.0 & 0.0 & 0.0 & 0.0 & 0.0 & & 0 & & 1.2 & 1.4 & 55.0 & 43.6 & 98.6 \\
\hline$D_{5}$ & $\mathrm{D}_{10}$ & $\mathrm{D}_{15}$ & $\mathrm{D}_{20}$ & $\mathrm{D}_{30}$ & $\mathrm{D}$ & & $D_{50}$ & & $\mathrm{D}_{80}$ & $D_{85}$ & $\mathrm{D}_{90}$ & $\mathrm{D}_{95}$ \\
\hline & & & & 0.0012 & 0.0 & & 0.007 & 0.0 & 0.0218 & 0.0259 & 0.0321 & 0.0437 \\
\hline
\end{tabular}

Fineness

Modulus

0.01 


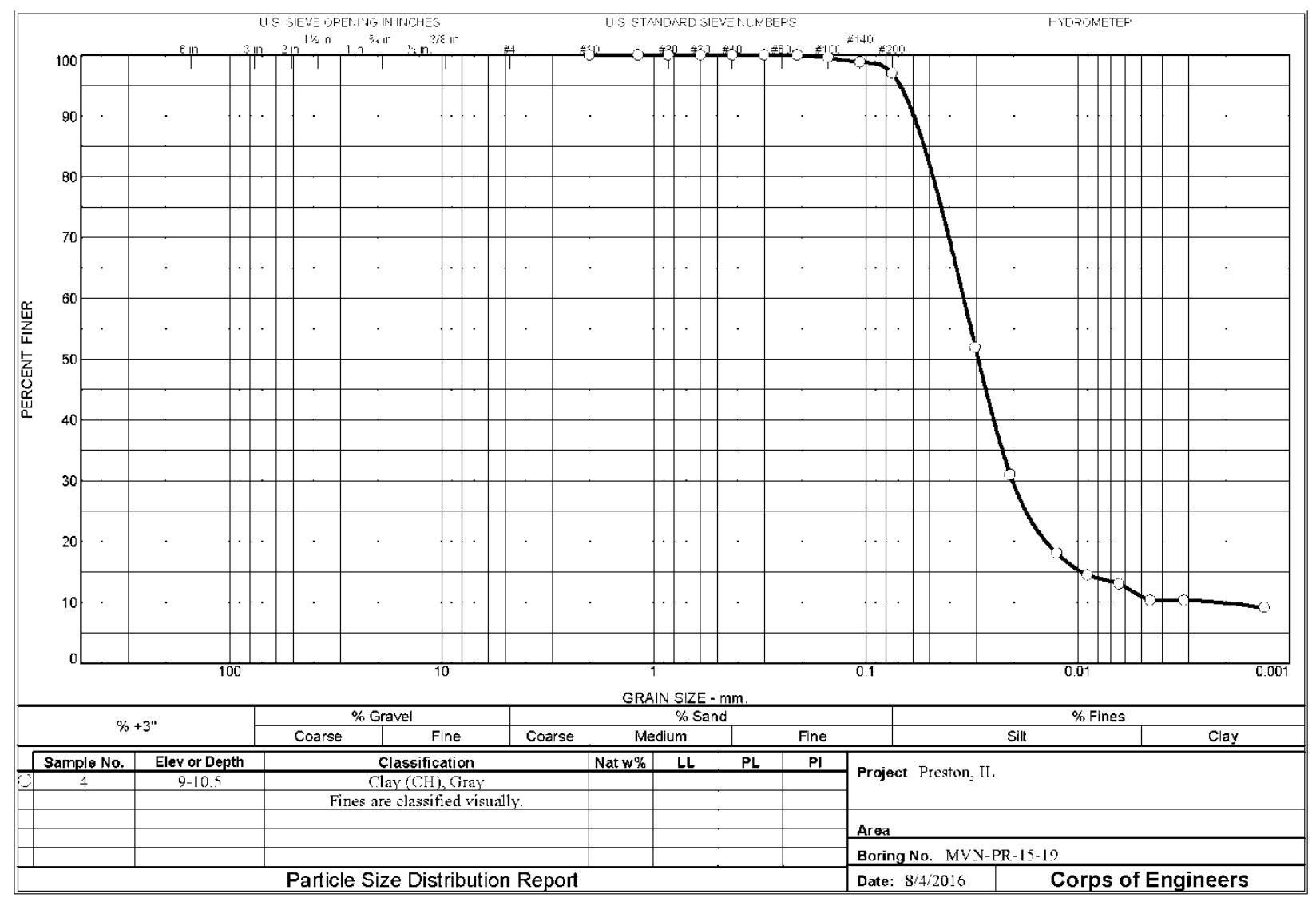

ENG 1 MORM 2087

Tested By: AT/FAN Checked By: TRJ 
GRAIN SIZE DISTRIBUTION TEST DATA

$8 / 4 / 2016$

Project: Preston, IL

Location: MVN-PR-15-19

Depth: 9-10.5

Sample Number: 4

Material Description: Clay $(\mathrm{CH})$, Gray

Fines are classified visually.

Tested by: AT/FAN

Checked by: TRJ

\begin{tabular}{|c|c|c|c|c|c|c|c|c|}
\hline \multicolumn{9}{|c|}{ Sieve Test Data } \\
\hline $\begin{array}{c}\text { Dry } \\
\text { Sample } \\
\text { and Tare } \\
\text { (grams) }\end{array}$ & $\begin{array}{c}\text { Tare } \\
\text { (grams) }\end{array}$ & $\begin{array}{l}\text { Cumulative } \\
\text { Pan } \\
\text { Tare Weight } \\
\text { (grams) }\end{array}$ & \multicolumn{2}{|c|}{$\begin{array}{l}\text { Sieve } \\
\text { Opening } \\
\text { Size }\end{array}$} & $\begin{array}{l}\text { Cumulative } \\
\text { Weight } \\
\text { Retained } \\
\text { (grams) }\end{array}$ & \multicolumn{2}{|c|}{$\begin{array}{l}\text { Percent } \\
\text { Finer }\end{array}$} & \\
\hline \multirow[t]{10}{*}{53.20} & \multirow[t]{10}{*}{0.00} & \multirow[t]{10}{*}{0.00} & \multicolumn{2}{|c|}{$\# 10$} & 0.00 & \multicolumn{2}{|l|}{100.0} & \\
\hline & & & \multicolumn{2}{|c|}{$\# 16$} & 0.00 & \multicolumn{2}{|l|}{100.0} & \\
\hline & & & \multicolumn{2}{|c|}{$\# 20$} & 0.00 & \multicolumn{2}{|l|}{100.0} & \\
\hline & & & \multicolumn{2}{|c|}{$\# 30$} & 0.00 & \multicolumn{2}{|l|}{100.0} & \\
\hline & & & \multicolumn{2}{|c|}{$\# 40$} & 0.00 & \multicolumn{2}{|l|}{100.0} & \\
\hline & & & \multicolumn{2}{|c|}{$\# 50$} & 0.00 & \multicolumn{2}{|l|}{100.0} & \\
\hline & & & \multicolumn{2}{|c|}{$\# 70$} & 0.00 & \multicolumn{2}{|l|}{100.0} & \\
\hline & & & \multicolumn{2}{|c|}{$\# 100$} & 0.20 & \multicolumn{2}{|l|}{99.6} & \\
\hline & & & \multicolumn{2}{|c|}{$\# 140$} & 0.60 & \multicolumn{2}{|l|}{98.9} & \\
\hline & & & \multicolumn{2}{|c|}{$\# 200$} & 1.60 & \multicolumn{2}{|l|}{97.0} & \\
\hline \multicolumn{9}{|c|}{ Hydrometer Test Data } \\
\hline \multicolumn{9}{|c|}{$\begin{array}{l}\text { Hydrometer test uses material passing } \# 10 \\
\text { Percent passing } \# 10 \text { based upon complete sample }=100.0 \\
\text { Weight of hydrometer sample }=53.2 \\
\text { Automatic temperature correction } \\
\text { Composite correction (fluid density and meniscus height) at } 20 \text { deg. } C=-4.7 \\
\text { Meniscus correction only }=-0.5 \\
\text { Specific gravity of solids }=2.69 \text { est } \\
\text { Hydrometer type }=151 \mathrm{H} \\
\text { Hydrometer effective depth equation: } \mathrm{L}=16.294964-0.2645 \times \mathrm{Rm}\end{array}$} \\
\hline $\begin{array}{c}\text { Elapsed } \\
\text { Time (min.) }\end{array}$ & $\begin{array}{l}\text { Temp. } \\
\text { (deg. C.) }\end{array}$ & $\begin{array}{l}\text { Actual } \\
\text { Reading }\end{array}$ & $\begin{array}{l}\text { Corrected } \\
\text { Reading }\end{array}$ & K & $\mathbf{R m}$ & $\begin{array}{l}\text { Eff. } \\
\text { Depth }\end{array}$ & $\begin{array}{c}\text { Diameter } \\
(\mathrm{mm} .)\end{array}$ & $\begin{array}{l}\text { Percent } \\
\text { Finer }\end{array}$ \\
\hline 2.00 & 22.0 & 1.0218 & 1.0174 & 0.0132 & 21.3 & 10.7 & 0.0304 & 51.9 \\
\hline 5.00 & 22.0 & 1.0148 & 1.0104 & 0.0132 & 14.3 & 12.5 & 0.0208 & 31.0 \\
\hline 15.00 & 22.0 & 1.0105 & 1.0061 & 0.0132 & 10.0 & 13.6 & 0.0125 & 18.1 \\
\hline 30.00 & 22.0 & 1.0093 & 1.0049 & 0.0132 & 8.8 & 14.0 & 0.0090 & 14.5 \\
\hline 60.00 & 22.0 & 1.0088 & 1.0044 & 0.0132 & 8.3 & 14.1 & 0.0064 & 13.0 \\
\hline 120.00 & 22.0 & 1.0079 & 1.0035 & 0.0132 & 7.4 & 14.3 & 0.0045 & 10.3 \\
\hline 250.00 & 22.0 & 1.0079 & 1.0035 & 0.0132 & 7.4 & 14.3 & 0.0032 & 10.3 \\
\hline 1440.00 & 22.0 & 1.0075 & 1.0031 & 0.0132 & 7.0 & 14.4 & 0.0013 & 9.1 \\
\hline
\end{tabular}




\begin{tabular}{|c|c|c|c|c|c|c|c|c|c|c|c|c|c|}
\hline \multicolumn{14}{|c|}{ Fractional Components } \\
\hline \multirow{2}{*}{ Cobbles } & \multicolumn{3}{|c|}{ Gravel } & \multicolumn{7}{|c|}{ Sand } & \multicolumn{3}{|c|}{ Fines } \\
\hline & Coarse & Fine & Total & \multicolumn{2}{|c|}{ Coarse } & \multicolumn{2}{|c|}{ Medium } & \multicolumn{2}{|c|}{ Fine } & Total & \multicolumn{2}{|r|}{ Clay } & Total \\
\hline 0.0 & 0.0 & 0.0 & 0.0 & 0.0 & & 0. & & & & 3.0 & 86.0 & 11.0 & 97.0 \\
\hline \multirow[t]{2}{*}{$\mathrm{D}_{5}$} & $D_{10}$ & $\mathrm{D}_{15}$ & $\mathrm{D}_{20}$ & $\mathrm{D}_{30}$ & D & & $\mathrm{D}_{5}$ & & $\mathrm{D}_{60}$ & $\mathrm{D}_{\mathbf{8 0}}$ & $D_{85}$ & $\mathrm{D}_{90}$ & $\mathrm{D}_{95}$ \\
\hline & 0.0021 & 0.0096 & 0.0141 & 0.0203 & 0.0 & & 0.02 & & 0.0345 & 0.0481 & 0.0530 & 0.0593 & 0.0686 \\
\hline
\end{tabular}

\begin{tabular}{|c|c|c|}
\hline $\begin{array}{c}\text { Fineness } \\
\text { Modulus }\end{array}$ & $\mathrm{c}_{\mathbf{u}}$ & $\mathrm{c}_{\mathbf{c}}$ \\
\hline 0.00 & 16.19 & 5.62 \\
\hline
\end{tabular}




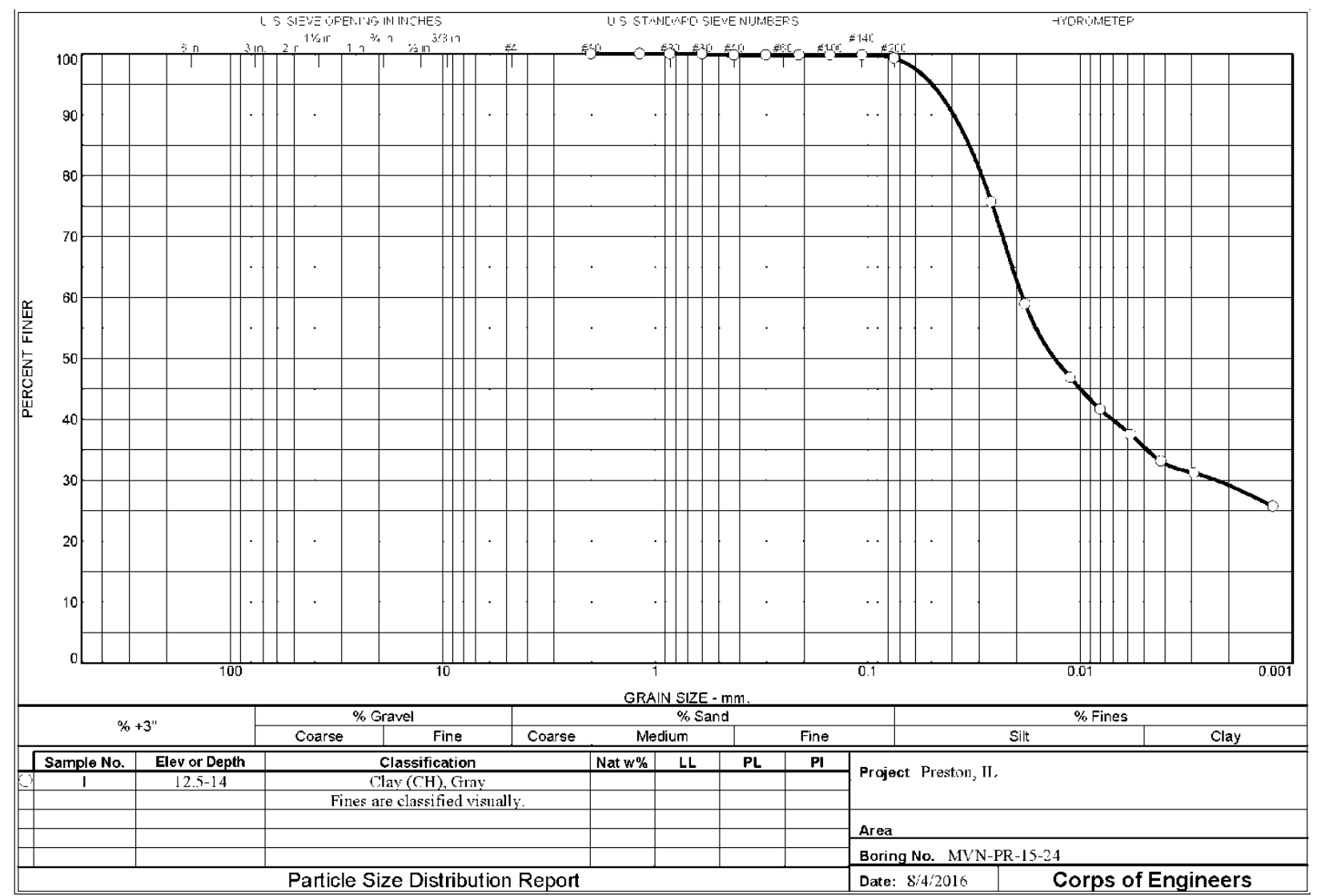

ENG 1 MORM 2087

Tested By: AT/FAN

Checked By: TRJ 
GRAIN SIZE DISTRIBUTION TEST DATA

8/4/2016

Project: Preston, IL

Location: MVN-PR-15-24

Depth: $12.5-14$

Sample Number: 1

Material Description: Clay (CH), Gray

Fines are classified visually.

Tested by: AT/FAN

Checked by: TRJ

\begin{tabular}{|c|c|c|c|c|c|c|c|c|}
\hline & & & & Sieve Te & Test Data & & & \\
\hline $\begin{array}{c}\text { Dry } \\
\text { Sample } \\
\text { and Tare } \\
\text { (grams) }\end{array}$ & $\begin{array}{c}\text { Tare } \\
\text { (grams) }\end{array}$ & $\begin{array}{c}\text { Cumulative } \\
\text { Pan } \\
\text { Tare Weight } \\
\text { (grams) }\end{array}$ & $\begin{array}{r}\mathrm{Si} \\
\text { Ope } \\
\mathrm{Si}\end{array}$ & & $\begin{array}{c}\text { Cumulative } \\
\text { Weight } \\
\text { Retained } \\
\text { (grams) }\end{array}$ & $\begin{array}{l}\text { Percent } \\
\text { Finer }\end{array}$ & & \\
\hline 57.80 & 0.00 & 0.00 & & 10 & 0.00 & 100.0 & & \\
\hline & & & & 16 & 0.00 & 100.0 & & \\
\hline & & & & 20 & 0.00 & 100.0 & & \\
\hline & & & & 30 & 0.00 & 100.0 & & \\
\hline & & & & 40 & 0.10 & 99.8 & & \\
\hline & & & & 50 & 0.10 & 99.8 & & \\
\hline & & & & 770 & 0.10 & 99.8 & & \\
\hline & & & & 00 & 0.10 & 99.8 & & \\
\hline & & & & 40 & 0.10 & 99.8 & & \\
\hline & & & & 00 & 0.40 & 99.3 & & \\
\hline & & & & rometer & er Test Dat & & & \\
\hline $\begin{array}{l}\text { Hydrometer tes } \\
\text { Percent passin } \\
\text { Weight of hydr } \\
\text { Automatic tem } \\
\text { Composite } \\
\text { Meniscus corre } \\
\text { Specific gravity } \\
\text { Hydrometer ty } \\
\text { Hydrometer }\end{array}$ & $\begin{array}{l}t \text { uses mate } \\
\# 10 \text { based } \\
\text { meter sam } \\
\text { erature cor } \\
\text { orrection (fl } \\
\text { ction only = } \\
\text { of solids = } \\
e=151 \mathrm{H} \\
\text { ffective de }\end{array}$ & $\begin{array}{l}\text { ial passing } \# 1 \\
\text { upon complet } \\
\text { le }=57.8 \\
\text { ection } \\
\text { id density and } \\
-0.5 \\
.70 \text { est } \\
\text { h equation: L }\end{array}$ & $\begin{array}{l}\text { meniscus } \mathrm{h} \\
=16.294964\end{array}$ & $\begin{array}{l}0.0 \\
0.2645 \times\end{array}$ & $\begin{array}{l}20 \text { deg. } C= \\
\times \mathrm{Rm}\end{array}$ & & & \\
\hline $\begin{array}{l}\text { Elapsed } \\
\text { Time (min.) }\end{array}$ & $\begin{array}{l}\text { Temp. } \\
\text { (deg. C.) }\end{array}$ & $\begin{array}{c}\text { Actual } \\
\text { Reading }\end{array}$ & $\begin{array}{l}\text { Corrected } \\
\text { Reading }\end{array}$ & $\mathrm{K}$ & Rm & $\begin{array}{l}\text { Eff. } \\
\text { Depth }\end{array}$ & $\begin{array}{l}\text { Diameter } \\
(\mathrm{mm} .)\end{array}$ & $\begin{array}{l}\text { Percent } \\
\text { Finer }\end{array}$ \\
\hline 2.00 & 22.0 & 1.0320 & 1.0276 & 0.0131 & 31.5 & 8.0 & 0.0262 & 75.7 \\
\hline 5.00 & 22.0 & 1.0259 & 1.0215 & 0.0131 & 25.4 & 9.6 & 0.0182 & 58.9 \\
\hline 15.00 & 22.0 & 1.0215 & 1.0171 & 0.0131 & 21.0 & 10.7 & 0.0111 & 46.9 \\
\hline 30.00 & 22.0 & 1.0196 & 1.0152 & 0.0131 & 19.1 & 11.2 & 0.0080 & 41.6 \\
\hline 60.00 & 22.0 & 1.0181 & 1.0137 & 0.0131 & 17.6 & 11.6 & 0.0058 & 37.5 \\
\hline 120.00 & 22.0 & 1.0165 & 1.0121 & 0.0131 & 16.0 & 12.1 & 0.0042 & 33.1 \\
\hline 250.00 & 22.0 & 1.0158 & 1.0114 & 0.0131 & 15.3 & 12.2 & 0.0029 & 31.2 \\
\hline 1440.00 & 22.0 & 1.0138 & 1.0094 & 0.0131 & 13.3 & 12.8 & 0.0012 & 25.7 \\
\hline
\end{tabular}




\begin{tabular}{|c|c|c|c|c|c|c|c|c|c|c|}
\hline \multirow{2}{*}{ Cobbles } & \multicolumn{4}{|c|}{ Gravel } & \multicolumn{4}{c|}{ Sand } & \multicolumn{3}{c|}{ Fines } \\
\cline { 2 - 12 } & Coarse & Fine & Total & Coarse & Medium & Fine & Total & Silt & Clay & Total \\
\hline 0.0 & 0.0 & 0.0 & 0.0 & 0.0 & 0.2 & 0.5 & 0.7 & 63.9 & 35.4 & 99.3 \\
\hline
\end{tabular}

\begin{tabular}{|c|c|c|c|c|c|c|c|c|c|c|c|}
\hline $\mathrm{D}_{\mathbf{5}}$ & $\mathrm{D}_{\mathbf{1 0}}$ & $\mathrm{D}_{\mathbf{1 5}}$ & $\mathrm{D}_{\mathbf{2 0}}$ & $\mathrm{D}_{\mathbf{3 0}}$ & $\mathrm{D}_{\mathbf{4 0}}$ & $\mathrm{D}_{\mathbf{5 0}}$ & $\mathrm{D}_{\mathbf{6 0}}$ & $\mathrm{D}_{\mathbf{8 0}}$ & $\mathrm{D}_{\mathbf{8 5}}$ & $\mathrm{D}_{\mathbf{9 0}}$ & $\mathrm{D}_{\mathbf{9 5}}$ \\
\hline & & & & 0.0023 & 0.0071 & 0.0132 & 0.0186 & 0.0290 & 0.0332 & 0.0393 & 0.0497 \\
\hline
\end{tabular}

Fineness

Modulus

0.00 


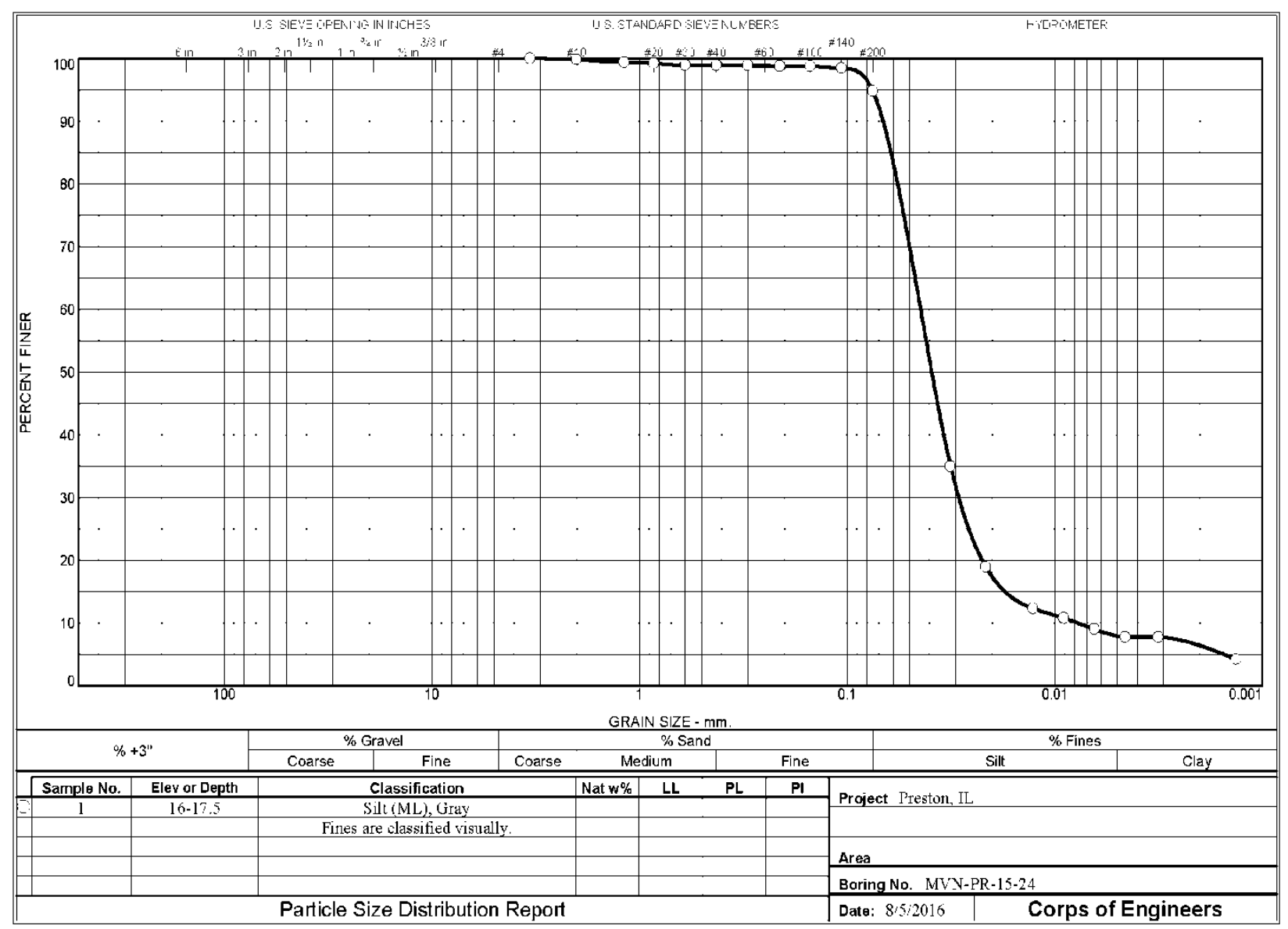

ENG 1 FORM 2087

Tested By: AT/FAN

Checked By: TRJ 
Project: Preston, IL

Location: MVN-PR-15-24

Depth: $16-17.5$

Sample Number: 1

Material Description: Silt (ML), Gray

Tested by: AT/FAN

Fines are classified visually.

\begin{tabular}{|c|c|c|c|c|c|c|c|c|}
\hline & & & & & & & & \\
\hline & & & & Sieve Te: & st Data & & & \\
\hline $\begin{array}{c}\text { Dry } \\
\text { Sample } \\
\text { and Tare } \\
\text { (grams) }\end{array}$ & $\begin{array}{c}\text { Tare } \\
\text { (grams) }\end{array}$ & $\begin{array}{l}\text { Cumulative } \\
\text { Pan } \\
\text { Tare Weight } \\
\text { (grams) }\end{array}$ & $\begin{array}{r}\mathrm{Sie} \\
\text { Ope } \\
\mathrm{Si}\end{array}$ & & $\begin{array}{l}\text { umulative } \\
\text { Weight } \\
\text { Retained } \\
\text { (grams) }\end{array}$ & $\begin{array}{l}\text { Percent } \\
\text { Finer }\end{array}$ & & \\
\hline 138.00 & 0.00 & 0.00 & & $\# 6$ & 0.00 & 100.0 & & \\
\hline & & & & $\$ 10$ & 0.20 & 99.9 & & \\
\hline 65.50 & 0.00 & 0.00 & & 416 & 0.30 & 99.4 & & \\
\hline & & & & 420 & 0.40 & 99.2 & & \\
\hline & & & & 430 & 0.60 & 98.9 & & \\
\hline & & & & 440 & 0.60 & 98.9 & & \\
\hline & & & & 450 & 0.60 & 98.9 & & \\
\hline & & & & 470 & 0.70 & 98.8 & & \\
\hline & & & & 100 & 0.70 & 98.8 & & \\
\hline & & & & 140 & 0.90 & 98.5 & & \\
\hline & & & & 200 & 3.30 & 94.8 & & \\
\hline & & & & drometer & Test Dat & & & \\
\hline $\begin{array}{l}\text { Hydrometer tes } \\
\text { Percent passin } \\
\text { Weight of hydr } \\
\text { Automatic tem } \\
\text { Composite } \\
\text { Meniscus corre } \\
\text { Specific gravit } \\
\text { Hydrometer ty } \\
\text { Hydrometer }\end{array}$ & $\begin{array}{l}\text { t uses mater } \\
\text { \#10 based } \\
\text { meter samp } \\
\text { erature corr } \\
\text { rrection (flu } \\
\text { ction only = } \\
\text { of solids = } \\
e=151 \mathrm{H} \\
\text { ffective dep }\end{array}$ & $\begin{array}{l}\text { ial passing } \# 1 \\
\text { upon complet } \\
\text { le }=62.5 \\
\text { cction } \\
\text { id density and } \\
-0.5 \\
69 \text { est } \\
\text { h equation: L }\end{array}$ & $\begin{array}{l}0 \\
\text { e sample }=9 \\
\text { meniscus } \mathrm{h} \\
=16.294964\end{array}$ & $\begin{array}{l}\text { ight) at } 20 \\
-0.2645 \mathrm{x}\end{array}$ & $\begin{array}{l}0 \text { deg. } C= \\
\times \mathrm{Rm}\end{array}$ & -4.7 & & \\
\hline $\begin{array}{l}\text { Elapsed } \\
\text { Time (min.) }\end{array}$ & $\begin{array}{l}\text { Temp. } \\
\text { (deg. C.) }\end{array}$ & $\begin{array}{c}\text { Actual } \\
\text { Reading }\end{array}$ & $\begin{array}{l}\text { Corrected } \\
\text { Reading }\end{array}$ & $\mathrm{K}$ & Rm & $\begin{array}{l}\text { Eff. } \\
\text { Depth }\end{array}$ & $\begin{array}{l}\text { Diameter } \\
(\mathrm{mm} .)\end{array}$ & $\begin{array}{l}\text { Percent } \\
\text { Finer }\end{array}$ \\
\hline 2.00 & 22.0 & 1.0182 & 1.0138 & 0.0132 & 17.7 & 11.6 & 0.0317 & 350 \\
\hline 5.00 & 22.0 & 1.0119 & 1.0075 & 0.0132 & 11.4 & 13.3 & 0.0214 & 19.0 \\
\hline 15.00 & 22.0 & 1.0093 & 1.0049 & 0.0132 & 8.8 & 14.0 & 0.0127 & 12.3 \\
\hline 30.00 & 22.0 & 1.0087 & 1.0043 & 0.0132 & 8.2 & 14.1 & 0.0090 & 10.8 \\
\hline 60.00 & 22.0 & 1.0080 & 1.0036 & 0.0132 & 7.5 & 14.3 & 0.0064 & 9.0 \\
\hline 120.00 & 22.0 & 1.0075 & 1.0031 & 0.0132 & 7.0 & 14.4 & 0.0046 & 7.8 \\
\hline 250.00 & 22.0 & 1.0075 & 1.0031 & 0.0132 & 7.0 & 14.4 & 0.0032 & 7.8 \\
\hline 1440.00 & 22.0 & 1.0061 & 1.0017 & 0.0132 & 5.6 & 14.8 & 0.0013 & 4.2 \\
\hline
\end{tabular}




\begin{tabular}{|c|c|c|c|c|c|c|c|c|c|c|c|c|}
\hline \multicolumn{13}{|c|}{ Fractional Components } \\
\hline \multirow{2}{*}{ Cobbles } & \multicolumn{3}{|c|}{ Gravel } & \multicolumn{6}{|c|}{ Sand } & \multicolumn{3}{|c|}{ Fines } \\
\hline & Coarse & Fine & Total & \multicolumn{2}{|c|}{ Coarse } & \multicolumn{2}{|c|}{ Medium } & Fine & \multirow{2}{*}{$\begin{array}{c}\text { Total } \\
5.2\end{array}$} & \multirow{2}{*}{$\begin{array}{c}\text { Silt } \\
86.8\end{array}$} & Clay & Total \\
\hline 0.0 & 0.0 & 0.0 & 0.0 & 0.1 & & 1.0 & & 4.1 & & & 8.0 & 94.8 \\
\hline $\mathrm{D}_{5}$ & $\mathrm{D}_{10}$ & $\mathrm{D}_{15}$ & $\mathrm{D}_{20}$ & $\mathrm{D}_{30}$ & $\mathrm{D}_{4}$ & & $\mathrm{D}_{5 \mathrm{C}}$ & & $\mathrm{D}_{80}$ & $D_{85}$ & $\mathrm{D}_{90}$ & $D_{95}$ \\
\hline 0.0015 & 0.0077 & 0.0173 & 0.0223 & 0.0290 & 0.03 & & 0.03 & & 0.0570 & 0.0614 & 0.0669 & 0.0754 \\
\hline
\end{tabular}

\begin{tabular}{|c|c|c|}
\hline $\begin{array}{c}\text { Fineness } \\
\text { Modulus }\end{array}$ & $\mathrm{c}_{\mathbf{u}}$ & $\mathrm{c}_{\mathbf{c}}$ \\
\hline 0.04 & 5.75 & 2.47 \\
\hline
\end{tabular}




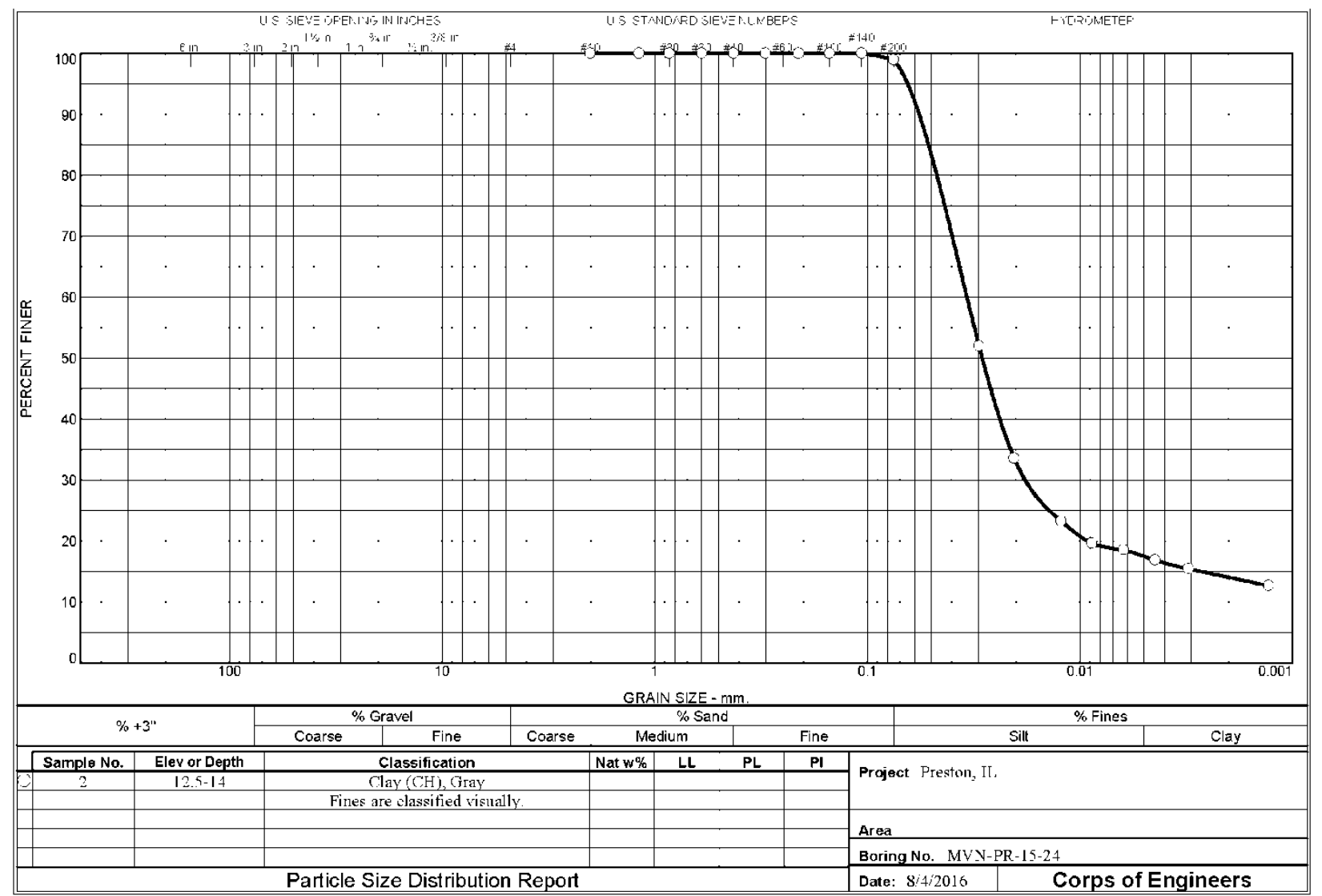

ENG 1 MORM 2087

Tested By: AT/FAN

Checked By: TRJ 
Project: Preston, IL

Location: MVN-PR-15-24

Depth: $12.5-14$

Sample Number: 2

Material Description: Clay (CH), Gray

Fines are classified visually.

Tested by: AT/FAN

Checked by: TRJ

\begin{tabular}{|c|c|c|c|c|c|}
\hline \multicolumn{6}{|c|}{ Sieve Test Data } \\
\hline $\begin{array}{c}\text { Dry } \\
\text { Sample } \\
\text { and Tare } \\
\text { (grams) }\end{array}$ & $\begin{array}{c}\text { Tare } \\
\text { (grams) }\end{array}$ & $\begin{array}{c}\text { Cumulative } \\
\text { Pan } \\
\text { Tare Weight } \\
\text { (grams) }\end{array}$ & $\begin{array}{c}\text { Sieve } \\
\text { Opening } \\
\text { Size }\end{array}$ & $\begin{array}{c}\text { Cumulative } \\
\text { Weight } \\
\text { Retained } \\
\text { (grams) }\end{array}$ & $\begin{array}{l}\text { Percent } \\
\text { Finer }\end{array}$ \\
\hline \multirow[t]{10}{*}{57.00} & 0.00 & 0.00 & $\# 10$ & 0.00 & 100.0 \\
\hline & & & $\# 16$ & 0.00 & 100.0 \\
\hline & & & $\# 20$ & 0.00 & 100.0 \\
\hline & & & $\# 30$ & 0.00 & 100.0 \\
\hline & & & $\# 40$ & 0.00 & 100.0 \\
\hline & & & $\# 50$ & 0.00 & 100.0 \\
\hline & & & $\# 70$ & 0.00 & 100.0 \\
\hline & & & $\# 100$ & 0.00 & 100.0 \\
\hline & & & $\# 140$ & 0.00 & 100.0 \\
\hline & & & $\# 200$ & 0.60 & 98.9 \\
\hline
\end{tabular}

Hydrometer test uses material passing $\# 10$

Hydrometer Test Data

Percent passing $\# 10$ based upon complete sample $=100.0$

Weight of hydrometer sample $=57.0$

Automatic temperature correction

Composite correction (fluid density and meniscus height) at $\mathbf{2 0}$ deg. $\mathrm{C}=-4.7$

Meniscus correction only $=-0.5$

Specific gravity of solids $=2.70$ est

Hydrometer type $=151 \mathrm{H}$

Hydrometer effective depth equation: $L=16.294964-0.2645 \times \mathbf{R m}$

$\begin{array}{ccccccccc}\begin{array}{c}\text { Elapsed } \\ \text { Time (min.) }\end{array} & \begin{array}{c}\text { Temp. } \\ \text { (deg. C.) }\end{array} & \begin{array}{c}\text { Actual } \\ \text { Reading }\end{array} & \begin{array}{c}\text { Corrected } \\ \text { Reading }\end{array} & \mathbf{K} & \mathbf{R m} & \begin{array}{c}\text { Eff. } \\ \text { Depth }\end{array} & \begin{array}{c}\text { Diameter } \\ (\mathbf{m m} \text { ) }\end{array} & \begin{array}{c}\text { Percent } \\ \text { Finer }\end{array} \\ 2.00 & 22.0 & 1.0231 & 1.0187 & 0.0131 & 22.6 & 10.3 & 0.0298 & 52.0 \\ 5.00 & 22.0 & 1.0165 & 1.0121 & 0.0131 & 16.0 & 12.1 & 0.0204 & 33.6 \\ 15.00 & 22.0 & 1.0128 & 1.0084 & 0.0131 & 12.3 & 13.0 & 0.0122 & 23.3 \\ 30.00 & 22.0 & 1.0115 & 1.0071 & 0.0131 & 11.0 & 13.4 & 0.0088 & 19.6 \\ 60.00 & 22.0 & 1.0111 & 1.0067 & 0.0131 & 10.6 & 13.5 & 0.0062 & 18.5 \\ 120.00 & 22.0 & 1.0105 & 1.0061 & 0.0131 & 10.0 & 13.6 & 0.0044 & 16.9 \\ 250.00 & 22.0 & 1.0100 & 1.0056 & 0.0131 & 9.5 & 13.8 & 0.0031 & 15.5 \\ 1440.00 & 22.0 & 1.0090 & 1.0046 & 0.0131 & 8.5 & 14.0 & 0.0013 & 12.7\end{array}$




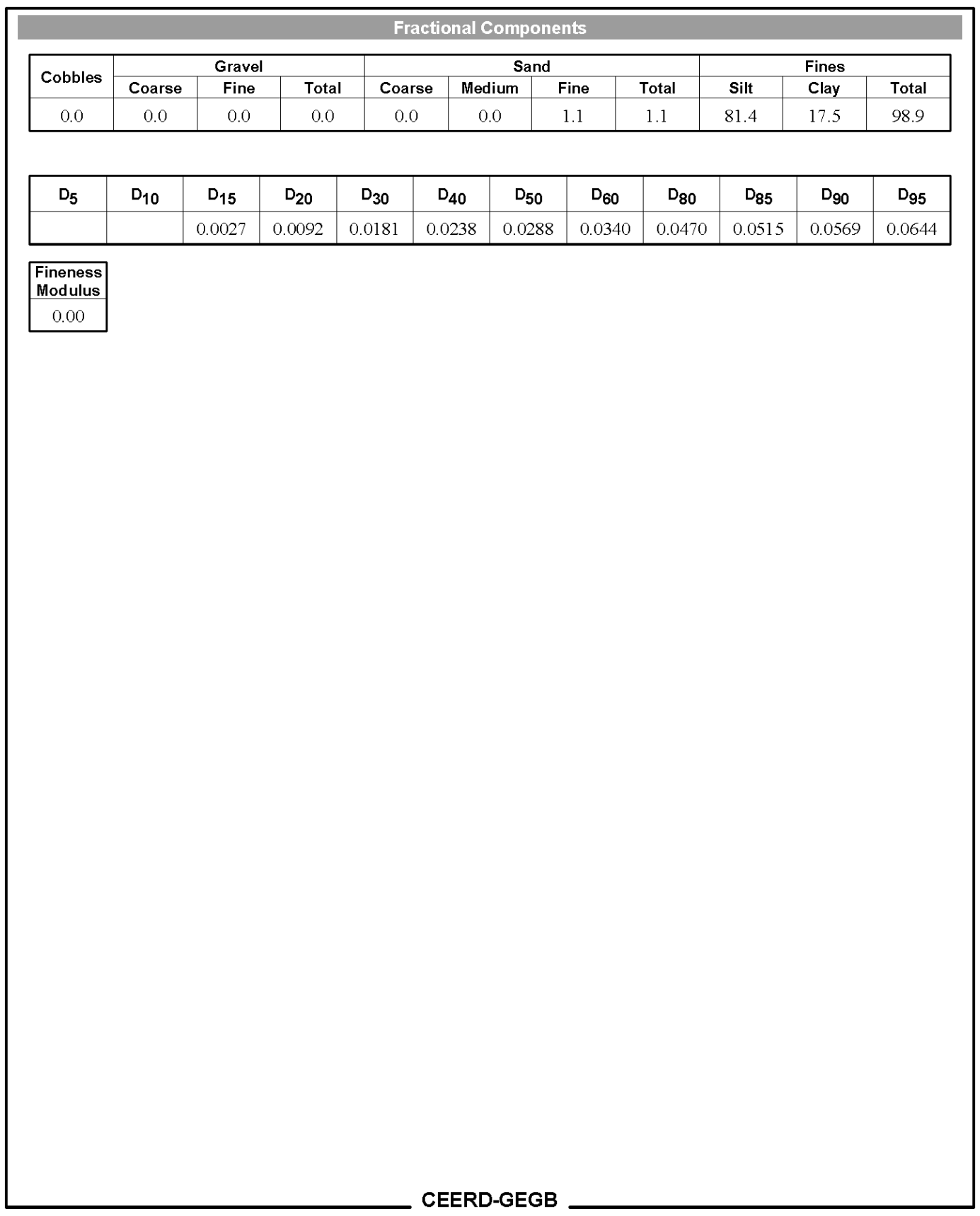




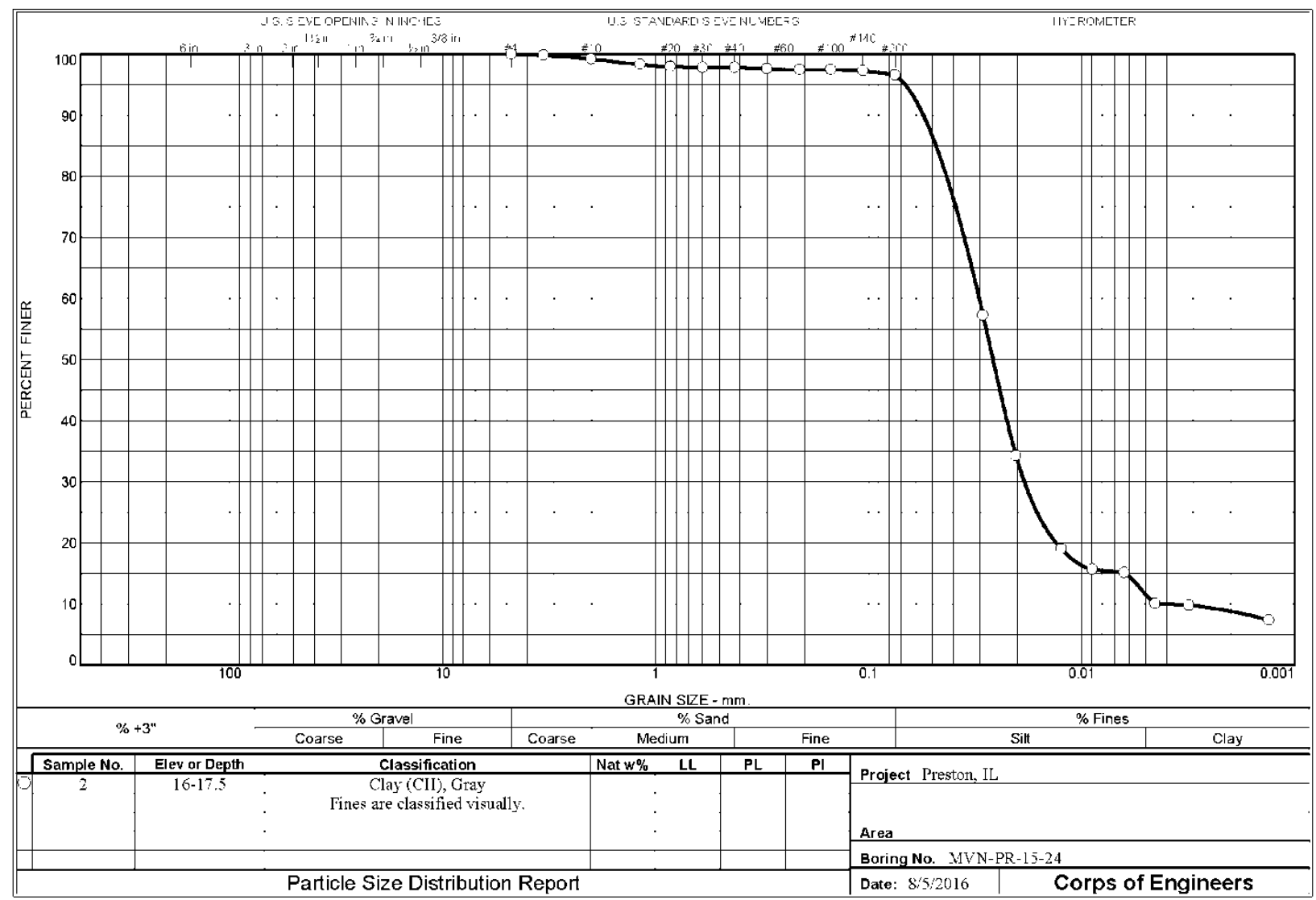

ENG 1 1 MAYM 203087

Tested By: AT/FAN

Checked By: TRJ 
Project: Preston, IL

Location: MVN-PR-15-24

Depth: 16-17.5

Sample Number: 2

Material Description: Clay (CH), Gray

Tested by: AT/FAN

Fines are classified visually.

\begin{tabular}{|c|c|c|c|c|c|}
\hline & & & & & \\
\hline & & & Siev & Test Data & \\
\hline $\begin{array}{c}\text { Dry } \\
\text { Sample } \\
\text { and Tare } \\
\text { (grams) }\end{array}$ & $\begin{array}{c}\text { Tare } \\
\text { (grams) }\end{array}$ & $\begin{array}{c}\text { Cumulative } \\
\text { Pan } \\
\text { Tare Weight } \\
\text { (grams) }\end{array}$ & $\begin{array}{l}\text { Sieve } \\
\text { Opening } \\
\text { Size }\end{array}$ & $\begin{array}{c}\text { Cumulative } \\
\text { Weight } \\
\text { Retained } \\
\text { (grams) }\end{array}$ & $\begin{array}{l}\text { Percent } \\
\text { Finer }\end{array}$ \\
\hline 113.70 & 0.00 & 0.00 & $\# 4$ & 0.00 & 100.0 \\
\hline & & & $\# 6$ & 0.20 & 99.8 \\
\hline & & & $\# 10$ & 0.90 & 99.2 \\
\hline 56.80 & 0.00 & 0.00 & $\# 16$ & 0.50 & 98.3 \\
\hline & & & $\# 20$ & 0.70 & 98.0 \\
\hline & & & $\# 30$ & 0.80 & 97.8 \\
\hline & & & $\# 40$ & 0.80 & 97.8 \\
\hline & & & $\# 50$ & 0.90 & 97.6 \\
\hline & & & $\# 70$ & 1.00 & 97.5 \\
\hline & & & $\# 100$ & 1.00 & 97.5 \\
\hline & & & $\# 140$ & 1.10 & 97.3 \\
\hline & & & $\# 200$ & 1.50 & 96.6 \\
\hline & & & Hydro & Test Dat & \\
\hline
\end{tabular}

Hydrometer test uses material passing $\# 10$

Percent passing \#10 based upon complete sample $=99.2$

Weight of hydrometer sample $=56.8$

Automatic temperature correction

Composite correction (fluid density and meniscus height) at $\mathbf{2 0}$ deg. $C=-4.7$

Meniscus correction only $=-0.5$

Specific gravity of solids $=2.70$ est

Hydrometer type $=151 \mathrm{H}$

Hydrometer effective depth equation: $L=16.294964-0.2645 \times \mathbf{R m}$

$\begin{array}{ccccccccc}\begin{array}{c}\text { Elapsed } \\ \text { Time (min.) }\end{array} & \begin{array}{c}\text { Temp. } \\ \text { (deg. C.) }\end{array} & \begin{array}{c}\text { Actual } \\ \text { Reading }\end{array} & \begin{array}{c}\text { Corrected } \\ \text { Reading }\end{array} & \mathbf{K} & \mathbf{R m} & \begin{array}{c}\text { Eff. } \\ \text { Depth }\end{array} & \begin{array}{c}\text { Diameter } \\ (\mathbf{m m} \text { ) }\end{array} & \begin{array}{c}\text { Percent } \\ \text { Finer }\end{array} \\ 2.00 & 22.0 & 1.0251 & 1.0207 & 0.0131 & 24.6 & 9.8 & 0.0290 & 57.3 \\ 5.00 & 22.0 & 1.0168 & 1.0124 & 0.0131 & 16.3 & 12.0 & 0.0203 & 34.3 \\ 15.00 & 22.0 & 1.0113 & 1.0069 & 0.0131 & 10.8 & 13.4 & 0.0124 & 19.0 \\ 30.00 & 22.0 & 1.0101 & 1.0057 & 0.0131 & 9.6 & 13.8 & 0.0089 & 15.7 \\ 60.00 & 22.0 & 1.0099 & 1.0055 & 0.0131 & 9.4 & 13.8 & 0.0063 & 15.1 \\ 120.00 & 22.5 & 1.0080 & 1.0036 & 0.0130 & 7.5 & 14.3 & 0.0045 & 10.1 \\ 250.00 & 22.5 & 1.0079 & 1.0035 & 0.0130 & 7.4 & 14.3 & 0.0031 & 9.8 \\ 1440.00 & 22.0 & 1.0071 & 1.0027 & 0.0131 & 6.6 & 14.5 & 0.0013 & 7.4\end{array}$




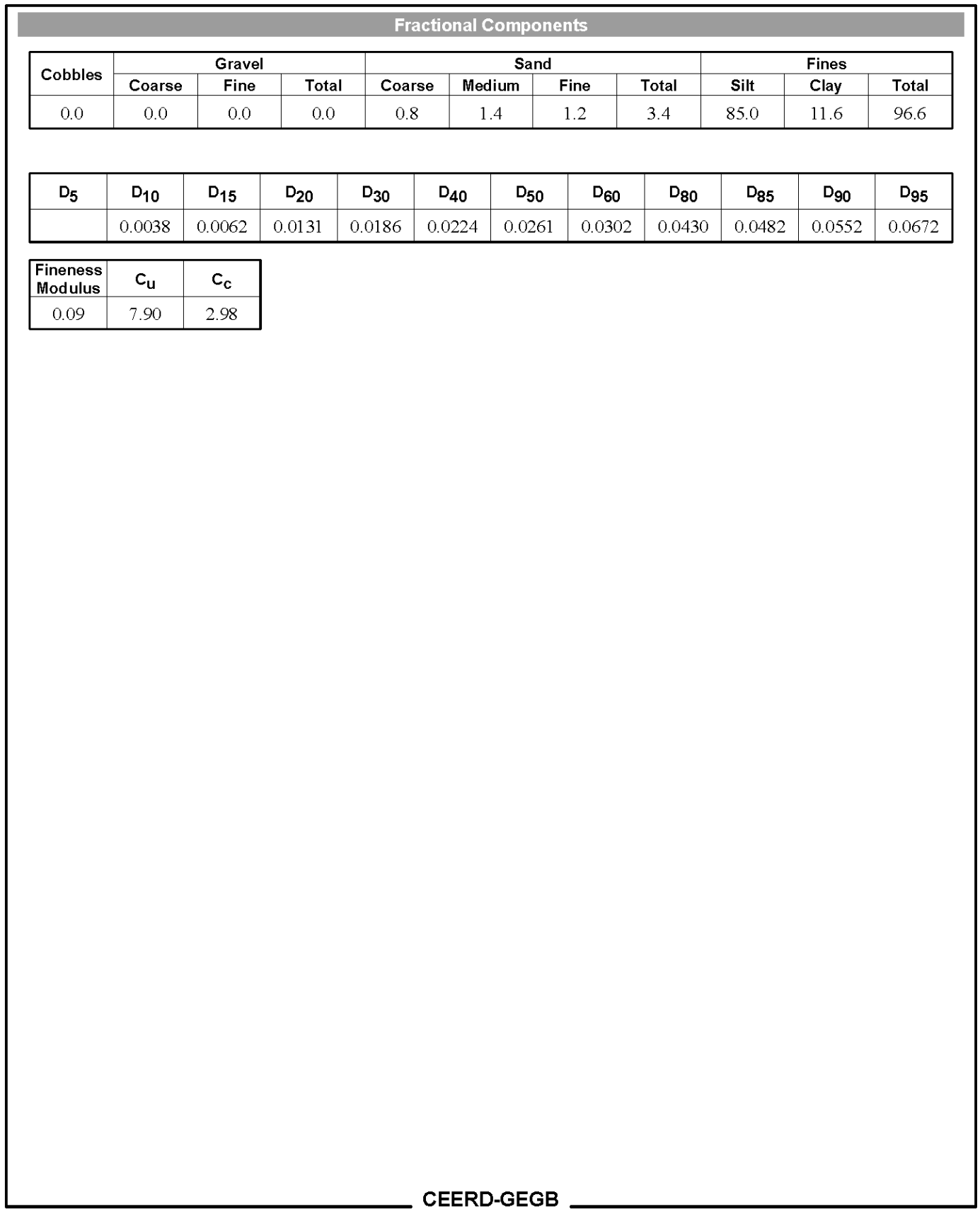




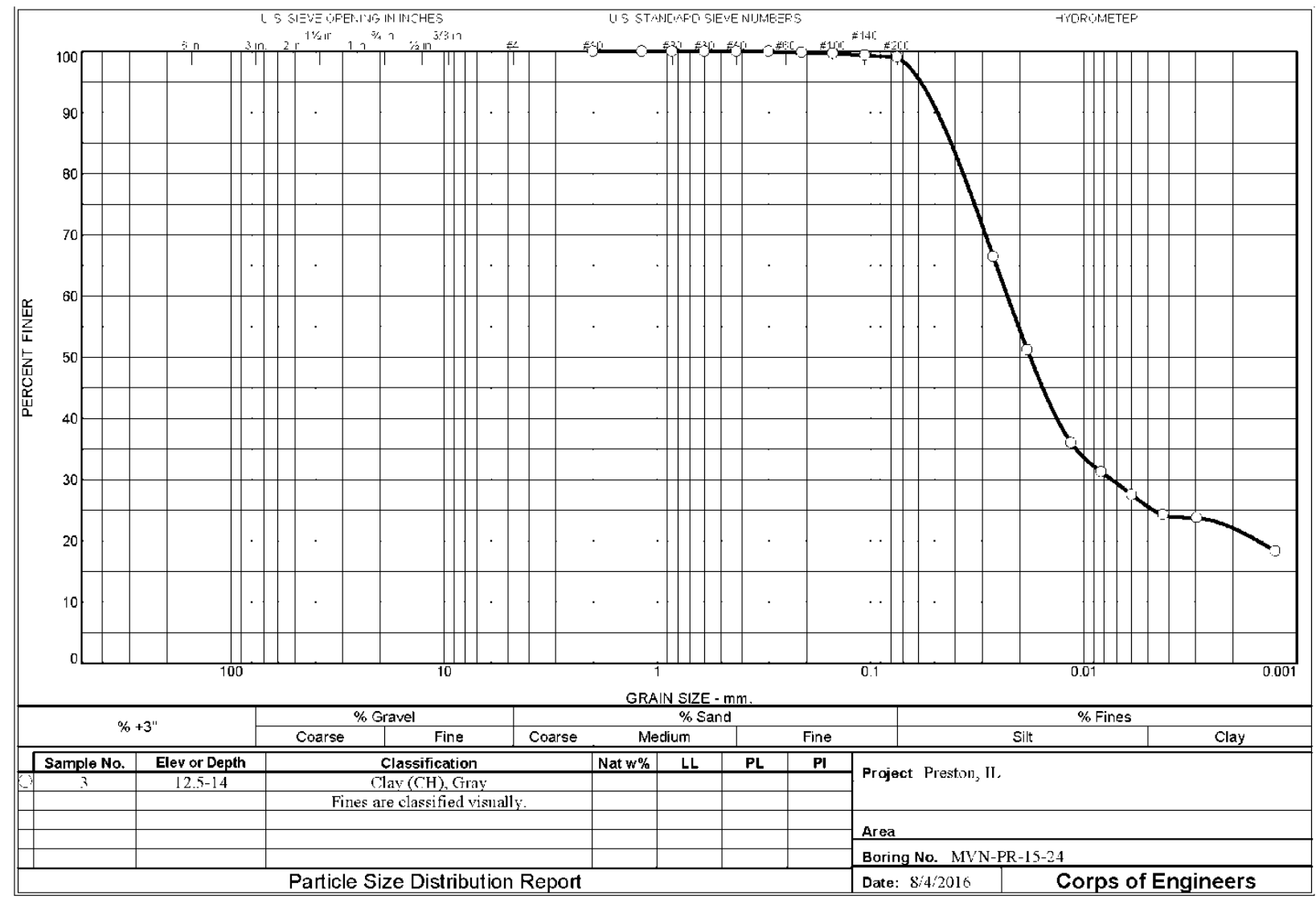

ENG 1 FORM 2087

Tested By: AT/FAN

Checked By: TRJ 
GRAIN SIZE DISTRIBUTION TEST DATA

8/4/2016

Project: Preston, IL

Location: MVN-PR-15-24

Depth: $12.5-14$

Sample Number: 3

Material Description: Clay $(\mathrm{CH})$, Gray

Fines are classified visually

Tested by: AT/FAN

Checked by: TRJ

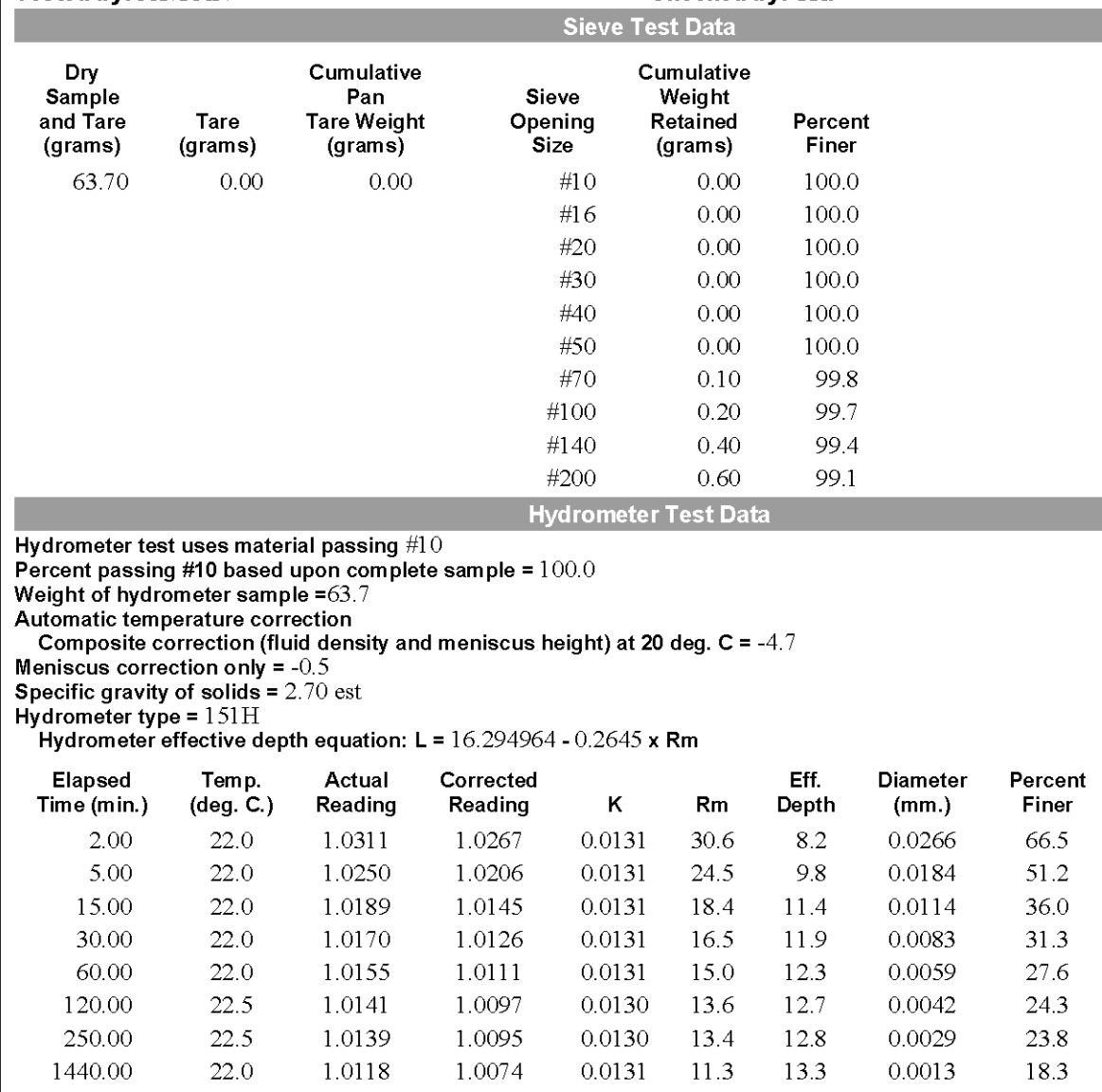




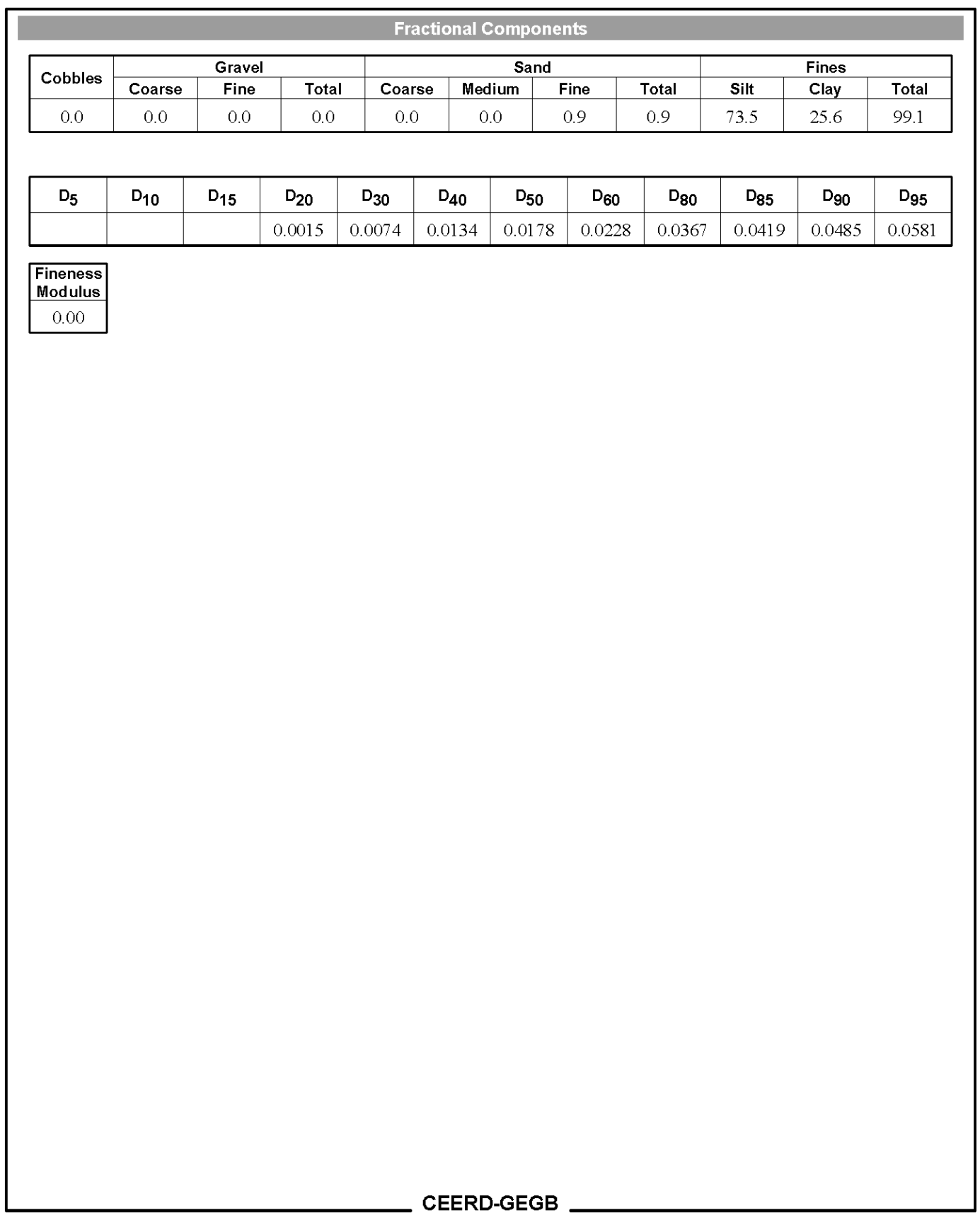




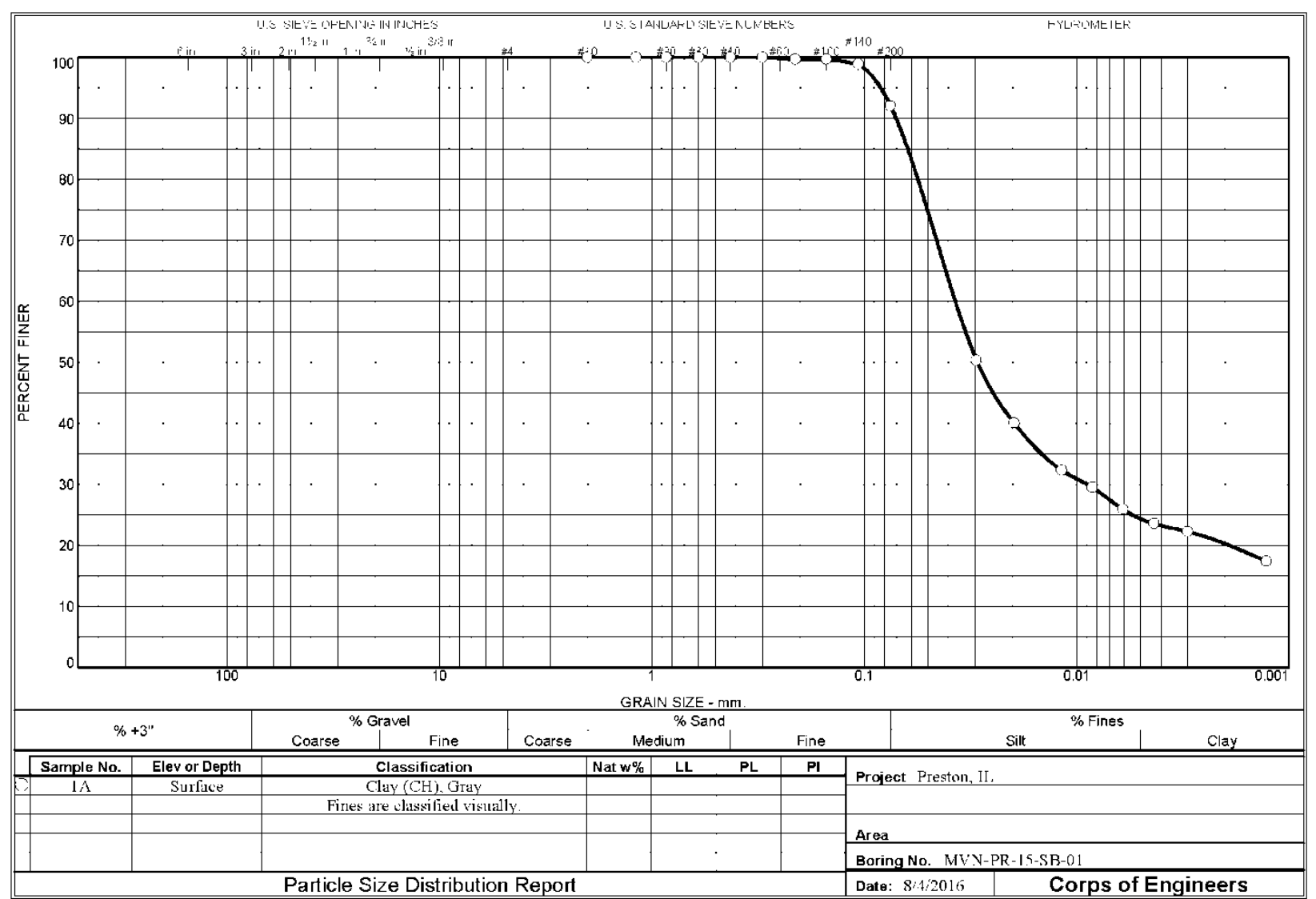

ENG 1 FORM 2087

Tested By: AT/FAN

Checked By: TRJ 
Project: Preston, IL

Location: MVN-PR-15-SB-01

Depth: Surface

Sample Number: 1A

Material Description: Clay $(\mathrm{CH})$, Gray

Fines are classified visually.

Tested by: AT/FAN

Checked by: TRJ

\begin{tabular}{|c|c|c|c|c|c|c|c|c|}
\hline & & & & & & & & \\
\hline & & & & Sieve Te & st Data & & & \\
\hline $\begin{array}{c}\text { Dry } \\
\text { Sample } \\
\text { and Tare } \\
\text { (grams) }\end{array}$ & $\begin{array}{c}\text { Tare } \\
\text { (grams) }\end{array}$ & $\begin{array}{c}\text { Cumulative } \\
\text { Pan } \\
\text { Tare Weight } \\
\text { (grams) }\end{array}$ & $\begin{array}{l}\mathrm{Sie} \\
\text { Oper } \\
\mathrm{Si}\end{array}$ & & $\begin{array}{l}\text { umulative } \\
\text { Weight } \\
\text { Retained } \\
\text { (grams) }\end{array}$ & $\begin{array}{l}\text { Percent } \\
\text { Finer }\end{array}$ & & \\
\hline 61.80 & 0.00 & 0.00 & & 10 & 0.00 & 100.0 & & \\
\hline & & & & 16 & 0.00 & 100.0 & & \\
\hline & & & & 20 & 0.00 & 100.0 & & \\
\hline & & & & 30 & 0.00 & 100.0 & & \\
\hline & & & & 40 & 0.00 & 100.0 & & \\
\hline & & & & 50 & 0.00 & 100.0 & & \\
\hline & & & & 70 & 0.20 & 99.7 & & \\
\hline & & & & 00 & 0.20 & 99.7 & & \\
\hline & & & & 40 & 0.70 & 98.9 & & \\
\hline & & & & 00 & 4.90 & 92.1 & & \\
\hline & & & & rometer & Test Da & & & \\
\hline $\begin{array}{l}\text { Hydrometer tes } \\
\text { Percent passin } \\
\text { Weight of hydr } \\
\text { Automatic tem } \\
\text { Composite c } \\
\text { Meniscus corre } \\
\text { Specific gravit } \\
\text { Hydrometer ty } \\
\text { Hydrometer }\end{array}$ & $\begin{array}{l}t \text { uses mate } \\
\# 10 \text { based } \\
\text { meter samp } \\
\text { erature corr } \\
\text { rrection (fll } \\
\text { ction only = } \\
\text { of solids = } \\
e=151 \mathrm{H} \\
\text { ffective dep }\end{array}$ & $\begin{array}{l}\text { al passing } \# 1 \\
\text { upon complet } \\
\mathrm{e}=61.8 \\
\text { ection } \\
\text { id density and } \\
0.5 \\
69 \text { est } \\
\mathrm{h} \text { equation: L }\end{array}$ & $\begin{array}{l}0 \\
\text { meniscus } \mathrm{h} \\
=16.294964\end{array}$ & ght) at 20 & $\begin{array}{l}\mathrm{deg} . \\
\mathrm{Rm}\end{array}$ & -4.7 & & \\
\hline $\begin{array}{c}\text { Elapsed } \\
\text { Time (min.) }\end{array}$ & $\begin{array}{c}\text { Temp. } \\
\text { (deg. C.) }\end{array}$ & $\begin{array}{l}\text { Actual } \\
\text { Reading }\end{array}$ & $\begin{array}{l}\text { Corrected } \\
\text { Reading }\end{array}$ & $\mathrm{K}$ & Rm & $\begin{array}{c}\text { Eff. } \\
\text { Depth }\end{array}$ & $\begin{array}{c}\text { Diameter } \\
(\mathrm{mm} .)\end{array}$ & $\begin{array}{l}\text { Percent } \\
\text { Finer }\end{array}$ \\
\hline 2.00 & 22.0 & 1.0240 & 1.0196 & 0.0132 & 23.5 & 10.1 & 0.0295 & 50.4 \\
\hline 5.00 & 22.0 & 1.0200 & 1.0156 & 0.0132 & 19.5 & 11.1 & 0.0196 & 40.1 \\
\hline 15.00 & 22.0 & 1.0170 & 1.0126 & 0.0132 & 16.5 & 11.9 & 0.0117 & 32.3 \\
\hline 30.00 & 22.0 & 1.0159 & 1.0115 & 0.0132 & 15.4 & 12.2 & 0.0084 & 29.5 \\
\hline 60.00 & 22.0 & 1.0145 & 1.0101 & 0.0132 & 14.0 & 12.6 & 0.0060 & 25.9 \\
\hline 120.00 & 22.0 & 1.0136 & 1.0092 & 0.0132 & 13.1 & 12.8 & 0.0043 & 23.6 \\
\hline 250.00 & 22.0 & 1.0131 & 1.0087 & 0.0132 & 12.6 & 13.0 & 0.0030 & 22.3 \\
\hline 1440.00 & 22.0 & 1.0112 & 1.0068 & 0.0132 & 10.7 & 13.5 & 0.0013 & 17.4 \\
\hline
\end{tabular}




\begin{tabular}{|c|c|c|c|c|c|c|c|c|c|c|c|c|c|}
\hline \multicolumn{14}{|c|}{ Fractional Components } \\
\hline \multirow{2}{*}{ Cobbles } & \multicolumn{3}{|c|}{ Gravel } & \multicolumn{7}{|c|}{ Sand } & \multicolumn{3}{|c|}{ Fines } \\
\hline & Coarse & Fine & Total & \multicolumn{2}{|c|}{ Coarse } & \multicolumn{2}{|c|}{ Medium } & \multicolumn{2}{|c|}{ Fine } & Total & Silt & \multirow{2}{*}{$\begin{array}{l}\text { Clay } \\
24.4\end{array}$} & Total \\
\hline 0.0 & 0.0 & 0.0 & 0.0 & 0.0 & & 0.0 & & 7. & & 7.9 & 67.7 & & 92.1 \\
\hline$D_{5}$ & $\mathrm{D}_{10}$ & $D_{15}$ & $\mathrm{D}_{20}$ & $\mathrm{D}_{30}$ & $\mathrm{D}_{4}$ & & $\mathrm{D}_{5 \mathrm{C}}$ & & $\mathrm{D}_{60}$ & $D_{80}$ & $D_{85}$ & $\mathrm{D}_{90}$ & $D_{95}$ \\
\hline & & & 0.0019 & 0.0089 & 0.01 & & 0.02 & & 0.0372 & 0.0558 & 0.0622 & 0.0706 & 0.0833 \\
\hline
\end{tabular}

Fineness

Modulus

0.00 


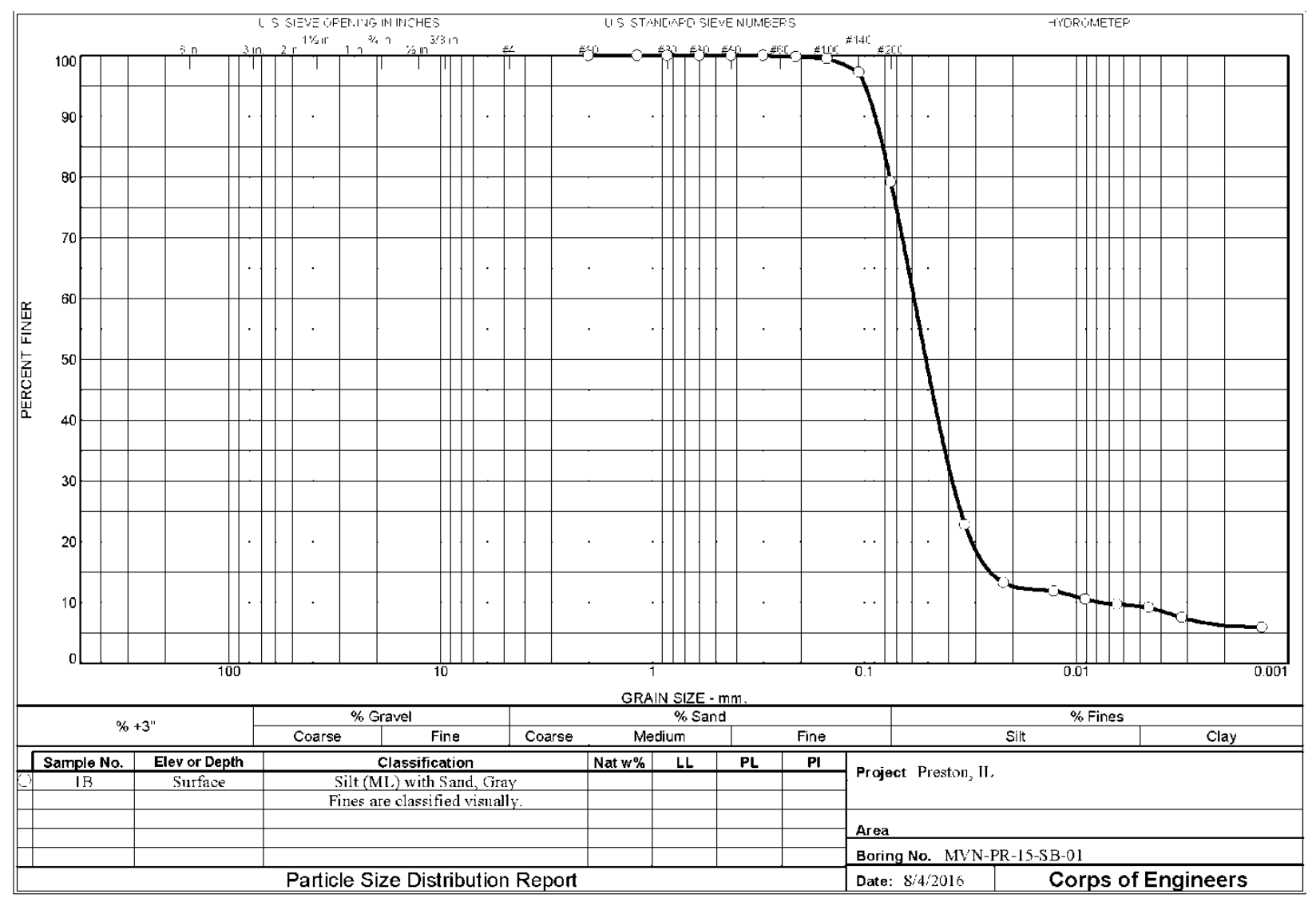

ENG 1 MORM 2087

Tested By: ATIFAN

Checked By: TRJ 
GRAIN SIZE DISTRIBUTION TEST DATA

$8 / 4 / 2016$

Project: Preston, IL

Location: MVN-PR-15-SB-01

Depth: Surface

Sample Number: 1B

Material Description: Silt (ML) with Sand, Gray

Tested by: AT/FAN Fines are classified visually.

\begin{tabular}{|c|c|c|c|c|c|}
\hline & & & & & \\
\hline & & & Siev & Test Data & \\
\hline $\begin{array}{c}\text { Dry } \\
\text { Sample } \\
\text { and Tare } \\
\text { (grams) }\end{array}$ & $\begin{array}{c}\text { Tare } \\
\text { (grams) }\end{array}$ & $\begin{array}{c}\text { Cumulative } \\
\text { Pan } \\
\text { Tare Weight } \\
\text { (grams) }\end{array}$ & $\begin{array}{l}\text { Sieve } \\
\text { Opening } \\
\text { Size }\end{array}$ & $\begin{array}{c}\text { Cumulative } \\
\text { Weight } \\
\text { Retained } \\
\text { (grams) }\end{array}$ & $\begin{array}{l}\text { Percent } \\
\text { Finer }\end{array}$ \\
\hline 58.20 & 0.00 & 0.00 & $\# 10$ & 0.00 & 100.0 \\
\hline & & & $\# 16$ & 0.00 & 100.0 \\
\hline & & & $\# 20$ & 0.00 & 100.0 \\
\hline & & & $\# 30$ & 0.00 & 100.0 \\
\hline & & & $\# 40$ & 0.00 & 100.0 \\
\hline & & & $\# 50$ & 0.00 & 100.0 \\
\hline & & & $\# 70$ & 0.10 & 99.8 \\
\hline & & & $\# 100$ & 0.30 & 99.5 \\
\hline & & & $\# 140$ & 1.60 & 97.3 \\
\hline & & & $\# 200$ & 12.10 & 79.2 \\
\hline
\end{tabular}

Hydrometer test uses material passing $\# 10$

Percent passing $\# 10$ based upon complete sample $=100.0$

Weight of hydrometer sample $=58.2$

Automatic temperature correction

Composite correction (fluid density and meniscus height) at $\mathbf{2 0}$ deg. $C=-4.7$

Meniscus correction only $=-0.5$

Specific gravity of solids $=2.69$ est

Hydrometer type $=151 \mathrm{H}$

Hydrometer effective depth equation: $L=16.294964-0.2645 \times \mathbf{R m}$

$\begin{array}{ccccccccc}\begin{array}{c}\text { Elapsed } \\ \text { Time (min.) }\end{array} & \begin{array}{c}\text { Temp. } \\ \text { (deg. C.) }\end{array} & \begin{array}{c}\text { Actual } \\ \text { Reading }\end{array} & \begin{array}{c}\text { Corrected } \\ \text { Reading }\end{array} & \mathbf{K} & \mathbf{R m} & \begin{array}{c}\text { Eff. } \\ \text { Depth }\end{array} & \begin{array}{c}\text { Diameter } \\ \text { (mm.) }\end{array} & \begin{array}{c}\text { Percent } \\ \text { Finer }\end{array} \\ 2.00 & 22.0 & 1.0128 & 1.0084 & 0.0132 & 12.3 & 13.0 & 0.0336 & 22.8 \\ 5.00 & 22.0 & 1.0093 & 1.0049 & 0.0132 & 8.8 & 14.0 & 0.0220 & 13.3 \\ 15.00 & 22.0 & 1.0088 & 1.0044 & 0.0132 & 8.3 & 14.1 & 0.0128 & 11.9 \\ 30.00 & 22.0 & 1.0083 & 1.0039 & 0.0132 & 7.8 & 14.2 & 0.0091 & 10.5 \\ 60.00 & 22.0 & 1.0080 & 1.0036 & 0.0132 & 7.5 & 14.3 & 0.0064 & 9.7 \\ 120.00 & 22.0 & 1.0078 & 1.0034 & 0.0132 & 7.3 & 14.4 & 0.0046 & 9.2 \\ 250.00 & 22.0 & 1.0072 & 1.0028 & 0.0132 & 6.7 & 14.5 & 0.0032 & 7.5 \\ 1440.00 & 22.0 & 1.0066 & 1.0022 & 0.0132 & 6.1 & 14.7 & 0.0013 & 5.9\end{array}$




\begin{tabular}{|c|c|c|c|c|c|c|c|c|c|c|c|c|c|}
\hline \multicolumn{14}{|c|}{ Fractional Components } \\
\hline \multirow{2}{*}{ Cobbles } & \multicolumn{3}{|c|}{ Gravel } & \multicolumn{7}{|c|}{ Sand } & \multicolumn{3}{|c|}{ Fines } \\
\hline & Coarse & Fine & Total & \multicolumn{2}{|c|}{ Coarse } & \multicolumn{2}{|c|}{ Medium } & \multicolumn{2}{|c|}{ Fine } & Total & Silt & \multirow{2}{*}{ Clay } & Total \\
\hline 0.0 & 0.0 & 0.0 & 0.0 & 0.0 & & 0 & & & 8 & 20.8 & 69.8 & & 79.2 \\
\hline$D_{5}$ & $\mathrm{D}_{10}$ & $\mathrm{D}_{15}$ & $\mathrm{D}_{20}$ & $\mathrm{D}_{30}$ & D & & $\mathrm{D}_{5}$ & & $D_{60}$ & $\mathrm{D}_{80}$ & $D_{85}$ & $\mathrm{D}_{90}$ & $\mathrm{D}_{95}$ \\
\hline & 0.0076 & 0.0255 & 0.0312 & 0.0385 & 0.0 & & 0.0 & & 0.0582 & 0.0759 & 0.0817 & 0.0890 & 0.0990 \\
\hline
\end{tabular}

\begin{tabular}{|c|c|c|}
\hline $\begin{array}{c}\text { Fineness } \\
\text { Modulus }\end{array}$ & $\mathrm{c}_{\mathbf{u}}$ & $\mathrm{c}_{\mathbf{c}}$ \\
\hline 0.01 & 7.67 & 3.36 \\
\hline
\end{tabular}




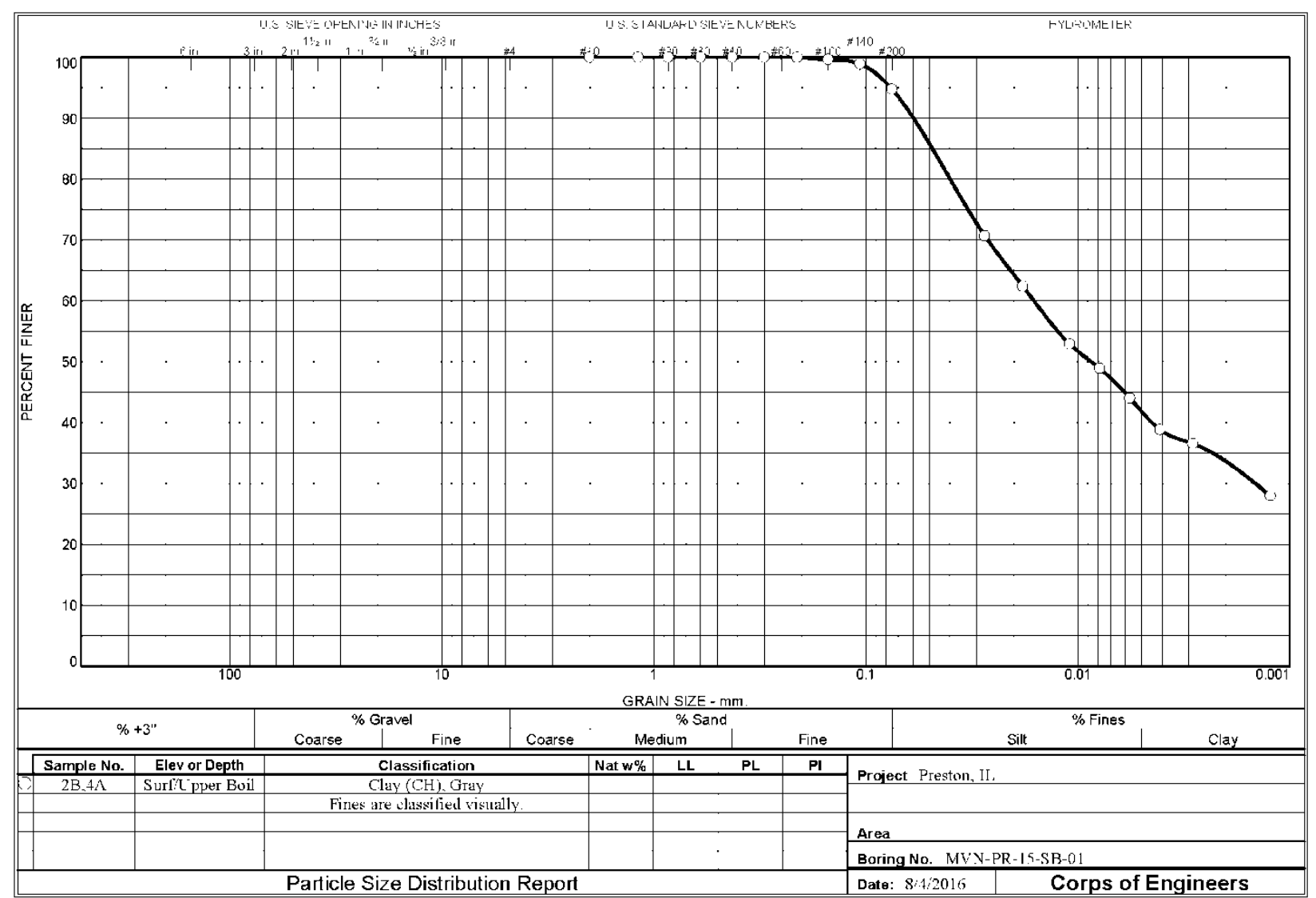

ENG 1 FORM 2087

Tested By: AT/FAN

Checked By: TRJ 
GRAIN SIZE DISTRIBUTION TEST DATA

$8 / 4 / 2016$

Project: Preston, IL

Location: MVN-PR-15-SB-01

Depth: Surf/Upper Boil

Material Description: Clay $(\mathrm{CH})$, Gray

Sample Number: 2B,4A

Fines are classified visually.

Tested by: AT/FAN

Checked by: TRJ

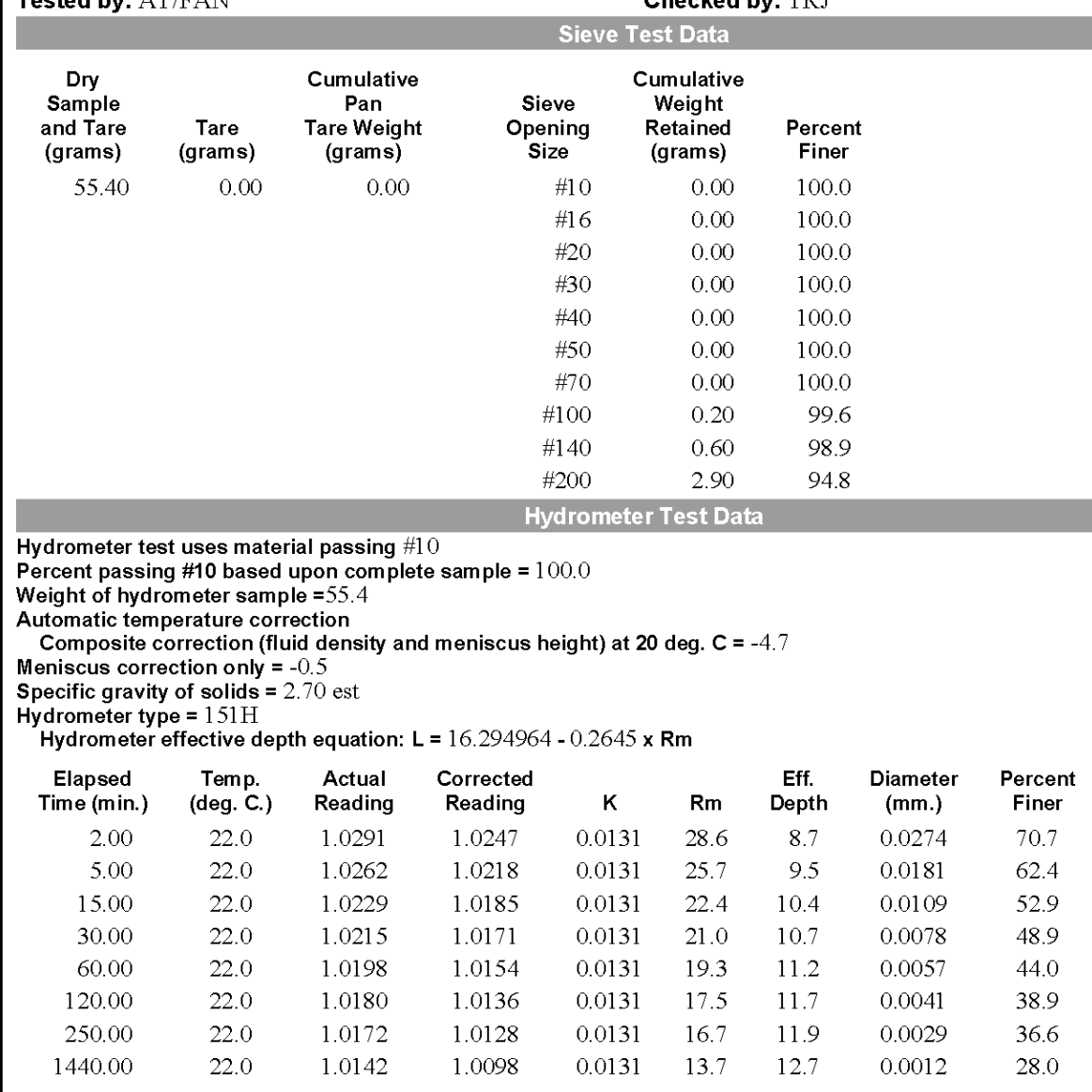




\begin{tabular}{|c|c|c|c|c|c|c|c|c|c|c|}
\hline \multicolumn{11}{|c|}{ Fractional Components } \\
\hline \multirow{2}{*}{ Cobbles } & \multicolumn{3}{|c|}{ Gravel } & \multicolumn{4}{|c|}{ Sand } & \multicolumn{3}{|c|}{ Fines } \\
\hline & Coarse & Fine & Total & Coarse & Medium & Fine & Total & Silt & Clay & Total \\
\hline 0.0 & 0.0 & 0.0 & 0.0 & 0.0 & 0.0 & 5.2 & 5.2 & 53.0 & 41.8 & 94.8 \\
\hline
\end{tabular}

\begin{tabular}{|c|c|c|c|c|c|c|c|c|c|c|c|}
\hline $\mathrm{D}_{\mathbf{5}}$ & $\mathrm{D}_{\mathbf{1 0}}$ & $\mathrm{D}_{\mathbf{1 5}}$ & $\mathrm{D}_{\mathbf{2 0}}$ & $\mathrm{D}_{\mathbf{3 0}}$ & $\mathrm{D}_{\mathbf{4 0}}$ & $\mathrm{D}_{\mathbf{5 0}}$ & $\mathrm{D}_{\mathbf{6 0}}$ & $\mathrm{D}_{\mathbf{8 0}}$ & $\mathrm{D}_{\mathbf{8 5}}$ & $\mathrm{D}_{\mathbf{9 0}}$ & $\mathrm{D}_{\mathbf{9 5}}$ \\
\hline & & & & 0.0014 & 0.0045 & 0.0086 & 0.0161 & 0.0400 & 0.0484 & 0.0594 & 0.0760 \\
\hline
\end{tabular}

Fineness

Modulus

0.00 


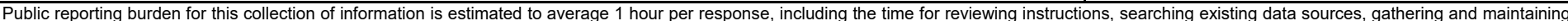

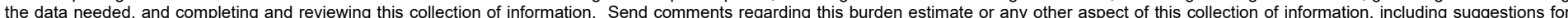

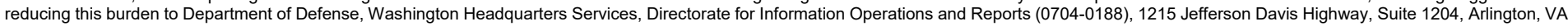

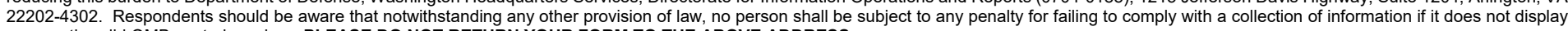
a currently valid OMB control number. PLEASE DO NOT RETURN YOUR FORM TO THE ABOVE ADDRESS.
1. REPORT DATE (DD-MM-YYYY)
2. REPORT TYPE
3. DATES COVERED (From - To)

July 2019

Final report

\section{TITLE AND SUBTITLE}

Investigation of Sand Boils near Ware, IL, Middle Mississippi River, Preston Levee District

5a. CONTRACT NUMBER

5b. GRANT NUMBER

5c. PROGRAM ELEMENT NUMBER

\section{AUTHORS}

Julie R. Kelley, Kevin B. Parkman, Ryan C. Strange,

Benjamin R. Breland, Joseph B. Dunbar, and

Maureen K. Corcoran

5d. PROJECT NUMBER

5e. TASK NUMBER

5f. WORK UNIT NUMBER

$4 \mathrm{~J} 213 \mathrm{~B}$

\section{PERFORMING ORGANIZATION NAME(S) AND ADDRESS(ES)}

8. PERFORMING ORGANIZATION REPORT NUMBER

U.S. Army Engineer Research and Development Center

Geotechnical and Structures Laboratory

ERDC/GSL TR-19-36

3909 Halls Ferry Road

Vicksburg, MS 39180-6199

\section{SPONSORING / MONITORING AGENCY NAME(S) AND ADDRESS(ES)}

10. SPONSOR/MONITOR'S ACRONYM(S)

U.S. Army Corps of Engineers

Washington, DC 20314-1000

11. SPONSOR/MONITOR'S REPORT NUMBER(S)

\section{DISTRIBUTION / AVAILABILITY STATEMENT}

Approved for public release; distribution is unlimited.

\section{SUPPLEMENTARY NOTES}

\section{ABSTRACT}

During flooding in 2011, 2013, and 2016 on the Middle Mississippi River between St. Louis and Cape Girardeau, MO, high-energy sand boils developed at the landside levee toe. These recent floods varied from moderate to major events but were well below the design flowline for the levees. This report documents a case study of internal erosion at a levee site in southern Illinois near the town of Ware, which is located in the Preston Drainage and Levee District. Site specific geotechnical data from the Ware site were used to identify parameters, such as top stratum thickness, Unified Soil Classification System (USCS) soil types, engineering properties, geologic depositional environments, stratigraphy, and hydraulic gradients that cause seepage and poor levee performance. An underlying assumption for this study was that sand boils discovered at the Ware site after the flooding in 2013 were formed during a single flood event. However, sand boils are typically associated with chronic seepage related to underlying site geology, levee orientation with the geology, and blocked exit conditions. Thus, seepage problems tend to progress over time in terms of their severity and response to medium to large flood events.

\section{SUBJECT TERMS}

2011 Flood, 2013 Flood, 2016 Flood, Internal erosion, Sand boils, Levee failure mechanism, Engineering geology, Geomorphology, Middle Mississippi River

\begin{tabular}{|l|l|l|}
\hline a. REPORT & b. ABSTRACT & c. THIS PAGE \\
UNCLASSIFIED & UNCLASSIFIED & UNCLASSIFIED \\
\hline
\end{tabular}

\section{SECURITY CLASSIFICATION OF:}

Seepage, Levees, Alluvial plains, Mississippi River-Flood control Geology-Mississippi River Valley
17. LIMITATION OF ABSTRACT

\section{NUMBER OF PAGES}

227 19a. NAME OF RESPONSIBLE PERSON Maureen Corcoran

19b. TELEPHONE NUMBER (include area code) 601-634-3334 